\title{
Biedermann Zsuzsánna: \\ Genocídium és destabilizáció az afrikai Nagy Tavak régióban - Ajánlások a megelőzésre
}




\title{
Nemzetközi Tanulmányok Intézet
}

\author{
Témavezetö: \\ Kardosné Dr. Kaponyi Erzsébet \\ egyetemi tanár
}

A Bíráló Bizottság névsora:

(C) Biedermann Zsuzsánna 


\section{Budapesti Corvinus Egyetem \\ Nemzetközi Kapcsolatok Multidiszciplináris Doktori Iskola}

Biedermann Zsuzsánna:

Genocídium és destabilizáció az afrikai Nagy Tavak régióban - Ajánlások a megelőzésre

Ph.D. értekezés

Budapest, 2013 
Köszönetnyilvánítás

Ez a dolgozat soha nem készülhetett volna el tanáraim, családom és barátaim segítsége nélkül. A továbbiakban a teljesség igénye nélkül szeretném külön kiemelni néhányukat. Elsőként szeretném megköszönni témavezetőm, Kardosné dr. Kaponyi Erzsébet munkáját. Minden konzultáció alkalmával újra és újra hasznos tanácsokkal és ötletekkel látott el. Kedvessége és lelkiismeretessége átsegített a dolgozatírás legnehezebb szakaszain.

Szeretném megköszönni Édesanyámnak és Édesapámnak, hogy megteremtette a feltételeket számomra ahhoz, hogy doktori tanulmányokat folytassak. Édesanyámnak, hogy számtalanszor elolvasta írásaimat és segítő megjegyzésekkel látott el.

Doktori tanulmányaim kezdeti szakaszában sokat segített Dr. Matus János, aki a téma iránti lelkesedésemet segített első angol nyelvü publikációmra váltani. Szeretném megköszönni a Nemzetközi Kapcsolatok Doktori Iskola vezetöjének, Dr. Rostoványi Zsoltnak, valamint a Világgazdasági alprogram vezetőjének, Dr. Blahó Andrásnak, hogy lehetővé tették részvételemet több külföldi konferencián és képzésen.

A dolgozatírás során számtalan alkalommal volt lehetőségem eszmét cserélni a Budapesti Központ a Népirtás és Tömeges Atrocitások Nemzetközi Megelőzéséért szakértőivel, többek között Dr. Enzo Maria Le Fevre Cervini, Dr. Tatár György, Dr. Ashad Sentongo is hozzájárult a dolgozatban szereplő hipotézisek és ajánlások végső formába öntéséhez.

Külön köszönet illeti a disszertáció tervezetének bírálóit, Dr. Csapó Zsuzsannát és Dr. Hoffmann Tamást, akik kritikai megjegyzéseikkel, iránymutatásukkal új irányba terelték eredeti elképzeléseimet, és hozzájárultak ahhoz, hogy választott témámat több szempontból és más megvilágításban is lássam.

Köszönöm az MTA KRTK Világgazdasági Intézetben dolgozó kollégáimnak támogatásukat, megértésüket.

Orosz Ágnes és Kovács Olivér felbecsülhetetlen értékü segítséget nyújtottak a disszertáció és a tézisfüzetek formázásának egységesítésében. Végül, de nem utolsósorban köszönöm évfolyamtársamnak, Illés Zoltánnak, hogy átolvasta a Szudánnal kapcsolatos részeket. 


\section{Tartalomjegyzék}

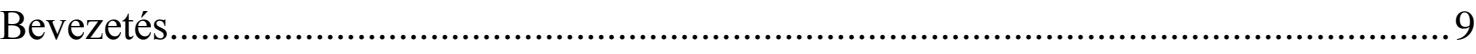

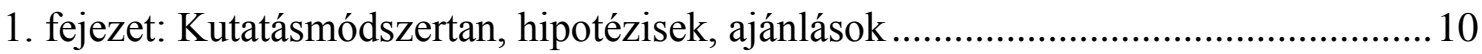

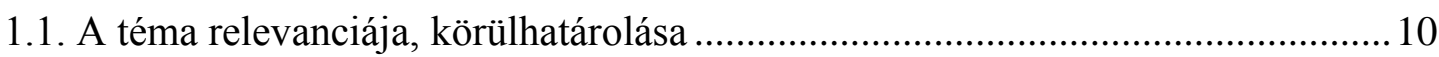

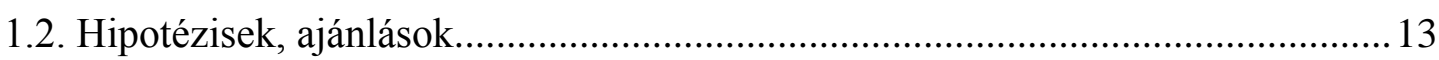

1.3. A kutatás forrásainak áttekintése …………………………………………........ 17

2. fejezet: A genocídium fogalmának értelmezése ....................................................... 21

2.1. A genocídium-fogalom eredete, nemzetközi jogi szabályozása .............................21

2.2. Az Egyezmény felülvizsgálatára irányuló kísérletek.............................................24

2.3. Az Egyezmény alkalmazása a gyakorlatban ........................................................2

2.4. A genocídium fogalmának elemei az Egyezményben, és az ezzel kapcsolatos

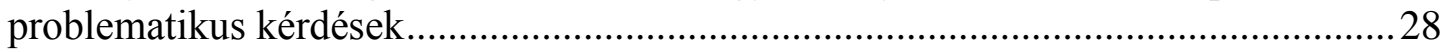

2.5. A genocídium fogalmának alternatív tudományos értelmezései ........................... 32

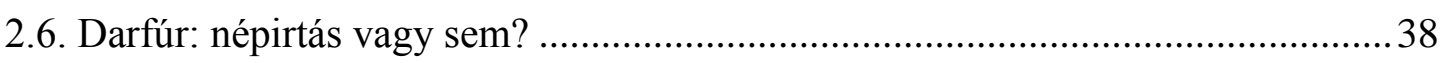

2.7. A népirtás elkülönítése más, hasonló jellegü büncselekményektől ....................... 41

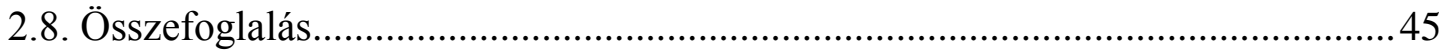

2.9. Javaslat a Genocídium-egyezmény módosítására ................................................4 46

3. fejezet: A népirtás megelőzésének nehézségei ..........................................................4

3.1. A megelőzés gyakorlati nehézségei ................................................................. 49

3.2. A genocídium kiváltó okai, előjelei, és szerepük a megelőzésben ........................52

3.3. Az előjelek értékelése, megelőzés, korai figyelmeztetés az ENSZ rendszerében58

3.3.1. A népirtás-megelőzési különleges tanácsadó és a védelem felelősségére koncentráló különleges megbízott hivatala ................................................................. 60

3.3.2. Emberi Jogi Tanács

3.3.3. A Nemzetközi Bíróság, az Emberi Jogi és Menekültügyi Főbiztosság, valamint egyéb releváns szervek.

3.3.4. Mi az oka a megelőzés sikertelenségének?

3.4. Az előjelek értékelése az ENSZ rendszerén kívül, regionális és civil szervezetek szerepe a megelőzésben . .67

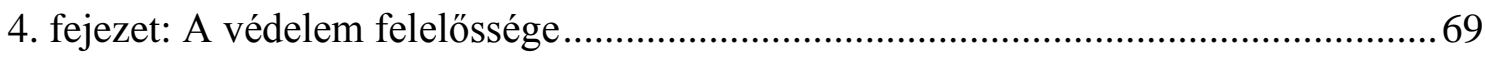

4.1. Az elv kialakulása és nemzetközi jogi elfogadottságának alakulása ....................70

4.2. A védelem felelősségének gyakorlati alkalmazása Líbiában................................78

4.3. Szíria: a védelem felelősségének kudarca? ……………………………………..... 82

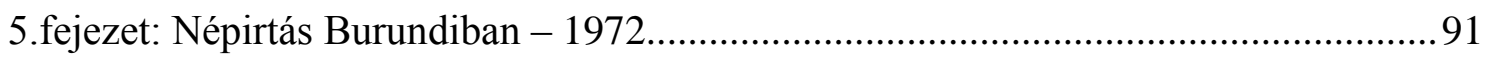

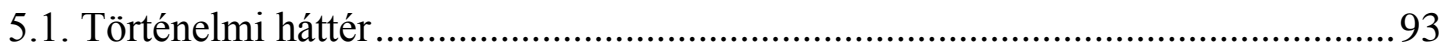

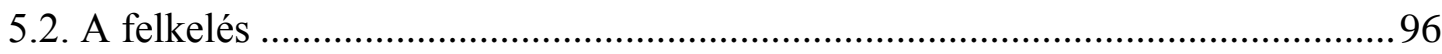

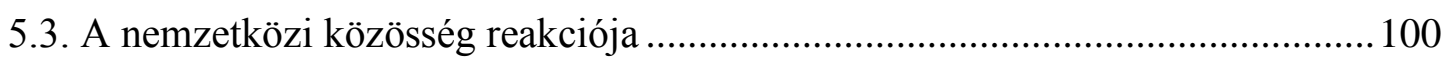

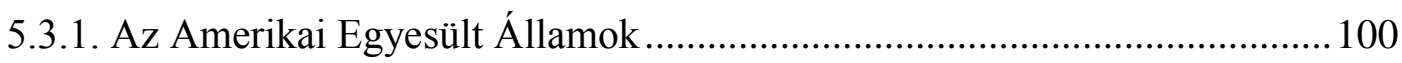




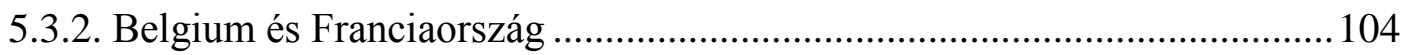

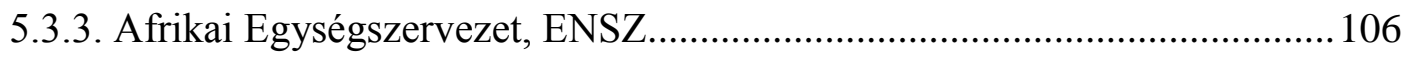

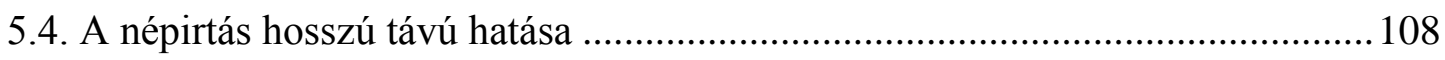

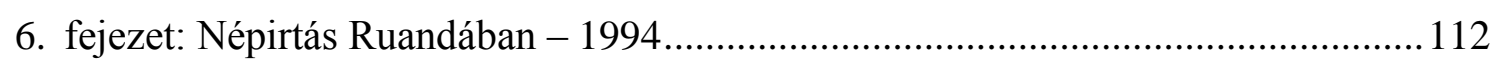

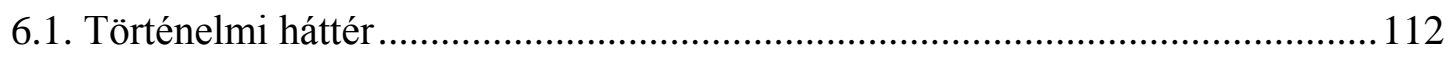

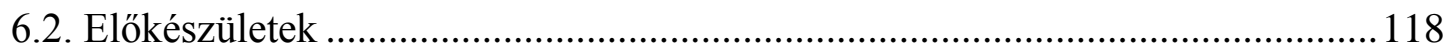

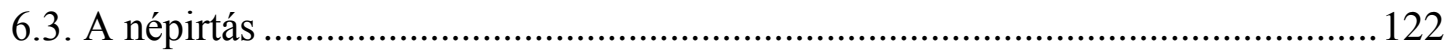

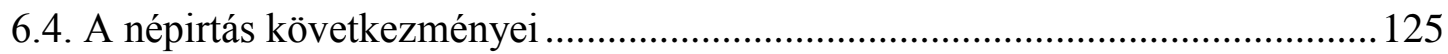

6.5. A nemzetközi közösség reakciója ................................................................ 129

6.5.1. ENSZ: A békefenntartás történetének egyik legsúlyosabb kudarca ........... 129

6.5.2. Afrikai Egységszervezet: a szolidaritás határai........................................ 135

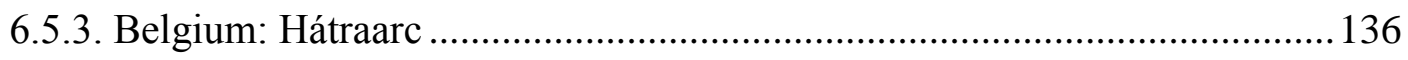

6.5.4. Franciaország: a Fashoda-szindróma hatása .............................................. 138

6.5.5. Amerikai Egyesült Államok: Szomália árnyéka ........................................ 143

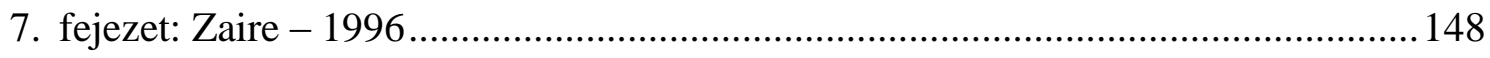

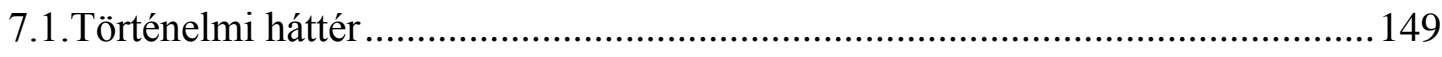

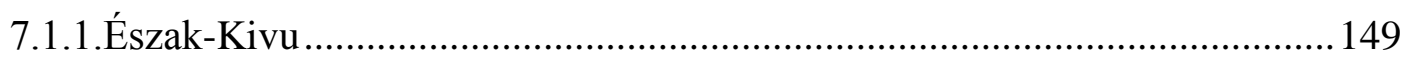

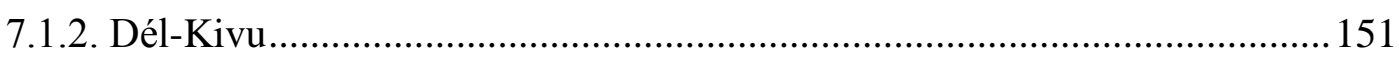

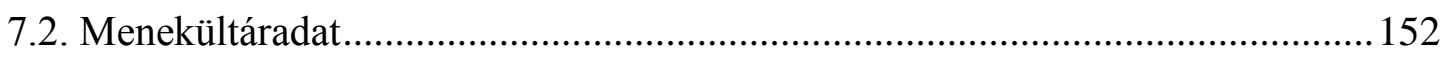

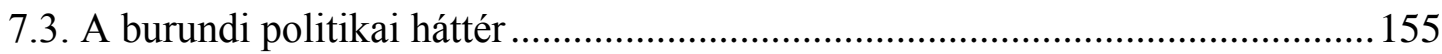

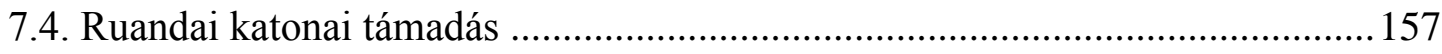

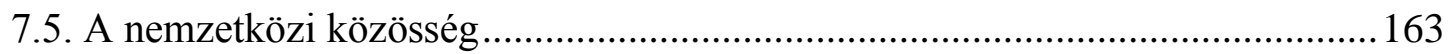

7.6. A beavatkozás mellett és ellen: Belgium, Franciaország és az USA álláspontja

7.7. A nemzetközi misszió ötletének körvonalazódása, és megvalósulásának kudarca

7.8. Nemzetközi reakció a 2010-es ENSZ-jelentésre................................................. 170

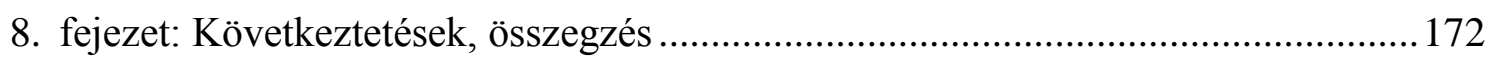

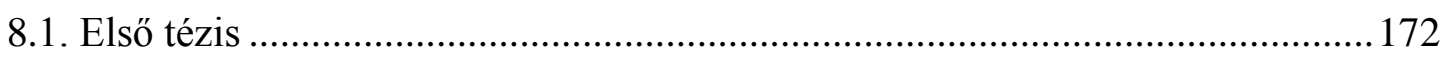

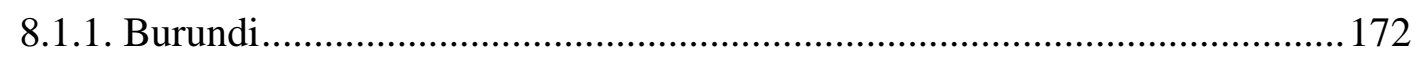

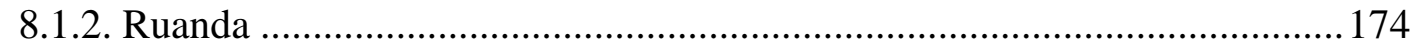

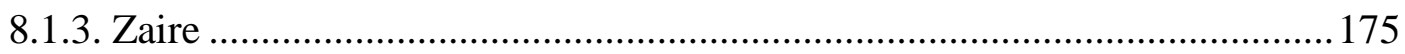

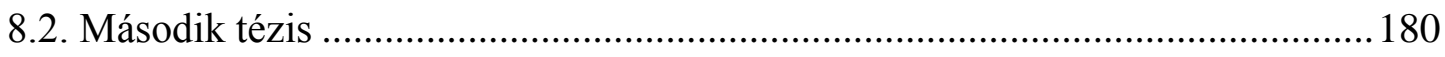

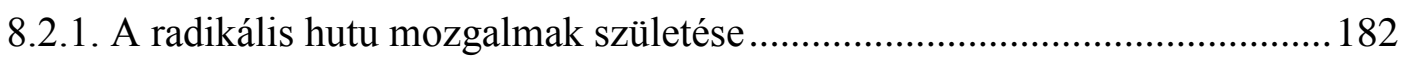

8.2.2. A tutszi menekültek militarizálódása Ugandában .................................... 182

8.2.3. A ruandai és burundi radikális hutu menekültek szövetségre lépnek Kivuban

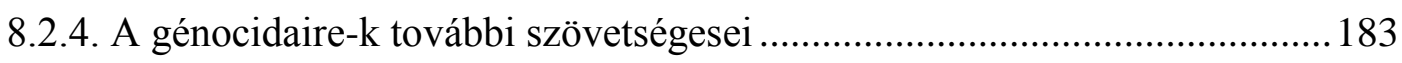




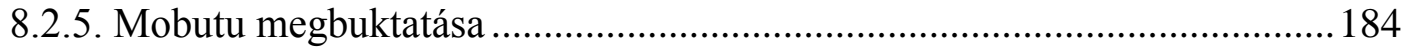

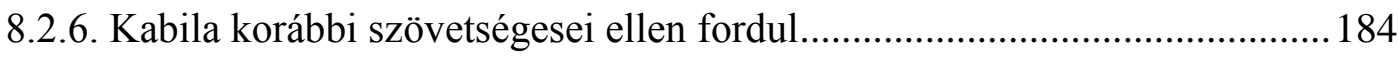

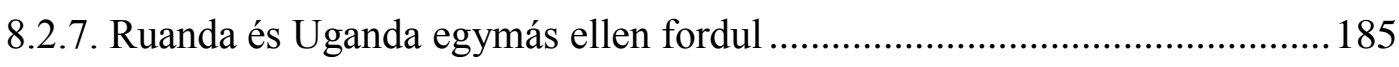

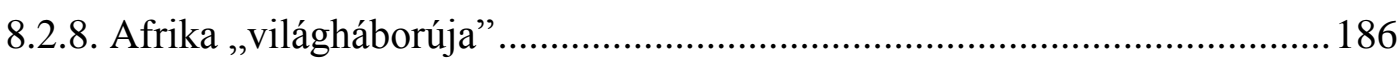

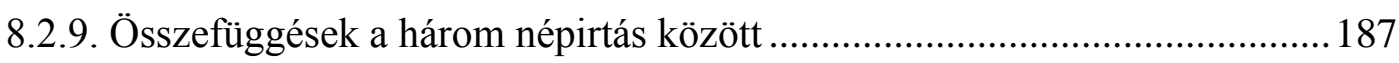

8.3. Ajánlások a hatékony megelőzésért ..................................................................190

8.3.1. Regionális megelőzés az afrikai Nagy Tavak régióban ................................ 191

8.3.1. Magyarország szerepe a népirtás-megelőzésben ..........................................196

8.3.2. A Genocídium-egyezmény előírásai a megelőzés és felelősségre vonás tekintetében, javaslat ellenőrző szerv létrehozására................................................ 199

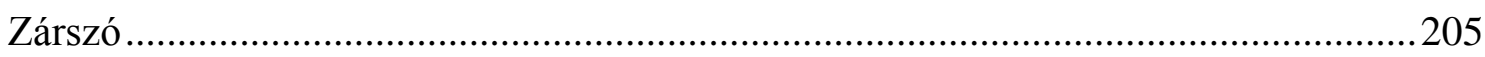

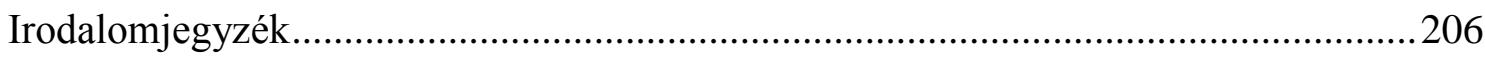

\section{Ábrajegyzék}

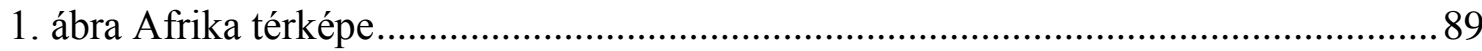

2. ábra Az afrikai Nagy Tavak régió ..........................................................................99

3. ábra Burundi térképe ........................................................................................ 91

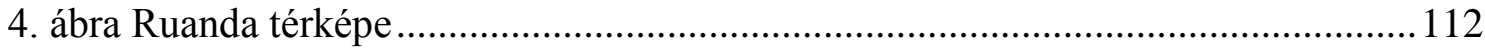

5. ábra A Kongói Demokratikus Köztársaság térképe ................................................... 148

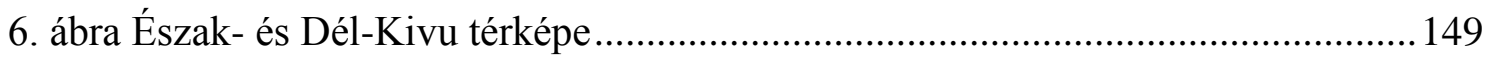

7. ábra A menekülttáborokból szétkergetett menekültek útvonala (DRC) ..................... 160

8. ábra A genocídium és a menekültkérdés összefüggésében kialakuló konfliktusok.. 180

9. ábra Ruandai menekültek Zaire felé tartanak........................................................... 181

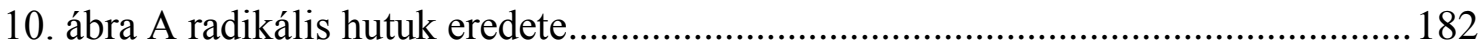

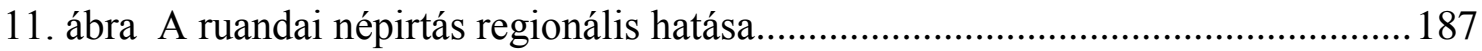




\section{Bevezetés}

Amikor a „genocídium” szót halljuk, hajlamosak vagyunk arra gondolni, hogy népirtás csak távoli helyeken fordulhat elö. Ilyenkor elfelejtjük, hogy a népirtás gyökerei, az előítéletel és a gyülölködés, minden társadalomban jelen vannak. Általában széles körben elterjedtek az olyan nézetek, amelyek más embercsoportokat veszélyesnek vagy károsnak tartanak. A legtöbb ország mégsem népirtás útján oldja meg a szociális feszültségeket, és nem lép a tömeges erőszak útjára, hacsak a politikai vezetők nem használják ki és fokozzák fel a társadalom látens indulatait.

Mielőtt azt gondolnánk, hogy a népirtás más népek problémája, szeretném hangsúlyozni, hogy a huszadik századot joggal tartják a népirtások évszázadának, hiszen a legtöbb áldozatot nem az országok közötti háborúk szedték. Többen haltak meg szervezett emberölési hullámok keretében, amikor saját társadalmuk tagjai (sok esetben korábbi szomszédaik) fordultak ellenük. A népirtások egyúttal jelentős biztonsági kockázatot is jelentenek, hiszen a tovagyürüző hatások miatt regionális instabilitást okozhatnak. A probléma tehát súlyos és aktuális.

A népirtások nemzetközi biztonsági kockázatát azonban alábecsülik, és megelőzésükre nem helyeznek kellö hangsúlyt.

A disszertáció az afrikai Nagy Tavak régió három országában (Burundi, Ruanda, Zaire) lezajlott népirtások részletes elemzésére vállalkozik, különös tekintettel arra, hogy a genocídiumokat miért nem sikerült megakadályozni. A dolgozat összefüggéseket tár fel a disszertációban tárgyalt esettanulmányok között, rámutatva a népirtások regionális és globális biztonsági kockázataira.

A disszertáció másik vonulata útmutatást tartalmaz: a Genocídium-egyezmény részletes vizsgálata után javaslatot tesz a genocídium meghatározásának módosítására és az esettanulmányok kapcsán ajánlásokat fogalmaz meg a nemzetközi közösség számára, amelyek elősegíthetik a hatékony megelőzést. Véleményem szerint egyrészt ki kellene bővíteni a genocídium jelenlegi definíciójában meghatározott védett csoportok szük körét, másrészt regionális fókuszpontok rendszerén, valamint a Genocídiumegyezmény által előírt megelőzési kötelezettség ellenőrzésére létrehozott kikényszerítő intézmény müködésén keresztül hatékonyabb nemzetközi megelőzési rendszert kellene létrehozni. 


\section{1. fejezet: Kutatásmódszertan, hipotézisek, ajánlások}

\subsection{A téma relevanciája, körülhatárolása}

A népirtás végigkísérte az emberiség történetét. Soha nem öltött azonban olyan szervezett formát, mint a huszadik században, amelyet számos szerző a népirtások évszázadának titulál (Ld. többek között ERIC D. WEITZ [2003] A Century of Genocide:Utopias of Race and Nation c.könyvét). ${ }^{1}$ Ennek oka egyrészt az áldozatok magas száma, valamint a megdöbbentő szervezettség és gépesítettség.

A második világháború végén úgy tünt, a nemzetközi közösség elszánta magát arra, hogy megelőzze a népirtásokat: 1948-ban az ENSZ elfogadta A Népirtás Büntettének Megelőzéséről és Megbüntetéséről Szóló Egyezményt (a továbbiakban:. Genocídiumegyezmény vagy Egyezmény). Az ENSZ Közgyülése (amely akkor 56 államot jelentett) megfogadta, hogy soha többé nem fordulhat elö, ami a második világháború során megtörtént.

Azóta bebizonyosodott, hogy a holokauszt korántsem jelentette a népirtások végét. A nemzetközi közösség a Genocídium-egyezmény aláírása óta, az elmúlt több mint hatvan évben újra és újra tehetetlenül nézte végig, ahogy népirtások zajlanak le Indonéziában, Bangladesben, Kambodzsában, Burundiban, Guatemalában, Boszniában és még számos egyéb helyen. Egyesek azzal indokolják a nemzetközi közösség tehetetlenségét, hogy a genocídium meghatározása nem egyértelmü, sok a nehezen besorolható eset. Mások azzal magyarázzák a megelőzés sikertelenségét, hogy a megelőzés miatti beavatkozás szabályai a mai napig sem világosak a nemzetközi jogban. ${ }^{2}$ Bármi legyen is az ok, a világ sorozatosan megszegte a „soha többé” ígéretét.

Napjainkban becslések szerint mintegy kétmilliárd embert érintenek közvetlenül vagy közvetve a népirtások, illetve azok következményei. ${ }^{3}$ A népirtások egyúttal jelentős biztonsági kockázatot is jelentenek, hiszen a tovagyürüző hatások miatt regionális instabilitást okozhatnak. A probléma tehát súlyos és aktuális.

\footnotetext{
${ }^{1}$ Weitz, Eric D.[2003]: A Century of Genocide: Utopias of Race and Nation, Princeton University Press, 2003

2 Lamb, Scott [2005]: Genocide Since 1945, Never Again? Spiegel Online International, http://www.spiegel.de /international/0,1518,338612,00.html, [2012.02.26.]

${ }^{3}$ Ez a becslés Daniel Jonah Goldhagentől származik, és vonatkozik áldozatokra, elkövetőkre, azok közeli és távoli rokonaira (Goldhagen, Daniel Jonah [2009]: Worse than war: Genocide, Eliminationism, and the Ongoing Assault on Humanity, PublicAffairs, New York), 273.old.
} 
Mi lehet az oka, hogy ennek ellenére számos népirtást nem sikerült megakadályozni a Genocídium-egyezmény elfogadása óta? Vajon tanulhatunk az eddig megtörtént esetekből? Összefüggenek-e a disszertációban tárgyalt esetek? Ha összehasonlítunk különböző genocídiumokat, felfedezhetünk közös jellemzőket? A közös vonások feltárásával megelőzhetőek-e a jövő népirtásai? A disszertáció szerzőjének határozott véleménye szerint igen, ezért is választotta ezt a Magyarországon kevéssé tárgyalt témát.

A dolgozat összefüggéseket tár fel a disszertációban tárgyalt esettanulmányok között, rámutatva a népirtások regionális és globális biztonsági kockázataira. A disszertáció másik vonulata útmutatást tartalmaz: a Genocídium-egyezmény részletes vizsgálata után javaslatot tesz a genocídium fogalmának módosítására és az esettanulmányok kapcsán ajánlásokat fogalmaz meg a nemzetközi közösség számára, amelyek elősegíthetik a hatékony megelözést.

A dolgozatban először a népirtás definícióját tárgyalom részletesen, és a meghatározással kapcsolatos problémás kérdések vizsgálata után javaslatot teszek a Genocídium-egyezményben foglaltak módosítására.

A dolgozat következő egységében a népirtások gyakorlati megelőzésének kérdését veszem górcső alá. Ennek keretében megvizsgálom a megelőzés rendelkezésre álló eszköztárát, azaz a megelőzéssel foglalkozó nemzetközi szervezetrendszert. A huszonegyedik század első népirtásának, a szudáni esetnek az okait és jellegzetességeit vizsgálva egyértelmü, hogy a nemzetközi közösség prevenciós mechanizmusai jelenleg nem elég hatékonyak.

A dolgozatban részletesen szólok a megelőzés és az előrejelzés nehézségeiről, a komparatív népirtástudomány által megállapított előjelekről és hajlamosító tényezőkről. Kifejtem a népirtás megelőzésével kapcsolatos legújabb nemzetközi fejleményeket, többek között a 2005 után előtérbe került „responsibility to protect”, azaz védelem felelőssége elvét. Elemző jelleggel tárgyalom a rendelkezésre álló intézményi kapacitásokat nemzetközi szinten (ENSZ megelőzéssel foglalkozó szervei, nemkormányzati szervek tevékenysége), röviden foglalkozom az Európai Unió megelőzésben betöltött jelenlegi szerepével.

A megelőzés nehézségeit és múltbeli kudarcait, valamint ajánlásaimat a hatékonyabb megelőzés érdekében három esettanulmány segítségével ábrázolom. Burundi, Ruanda és Zaire (később Kongói Demokratikus Köztársaság) népirtásainak 
elemző bemutatásával nem csak az egyes esetek jellegzetességeit világítom meg, hanem az egész afrikai Nagy Tavak Régió népirtásokhoz kapcsolódó dinamikáját is.

A Burundiban 1972-ben történt népirtás, amely mintegy 200-300.000 hutu áldozatot szedett, rendkívül fontos szerepet játszott a régióban zajló folyamatok alakulásában. Huszonkét évvel később Ruandában a hutu elit a hatalom megtartása érdekében súlyos indulatokat gerjesztett a társadalomban a tutszi kisebbség és a velük tárgyalni próbáló mérsékelt hutuk ellen, amely népirtáshoz vezetett. A genocídium miatt több mint félmillióan vesztették életüket és menekültek százezrei indultak a szomszédos országokba. A legtöbb menekültet befogadó, politikailag instabil Zaire keleti, Ruandával határos része ,ideális” bázisa lett a ruandai kormány ellen harcoló, megbuktatott népirtó rezsim vezetőinek, akik a menekültekkel együtt beszivárogtak a menekülttáborokba. 1996-ban Ruanda megtámadta a zairei menekülttáborokat, aminek következtében közel 200.000 ember veszett oda, és megbukott a hírhedt zairei diktátor, Mobutu. Zairéban a ruandai segítséggel hatalomra kerülő Kabila hamar korábbi szövetségese ellen fordult, és az egész afrikai Nagy Tavak régiót, valamint a környező országokat is érintő háború kezdődött, amelyet sok szakértő „Afrika világháborújának” nevez.

A dolgozat részletesen kitér arra, hogy az egyes esetekben miért nem voltak sikeresek a megelőzésre tett kísérletek, valamint tárgyalja a nemzetközi közösség, (különös tekintettel Belgiumra, Franciaországra, az Amerikai Egyesült Államokra, az Európai Unióra, valamint az Egyesült Nemzetek Szervezetére) reakcióit a genocídiumok folyamán és után.

Az esettanulmányok után rátérek a megelőzés nemzetközi intézményrendszerének ígéretes kezdeményezéseire. Az esettanulmányokhoz kapcsolódik az afrikai régió megelőző szervének, a Nagy Tavak régiójával foglalkozó nemzetközi konferenciának (International Conference on the Great Lakes Region) a müködése, amelyemet ismertetek.

Kiemelten tárgyalom a müködését 2012-ben megkezdő budapesti Népirtások és Tömeges Atrocitások Nemzetközi Megelözéséért Alapítvány (Foundation for the International Prevention of Genocide and Mass Atrocities) ${ }^{4}$ müködésének perspektíváit és ennek kapcsán Magyarország népirtás-megelőzésben betöltött jövőbeli aktív szerepét.

\footnotetext{
${ }^{4}$ www.genocideprevention.eu
} 


\subsection{Hipotézisek, ajánlások}

A dolgozat alapkérdése, hogy a népirtás megelőzhető-e, és amennyiben igen, akkor ehhez milyen változtatásokra van szükség a nemzetközi, regionális és az egyes országok nemzeti intézményrendszerében.

Esettanulmányok segítségével igyekszem feltárni, hogy miért fulladt többször is kudarcba a megelőzés a Genocídium-egyezmény hatályba lépése óta. Az esettanulmányok az afrikai Nagy Tavak országait veszik górcső alá, hiszen ez a térség a mai napig veszélyeztetett régiónak számít.

A dolgozat újdonsága, hogy a népirtásokat folyamatként ábrázolja, amelynek több pontján is lehetséges lenne az eseményeket eltéríteni irányuktól. Ha bekövetkezik a genocídium, akkor is gyakran elöfordul, hogy a nemzetközi közösség a közvetlen következményeket tüzoltás-jelleggel, az alapvető, atrocitásokhoz vezető feszültségekről leválasztva kezeli, és figyelmen kívül hagyja a népirtáshoz vezető alapvető okokat. Pedig ezek az okok gyakran még a korábbinál is súlyosabb formában jelentkeznek, és nem csak közvetlenül a népirtás utáni években (például az évtizedek múlva hazatérö menekültek miatt). Éppen ezért a népirtások megelőzéséhez komplex intézményrendszer kiépítésére van szükség. Különösen égető probléma a népirtásmegelőzés az afrikai Nagy Tavak országaiban.

A folyamatábrázolás azt is jelenti, hogy a rövid távú válságkezelést és a hosszabb távú béketeremtő eszközöket össze kell kapcsolni a megelőzés érdekében. Az elemzés során számba veszem a már rendelkezésére álló eszközöket is, és azok szisztematikusabb és összehangoltabb használatára teszek javaslatot.

A térség nehézségeit összefüggéseiben igyekszem tárgyalni: részletesen kifejtem, hogy a hutuk és tutszik közötti etnikai feszültségek hogyan vezettek a közvélemény által kevéssé ismert 1972-es népirtáshoz Burundiban. Az erőszak menekülthullámot indított el a térségben, és jelentős szerepe volt az 1994-es ruandai események alakulásában. Az újabb genocídium és menekültáradat vezetett többek között a Kongói Demokratikus Köztársaság területén évekig húzódó háborúhoz.

Szintén ehhez a térséghez kapcsolódik a huszonegyedik század első népirtása Szudánban. A nemzetközi közösség sokáig megosztott volt abban a tekintetben, hogy népirtásnak minősíthetőek-e a Darfúrban zajló események, ez a kettősség pedig jól mutatja a népirtás definíciójával kapcsolatban felmerülő kérdéseket, amelyeket a 
dolgozatban szintén kimerítően vizsgálok. ${ }^{5}$ Az esettanulmányok arra is rávilágítanak, hogy a fogalom világos, objektív körülhatárolása mind a tudományos, mind a hétköznapi életben feltétlenül szükséges lenne a hatékony megelőzéshez.

Dolgozatomban a deduktív módszert alkalmazom: a kutatási szakirodalom alapján megfogalmazott hipotézisekből indulok ki, ezek igazolására gyüjtök adatokat, esettanulmányokat, és vizsgálok meg különféle szempontokat, majd döntök a hipotéziseim elfogadásáról vagy elvetéséről.

A hipotéziseim a következők:

\section{A nemzetközi közösségnek elemi érdeke lenne a genocídiumok} megakadályozása, mert a népirtások nyomán kialakult menekültáradat súlyos instabilitást okozhat nemcsak belföldön és a szomszédos országokban, hanem a környező régióban is, a tovagyűrűző (spillover) ${ }^{6}$ hatások miatt pedig negatívan befolyásolhatja a nemzetközi biztonságot.

Számos szakértő foglalkozik a népirtás kiváltó okaival és következményeivel, és sokan írnak a szünni nem akaró menekülthullámok hatásairól Afrikában, de a két jelenséget csak ritkán kapcsolják össze. Márpedig egy kezdődő népirtás legbiztosabb jele a menekültáradat megindulása a szomszéd országokba. Előfordulhat, hogy a menekültek csak évtizedek múlva térhetnek vissza származási helyükre, ahol időközben már kisajátították földjeiket és egyéb tulajdonukat. Ráadásul a több százezer menekült a szomszédos országokban is fokozza a feszültséget. A dolgozatban a népirtásmenekültáradat-tovagyürüző problémák ördögi körét igyekszem részletesebben kibontani, hangsúlyozva a konfliktusok biztonságpolitikai kockázatát.

\footnotetext{
5 Mahmood Mamdani 2007-ben "The Politics of Naming Genocide: Genocide, Civil War, Insurgency (London Review of Books, Vol. 29 No. 5 , 8 March 2007)címü cikkében arról ír, hogy inkább felkelésnek és az arra válaszul adott ellencsapásnak tartja a darfúri konfliktust. Alex de Waal, aki részt vett a szudáni béketárgyalásokon, szintén hasonló álláspontot képviselt egy Darfúrról rendezett vitában 2007-ben. (Dueling Over Darfur, Nov 7, 2007. From Newsweek: http://www.thedailybeast.com /newsweek/2007/11/07/dueling-over-darfur.html [2011.09.12.] ) A Nemzetközi Büntetőbíróság Omar AlBashir ellen kiadott 2010. júliusi elfogatóparancsa ellenben már nevesítette a népirtás vádját.( Second Warrant of Arrest for Omar Hassan Ahmad Al Bashir, No. ICC-02/05-01/09. 12 July 2010, http://www.icc-cpi.int/iccdocs/doc/doc907140.pdf, [2011.09.13.])

${ }^{6}$ Spill overről- tovaterjedésről, tovagyürüzésről - akkor beszélhetünk, amikor egy meghatározott célra irányuló cselekvés olyan helyzetet hoz létre, hogy az eredeti célt csak további lépésekkel lehet biztosítani, amelyek azután ismét további lépéseket szükségessé tevő újabb helyzethez, jelen esetben újabb konfliktushoz vezetnek, és így tovább.
} 
A ruandai és burundi esettanulmányok segítségével bebizonyítom, hogy hogyan járultak hozzá az egymást követő népirtások az egész régió destabilizálódásához, az újabb és újabb menekülthullámok pedig az első és második kongói háborúhoz.

2. A genocídium fogalma napjainkban továbbra sem egyértelmú, mivel az elsődleges jogforrás, A Népirtás Megelőzéséről és Megbüntetéséről Szóló Egyezmény szövege is számos kérdést vet fel. A fogalom világos, objektív körülhatárolása mind a tudományos, mind a hétköznapi életben feltétlenül szükséges a hatékony megelözéshez. A hatékony megelözéshez álláspontom szerint a védett csoportok körét bővíteni kellene.

Az Egyezmény szövege túlságosan restriktív, hiszen többek között a politikai csoportok nem tartoznak a védett csoportok közé. Az 1948 utáni, genocídiumként meghatározott esetek között nagyon kevés az Egyezmény definíciója szerinti népirtás. A legtöbb esetben népirtás és politicídium ${ }^{7}$ (politikai csoportok ellen elkövetett atrocitások), vagy „,csak” politicídium zajlott.

Az alapcselekmények tekintetében az Egyezményben „a csoport tagjainak súlyos testi vagy lelki sérelem okozása" kategória meglehetősen szubjektív és széles körben értelmezhetö.

A dolgozatban kísérletet teszek a fogalom egyértelmüsítésére (a napjainkban általánosan elfogadott jogi értelmezésre), ehhez felhasználom a Nemzetközi Büntetőbíróság (ICC), valamint a Volt-Jugoszláv (ICTY) és Ruandai nemzetközi Büntetőtörvényszékek (ICTR) döntéseit, jogértelmezését. Az Egyezmény definíciójának és a vonatkozó joganyagnak a részletes vizsgálata után javaslatot teszek az Egyezmény szövegének módosítására.

Az esettanulmányok, valamint a napjainkban a népirtás-megelőzéssel foglalkozó nemzetközi intézményrendszer elemző vizsgálata alapján a disszertáció végén ajánlásokat is megfogalmazok:

1. A Genocídium-egyezményből fakadó kötelezettségek betartása érdekében kikényszerítő intézményrendszer kialakítására van szükség. A tagországok

\footnotetext{
7 Ezt a fogalmat Barbara Harff alkotta, részletesebben kifejtésre kerül a népirtásokra hajlamosító tényezőkről és a népirtások előjeleiről szóló részben
} 


\section{független szakértőiből álló testület feladata a részes államok szerződésből eredő kötelezettségeinek bizonyos, meghatározott időközönkénti felülvizsgálata lenne.}

Az ENSZ emberi jogi egyezményeinek hatékony végrehajtása érdekében a tagországok általában független szakértőkből álló testületeket állítanak fel. Ezek a testületek a részes államoknak az egyezményből eredő nemzetközi jogi kötelezettségeit figyelemmel kísérik. ${ }^{8}$ Például az ENSZ A kínzás és más kegyetlen, embertelen vagy megalázó büntetések vagy bánásmódok elleni egyezménye által elöírt kötelezettségek betartására az egyezmény létrehozta az ENSZ Kínzás Elleni Bizottságát. ${ }^{9}$ Ezen bizottság jelentéstételi kötelezettségén kívül 2006-tól a kiegészítő jegyzőkönyv újabb ellenőrző mechanizmusokat hozott létre: az ENSZ mellett müködö, független szakértőkből álló Megelőzési Albizottságot és a tagállamok által müködtetett „,nemzeti megelőző mechanizmusokat". ${ }^{10}$ A Genocídium-egyezmény azonban semmiféle konkrét előírást nem tartalmaz a végrehajtás ellenőrzésére vonatkozóan, arra viszont kötelezi a részes államokat, hogy tegyenek lépéseket a megelőzés és a felelősségre vonás érdekében.

A disszertációban javaslatot teszek egy független szakértőkből álló testület létrehozására, amely véleményem szerint sokat lendítene a népirtás-megelőzés ügyén. A Népirtás-megelőzési Bizottság működését az ENSZ tagállamok emberi jogi helyzetét értékelő egyetemes időszakos felülvizsgálat (UPR) mintájára képzelem el.

\section{A népirtások hatékony megelőzéséhez regionális „fókuszpontokra" van szükség a világ különböző pontjain, amelyek feladata az információgyưjtés és értékelés mellett ajánlások készítése lenne a döntéshozók számára.}

A népirtás és tömeges emberi jogi jogsértések területén a kockázatok kezelésének és a veszélyek elhárításának egyik akadálya az intézményi kapacitás hiánya. A disszertációban részletes elemzésnek vetem alá a létező intézményrendszert és az

\footnotetext{
${ }^{8}$ Haraszti Margit Katalin[2008]: A kínzás és az embertelen vagy megalázó bánásmód és büntetések tilalma az ENSZ és az Európa Tanács legfontosabb dokumentumaiban, valamint az állampolgári jogok országgyülési biztosának tevékenységében. ACTA HUMANA 19. évfolyam, 2008. 3. szám, 51.oldal ${ }^{9}$ Convention against Torture and Other Cruel, Inhuman or Degrading Treatment or Punishment Part II, Articles 17-24. http://www2.ohchr.org/english/law/cat.htm,[2011.09.20.]

${ }^{10}$ Optional Protocol to the Convention against Torture and other Cruel, Inhuman or Degrading Treatment or Punishment. Part II-III-IV., Articles 5-23. http://www2.ohchr.org/english/law/cat-one.htm, [2011.09.20.]
} 
esettanulmányok segítségével bizonyítom, hogy a megelőzés sokkal hatékonyabb lenne, ha regionális „fókuszpontok” jönnének létre.

Ezen intézmények feladata az lenne, hogy információt gyüjtsenek és értékeljenek, folyamatosan ellenőrizzék az elmérgesedéssel fenyegető helyzeteket, felismerjék a genocídium és tömeges emberi jogi jogsértések bekövetkeztének kockázatát, valamint készítsenek megvalósítható alternatívákat nyújtó ajánlásokat, és nyomást gyakoroljanak a döntéshozókra. A hatékony megelözés kulcskérdése, hogy sikerüljön megteremteni a cselekvéshez szükséges politikai akaratot.

\subsection{A kutatás forrásainak áttekintése}

A dolgozat alapvetően háromféle forrásra támaszkodik. Az egyik legfontosabb forráscsoport a vonatkozó szakirodalom. A népirtások közvetlen és közvetett hatásairól számos szerző értekezik. HAGENGIMANA ${ }^{11}$ [2001], SCHIRALDI ${ }^{12}$ [2000] és KALAYJIAN ${ }^{13}$ [1996] a népirtások áldozatokra és a helyi lakosságra gyakorolt hatásával foglalkozik, míg a regionális stabilitás kérdéseire és a genocídiumok nemzetközi következményeire fókuszál többek között HARFF és GURR ${ }^{14}$ [1996], JONASSOHN és BJÖRNSON ${ }^{15}$ [1998], valamint PRUNIER ${ }^{16}$ [2009] munkássága. A népirtások megelőzésével kapcsolatban szintén bőséges szakirodalom áll rendelkezésre: többek között HAMBURG ${ }^{17}$ [2010], POWER $^{18}$ [2003], CUSHMAN ${ }^{19}$ [2003] és a téma korai szakértői közül KUPER ${ }^{20}$ [1985], valamint STAUB ${ }^{21}$ [1999] írásai relevánsak ebben a témakörben.

A Genocídium-egyezmény szövegének behatóbb vizsgálata többek között WILLIAM SCHABAS [2009] nevéhez füződik, aki terjedelmes könyvében a népirtás nemzetközi

11 Hagengimana, A. [2001]. After Genocide in Rwanda: Social and Psychological Consequences. http://instituteforthestudyofgenocide.org/oldsite/newsletters/25/athanse.html, [2011.10.25.],

${ }^{12}$ Schiraldi, G. R. [2000]. The post-traumatic stress disorder sourcebook. Los Angeles: Lowell House

${ }^{13}$ Kalayjian, A. S., Shahinian, S. P., Gergerian, E. L., \& Saraydarian, L. [1996]: Coping with Ottoman Turkish genocide: An exploration of the experience of Armenian survivors. Journal of Traumatic Stress, 9(1), 87-97.

${ }^{14}$ Barbara Harff, Ted Gurr[1994]: Ethnic conflict in World Politics, Westview Press

15 Jonassohn, Kurt and Karin Solveig Björnson[1998]: Genocide and Gross Human Rights Violations in Comparative Perspective., Transaction Publishers

${ }^{16}$ Prunier, Gérard [2009]: From Genocide to Continental War: The "Congolese" Conflict and the Crisis of Contemporary Africa, C. Hurst \& Co

${ }^{17}$ Hamburg, David [2010]: Preventing Genocide- Practical steps toward early detection and effective action, Paradigm Publishers

${ }^{18}$ Power, Samantha [2003]: A Problem From Hell, America and the Age of Genocide , HarperCollins, 2003

${ }^{19}$ Cushman, T.[2003]: Is Genocide Preventable? Some Theoretical Considerations, Journal of Genocide Research, vol. 5, no. 4, (December 2003), pp. 523-542.

${ }^{20}$ Kuper, Leo[1985]: The Prevention of Genocide, New Haven and London: Yale University Press

21 Staub, E.[1999]: The Origins and Prevention of Genocide, Mass Killing, and Other Collective Violence, Peace and Conflict: Journal of Peace Psychology, vol. 5, no. 4, pp. 303-336. 
jogban betöltött szerepét vizsgálta. Az Egyezmény végleges szövege politikai kompromisszumok eredménye, így elemzésekor érdemes az előzetes tárgyalások menetét is részletesebben megismerni: HIRAD ABTAHI és PAUla WeBB ${ }^{22}$ [2008] nemrégiben megjelent részletes munkája a szöveg kialakulásának időszakába enged bepillantást.

Nemzetközi jogi szempontból a népirtás koncepciójához szorosan kapcsolódik a 2005-ben elfogadott védelem felelőssége elv. A védelem felelősségével számos művében foglalkozik BELlAMY ${ }^{23}$ [2009], illetve MAJEKODUNMI és SMITH-HoHN ${ }^{24}$ [2008], valamint az elv gyakorlatba átültetését tárgyalja DAY és FREEMAN ${ }^{25}$ [2005], valamint HAMILTON ${ }^{26}$ [2006]. Megelőzés szempontjából kifejezetten Afrikára fókuszál MuRITHI és MPYISI $^{27}$ [2007], valamint FeINSTEIN ${ }^{28}$ [2007] több írása is. A burundiruandai események, valamint a Kongói Demokratikus Köztársaságban kirobbant háború és a szudáni népirtás összefüggéseinek feltárásával foglalkozik GÉRARD PRUNIER ${ }^{29}$ [1995] történész, valamint a magyar szerzők közül SZABÓ LORÁND[2008] ${ }^{30}$ és TARRÓSY IsTVÁN[2011]. ${ }^{31}$ A népirtások biztonságpolitikai aspektusait segítenek megérteni

\footnotetext{
${ }^{22}$ Abtahi, Hirad,Webb, Paula[2008]: The Genocide Convention: The Travaux Préparatoires Martinus Nijhoff Publishers

${ }^{23}$ Bellamy, A.[2009]: Responsibility to Protect: The Global Effort to End Mass Atrocities, Cambridge: Polity Press

Bellamy, A.[2010]:The Responsibility to Protect: Five Years On, Ethics and International Affairs, vol. 24, no. 2,

(2010), 143-169. old.

${ }^{24}$ Davis, R., Majekodunmi, B., Smith-Hohn, J.[2008]:Prevention of Genocide and Mass Atrocities and the Responsibility to Protect: Challenges for the UN and the International Community in the 21st Century The Responsibility to Protect Occasional Paper Series, International Peace Institute

${ }^{25}$ Day, G., \& Freeman, C.[2005]:Operationalizing the Responsibility to Protect - The Policekeeping Approach. Global Governance, no.11, 2005, 139-147.old.

${ }^{26}$ Hamilton, R.J.[2006]:The Responsibility to Protect: From Document to Doctrine - But What of Implementation?, Harvard Human Rights Journal, no.19, 289-297.old.

27 Murithi, T., \& Mpyisi, K. (eds.) [2007]:Conflict Prevention and the 'Responsibility to Protect' in Africa?, African Security Review vol 16, no. 3, September 2007

${ }^{28}$ Feinstein, L.[2007]:Darfur and Beyond: What Is Needed to Prevent Mass Atrocities", Council on Foreign Relations Special Report, no. 22, January 2007

${ }^{29}$ Prunier, Gérard [1995]:The Rwanda Crisis: History of a Genocide, Columbia University Press. Prunier, Gérard [2009]: Africa's World War: Congo, the Rwandan Genocide, and the Making of Continental Catastrophe, Oxford University Press, Prunier, Gérard [2006]: Did Somebody Say Genocide?: Gérard Prunier on Darfur, Harper's Magazine, August 2006, Prunier, Gérard [2002]: Sudan: irreconcilable differences, Le Monde diplomatique, December 2002, Prunier, Gérard [1989]: Les Ethnies ont une histoire (ed. with Jean-Pierre Chrétien), Paris : Karthala

${ }^{30}$ Szabó Loránd [2008]: Kongói Kaleidoszkóp 1998-2008. A hatalmi erõtér változásai. Külügyi Szemle, 2008. tél, 119-139. o.

31 Tarrósy István [2011]: Kelet-Afrika a fejlődés útján: A Kelet-afrikai Közösség és tagállamai közelebbről. Pécs: Publikon Kiadó
} 
BArry BuZAN [1998], ${ }^{32}$ MAtus JÁnos [2005] ${ }^{33}$ és Kondorosi Ferenc [2008] ${ }^{34}$ munkái.

A népirtás megelőzésének intézményesítéséröl értekezik többek között FREEMAN ${ }^{35}$ [1999], valamint VINCENT és LE FEVRE CERVINI ${ }^{36}$ [2008], illetve WoOCHER ${ }^{37}$ [2009].

Másodsorban, a dolgozat megírásához felhasználom a Genocídium-egyezmény eredeti szövegét, az ICTR és ICTY, valamint az ICC releváns bírói döntéseit, amelyek segítenek a fogalom aktuális értelmezésében. Felhasználom továbbá az ENSZ Közgyülés határozatait az esettanulmányok kapcsán: ezek segítségével részletesen megvizsgálom, hogy a közös politikai akarat hiánya mennyire volt meghatározó elem a nemzetközi megelőzés ismétlődő kudarcában. A megelőzés intézményesítésének legújabb fejleményeihez kapcsolódó dokumentumok is elemzésre kerülnek: a 2005-ben elfogadott védelem felelőssége közgyülési határozat, valamint többek között az ICGLR (Nagy Tavak Környékének Nemzetközi Konferenciája) népirtás-megelőzéssel kapcsolatos megállapodásai.

Harmadik forrásként a népirtásokkal foglalkozó egyes kutatócsoportok (pl. Cambodian Genocide Program, Yale University, Strassler Family Center for Holocaust and Genocide Studies, Clark University) anyagait is hasznosítva igyekszem levonni a következtetéseimet. A dolgozat célja, hogy az egyes tanulmányok, könyvek megállapításait, valamint a saját kutatásaimat párhuzamba állítsa az egyes nemzetközi szervezetek megállapításaival is (Médecins Sans Frontières, Amnesty International, Human Rights Watch).

A kutatás során multidiszciplináris megközelítést alkalmazok, azaz ötvözöm a nemzetközi politikaelmélet, a nemzetközi jog, a történelem és esetenként a biztonságpolitika tudományterületeit. Az elemzés párhuzamosan több síkon zajlik, amelyek szorosan összefonódnak: az összehasonlítás, a történeti elemzés és a megelőzésben tapasztalható hiátusok elemzésének módszerével. A kutatás elsősorban

\footnotetext{
${ }^{32}$ Buzan, Barry, Weaver, Ole, de Wilde, Jaap [1998]: Security: A New Framework for Analysis. (Lynne Rienner Publisher

${ }^{33}$ Matus János [2005]: A jövő árnyéka. Nemzetközi hatások biztonságunkra és jólétünkre. A Pesti Csoport Kiadó, Budapest

${ }^{34}$ Kondorosi Ferenc [2008]: A világ végveszélyben? A nemzetközi jog új kérdései, Budapest, Magyar Közlöny- és Lapkiadó

${ }^{35}$ Freeman, M.[1999]: The Role of Institution Building in the Prevention of Genocide, in Smith, R.W., (ed.): Genocide: Essays toward Understanding, Early-Warning and Prevention, New York: Association of Genocide Scholars

36 Vincent, M.; Le Fevre Cervini, E. [2008]: Preventing Genocide and Mass Atrocities: Our Responsibility to Prevent, Madariaga Report

37 Woocher, L.[2008]:Preventing Violent Conflict: Assessing Progress, Meeting Challenges. United States Institute of Peace, Special Report
} 
összehasonlító vizsgálatokat alkalmaz, midőn mások írásait, kutatási eredményeit veti össze egyrészt egymással, másrészt saját elgondolásokkal, kutatásokkal.

Nem az eddig megjelent szakirodalom kivonatát, recenzióját kívánom adni, hiszen - ahogyan erre korábban is utaltam - sok tanulmány foglalkozik a népirtással, és a megelőzéssel. Én arra teszek kísérletet, hogy a megvizsgáljam a népirtást mint folyamatot, annak minden előzményével és következményével együtt, melyhez viszont nélkülözhetetlen az egyes szakértők korábbi megállapításainak felhasználása. A hiányosságok felmérése után javaslatokat teszek a népirtás-megelözés jelenlegi intézményrendszerének átalakítására, új intézmények felállítására.

Több jól bevált módszert is alkalmazok a szakirodalom olvasásakor: egyrészt a szakirodalomlánc módszerét, azaz elindulok egy összefoglaló mü bibliográfiája alapján és az ott hivatkozott müvek bibliográfiája alapján haladok tovább a kutatással. Másrészt a szerzőkövetés módszerét is, amely lehetővé teszi, hogy az alapszerzők egy-egy müvének elolvasása után megismerkedjek a szerzők egész munkásságával. Ez különösen a témában kikerülhetetlen nevek müveinek ismerete szempontjából fontos.

Számos - elsősorban külföldi - tanulmány foglalkozik a megelőzés, a mediáció lehetséges módozataival. Kevesen kapcsolják össze a népirtások kiváltó okait és a megelőzést. A legtöbb kutató igyekszik kerülni az általánosítást, és hangsúlyozza, hogy minden eset egyedi. Ennek egyik oka az is lehet, hogy a népirtások ugyan egyidősek az emberiséggel, a népirtáskutatás azonban viszonylag újkeletü tudomány. Én éppen az ellenkezőjét próbálom majd bizonyítani: olyan közös pontokra fókuszálok a különböző népirtások sikertelen megelőzése kapcsán, amelyek azonosításával a jövő népirtásai elkerülhetőek lennének. 


\section{2. fejezet: A genocídium fogalmának értelmezése}

A genocídium megelőzéséhez először is szükséges a genocídium fogalmának pontos meghatározása. Az elsődleges jogforrás az ENSZ Genocídium-egyezménye, azonban a szakirodalom élénk és vég nélküli vitát folytat arról, hogy az Egyezményben található definíció elfogadható-e, megfelelö-e.

A következő részben a genocídium fogalmának kialakulásával foglalkozom, valamint elemzem a legfontosabb jogforrás, az ENSZ Genocídium-egyezményének definícióját. Részletesen tárgyalom az Egyezmény felülbírálatára tett javaslatokat, valamint a jogi definíció problémás kérdéseit. Az összehasonlító genocídiumtörténet képviselői számos alternatív definíciót alkottak, azonban nem jutottak konszenzusra. Ezeket a definíciókat összevetve képet kaphatunk a jelenleg is folyó népirtáskutatás főbb szempontjairól, prioritásairól. Egy konkrét példa kiemelésével bizonyítom, hogy a fogalom használata a mai napig nem egyértelmü. Végül javaslatot teszek a Genocídiumegyezmény módosítására.

\subsection{A genocídium-fogalom eredete, nemzetközi jogi szabályozása}

A népirtás egyidős az emberiséggel, azonban CHURCHILL szavait idézve, a második világháború végéig a népirtás egy „név nélküli bün”38 volt. Többek között a második világháború tömeges atrocitásai hatására a nemzetközi jogászok is nagyobb számban kezdtek foglalkozni a kérdéskörrel. Azonban az elkövetési magatartások és a speciális szándék tényállásba ültetésére csak 1946-ban került sor, a népirtás nem szerepelt önálló bűncselekményként sem a Nürnbergi, sem a Tokiói Törvényszék Statútumában. ${ }^{39}$

RAPHAEL LEMKIN lengyel jogász 1944-ben vezette be a tudományos és jogi gondolkodásba a genocídium fogalmát. A kifejezés a görög ,genos” (törzs, család) és a latin „cide” (ölni) szavakból származik. ${ }^{40}$ Többek között a második világháború eseményei és LEMKIN intenzív lobbitevékenysége miatt a fogalom használata gyorsan

\footnotetext{
${ }^{38}$ Churchill rádióbeszéde 1941. augusztus 24-én

Forrás: http://www.preventgenocide.org/genocide/crimewithoutaname.htm, [2013.01.31.]

${ }^{39}$ Dr. Kirs Eszter [2003]: A népirtás büntettének nemzetközi jogi szabályozása. Miskolci Egyetem, ÁJK, Deák Ferenc Doktori Iskola, Doktoranduszok Fóruma, 2003. november 6. Novotni Alapítvány, Miskolc, 2003, 149.old.

${ }^{40}$ Lemkin, Raphael [1944]: Axis Rule in Occupied Europe: Laws of Occupation - Analysis of Government - Proposals for Redress, 79.old. Washington, D.C.: Carnegie Endowment for International Peace
} 
elterjedt: az ENSZ Közgyülésének 1946.évi 96(I) határozata már a genocídium, azaz népirtás büntettéről szól ${ }^{41}$.

A határozat szövege alapján a „[...]genocídium egész embercsoportok létjogosultságának tagadása, mint ahogyan az emberölés az egyén élethez való jogának tagadása. Ez a tagadás sokkolja az emberi faj lelkiismeretét, hatalmas veszteségeket jelent az emberiség számára, mivel ezek a csoportok kulturális és egyéb téren is hozzájárulnak az emberiség értékeihez, éppen ezért a népirtás ellentétes az erkölcsi joggal és az Egyesült Nemzetek szellemével és céljaival. Számos ilyen bűntett történt, amikor faji, vallási, politikai vagy egyéb csoportokat részben vagy teljes egészben elpusztítottak."42

A határozat nem elégedett meg annyival, hogy nemzetközi jogi értelemben büntettnek nyilvánította a népirtást, hanem a megelőzés és megbüntetés érdekében megbízta az Egyesült Nemzetek Gazdasági és Szociális Tanácsát (ECOSOC) egy egyezménytervezet összeállításával. Ennek a folyamatnak a végeredménye az 1948. december 9-én elfogadott A Népirtás Büntettének Megelőzéséről és Megbüntetéséről Szóló Egyezmény (a továbbiakban: Genocídium-egyezmény vagy Egyezmény), amely 1951. január 12-én lépett hatályba, kilencven nappal a huszadik ratifikáció után. Az Egyezménynek jelenleg 141 részes állama van ${ }^{43}$. WILLIAM SCHABAS 2009-ben kiadott Genocide in International Law c. könyvében az Egyezmény sikerét mérsékeltnek nevezi más ENSZ emberi jogi egyezményekhez képest. ${ }^{44}$ Ennek oka valószínűleg az, hogy a Genocídium-egyezmény egy hosszas tárgyalássorozat eredményeként létrejött diplomáciai kompromisszum, amely nem konszenzuson alapult. Ahogy LEO KUPER fogalmazott: az Egyezmény jogi fegyver, amely politikai kompromisszum eredménye. ${ }^{45}$ Másrészt az országok delegáltjai óvakodtak attól, hogy túlzott, később a belügyekbe való beavatkozásra lehetôséget adó tételeket szavazzanak meg.

\footnotetext{
41 96(I) 11 December 1946, The crime of genocide. http://www.un.org/documents/ga/res/1/ares $1 . h$ htm [2011.08.17.]

${ }^{42}$ http://daccess-dds-ny.un.org/doc/RESOLUTION/GEN/NR0/033/47/IMG/NR003347.pdf?OpenElement Resolutions adopted by the General Assembly during its first session [2011.08.17.]

${ }^{43}$ UN Treaty Collection, Convention on the Prevention and Punishment of the Crime of Genocide, STATUS AS AT: 17-08-2011 07:12:59 EDT http://treaties.un.org/Pages/ ViewDetails.aspx?src=TREATY\&mtdsg_no=IV-1\&chapter=4\&lang=en [2011.08.17.]

${ }^{44}$ A Faji Megkülönböztetés Valamennyi Formájának Kiküszöböléséről szóló Nemzetközi Egyezménynek 174 részes állama, a Nők elleni diszkrimináció minden formájának megszüntetéséről szóló Nemzetközi Egyezménynek 187 részes állama, a Gyermekek Jogairól Szóló Egyezménynek 193 részes állama van. Forrás: UN Treaty Collection, [2011.08.17.]

${ }^{45}$ Idézi: Jonassohn, Kurt; Björnson, Karin Solveig [1998]: Genocide and Gross Human Rights Violations in Comparative Perspective: In Comparative Perspective, Transaction Publishers, 1998,133.old.
} 
A Genocídium-egyezmény végleges szövegének 2. cikke alapján népirtást követ el, „(a)ki valamely nemzeti, etnikai, faji vagy vallási csoport teljes vagy részleges kiirtása céljából

a) a csoport tagjait megöli,

b) a csoport tagjainak súlyos testi vagy lelki sérelmet okoz,

c) a csoportot olyan életfeltételek közé kényszeríti, amelyek azt vagy annak egyes tagjait pusztulással fenyegetik,

d) olyan intézkedést tesz, amelynek célja a csoporton belül a születések meggátolása,

e) a csoporthoz tartozó gyermekeket más csoportba elhurcolja."

A 3. cikk szerint büntetendő a népirtás, a népirtás elkövetésére irányuló szövetkezés, közvetlen és nyilvános felbujtás népirtás elkövetésére, népirtás elkövetésének kísérlete, illetve a népirtásban való bünrészesség.

Ez a definíció két pontban is eltér a két évvel korábbi határozat szövegétöl. Az Egyezményben meglehetősen szűk a védett csoportok köre. Míg a közgyülési határozat még faji, vallási, politikai vagy más csoportok védelméről szól, az Egyezmény már csak a nemzeti, etnikai, faji és vallási csoportokat védi. A másik fontos eltérés, hogy a határozat konkrétan utalt a védett csoportok hozzájárulására az emberi kultúrához, így implicit módon a „kulturális genocídium” fogalmát támasztotta alá. ${ }^{47} \mathrm{Ez}$ az utalás azonban már nem szerepel a két évvel későbbi Egyezményben.

Az Egyezmény aláírását megelőző viták egyik fontos kérdése volt, hogy a politikai csoportok bekerüljenek-e a védett csoportok közé. Ezt azonban számos ország ellenezte arra hivatkozva, hogy a politikai csoport nem határozható meg objektíven, átmeneti, instabil közösség. Egyes delegáltak azért nem egyeztek bele a javaslatba, mert az esetleg jogalapot adhatott volna az országok belügyeibe való beavatkozásra. A küldöttek egy része azonban ki akarta terjeszteni a védett csoportok fogalmát bármilyen csoportra, még a gazdasági csoport is felmerült lehetőségként. ${ }^{48}$ Végül azonban a leszükítő felsorolás került be a végleges változatba. Szintén kérdéses volt a

\footnotetext{
${ }^{46}$ Jones, Adam [2010]: Genocide: A Comprehensive Introduction. Second Edition, Routledge/Taylor and Francis Publishers. Chapter one: The origins of genocide,13. old.

47 Shany, Yuval[2009]: The Road to the Genocide Convention and beyond, In: The UN Genocide Convention- A commentary, Edited by: Paola Gaeta, Oxford University Press, 2009 8-9.old.

48 Staub, Ervin[1989]: The Roots of Evil: The Origins of Genocide and Other Group Violence. Cambridge, UK: Cambridge University Press, 8.old.
} 
megbeszélések során az államok felelősségének problémája ${ }^{49}$ : Nagy-Britannia delegáltja a kormányok felelősségét hangsúlyozta az egyének felelősségével szemben ${ }^{50}$, hiszen az államapparátus aktív közremüködése nélkül nehezen lehet végrehajtani egy népirtást. Végül azonban erre vonatkozóan csak utalást helyeztek el az Egyezmény szövegében (9. cikk). ${ }^{51}$

\subsection{Az Egyezmény felülvizsgálatára irányuló kísérletek}

Az egyik legfontosabb kritika, amellyel a Genocídium-egyezményt illették a megszületése óta, hogy a népirtás definíciója túlságosan restriktív, a védett csoportok köre szük. Többek között emiatt nem is tartozott a hatálya alá egyértelmüen számos tömeges emberi jogi jogsértés és mészárlás, amelyet 1948 után elkövettek.

Az 1970-es évekre már sok nemzetközi jogász és szakértő csak afféle történelmi relikviaként tekintett az Egyezményre, hiszen még a Biztonsági Tanács állandó tagjai közül sem ratifikálta mindenki. ${ }^{52}$ A népirtás tilalma nem volt hatékony, és a Genocídium-egyezményt nem alkalmazták a jogi gyakorlatban. Ezért az ENSZ Diszkrimináció Megelőzésével és a Kisebbségek Védelmével Foglalkozó Albizottsága úgy döntött, vizsgálóbizottságot alapít az Egyezmény időszerüségének, használhatóságának felülvizsgálatára. ${ }^{53}$

1971-ban kinevezték különleges megbízottnak a ruandai NicODÈME RUHASHYANKIKOt, ${ }^{54}$ aki kutatócsoportjával több éves munka eredményeképpen 1978ban nyújtotta be az Albizottságnak a "The Study on the Question of the Prevention and Punishment of the Crime of Genocide" (A Genocídium Megelőzéséről és Büntetéséről

\footnotetext{
49 A Nemzetközi Bíróság 1996. július 11-i pergátló kifogásokról hozott döntésében kifejti, hogy az egyezmény kilencedik cikkében említett állami felelősség népirtásért, illetve a Genocídium-egyezmény harmadik cikkében említett tettekért, nem zárja ki az állami felelősség bármilyen formáját. Az egyezmény negyedik cikke sem zárja ki az állam felelősségét, amely a genocídium ,,vezetők”, illetve „köztisztviselők” általi elkövetését fejtegeti. In: Jurisdiction ratione materiae (paras. 27-33), Application of the Convention on the Prevention and Punishment of the Crime of Genocide (Bosnia and Herzegovina v. Serbia and Montenegro). Az állam felelősségre vonását e döntés szerint tehát a Genocídiumegyezmény nem zárja ki!

${ }^{50}$ Gerald Fitzmaurice angol követ véleménye szerint az Egyezmény rossz szemszögből közelítette meg a problémát, hiszen államok és nem egyének felelősségre vonásával kellene foglalkoznia, Forrás: Shany, Yuval[2009], 10.old.

51 „A Szerződő Felek közötti, jelen szerződés értelmezéséről, alkalmazásáról vagy teljesítéséről szóló, beleértve az állam genocídium, vagy a 3. cikkben felsorolt bármely más cselekmény miatti felelösségét illető vitás kérdésekkel kapcsolatban az államok a Nemzetközi Bírósághoz fordulhatnak bármely vitában részes állam kérésére."

${ }_{53}^{52}$ Ma már a BT minden állandó tagja részese az egyezménynek

53 Inazumi, Mitsue[2005]: Universal jursidiction under international law: Expansion of national jurisdiction for Prosecuting Serious Crimes under International Law. Intersentia, 72.old.

${ }^{54}$ Fournet, Caroline[2007]: The Crime of Destruction and the Law of Genocide Their Impact on Collective Memory. Ashgate Publishing Ltd., USA, xi: Ruhashyankiko Report
} 
Szóló Tanulmány) c. közel 200 oldalas jelentést, ${ }^{55}$ amelyet az Albizottság 1979-ben el is fogadott. RUHASHYANKIKO az esetjog, a tudományos anyagok és a hivatalos dokumentumok áttanulmányozása mellett számos kormánynak is küldött kérdőíveket, a Genocídium-egyezmény helyi alkalmazásával, valamint az egyezménnyel kapcsolatos kérdésekkel. ${ }^{56} \mathrm{~A}$ jelentés rendkívül alapos és tudományos igényű, amelyet alátámaszt az évekig tartó előzetes kutatómunka. RUHASHYANKIKO javaslatai között szerepelt az egyetemes joghatóság beemelése az Egyezménybe, mely meggyőződése szerint növelte volna az Egyezmény végrehajtásának hatékonysági fokát. RUHASHYANKIKO felfogása alapján az egyetemes joghatóság nem kötelezte volna a részes államokat a genocídium miatti vádemelésre, ez opcionális lett volna. Javaslata szerint az egyetemes joghatóság az aut dedere aut judicare elv ${ }^{57}$ alapján épült volna be az Egyezménybe. ${ }^{58}$

A dokumentum egy helyütt kísérletet tesz néhány népirtás konkrét megnevezésére, a felsorolásból azonban kihagyja az örmények esetét. A jelentéssel kapcsolatban felmerült legfontosabb kifogás is ezzel a hiányossággal függ össze: az előzetes anyagokban RUHASHYANKIKO még népirtásként aposztrofálta a török kormány örményekkel szemben elkövetett atrocitásait, a végleges változatban már nem utalt az esetre. RUHASHYANKIKO ezt a következőképpen magyarázta: „Úgy döntöttünk, hogy a nácizmus zsidó áldozatainak esetét megemlítjük, mert ezt mindenki ismeri és nem merült fel ezzel kapcsolatban kifogás, de más eseteket kihagytunk, mivel képtelenség lett volna egy teljes listát összeállítani, és mert fontos volt, hogy a nemzetközi közösségen belül megtartsuk a népirtással szembeni egységes hozzáállást, valamint számos esetben a múltba nézés már gyógyulófélben lévő régi sebeket tépett volna fel újra." 59

A jelentésről folyó megbeszélés az örmény-kérdés miatt politikai vitába torkollott. A Genocídium-egyezménnyel kapcsolatos módosító javaslatok megvitatását teljesen elkendőzte a politikai vita, így azokat nem is tárgyalták meg érdemben. Végül az

\footnotetext{
55 Ruhashyankiko, Nicodème [1978] Study on the Question of the Prevention and Punishment of the Crime of Genocide, United Nations, Economic and Social Council, Commission on Human Rights, SubCommission on Prevention of Discrimination and Protection of Minorities, E/CN. 4/Sub. 2/ 416, 4 July 1978

${ }^{56}$ Schabas, William [2000]: Genocide in international law- The crime of crimes The Press Syndicate of the University of Cambridge, United Kingdom, 465.old.

${ }^{57} \mathrm{Az}$ államok vagylagos kötelezettsége: vagy eljárnak az elkövetővel szemben, vagy más államnak kiadják ebböl a célból

${ }^{58}$ Inazumi [2005],72-73. old.

${ }^{59}$ UN Doc. E/CN.4/Sub.2/SR.822, 46. bekezdés
} 
Albizottság kis módosításokkal elfogadta a dokumentumot, és megállapította, hogy hozzáférhetővé kell tenni a lehető legszélesebb közönség számára. ${ }^{60}$

Ezután a meglehetősen felemás jelentés után az ENSZ-Albizottság sokáig nem foglalkozott a kérdéssel, és csak az 1980-as években került újra az érdeklődés homlokterébe. 1983-ban felkérték BENJAMIN WHITAKERt különleges megbízottnak, feladata a Ruhashyankiko-jelentés megújítása és korszerüsítése volt az azóta bekövetkezett fejlemények fényében. WHITAKER 1985-ben fejezte be jelentését ${ }^{61}$ "Revised and Updated Report on the Question of the Prevention and Punishment of the Crime of Genocide" (Átdolgozott és Korszerüsített Jelentés a Népirtás Megelőzéséről és Büntetéséröl) címmel.

Számos újító javaslatot tett, többek között a védett csoportok körét kibővítette volna a politikai és szexuális hovatartozás alapján elkülönülő csoportokkal, továbbá a „,szándékos mulasztást” (advertent omission) ${ }^{62}$ is büntettnek minősítette volna, valamint javasolta, hogy kerüljön ki az Egyezményből az a rész, mely szerint nem büntethető, aki felsőbb utasításra cselekszik. Megfontolásra ajánlotta továbbá a jelentés az ökocídium, az etnocídium, valamint a kulturális genocídium fogalmakat. WHITAKER - elődjével ellentétben - határozott felsorolásra tett kísérletet a jelentés 24 . bekezdésében: „A náci eltévelyedés sajnos nem az egyetlen népirtás a huszadik században. Több más példával együtt kimeríti ezt a fogalmat a hererók ellen 1904-ben elkövetett német mészárlás, az örmények ellen 1915-16-ban elkövetett török mészárlás, az 1919-es ukrajnai zsidóellenes pogrom, a hutuk ellen a tutszik által elkövetett mészárlások 1965-ben és 1972-ben, az Ache indiánok lemészárlása Paraguayban 1974 előtt, a vörös khmer mészárlás 1974 és 1978 között, valamint a jelenleg zajló bahá'í népcsoport mészárlása Iránban."63

A jelentést megvitató bizottsági ülésen megállapították, hogy a korábbi esetekkel való példálózás szükséges „a világ lelkiismeretének ébren tartásához”, és a további népirtások megakadályozásához. A vita más résztvevőinek véleménye szerint azonban WHITAKERnek arra kellett volna koncentrálnia, hogy a jövő népirtásait megakadályozza, a múlt nehezen bizonyítható vagy nyomozható adatainak megidézése nélkül. Ami az

\footnotetext{
${ }^{60}$ Schabas William [2000], 466.old.

${ }^{61}$ Whitaker, Benjamin [1985]: Revised and Updated Report on the Question of the Prevention and Punishment of the Crime of Genocide, United Nations, Economic and Social Council, Commission on Human Rights, Sub-Commission on Prevention of Discrimination and Protection of Minorities, E/CN.4/Sub. 2/1985/6, 2 July 1985.

${ }_{62}$ Amikor egy állam nem tesz semmit a népirtás elkerüléséért (pl. nem biztosít élelmet a tömeges éhhalál megelőzése érdekében)

${ }^{63}$ Whitaker Report
} 
örmény kérdést illeti, egyes felszólalók valóban elismerték, hogy az örmények ellen népirtást követtek el, mások azonban úgy vélték, hogy a mészárlás nem kellően dokumentált és koholt vádak képezik az alapját. ${ }^{64}$ Végül a bizottság megállapította, hogy a jelentés tartalmát és javaslatait illetően különböző vélemények hangzottak el. A javaslatok gyakorlatba átültetésére azonban ezúttal sem került sor.

\subsection{Az Egyezmény alkalmazása a gyakorlatban}

Az Egyezményt a mai napig nem módosították. Alkalmazására évtizedeket kellett várni, nemzetközi jogi értelemben idő előtt született. Radikális jogi újítás volt, amelyet a világ a háború utáni felfokozott hangulatban fogadott el. A tömeges nemzetközi jogi jogsértések kapcsán 1948 után évtizedekig a Genocídium-egyezmény volt az a jogi eszköz, amelyre hivatkoztak (általában olyan esetekben is, ahol nem teljesült a szigorú definíció valamely eleme), azonban a gyakorlatban nem használták. Az 1990-es években, a hidegháborús időszak végeztével azonban az emberi jogok védelme, és részeként az Egyezmény új életre kelt.

A Genocídium-egyezmény feltámadása a kilencvenes években annak is köszönhető, hogy gyökeresen megváltozott a jogi környezet. Míg az Egyezmény aláírásakor az állami szuverenitás szent és sérthetetlen volt, addig napjainkra - többek között az emberi jogok védelmének fokozatos fellendülése miatt - egyre több olyan jogi norma lép életbe, amely az egyént védi az állam által elkövetett bünökkel szemben. Sok nemzetközi szinten kötött egyezmény kötelességeket keletkeztet az állam oldalán, míg jogokat biztosít az egyénnek, így pedig áttöri az állami szuverenitás kemény falát. Korábban az volt az irányadó álláspont, hogy ami az állam határain belül történik, az csak az adott államra tartozik (domaine réservé).

A nemzetközi emberi jogi normák fejlödését sokáig, sőt a mai napig akadályozza az a tény, hogy a felelősök általában magas beosztásban voltak vagy vannak az elkövetés helyszínén, így az államok nehezen támogatnak olyan javaslatokat, amelyek eredményeképpen esetleg saját vezetőik kerülnének nemzetközi vagy más országok bíróságai elé. Valószínüleg ez is közrejátszott abban, hogy a Genocídium-egyezmény

\footnotetext{
${ }^{64}$ Schabas, William [2000]:. Genocide in international law: the crimes of crimes, Cambridge University Press, 466.old, idézet UN Doc, E/CN.4/Sub.2/1985/SR.57, 42.bekezdésből.
} 
tárgyalása során a delegáltak nagy része a lehető legszükebb és legszigorúbb genocídium-értelmezés mellett érvelt. ${ }^{65}$

Az Egyezmény első ,jogi felhasználására” 1993 márciusáig kellett várni, amikor a Nemzetközi Bíróság (International Court of Justice) a Genocídium-egyezményen alapuló két ideiglenes intézkedést hozott a jugoszláviai események kapcsán. ${ }^{66}$ Egy hónappal később a Biztonsági Tanács létrehozta a volt Jugoszlávia területén elkövetett bünöket kivizsgáló ad hoc bíróságot, mint a genocídium (valamint háborús és emberiesség elleni) büntettének tárgya szerinti hatáskörrel rendelkező és illetékes törvényszéket. ${ }^{67}$ 1994-ben, a ruandai népirtás után a Biztonsági Tanács egy második ad hoc bíróságot is alapított az Egyezményre hivatkozva Tanzániában. ${ }^{68} \mathrm{Az}$ azóta eltelt években már rendszeresen hivatkoznak jogi ügyekben az egyezmény definíciójára, és a kapcsolódó joganyag folyamatosan gyarapodott. Az első népirtás tárgyában született elmarasztaló ítéletre 1998-ban került sor, amikor JEAN-PAUL AKAYESUt a Ruandai Nemzetközi Törvényszék (ICTR) vonta felelősségre tetteiért. Több mint hatvan évvel a Genocídium-Egyezmény aláírása után tehát megállapítható, hogy a népirtás büncselekményének ma már nem csak elméleti megfogalmazása, hanem jelentős bírói gyakorlata is van.

\subsection{A genocídium fogalmának elemei az Egyezményben, és az ezzel kapcsolatos problematikus kérdések}

A Volt Jugoszláv Nemzetközi Törvényszék (ICTY) 1999-ben a JELISIC-ügy kapcsán a következő megállapítást tette: „A genocídium fogalmának két jogi eleme az Egyezmény 4. cikkelye alapján: (1) a jogsértés materiális eleme, amely a 4.cikkely 2. bekezdésében felsorolt cselekmények valamelyikének vagy mindegyikének a megvalósulása; (2) a jogsértés mens rea ${ }^{69}$-ja, amely a nemzeti, etnikai, faji vagy vallási csoport részének vagy

\footnotetext{
${ }^{65}$ Az Egyezmény ugyanis arra kötelezi a részes államokat, hogy tegyenek lépéseket a megelőzés és a felelösségre vonás érdekében.

${ }^{66}$ Application of the Convention on the Prevention and Punishment of the Crime of Genocode (Bosnia and HerzegovinaV. Yugoslavia (Serbia and Montenegro) 20 March, 1993 http://www.icjcij.org/docket/files/91/7199.pdf

Supplementary Submission in support of the Application of the Bosnia and Herzegovina instituting legal proceedings against Yugoslavia (Serbia and Montenegro) on the basis of the 1948 Genocide Convention and in the support of its Request for an Indication of Provisional Measures of Protection, 22 March, 1993. http://www.icj-cij.org/docket/files/91/13273.pdf

${ }^{67}$ UN Doc. S/RES/827[1993]

${ }^{68}$ UN Doc. S/RES/955[1994]

${ }^{69} \mathrm{Az}$ angolszász jogrendszerekben a büncselekménynek két fö fogalmi eleme van: a mens rea - bünös tudat, illetve az actus reus - bünös tett. Mindkét fogalmi elemnek meg kell valósulnia ahhoz, hogy a
} 
egészének kiirtására irányul."70 Tehát mind a mentális elem (a védett csoportok teljes vagy részleges kiirtására irányuló szándék) és a materiális elem (az Egyezmény 2. cikkének a), b), c), d), e) pontjában felsorolt cselekmények valamelyike) szükséges ahhoz, hogy egy büntettet népirtásnak lehessen nevezni.

A népirtást a védett csoportok tagjainak sérelmére követhetik el, így központi elem a védett csoportok köre. Az Egyezményt már megszületése óta kritikával illették (mint fentebb említettem, a WHITAKER-jelentés is tett javaslatot az ezzel kapcsolatos módosításra), amiért a védett csoportok közül számos potenciális célcsoport kimaradt (ideológiai, politikai, gazdasági, stb.). Másrészt az is gondot okozhat, hogy nincsenek nemzetközileg elfogadott definíciók a nemzeti, etnikai, faji vagy vallási csoportok meghatározására. A csoport kritériuma az eddigi joggyakorlat alapján, ${ }^{71}$ hogy viszonylagos állandósággal bír. A tagok általában beleszületnek a csoportba, és halálukig tagjai maradnak, a tagság az esetek túlnyomó részében nem a tag választásán alapul. Ha az áldozat nem tartozik a csoporthoz, de az elkövető feltételezett tagsága alapján követi el sérelmére a büncselekményt, a népirtás akkor is tényállásszerü. ${ }^{72}$

A nemzeti csoporton a törvényszékek gyakorlatában általában olyan csoportot értenek, amelynek tagjait közös állampolgárságon alapuló jogi kapcsolat tart össze. Az etnikai csoport tagjai közös nyelvvel vagy kultúrával bírnak. ${ }^{73}$ A faji csoport mára kissé idejétmúlt kategória, mivel a tudomány mai állása szerint az emberiségen belül nincsenek külön fajok. Az ICTR értelmezése alapján ${ }^{74}$ a faj egy adott földrajzi területen élő személyek csoportja, akik öröklött fizikai jellemvonások alapján azonosíthatók, függetlenül a nyelvi, kulturális, nemzeti vagy vallási tényezőktől. Szintén az ICTR meghatározása szerint ugyanazon valláshoz vagy felekezethez tartozó emberek csoportját tekinthetjük vallási csoportnak. $^{75}$

Értelmezési szempontból szintén kérdéses lehet a „teljes vagy részleges kiirtása céljából” kitétel, amely számos vita tárgya volt az Egyezmény megszületése óta. A

büncselekmény megvalósuljon. Ha hiányzik a bünös tudat, a tett - akár erőszakos cselekmény - nem feltétlenül lesz büntetendő (például: jogos védelem, beszámíthatatlanság).

${ }^{70}$ Jelisic ( IT-95-10-T), 62.

${ }^{71}$ Ez a csoport objektivista felfogása.

72 Sántha Ferenc [2007]: A népirtás büncselekményének néhány problematikus kérdéséről. Bünügyi Tudományi Közlemények 8: Tanulmányok Dr. Dr. H.C. Horváth Tibor Professor Emeritus 80. születésnapja tiszteletére, Miskolc, 165-166.old.

73 A Kayishema-ügyben eljáró tanács megállapította, hogy bár a hutuk és tutszik közös nyelvvel és kultúrával rendelkeznek, külön etnikai csoportoknak tekintendök, mert magukat is annak tartjákKayishema (ICTR-95-1, Trial Chamber), 98.- idézi Sántha[2007], 164. old.

${ }_{74}$ Akayesu (ICTR-96-4), 513.

${ }^{75}$ Ibid, 514. 
2001-es KRSTIC-ügyben a Volt Jugoszláv Nemzetközi Törvényszék úgy döntött, hogy a körülbelül 8000 boszniai muszlim tömeges meggyilkolása Srebrenicában kimeríti a népirtás fogalmát. Bár a KRSTIC-ügyben csak egy város muzulmán férfijai alkották a célzott részcsoportot, az áldozatok nagy száma és jelentősége miatt bizonyos mértékig a szélesebb körü boszniai muzulmán közösséget reprezentálták. A „részleges” kitételre reflektálva az ICTY kijelentette: „A rész jelentős része kell, hogy legyen az egész csoportnak. A Genocídium-egyezmény célja teljes emberi csoportok szándékos megsemmisítésének megakadályozása, és a célzott rész elég jelentős kell legyen ahhoz, hogy a csoport egészére hatással legyen."76 Megállapították, hogy míg a célzott személyek száma „szükséges és fontos kiindulópont”, azt is figyelembe kell venni, hogy mekkora arányt képviselnek a teljes csoporton belül, valamint mennyire kiemelkedő, illetve fontos szerepük van a célzott közösségen belül.

A népirtást a többi nemzetközi bűntettől - különös tekintettel az emberiesség elleni büncselekményekre - a speciális szándék, a dolus specialis választja el, amely egy csoport részének vagy egészének megsemmisítésére vonatkozik. Ez egyben a genocídium definíciójának legtöbbet vitatott eleme is, mivel a speciális szándék fennállása nehezen bizonyítható. A törvényszékek gyakorlata alapján a szándékra a körülményekből lehet következtetni. Ezeket a körülményeket az AKAYESU-ügy kapcsán fogalmazták meg: ${ }^{77}$

a) a büncselekmények ismétlődő jellege az elkövető vagy más elkövetők részéről

b) a védett csoport elleni támadások módszeressége, szervezettsége, a sértettek nagy száma

c) ha egy adott csoport tagjait módszeresen támadják, míg más csoport tagjait nem

d) a védett csoport alapvető értékei ellen irányuló bűncselekmények (pl. müemlékek elleni támadások). ${ }^{78}$

Az Egyezmény 2. cikkében öt pontban felsorolt alapcselekmények bármelyikének vagy többnek elkövetésével népirtás valósul meg, ha a fentebb említett speciális szándékkal hajtják végre a büntettet. A csoport tagjainak megölése közvetlen emberölést vagy olyan cselekményeket jelent, amelyek az áldozat halálához vezetnek.

\footnotetext{
${ }^{76}$ Krstic ( IT-98-33-A), 8.

${ }_{77}$ Akayesu (ICTR-96-4), 523.

${ }^{78}$ Ibid, 523.
} 
Bár a definícióban többes szám szerepel, a Törvényszékek gyakorlata alapján népirtást akár egy személy megölésével is megvalósíthat az elkövető, ha ez a cselekmény kiegészül más vádlottak hasonló jellegü cselekményeivel. ${ }^{79} \mathrm{~A}$ csoport tagjainak a csoporthoz tartozásuk miatt súlyos testi vagy lelki sérelem okozása alatt olyan széles körben végrehajtott kínzás, nemi erőszak, kényszerített droghasználat, csonkítás, embertelen vagy lealacsonyító bánásmód jellegü büntettek értendőek, amelyek súlyos traumát okoznak. Az Egyezmény nem határozza meg pontosan a súlyos testi vagy lelki sérelem fogalmát, az általánosan elfogadott álláspont csak azokat a súlyos sérelmeket sorolja ide, amelyek a csoport pusztulását okozzák. ${ }^{80}$ 1998-ban, az Akayesu-ügy kapcsán a Ruandai Nemzetközi Törvényszék megállapította, hogy a szexuális agresszió is lehet „népirtás ugyanúgy, mint bármely más cselekmény, amelyet azzal a speciális szándékkal követnek el, hogy egy bizonyos csoportot részben vagy egészben kiirtsanak". ${ }^{81}$ A szisztematikus nemi erőszak, megalázás és csonkítás, amely 1994-ben történt Ruandában „a tutszi nők, családjaik és közösségeik fizikai és pszichológiai megsemmisítését célozta". 82 A csoport olyan életfeltételek közé kényszerítése, amelyek az egész csoportot, vagy annak egyes tagjait pusztulással fenyegetik: részletesebben kifejtve jelenthetik a csoport túléléséhez szükséges erőforrásoktól való szándékos megfosztást (pl. tiszta víz, étel, ruha, orvosi ellátás). Ezt a vádlottak megvalósíthatják például a termények elkobzásával, az élelmiszerszállítmányok leállításával, kényszeráttelepítéssel (pl. sivatagba). Ez az alapcselekmény mulasztással is megvalósítható (a népirtás megelőzése érdekében szükséges intézkedések elmaradtak) ${ }^{83}$ A következő alapcselekmény olyan intézkedés megvalósítása, amelynek célja a csoporton belül a születések meggátolása. Ez magában foglalhatja a kényszersterilizácót, kényszerabortuszt, a házasság tilalmát, a férfiak és nők hosszú távú elválasztását, amelynek célja a csoporton belül a gyermeknemzés megakadályozása. Szintén népirtást követhet el, aki a csoporthoz tartozó gyermekeket más csoportba elhurcolja. Ezt az alapcselekményt kényszerrel valósítja meg az elkövető, amely lehet például fizikai erőszak, erőszakkal való fenyegetés, pszichológiai elnyomás. ${ }^{84} \mathrm{~A}$ fentiekből világosan kitünik, hogy nem szükséges feltétlenül embert ölni ahhoz, hogy valaki népirtást

\footnotetext{
${ }^{79}$ Sántha [2007], 167.old.

${ }^{80}$ Kirs [2003]: 150.oldal

${ }^{81}$ Akayesu (ICTR-96-4-T), 180.

82 Ibid, 181.

83 Elements of the Crime of Genocide. From the Report of the Preparatory Commission for the International Criminal Court, 6 July 2000, http://www.preventgenocide.org/genocide/elements.htm, [2011.09.10.]

${ }^{84}$ Ibid.
} 
kövessen el. Bármely másik, az Egyezményben nevesített, alapcselekmény, amelyet egy, a csoport létét fenyegető, szisztematikus akciósorozat keretében követnek el, kimerítheti a népirtás fogalmát.

Az Egyezmény 3. cikkében felsorolt „elkövetői alakzatokkal” (a népirtás elkövetésére irányuló szövetkezés, közvetlen és nyilvános felbujtás népirtás elkövetésére, népirtás elkövetésének kísérlete) kapcsolatban kiemelendő, hogy az elkövető akkor is felelősségre vonható, ha nem következik be a népirtás. ${ }^{85}$

\subsection{A genocídium fogalmának alternatív tudományos értelmezései}

A fentiekből érzékelhető, hogy a jogi megfogalmazás súlyos kérdéseket vet fel. A népirtás azonban nem csak a nemzetközi jog, hanem számos tudós és kutató vizsgálatának tárgya is. Ha tudományos szempontból tekintünk a genocídiumra, akkor a felelösök megbüntetésén kívül számos kérdés merülhet fel bennünk: hogyan alakult a népirtások története az emberiség történelme során, melyek a népirtások okai és következményei, hogyan lehetne megelőzni a népirtások előfordulását.

A jogi definícióról a fentiek fényében azt mondhatjuk, hogy materiális elemek tekintetében túlságosan is széles körü, számos viselkedésforma tartozik a hatálya alá, hogy csak néhányat említsünk: az emberöléstől a lelki sérelem okozásán keresztül a gyermekek csoportból való kiemeléséig. A jogi definíció azonban más szempontból, például a védett csoportok körével kapcsolatban, meglehetősen szűk körü. ${ }^{86}$

KuRT JONASSOHN és KARIN SOlveig BJÖRnson Genocide and Gross Human Rights Violations in Comparative Perspective címü könyvükben amellett érvelnek, hogy a Genocídium-egyezmény politikai tárgyalássorozat eredményeként született, definíciója nem szolgálhat a genocídiummal kapcsolatos tudományos kutatások alapjául.

A genocídiummal kapcsolatos tudásunk elmélyítéséhez azonban feltétlenül szükséges a fogalom világos körülhatárolása. Szintén alapkövetelmény, hogy a definíció a valóságot írja le, és alkalmas legyen az objektív használatra, amelyet sem a megfigyelő, sem mások előítéletei nem torzítanak. Annál is inkább, mivel kevés olyan

\footnotetext{
${ }^{85}$ Sántha [2007], 163. oldal

86 Rummel, R. J.[1997a]: Power kills: Democracy as a Method of Nonviolence. New Brunswick, N.J.,Transaction Publishers, http://www.hawaii.edu/powerkills/GENOCIDE.ENCY.HTM [2011.09.18.]
} 
területe van a társadalomtudományoknak, amelyet annyi prekoncepció és részrehajlás övez, mint a kormányok által a saját népük ellen elkövetett atrocitásokét.

Éppen ezért a genocídium definiálására a témával foglalkozó szakértők számos kísérletet tettek. JONASSOHN és BJÖRNSON azt is megállapította, hogy ezek az alternatív definíciók nem terjedtek el szélesebb körben. Ennek talán az az oka, hogy a szakértők hajlamosak egy adott korszak atrocitásait vizsgálva következtetéseket levonni. CHALK és JONASSOHN ${ }^{87}$ [1998] például egy 1990-es könyvében az egész emberi történelmet vizsgálva igyekeznek definíciót megfogalmazni, azonban LEO KUPER ${ }^{88}$ [1985] és R. J. RUMMEL $^{89}$ [1997b] gyakorlatilag csak a huszadik századot elemzi népirtások szempontjából, és a következtetéseiket, valamint a népirtás definícióját is ez alapján fogalmazzák meg. HELEN FEIN ${ }^{90}$ [1993] és BARBARA HARFF ${ }^{91}$ [2003] csak a második világháború utáni esetekkel foglalkoznak, és számtalanszor új kategóriák, mint a politicídium, valamint a democídium bevezetésével kísérleteznek, hogy a tárgyalt esetek körét kibővíthessék.

A második világháború vége óta megfogalmazott definíciókról általánosságban elmondható, hogy két fó csoportra oszthatóak. Vannak a keményvonalas és a mérsékeltebb álláspontot képviselők. Az előbbiek, attól tartva, hogy a népirtás kevésbé súlyos jogi kategóriává válik, ragaszkodnak egy szúkebb körü, szigorú megfogalmazáshoz; míg a mérsékeltek egy általánosabb érvényü definíciót preferálnak, így nem maradnának ki olyan atrocitások, amelyek erkölcsileg és logikailag is a genocídiumok közé tartoznának.

A következő részben a teljesség igénye nélkül ezeket az alternatív definíciókat tárgyalom részletesebben. ${ }^{92}$

PETER DROST ${ }^{93}$ 1959-ben a következőképpen definiálta a népirtást: Genocídium az egyének szándékos fizikai megsemmisítése valamely emberi közösségben való tagságuk alapján.

\footnotetext{
${ }^{87}$ Jonassohn, Kurt; Björnson, Karin, Solveig [1998]: Genocide and Gross Human Rights Violations in Comparative Perspective: In Comparative Perspective, Transaction Publishers, 133.old.

${ }^{88}$ Kuper, Leo [1985]: The Prevention of Genocide, New Haven, Yale University Press

${ }^{89}$ Rummel, R. J.[1997b]: Death by Government, Transaction Publishers

${ }^{90}$ Fein, Helen [1993]: Genocide: A Sociological Perspective, Newbury Park, California

${ }^{91}$ Harff, Barbara [2003]: No Lessons Learned from the Holocaust? Assessing Risks of Genocide and Political Mass Murder since 1955, American Political Science Review, February 2003

92 A következő források alapján: Jones, Adam [2010]: Genocide: A Comprehensive Introduction: Bounding Genocide: Comparative Genocide Studies, 16-20. oldal Second Edition, Routledge/Taylor and Francis Publishers, valamint: Aegis Trust: Other definitions of genocide http://www.aegistrust.org/Genocide/what-is-genocide.html, [2011.09.06.]
} 
1975-ben VAHAKN DADRIAN ${ }^{94}$ szerint a népirtás egy domináns csoport sikeres próbálkozása, formális felhatalmazással és az erőforrások egészéhez való hozzáféréssel, hogy egy kisebbségben lévő csoport létszámát csökkentse kényszerítés vagy halálos erőszak útján, végső cél a csoport kiirtása.

IRVING LOUIS HOROWITZ ${ }^{95}$ 1976-ban a népirtást ártatlan emberek az állam bürokratikus apparátusa által elkövetett módszeres és következetes megsemmisítésének tartotta. A népirtás szerinte rendszerezett erőfeszítést jelent egy nemzeti csoport, általában kisebbség likvidálására [...] és alapvető politikai erőfeszítés irányul arra, hogy a polgárok részt vegyenek benne, és egyetértsenek a népirtással.

LEO KUPER ${ }^{96}$ 1981-ben saját bevallása szerint is a Genocídium-egyezmény definícióját követte, de nem értett teljesen egyet vele. Súlyos hiányosságnak tartotta, hogy a politikai csoportok kimaradtak a védett csoportok köréböl. A faji nemzeti, etnikai vagy vallási csoportok ellen elkövetett népirtások szorosan kapcsolódnak a politikai konfliktusokhoz vagy éppen azok következményei. A politikai véleménykülönbségek KUPER szerint akár mészárlás illetve megsemmisítés alapját is képezhetik, éppúgy, mint a faji, nemzeti, etnikai vagy vallási különbségek. Azonban KUPER nem értett egyet azzal, hogy új definíciókat alkossunk a genocídium kapcsán, amikor rendelkezésünkre áll az ENSZ-egyezmény, amely a hatékony cselekvés alapja lehet, bármilyen szűk is legyen az a megfogalmazás.

YEHUDA BAUER ${ }^{97}$ 1984-ben különbséget tett a holokauszt és más népirtások között. A népirtás szerinte a tizenkilencedik század közepe óta a faji, nemzeti vagy etnikai csoportok eltervezett megsemmisítését jelenti, a következő módszerek által: (a) az elit vagy a társadalom egy részének szelektív meggyilkolása , (b) egy nemzeti (faji, etnikai) kultúra és vallásos életforma megsemmisítése „denacionalizációs” célzattal, (c) rabszolgasorba taszítás, ugyanezzel a szándékkal, (d) a nemzeti (etnikai, faji) gazdasági élet ellehetetlenítése ugyanezzel a szándékkal, (e) biológiai megtizedelés (gyerekek elrablása, a normális családi élet megakadályozása ugyanezen okból) [...] A holokausztot egy adott nemzeti, etnikai vagy faji csoport összes tagjának elöre megtervezett fizikai megsemmisítésének tartotta ideológiai vagy ál-vallási okokból.

\footnotetext{
${ }^{93}$ Drost, Pieter Nicolaas [1959]: Genocide; United Nations legislation on international criminal law, A.W. Sythoff

${ }_{94}^{94}$ Dadrian, Vahakn N.[1975]: The Typology of Genocide, International Review of Sociology 5, 2

95 Horowitz, Irving Louis [1976]: Genocide: State power and mass murder. New Brunswick, NJ: Transaction Books.

${ }^{96}$ Kuper, Leo [1981]: Genocide: its political use in the twentieth century, Yale University Press

${ }^{97}$ Bauer, Yehuda [1984]: Jewish foreign policy during the Holocaust. New York
} 
John L. ThOMPSON és GaIL A. QueTs ${ }^{98}$ 1987-ben a népirtást olyan tervszerü akciónak tartották, amely kívül esik az egyezményekben említett legitim háborús cselekményeken, és amelyet bárkik követnek is el, bármilyen szándékkal, a céljuk egy emberi közösség megsemmisítése.

IsIDOR WALlimanN és Michael N. DOBKOWSKI ${ }^{99}$ szintén 1987-ben a genocídiumról a következőket írták: egy faji vagy etnikai csoport egészének vagy egy részének kormány vagy megbízottai által történő szándékos, tervszerü megsemmisítése. Ez a tömeges emberölésen kívül ölthet más formát is: lehet kényszerdeportálás, szisztematikus nemi erőszak, illetve gazdasági leigázás.

HENRY HUTTENBACH ${ }^{100}$ 1988-ban röviden és tömören fogalmazta meg a népirtás lényegét: genocídium lehet bármilyen cselekedet, amely egy csoport létét veszélyezteti.

FRANK CHALK és KURT JONASSOHN ${ }^{101}$ 1990-es definíciója szerint a népirtás egyoldalú tömeges emberölés, amikor az állam vagy más szerv próbál megsemmisíteni egy csoportot. A csoportot és a csoporthoz tartozás feltételeit az elkövetők határozzák meg.

HELEN FEIN ${ }^{102}$ 1993-ban a genocídiumot hosszantartó tervszerű akciónak nevezte, amellyel az elkövetőnek az a célja, hogy fizikailag közvetlenül vagy közvetve megsemmisítsen egy közösséget, a tagok közötti biológiai vagy társadalmi reprodukció megakadályozásával. Ezt az akciót az elkövető akkor is folytatja, ha a célcsoport megadja magát vagy egyáltalán nem jelent fenyegetést.

STEVEN KATZ ${ }^{103}$ 1994-ben a szándék megvalósulásáról írt a népirtással kapcsolatban. KATZ szerint a definíció szempontjából mindegy, hogy milyen eszközökkel történik, vagy hogy mennyire sikeres bármilyen, az elkövető által meghatározott nemzeti, etnikai , faji, vallási, politikai, társadalmi, nemi vagy gazdasági csoport teljes elpusztítása.

\footnotetext{
${ }^{98}$ Thompson, John L. and Gail A. Quets [1987]: Genocide and Social Conflict: A Partial Theory and Comparison,' in Louis Kriesberg (ed.), Research in Social Movements, Conflicts and Change. Vol. 12. Greenwood, CN, JAI Press

${ }^{99}$ Wallimann, Isidor and Dobkowski, Michael N.[1987]: Genocide and the Modern Age: Etiology and Case Studies of Mass Death, Greenwood Press, Westport

${ }^{100}$ Huttenbach, Henry R.[1988]: Locating the Holocaust on the Genocide Spectrum: Towards a Methodology of Definition and Categorization, Holocaust and Genocide Studies 3:3

${ }^{101}$ Chalk, Frank and Jonassohn, Kurt [1990]: The history and sociology of genocide: analyses and case studies, Yale University Press

${ }^{102}$ Fein, Helen 1993]: Genocide: a sociological perspective, Sage Publications

${ }^{103}$ Katz, Steven T.[1994]: The Holocaust in Historical Context: The holocaust and mass death before the modern age, Oxford University Press
} 
ISRAEL CHARNY ${ }^{104}$ ugyanebben az évben általános értelemben a genocídiumot jelentős számú ember meggyilkolásának nevezte, amely nem katonai akcióban, hivatalos ellenfelek között zajlik, és az áldozatok védtelenek.

BARBARA HARFF ${ }^{105}$ 2003-ban összevonta a genocídium és politicídium fogalmát: a a kormányzó elitek vagy megbízottaik olyan hosszantartó politikájának elősegítését, végrehajtását vagy ezzel a politikával való hallgatólagos egyetértést jelentenek, amelynek célja egy közösségi, politikai vagy átpolitizált etnikai csoport részének vagy egészének megsemmisítése.

MANUS I. MiDLARSKY ${ }^{106}$ 2005-ben a genocídiumot ártatlan és védtelen férfiak, nők és gyerekek államilag finanszírozott szisztematikus tömeges meggyilkolásának nevezte, amelynek célja a csoport gyökeres kiirtása egy bizonyos területről.

Ugyanebben az évben MARK LEVENE ${ }^{107}$ szerint akkor beszélhetünk genocídiumról, ha egy állam úgy érzékeli, hogy egy társadalmi csoport, amelyet az állam összefüggő közösségként vagy közösségekként definiál, fenyegetést jelent az állam programjának megvalósítására, és az állam úgy próbálja orvosolni a helyzetet, hogy szisztematikusan a csoport egészének fizikai megsemmisítésére törekszik, vagy valamilyen módon arra, hogy többé ne jelentsen fenyegetést.

DANiEl Chirot és Clark MCCAUley ${ }^{108}$ 2006-ban újabb definíciót alkotott: népirtási szándékkal elkövetett tömeges emberölésen a politikailag motivált erőszakot értik, amely közvetlenül vagy közvetve egy célcsoport jelentős részét megsemmisíti, legyen szó katonákról vagy civilekről, tekintet nélkül korra és nemre.

JAMES M. SMITH [2006] ${ }^{109}$ szerint a genocídium nem háború vagy konfliktus, hanem a kirekesztés extrém formája. A kirekesztés végződhet azzal, hogy egy csoportot olyan mértékben kirekesztenek a társadalomból, hogy megsemmisítik.

JACQUES SÉMELIN ${ }^{110}$ 2007-es munkájában ugyanakkor a civil lakosság meggyilkolását tartotta genocídiumnak, amelynek célja egy, az elkövető által meghatározott kritériumokat teljesítő csoport teljes megsemmisítése.

\footnotetext{
${ }^{104}$ Charny, Israel W. [1994]: Toward a generic definition of genocide, University of Pennsylvania Press

${ }^{105}$ Harff, Barbara [2003]: No Lessons Learnt from the Holocaust? Assessing Risks of Genocide and Political Mass Murder since 1955, American Political Science Review, 97(1)

${ }^{106}$ Midlarsky, Manus I.[2005]: The killing trap: genocide in the twentieth century, Cambridge University Press

${ }^{107}$ Levene, Mark [2005]: Genocide in the Age of the Nation State: The rise of the West and the coming of genocide, I.B. Tauris and Co. Publishers, London

${ }^{108}$ Chirot, Daniel and McCauley, Clark [2006]: Why Not Kill Them All? The Logic and Prevention of Mass Murder, Princeton University Press

${ }_{109} \mathrm{http}: / /$ www.aegistrust.org/Genocide/what-is-genocide.html, James M. Smith speaking to the London Assembly, January 2006
} 
MARTIN SHAW ${ }^{111}$ 2007-ben erőszakos társadalmi konfliktusnak vagy háborúnak nevezte a népirtást, amely a civil lakosság egyes csoportjaira támadó fegyveres erőszakszervezetek és ezen csoportok vagy más, az erőszakot ellenző csoportok között zajlik.

DONALD BLOXHAM ${ }^{112}$ 2009-ban a következőképpen fogalmazta meg a genocídium lényegét: egy csoport jelentős részének meggyilkolása egy behatárolt vagy nem behatárolt területen, amelynek célja a csoport kollektív létének megszüntetése.

A definíciókról általánosságban elmondható, ${ }^{113}$ hogy a következő kategóriák közé csoportosulnak: elkövető, célcsoport, célok, stratégiák, szándékok illetve szinonimáik. Az elkövetők között számtalanszor előfordul az állami apparátus vagy megbízottainak megnevezése: HOROWITZ [1976] például egy állam bürokratikus apparátusát említi, PORTER [1982] kormányról vagy megbízottairól, HARFF [2003] a kormányzó elitekről vagy megbízottaikról beszél, LEVENE [2005] az államot nevezi meg. A szakértők nagy része kiemeli az állam szerepét a népirtásokban, de elismeri, hogy bizonyos esetekben más elkövetők is játszhatnak domináns szerepet. Az áldozatokat a meghatározások nagy része egy társadalmi kisebbségként nevezi meg. Szintén számos szerző fogalmazza meg valamilyen módon, hogy nem harcoló felek közül, hanem ,ártatlan emberek”, „ártatlan és védtelen férfiak, nők és gyerekek" közül kerülnek ki az áldozatok. Néhány definícióban tetten érhető, hogy a szerző hiányolja bizonyos csoportok beemelését a felelősségre vonás alapját képező jogi definícióba. A célok, a szándék körülhatárolása összességében kisebb szerephez jut, mint a Genocídium-egyezmény definíciójában. BLOXHAM [2009] szerint a népirtás célja a csoport kollektív létének megszüntetése, MiDLARSKY [2005] a csoport egy bizonyos területről való gyökeres kiirtását tartja fontosnak, KATZ [1994] a csoport teljes elpusztításáról beszél.

A meghatározások sokszínűsége is mutatja, hogy a szakértők között nem alakult ki egységes álláspont. Minden kutató a saját kutatási területének fontosabb elemeit igyekszik beemelni a definícióba, amely megfelelő alapul szolgál a tudományos munkához.

\footnotetext{
${ }^{110}$ Sémelin, Jacques [2007]: Purify and Destroy: The Political Uses of Massacre and Genocide, Columbia University Press, New York

${ }^{111}$ Shaw, Martin [2007]: What is genocide?, Polity Press

112 Bloxham, Donald [2009]: The final solution: a genocide, Oxford University Press

113 Jones, Adam [2010]: Genocide: A Comprehensive Introduction: Bounding Genocide: Comparative Genocide Studies, 20-22.oldal, Second Edition, Routledge/Taylor and Francis Publishers
} 
A következőkben egy konkrét példa, a darfúri események kapcsán bizonyítom, hogy a genocídium fogalom használata a mai napig nem tisztázott, sem politikai, sem tudományos körökben.

\subsection{Darfúr: népirtás vagy sem?}

A következökben a darfúri atrocitások történetének és kiváltó okainak rövid vázolásával ${ }^{114}$, azaz egy konkrét példán keresztül mutatom be, hogy milyen kétségek, illetve problémák merülnek fel a genocídium mint fogalom használatával kapcsolatban.

Szudánban az arab nomádok támadásai a főként fekete afrikai telepesek ellen az 1990-es évek elejétől kezdve egyre gyakoribbak és kegyetlenebbek lettek: több halálos áldozatot követeltek, és nagyobb anyagi kárt okoztak. A fokozódó erőszak egyrészt az elsivatagosodással, a vízhiánnyal magyarázható (egyre kevesebb volt a használható legelő), de befolyásolhatta az arab felsőbbségtudat erősödése és a kormány hozzáállása is. A döntő részben északiak vezette khartúmi kormány ugyanis módszeresen szemet hunyt a támadások fölött, évtizedekig másodrendü állampolgárokként kezelte a telepes fekete afrikaiakat. Az infrastrukturális fejlesztésekből egyes országrészek jellemzően kimaradtak: az útépítések, egészségügyi ellátás javítása, iskolák alapítása aránytalanul az ország központi részén koncentrálódott.

Az egyenlőtlen elbánás és jogfosztottság miatti felháborodás és a támadások egyre elviselhetetlenebb intenzitása lázadásra késztette a darfúri fekete afrikaiakat. A Szudáni Felszabadító Hadsereg, ${ }^{115}$ valamint az Igazság és Egyenlőség Mozgalom ${ }^{116}$ vezetésével 2003 tavaszán kezdték harcukat a kormányerőkkel szemben, és ezzel egy időben egyre többet hallhattunk Szudánról a médiában. Többek között a darfúri felkelök visszaszorítása indította a kormányerőket arra, hogy az addiginál erőteljesebben támogatni kezdje a dzsandzsavid milíciákat, amelyek szisztematikusan pusztították a fekete telepesek falvait. A kormány burkolt támogatásával a konfliktus etnikai élt is kapott: a fúr, maszalit és zaghawa népcsoportok falvait pusztították, míg az arabokat nem támadták.

A támadások során a reguláris khartúmi hadsereg először repülőgépekről bombázta a fekete afrikaiak falvait, majd ló- és teveháton érkeztek a dzsandzsavid milíciák, akik

\footnotetext{
${ }^{114}$ A történeti részhez felhasználtam Weitz, Eric D.[2003]: A Century of Genocide: Utopias of Race and Nation, Princeton University Press c. könyvének 17. fejezetét (555-600. oldal), melyben Samuel Totten a darfúri népirtás elözményeiről ír

${ }^{115}$ SLA: Sudan Liberation Army

${ }^{116}$ JEM: Justice and Equality Movement
} 
általában a romokat is felgyújtották az élelmiszertartalékokkal együtt. A fiúkat és férfiakat megölték, a nőket és lányokat elrabolták, megerőszakolták. A khartúmi kormány tagadta a milíciák támogatását, azonban szemtanúk és helyszíni megfigyelők ennek ellenkezőjét bizonyították. A dárfúri nem-arab közösségek elleni támadásoknak, emberöléseknek, erőszaknak, a segélyszállítmányok akadályozásának eredménye, hogy az ENSZ becslése szerint mintegy két és fél millió embernek kellett elmenekülnie Darfúrból, a halálos áldozatok számát kétszáz- és négyszázezer közé teszik.

Az Amerikai Egyesült Államok már 2004-ben népirtást emlegetett: 2004 szeptemberében COLIN POWELL akkori amerikai külügyminiszter népirtásnak nevezte a Darfúrban zajló eseményeket. ${ }^{117}$ A nemzetközi szervezetek és jogászok azonban sokkal óvatosabban bántak a kifejezéssel: az ENSZ 2005 elején megállapította, hogy emberiesség elleni büncselekményeket és nem népirtást követnek el Darfúrban. ${ }^{118} 2007$ októberében a Human Rights Watch "Questions and Answers: Crisis in Darfur" címü tanulmányában ${ }^{119}$ etnikai tisztogatásról és emberiesség elleni bűncselekményekről írt. Ezzel szemben Az Orvosok az Emberi Jogokért (Physicians for Human Rights) nevü jogvédő szervezet két helyszíni nyomozás során gyüjtött adatok alapján ${ }^{120}$ népirtásnak nevezte a kormányerők darfúri tevékenységét.

A tudományos élet szintén megosztott volt abban a tekintetben, hogy népirtásnak minősíthetőek-e a Darfúrban zajló események. MAHMOOD MAMDANI 2007-ben "The Politics of Naming Genocide: Genocide, Civil War, Insurgency címü cikkében ${ }^{121}$ arról ír, hogy inkább felkelésnek és az arra válaszul adott ellencsapásnak tartja a darfúri konfliktust. ALEX DE WAAL egy darfúri eseményekről rendezett vitában ${ }^{122}$ 2007-ben így fogalmazott: „Ha szó szerint alkalmaznánk az Egyezmény szövegét, akkor minden faji, vallási vagy etnikai csoport tagjainak sérelmére irányuló kísérletet, amelyet azzal a

${ }^{117}$ CNN World: Powell calls Sudan killings genocide. September 09, 2004. http://articles.cnn.com/200409-09/world/sudan.powell_1_larger-monitoring-force-darfur-arabjanjaweed?_s=PM:WORLD,[2011.09.23.]

118 Weitz, Eric D.[2003]: A Century of Genocide: Utopias of Race and Nation. Samuel Totten: The Darfur Genocide, chapter 17, 580.old.

119 Q \& A: Crisis in Darfur, April 25, 2008, http://www.hrw.org/news/2008/04/25/q-crisisdarfur,[2011.09.13.]

${ }^{120}$ Erről két tanulmány is készült: Heffernan, John, MPA; Leaning, Jennifer, MD, SMH[2006]: Darfur Assault on Survival, January 2006. http://www.physiciansforhumanrights.org/library/reports/darfurassault-on-survival-report-sudan-2006.html, Destroyed Livelihoods, A Case Study of Furawiya Village, Darfur. A Call for Security, Justice, and Restitution, February 2005. http://physiciansforhumanrights.org/library/reports/darfur-destroyed-livelihoods-2005.html, [2011.09.13.] 121 Mamdani, Mahmood [2007]: The Politics of Naming: Genocide, Civil War, Insurgency. London Review of Books, Vol. 29 No. 5., 8 March 2007, http://www.lrb.co.uk/v29/n05/mahmood-mamdani/thepolitics-of-naming-genocide-civil-war-insurgency, [2011.09.13.]

${ }_{22}$ Dueling Over Darfur, Nov 7, 2007, From Newsweek: http://www.thedailybeast.com /newsweek/2007/11/07/dueling-over-darfur.html, [2011.09.12.] 
szándékkal követnek el, hogy részben vagy egészben kiirtsák a csoportot, népirtásnak kellene tekinteni. Ez azt jelentené, hogy a szudáni polgárháború legalább tucatnyi epizódja népirtás lenne, csakúgy mint az Etiópiában az 1980-as években történtek, az ugandai események 1983-ban, szomáliai atrocitások 1988-ban és 1992-93-ban, valamint 2012-ben számos incidens a Kongói Demokratikus Köztársaságban, és még sok más eset. Beletartozna a legtöbb etnikai háború és ellencsapás [...]. A milíciák tagjainak rasszista sértései egyszerüen nem bizonyítják a népirtási szándékot."

SAMUEL TOTTEN azonban egyértelmüen népirtásként aposztrofálja a 2003 óta zajló darfúri eseményeket, GREGORY STANTON nemzetközi jogásszal együtt, aki célzott kérdésekkel és válaszokkal igyekszik bizonyítani igazát:

„Vajon „szándékos” a mészárlás?

Igen. A Nemzetközi Büntetőbíróság Statútumában nevesítik a büncselekmény elemeit, ennek alapján a genocídium közvetlen parancsok formájában vagy szisztematikus szervezésben megnyilvánuló politika eredménye kell, hogy legyen.

Igaz-e, hogy a darfúri öldöklést az AL-BASHIR-rezsim szervezte kormány által felfegyverzett dzsandzsavid milíciák, bombázók és nehézfegyverzetü helikopterek felhasználásával?

Igen.

Az áldozatokat etnikai és faji hovatartozásuk miatt választották?

Igen. A fúr, maszalit és zaghawa fekete afrikai falvakat lerombolták, míg a közeli arab falvakat érintetlenül hagyták. [...]

Ez a konklúzió elég ahhoz, hogy etnikai és faji csoportok szándékos részleges kiirtásáról beszéljünk?

Igen. Röviden, a darfúri erőszakhullám népirtás." 123

A Nemzetközi Büntetőbíróság OMAR AL-BASHIR ellen kiadott 2010. júliusi elfogatóparancsa ${ }^{124}$ már nevesítette a népirtás vádját. Az elfogatóparancs szerint 2003 áprilisa és 2008. július 14. között a kormány irányította különböző erők OMAR ALBASHIR, a hadsereg föparancsnoka és Szudán elnöke tudtával és irányításával népirtást hajtottak végre Darfúrban. Az elfogatóparancs külön kiemeli a speciális szándékot, és

\footnotetext{
${ }^{123}$ Stanton, Gregory H.: Proving Genocide in Darfur: The Atrocities Documentation Project and Resistance to its Findings, http://www.genocidewatch.org/provinggenocidedarfur.html,[2011.09.12.]

${ }^{124}$ Second Warrant of Arrest for Omar Hassan Ahmad Al Bashir, No. ICC-02/05-01/09. 12 July 2010, http://www.icc-cpi.int/iccdocs/doc/doc907140.pdf, [2011.09.13.]
} 
az Egyezményben nevesített öt népirtási alapcselekmény közül hárommal gyanúsítja a szudáni elnököt. ${ }^{125}$

A genocídium mint fogalom használata tehát napjainkban sem egyértelmü, bár az Egyezménnyel kapcsolatban egyre jelentősebb mennyiségü precedens és joganyag halmozódik fel. A politikusok azonban - a következményektől tartva - vonakodnak a kifejezés használatától. Ha valahol népirtás zajlik, óhatatlanul fel kell merülnie a katonai beavatkozás lehetőségének, ${ }^{126}$ amelyet a döntéshozók próbálnak elkerülni. Ezért gyakran csak utólag minősítenek népirtásnak olyan eseteket, amelyek minden tekintetben megfelelnek az Egyezmény követelményeinek.

Ahogy a fentiekből is kitünik, van néhány eset, amikor a népirtás átfedést mutat más, hasonló jellegü büncselekményekkel. Mielött levonnám a végkövetkeztetéseket a definíció alkalmazhatóságával és egyértelmüsítésével kapcsolatban, áttekintem a népirtás sajátos jellegzetességeit, amelyek elkülönítik többek között az etnikai tisztogatástól és az emberiesség elleni büncselekményektől.

\subsection{A népirtás elkülönítése más, hasonló jellegü büncselekményektől}

A népirtás fogalma a köztudatban gyakran összemosódik az etnikai tisztogatással, a háborús, illetve az emberiesség elleni büncselekményekkel. A következőkben a fogalmak világos elhatárolására teszek kísérletet.

Az etnikai tisztogatás fogalmát sokszor a népirtás szinonimájaként alkalmazzák helytelenül. Az etnikai tisztogatás kifejezést a második világháborúban használták elöször a nácik által támogatott horvátok, hogy a szerbek ellen elkövetett atrocitásaikat gyüjtőnévvel lássák el. A nácik is használták a „Säuberung” kifejezést az egyes területek zsidóktól való megtisztítására. ${ }^{127} \mathrm{Az}$ etnikai tisztogatás mint fogalom a kilencvenes években terjedt el igazán, az akkori Jugoszlávia területén a különböző felek által elkövetett célzott és szisztematikus akciók megnevezésére, amelynek során egész

125 „Ésszerü indokok alapján feltételezhetően Omar Al-Bashir speciális szándékkal (dolus specialis) cselekedett, hogy részben megsemmisítse a fúr, maszalit és zaghawa etnikai csoportokat...Ennek alapján Al-Bashirt büntetőjogi felelősség terheli mint közvetett tettest vagy közvetett tettestársat...a következő bünökért:

(i) népirtás emberöléssel,

(ii) népirtás súlyos testi vagy lelki sérelem okozásával,

(iii) népirtás olyan életfeltételek közé kényszerítéssel, amelyek pusztulással fenyegetnek"

126 Bár a Genocídium-egyezmény beavatkozásra nem, „csak” arra kötelezi az aláíró feleket, hogy lépéseket tegyenek a megelőzés és büntetés érdekében

${ }_{127}$ Totten, Samuel; Bartrop, Paul R. [2009, ed.]: Genocide Studies Reader, Chapter 3: Related terms, 57.o. 
csoportokat távolítottak el bizonyos területekről, hogy „megtisztítsák” azokat. A tisztogatás során számos módszert alkalmaztak (a teljesség igénye nélkül): civilek elleni támadások vagy támadással fenyegetés, kórházak elleni támadások, kínzás, nemi erőszak, emberölés, tömeges emberölés, ingó- és ingatlanvagyon eltulajdonítása, kulturális jelentőséggel bíró épületek megrongálása, lerombolása. A jugoszláviai háborúk során számos alkalommal elkövetett atrocitások során az etnikai tisztogatás fogalma lassan kikristályosodott: napjainkban egy csoport erőszakos eltávolítása egy bizonyos területről egy másik csoport által. Az elkövetők a „megtisztított” területet ezután birtokba veszik, mintha mindig is az övék lett volna. ${ }^{128}$

A megfigyelők szemében az etnikai tisztogatás gyakran egyet jelent a népirtással, azonban, ha a két fogalmat részletesebben megvizsgáljuk, határozott különbségekre figyelhetünk fel. A népirtásnak pontosan meghatározott definíciója van, amelyet tartalmaz az ENSZ 1948-as Genocídium-egyezménye, és ezt a definíciót a világ országainak többsége átvette. Az etnikai tisztogatásnak ezzel szemben nincs általánosan elfogadott definíciója, olyan büncselekményeket foglal magába, amelyek lehetnek háborús, emberiesség elleni bünök vagy akár népirtás. Mivel nincs pontosan definiálva, az etnikai tisztogatást külön nevesítve nem is tiltja olyan univerzális nemzetközi jogi egyezmény, mint a népirtás esetében a Genocídium-egyezmény. Számos nemzetközi egyezmény tiltja viszont az etnikai tisztogatás alá sorolható cselekményeket (például emberölés, deportálás, kínzás, nemi erőszak, a politikai, faji, vagy vallási alapon történő üldözés, népirtás...). ${ }^{129}$

Az etnikai tisztogatás és a népirtás közötti másik nagy különbség a szándék. Ha egy népcsoportot deportálnak vagy más erőszakos módszerrel kényszerítenek lakhelye elhagyására, az nem feltétlenül a népcsoport megsemmisítését szolgálja. Valószínüleg csak arról a bizonyos területről való eltávolítás a cél. Az ENSZ Genocídiumegyezményében viszont „kiirtása céljából” (intent to destroy) szerepel, nem pedig „eltávolítása céljából”. Egy csoport eltávolítása egy bizonyos terület megszerzése céljából, ha az eltávolított csoport máshol folytathatja életét, nem azonos a népirtással. Az etnikai tisztogatás, a kívánt terület „megtisztítása” során előfordulhat népirtás.

\footnotetext{
${ }^{128}$ Ibid, 58.o.

${ }^{129}$ Schabas, William [2003]: Ethnic Cleansing and Genocide: Similarities and Distinctions. European Yearbook of Minority Issues, Vol.3., 2003/4, Martinus Nijhoff Publishers
} 
Ilyenkor az a fő kérdés, hogy az elkövetőknek mi volt az elsődleges célja? Meg akarták szerezni a területet, vagy el akarták pusztítani a célcsoportot? ${ }^{130}$

A következő, meglehetősen nehezen definiálható fogalom, amelyet gyakran a népirtással „egy lapon” említenek, az emberiesség elleni bünök. WILLIAM SCHABAS "Crimes against humanity"131 c. cikkében összevont jogi fogalomnak nevezi az emberiesség elleni bűncselekményeket. Általában nem harcoló civilek ellen elkövetett jelentős emberi jogi jogsértéseket, atrocitásokat, tömeges emberölést értenek alatta. Ezen büncselekmények nemzetközi jogi tilalma viszonylag újkeletü, időben egybeesik az emberi jogi jogvédelem jelentős huszadik századi fejlődésével. Az emberiesség elleni büncselekményeket gyakran összemossák a háborús büncselekmények jogi kategóriájával, pedig a háborús bűnök a háborús szokások és jogi normák megszegését jelenti. SÁNTHA FERENC „Az emberiesség elleni büncselekmények” c. cikkében ${ }^{132}$ a következőképpen fogalmaz a két jogi fogalom közötti összefüggésről: „Amíg a háborús büncselekmények alapvetően a hadviselés törvényeinek és szokásainak a megsértését kimerítő magatartásokat jelentenek, addig az emberiesség elleni büncselekmények a humanitás, az alapvető emberi értékek eltiprását, az emberi méltóság kiemelkedően súlyos megsértését valósítják meg.”.

Az „emberiesség elleni bűncselekmények” kifejezés az I. világháború folyamán a szövetséges hatalmak által 1915-ben kiadott közös Nyilatkozatban tünt fel elöször, az örmény népirtás felelőseinek megbüntetésével kapcsolatban. (A felelősségre vonás végül elmaradt.) ${ }^{133}$ A II. világháború után a nürnbergi és a tokiói törvényszék alapokmányai alapján számos elmarasztaló ítélet született: a legtöbb vádlott vádpontjai között szerepelt az emberiesség elleni büncselekmények és közülük sokakat bűnösnek találtak. JULIUS STREICHER vádlottat például emberiesség elleni büntettekkel vádolták és elítélése után ki is végezték. ${ }^{134} \mathrm{~A}$ háborús bünösökkel szemben egyéb helyszíneken lefolytatott eljárásokban még használták ezt a vádpontot a negyvenes évek végéig, majd 1993-ig „eltűnt” a nemzetközi jogi porondról. Az 1993-ban, illetve 1994-ben jugoszláv háború során elkövetett nemzetközi büncselekmények, illetve a ruandai népirtás elkövetőinek felelősségre vonására létrehozott két ad hoc nemzetközi törvényszék

\footnotetext{
${ }^{130}$ Totten, Samuel; Bartrop, Paul R. [2009, ed.], 58.o.

${ }^{131}$ Schabas, William [2009]: Crimes against humanity, In: Genocide Studies Reader, edited by: Totten, Samuel; Bartrop, Paul R., 85.o.

132 Sántha Ferenc [2008]: Az emberiesség elleni büncselekmények. Miskolci Jogi Szemle, 3. évfolyam (2008) 1. szám, 52.o.

${ }^{133}$ Ibid, 51.o.

${ }^{134}$ http://www.britannica.com/EBchecked/topic/568753/Julius-Streicher [2013.02.09.]
} 
gyakorlata azonban ismét ítélkezik emberiesség elleni bủncselekményekkel kapcsolatos ügyekben, és a Nemzetközi Büntetőbíróság (ICC) joghatóságába tartozó büncselekmények között is szerepel. ${ }^{135}$

Az ICTY (Volt-Jugoszláv Nemzetközi Törvényszék) Statútumának 5.cikke, ${ }^{136}$ az ICTR (Ruandai Nemzetközi Törvényszék) Statútumának 3.cikke, ${ }^{137}$ valamint az ICC (Nemzetközi Büntetőbíróság) Statútumának 7.cikke ${ }^{138}$ a következőkben határozza meg az emberiesség elleni büncselekmények kategóriájába tartozó alapcselekményeket: emberölés, kiirtás, leigázás, kitoloncolás, bebörtönzés, kínzás, nemi erőszak, politikai, faji, vallási alapon való üldözés, személyek eröszakos eltüntetése, apartheid és egyéb embertelen cselekmények.

Sokáig kérdéses volt az emberiesség elleni bűncselekmények és a háború közötti összefüggés. Az első elmarasztaló ítéletek háború idején elkövetett büncselekményekre vonatkoztak, a szövetséges hatalmak közül föleg Amerika ragaszkodott ahhoz, hogy az emberiesség elleni büncselekmények csak fegyveres konfliktusok kapcsán fordulhatnak elő, ${ }^{139}$ és ez évtizedekig megmaradt a nemzetközi jogi közgondolkodásban, habár heves viták tárgyát képezte.

Meglehetősen egyértelmű jogi helyzetet teremtett végül az ICC statútuma 1998ban, amely nem említ semmilyen összefüggést a háború és az emberiesség elleni büncselekmények között, habár nem is említi explicit módon, hogy békeidőben és háborúban is elkövethetőek emberiesség elleni büntettek.

Visszakanyarodva az eredeti kérdéshez, a genocídium és az emberiesség elleni büncselekmények közötti különbséghez megállapíthatjuk, hogy miután az emberiesség elleni bünök békeidőben is elkövethetőek, néhány kisebb különbségtől eltekintve bármilyen népirtási alapcselekmény besorolható az emberiesség elleni büncselekmény kategóriájába. A népirtás az emberiesség elleni bűncselekmények legsúlyosabbikának tekinthető. Fontos különbség, hogy a Genocídium-egyezménynek nincs emberiesség elleni bűncselekményekre vonatkozó megfelelője.

„Hasznos” jogi kategória lehet az emberiesség elleni büntettek, ha nem lehet bizonyítani a speciális népirtási szándékot, valamint ha olyan csoport ellen elkövetett bűncselekményekről van szó, amelyeket nem nevesít a Genocídium-egyezmény

\footnotetext{
135 Sántha [2008]

${ }^{136} \mathrm{http}: / /$ www.icty.org/X/file/Legal\%20Library/Statute/statute_sept09_en.pdf, [2012.02.25.]

${ }^{137} \mathrm{http}: / / \mathrm{www} . u n .0 r g / i c t r / s t a t u t e . h t m l$, [2012.02.25.]

$138 \mathrm{http} / / /$ untreaty.un.org/cod/icc/statute/romefra.htm, [2012.02.25]

${ }^{139}$ Schabas [2009], 80.o.
} 
(például politikai, szociális, kulturális, stb.). Mivel az emberiesség elleni büncselekmények kapcsán nincs szigorúan meghatározott célcsoport (ezzel szemben genocídiumot jogilag csak faji, vallási, etnikai vagy nemzeti alapon lehet elkövetni), így általában amikor a népirtás vádjának nincs jogalapja, használható az emberiesség elleni büncselekmény vádpontja. Összességében tehát a népirtás - többek között szigorúbb jogi meghatározása miatt - súlyosabb büncselekménynek számít napjainkban, mint az emberiesség elleni büncselekmények ernyőfogalom.

\section{8. Összefoglalás}

Napjainkban is több millió embert fenyeget az a veszély, hogy népirtás vagy ahhoz kapcsolódó erőszakhullám során veszíti életét. A genocídium fogalma azonban komoly tudományos és politikai viharokat kavar. Az elsődleges jogforrás, a Genocídiumegyezmény szövege számos kérdést vet fel, ezekre az egyezmény alapján eljáró bíróságok joggyakorlata adhat választ.

A Genocídium-egyezményt 1948 után számos alkalommal bírálták. Tény, hogy materiális elemek tekintetében az Egyezményben szereplő definíció meglehetősen széles körü, hiszen számos viselkedésforma tartozik a hatálya alá. A védett csoportok körével kapcsolatban viszont viszonylag szűk körü a megfogalmazás. 1979-ben és 1985-ben is készültek az ENSZ megbízásából jelentések, amelyek az Egyezmény módosítására tettek javaslatokat, azonban a Genocídium-egyezmény a kritikák és esetleges hiányosságok ellenére a mai napig változatlan. Első „gyakorlati alkalmazására" 1993-ig kellett várni, ${ }^{140}$ az Egyezményen alapuló első elmarasztaló ítélet pedig 1998-ban született meg. ${ }^{141}$ Azóta - az emberi jogok egyre jelentősebb szerepe miatt - robbanásszerủen megnövekedett a kapcsolódó jogesetek száma.

A tudomány képviselői is igyekeztek megalkotni a saját szubjektív meghatározásukat a népirtásról, azonban különböző okok miatt egyik alternatív definíció sem terjedt el szélesebb körben.

\footnotetext{
${ }^{140}$ Application of the Convention on the Prevention and Punishment of the Crime of Genocode (Bosnia and HerzegovinaV. Yugoslavia (Serbia and Montenegro)) 20 March, 1993 http://www.icjcij.org/docket/files/91/7199.pdf

Supplementary Submission in support of the Application of the Bosnia and Herzegovina instituting legal proceedings against Yugoslavia (Serbia and Montenegro) on the basis of the 1948 Genocide Convention and in the support of its Request for an Indication of Provisional Measures of Protection, 22 March, 1993 http://www.icj-cij.org/docket/files/91/13273.pdf [2013.02.07.]

141 The Prosecutor v. Jean-Paul Akayesu (Trial Judgement), ICTR-96-4-T, International Criminal Tribunal for Rwanda (ICTR), 2 September 1998, http://www.unhcr.org/refworld/publisher, ICTR, 40278fbb4,0.html [2013.02.07.]
} 
A genocídium mint fogalom napjainkban tehát továbbra sem egyértelmü. A politikusok óvakodnak használatától, mivel felveti az intervenció kényes kérdését. A témával foglalkozó szakértők megosztottak, amikor egy aktuális eset kapcsán kell nyilatkozniuk. A jogászok a felelősségre vonásra helyezik a hangsúlyt, a precedensek egyre bővülö köre pedig segítséget nyújt az Egyezmény értelmezéséhez.

A fogalom világos, objektív körülhatárolása mind a tudományos, mind a hétköznapi életben feltétlenül szükséges lenne ahhoz, hogy egy ilyen prekoncepciókkal és elöítéletekkel terhes témával kapcsolatban elmélyítsük tudásunkat, és hozzájáruljunk a megelőzéshez. Ettől függetlenül érdemes elgondolkodni a Genocídium-egyezmény módosításáról. A következőkben erre teszek javaslatot.

\subsection{Javaslat a Genocídium-egyezmény módosítására}

Az alternatív definíciókat áttekintve megállapítható, hogy a legtöbb szakértő elégedetlen a jogi definícióval, és vagy a Genocídium-egyezményben foglalt meghatározás kiszélesítése mellett foglal állást, vagy a fogalom „súlyának” megőrzése érdekében kitart a jelenlegi értelmezés mellett.

Nyilvánvaló, hogy az Egyezményben a célcsoportok közül kimaradt néhány fontos csoport, legfeltünőbb ez a hiányosság a politikai, gazdasági és kulturális csoportok tekintetében. Az Egyezmény elfogadásának körülményeit ismerve az is egyértelmü, hogy a célcsoportok szük körének kijelölése nem véletlen, hanem bizonyos ENSZtagállamok határozott álláspontjának eredménye. Az a kérdés, hogy az elmúlt több mint hatvan évben megváltozott-e ezen országok percepciója, állami szuverenitásról alkotott képe. A Genocídium-egyezmény felülbírálatára tett sikertelen kísérletek ezt legalábbis kétségessé teszik. Ezt igazolja a védelem felelőssége elvének ${ }^{142}$ ellentmondásos megítélése: számos ország a mai napig félti állami szuverenitását, és nem hajlandó beleegyezni annak korlátozásába. Márpedig a definíció kiszélesítését sok ország az állami szuverenitás korlátozásának tartaná (mivel minél több a védett csoport, annál „könnyebb” beavatkozni egy állam belügyeibe a védett csoportok jogainak tömeges megsértése esetén).

Ugyanakkor a politikai csoportok védelme kulcsfontosságú. BARBARA HARFF, a „politicídium” fogalmának megalkotója szerint az elmúlt században a „népirtó rendszerek" szemében egyre inkább a politikai hovatartozás volt az emberek

\footnotetext{
${ }^{142}$ Ezt az elvet részletesebben tárgyalom a Népirtás-megelőzés aktuális fejleményei című fejezetben
} 
megítélésének mércéje. ${ }^{143}$ A kategória átmeneti jellegét tagadja LEO KUPER is, aki szerint ,a politikai hovatartozás lehet olyan állandó és megváltoztathatatlan, mint a származás” ${ }^{144}$, illetve gyakran „lehetetlen leválasztani a politikai összetevőt az etnikai, faji vagy vallási jellemzőkről". ${ }^{145}$. Jelen állás szerint jogi értelemben nem minősülne népirtásnak például SzTÁLIN „osztályellenségeinek”(mintegy húszmillió ember) kiirtása a Szovjetunióban, vagy POL POT rezsimjének kambodzsaiak ellen elkövetett tömegmészárlása (az áldozatok száma az eltérő becslések alapján egy- és hárommillió között mozog). Egyes szakértők azzal próbálják eloszlatni a helyzet abszurditását, hogy a meggyilkoltak között nemzeti, etnikai, vallási vagy faji alapú csoportokat keresnek, akiket vélhetőleg identitásuk miatt öltek meg. ${ }^{146}$

Ez azonban fordított gondolkodás: a definíciót kellene átalakítani annak érdekében, hogy lefedje többek között a két fent említett esetet is. Hiszen ha RAPHAEL LEMKIN szellemében gondolkodunk a népirtásról, akkor ezek az esetek igenis genocídiumnak minősülnek.

A fentiek értelmében két lehetséges megoldás van:

1. A Genocídium-egyezményt módosítani kell a következőképp (a javasolt módosítás dőlt betüvel szerepel): Népirtást követ el, „(a)ki az általa meghatározott kritériumokon alapuló csoport teljes vagy részleges kiirtása céljából

a) a csoport tagjait megöli,

b) a csoport tagjainak, a csoporthoz tartozása miatt súlyos testi vagy lelki sérelmet okoz,

c) a csoportot olyan életfeltételek közé kényszeríti, amelyek azt vagy annak egyes tagjait pusztulással fenyegetik,

d) olyan intézkedést tesz, amelynek célja a csoporton belül a születések meggátolása,

e) a csoporthoz tartozó gyermekeket más csoportba elhurcolja."

2. A Genocídium-egyezményhez hasonló egyezményt kell elfogadni, amely védi az egyezményből kimaradt csoportokat a megsemmisítéstől. Ezek a csoportok a

\footnotetext{
${ }^{143}$ Harff, Barbara [2009]: Recognizing Genocides and Politicides, In: Genocide Studies Reader, Bartrop, Paul R.; Totten (ed.):, Samuel, Routledge

${ }^{144}$ Kuper, Leo [1985]: The Prevention of Genocide, New Haven, Yale University Press, 16.old.

145 Ibid, 100.old.

${ }^{146}$ Ld. Például Letgers, Lyman [1984]: The Soviet Gulag: Is It Genocide?, In: Charny, Israel (ed.): Toward the Understanding and Prevention of Genocide: Proceedings of the International Conference on the Holocaust and Genocide, Boulder, Westview Press
} 
következök lehetnek: politikai, gazdasági, kulturális, szexuális hovatartozáson alapuló csoportok.

Van-e reális esélye ezeknek a javaslatoknak? Akkor sikerülhet a módosítás, ha a régi keretek között már nem tölti be funkcióját az Egyezmény. Azaz, ha a legtöbb népirtást a jövőben olyan csoportok sérelmére követik el, amelyek nem szerepelnek az Egyezményben, talán a legtöbb ország belátja a változtatás szükségességét. 


\section{3. fejezet: A népirtás megelőzésének nehézségei}

\subsection{A megelőzés gyakorlati nehézségei}

A népirtás megelőzésének hangoztatása terén a nemzetközi közösség eredményei messze túlmutatnak a gyakorlatban elért szerény sikereken. A hatékony gyakorlati megelőzés útjában számos akadály áll.

Az egyik legfontosabb akadály éppen a büncselekmény speciális jellegéből fakad: bár egyes esetekben egyértelmű a népirtás megjelölés (mint Ruanda vagy a holokauszt), a kifejezés használata, ahogy erre az első fejezetben utaltam is, meglehetősen ellentmondásos. Nem éles a határvonal a civil csoportok ellen elkövetett tömeges emberi jogi jogsértések és az Egyezmény definíciója szerinti népirtás között. Míg az erőszakos cselekmények szempontjából lényegtelen a megnevezés, a nemzetközi közösség, valamint közvélemény szempontjából különösen fontos. A népirtás egyértelmüen cselekvésért kiált.

Mivel aktív cselekvés helyett gyakran a megnevezésről folyik a vita, számos aktivista és szakértő igyekezett alternatív javaslatokkal elterelni a figyelmet a „túldefiniált” genocídium-fogalomról a hatékonyabb megelőzés érdekében.

Érdemes kiemelni többek között SCOTT STRAUS ${ }^{164}$ javaslatát, aki szerint a genocídiumot a központilag irányított, szervezett, civilek ellen irányuló erőszakos cselekmények közé kellene sorolni, vagy figyelmet érdemel az Intervenció és Állami Szuverenitás Nemzetközi Bizottságának ${ }^{165}$ „tömeges életvesztés” (large scale loss of life) ajánlása. WILLIAM SCHABAS ${ }^{166}$ nemzetközi jogi szakértő kimerítően foglalkozott a népirtás témakörével nemzetközi jogi szempontból, szerinte az „emberiesség elleni bűncselekmény” kifejezés hasznosabb lehet, ha a gyakorlati megelőzés a cél.

Ezek a kifejezések nem olyan „telítettek”, mint a genocídium, mivel ez utóbbi mintegy önmagában etikai felszólítás. A kevésbé erős fogalmak használata egyrészt elönyös lehet, mert a fent említett kifejezéseket rövidebb időn belül alkalmazhatják az erőszakos cselekmények leírására. Azonban egyúttal a cselekvési küszöb is alacsonyabb

\footnotetext{
${ }^{164}$ Straus, Scott [2007]: Second Generation Comparative Research on Genocide, World Politics 59, 476501.oldal

${ }^{165}$ International Commission on Intervention and State Sovereignty [2001]: The Responsibility to Protect. Ottawa, Canada, the International Development Research Centre

${ }^{166}$ Schabas, William [2006]: The UN International Criminal Tribunals: The Former Yugoslavia, Rwanda and Sierra Leone, Cambridge, Cambridge University Press
} 
lesz, mert a fenti javaslatok súlyos fogalmak, mégsem jelentenek olyan sürgető felszólítást a cselekvésre, mint a genocídium. ${ }^{167}$

A másik akadály, amely a gyakorlati cselekvés útjában áll, a megelőzés paradoxona. Ha a megelőzés sikeres volt, akkor már senki sem állíthatja biztosan, hogy az elkerült erőszakos cselekmény népirtás lett volna. Hiszen csak akkor minősíthetünk egy eseményt népirtásnak, ha már elkövetésre került. Éppen ezért a népirtásmegelőzésnek konfliktusok, illetve kezdődő konfliktusok széles körét számításba kell vennie, attól függetlenül, hogy utólag megállapítható-e a népirtási szándék. A hatékony megelőzésnek ezért rendszerszinten kell kezelnie a konfliktusokat, és számolnia kell az egyes csoportok jogfosztottságának, az éhínségek, menekülthullámok, stb. hosszú távú hatásaival. Így természetesen számos ponton a népirtás-megelőzés összeér, átfedést mutat az általános konfliktus-megelőzéssel.

Azonban a népirtás megelőzésére szemben más jellegü konfliktusokkal jogi kötelezettséget ír elő a Genocídium-egyezmény: a megelőzés elsősorban annak az országnak a felelőssége, ahol a bűntény történne. ${ }^{168}$ Tehát mindenekelőtt maga az érintett ország felel azért, hogy a hatalmában álló minden eszközzel megelőzze a népirtást.

2007-ben született először országot elmarasztaló ítélet ebben a kérdésben: a már említett Bosznia-Hercegovina által 1993-ban az akkori Jugoszláv Szövetségi Köztársaság ellen a Nemzetközi Bírósághoz benyújtott kereset az 1948. évi genocídium egyezmény alkalmazása tárgyában. ${ }^{169}$ A Bíróság hosszas eljárás után, 2007 februárjában hozott döntést az ügyben. ${ }^{170}$ Megállapította, hogy Szerbia az 1995-ben Srebrenicában zajlott események kapcsán megsértette a Genocídium-egyezményből fakadó népirtásmegelőzési kötelezettségét, ${ }^{171}$ valamint Ratko Mladič hágai törvényszék számára

\footnotetext{
167 Totten, Samuel; Parsons, William S.[2009]: Century of genocide: critical essays and eyewitness accounts, Routledge,chapter 18: Bridget Conley-Zilkic, Samuel Totten : The Challenges of Preventing and Responding to Genocide, 609-636.oldal

168 Office of the Special Adviser on the Prevention of Genocide /Preventing genocide: "The primary responsibility to prevent and stop genocide lies with the State in which this crime takes place." http://www.un.org/en/preventgenocide/adviser/genocide_prevention.shtml, [2012.01.25.]

${ }^{169}$ Lamm Vanda [2003]: A délszláv háború újabb felvonása a Nemzetközi Bíróság előtt. A NATO bombázások ügye a Bíróság előtt, http://www.balkancenter.hu/pdf/elemzes/lammv.pdf, [2012.01.25.]

${ }^{170}$ International Court of Justice: Case concerning application of the convention on the prevention and punishment of the crime of genocide, Judgment of 26 February, 2007. http://www.icjcij.org/docket/files/91/13685.pdf, [2012.01.25.]

${ }^{171}$ A Nemzetközi Bíróság fennállása óta először a genocídium tényét állapította meg: Srebrenicában népirtás történt.

„A hágai bírák többségi véleménnyel megállapították, hogy Szerbia:

$\square$-szerződéses kötelezettségével ellentétesen nem követett el népirtást,

$\square$-nem szövetkezett s nem bujtott fel népirtás elkövetésére,
} 
történő kiadásának elmulasztásával a népirtás megbüntetésének kötelezettségét is, illetve nem tett eleget a Bíróság 1993-as ideiglenes intézkedéseinek ${ }^{172}$, mivel nem foganatosított minden lehetséges lépést a Srebrenicában 1995-ben lezajlott népirtás megelőzése érdekében.

Kérdéses azonban, hogy amennyiben egy ország, mint a 2007-es ítéletben elmarasztalt Szerbia, nem tesz eleget népirtás-megelőzési kötelezettségének a saját területén, kire száll át a felelősség. Erre a kérdésre még nem született megnyugtató válasz, bár a Nemzetközi Bíróság döntése DiANE ORENTLICHER (a témával foglalkozó nemzetközi jogász) szerint akár burkolt felhívásként is értelmezhető arra nézve, hogy nem kell addig várni, míg egyértelművé válik a népirtás. Ha egy adott ország elmulasztja, akkor más országoknak kell közbelépni a megelőzés érdekében. ${ }^{173} \mathrm{~A}$ népirtások megelőzését sok esetben a szomszédos országok, illetve a nemzetközi közösség közönye is akadályozza.

Amikor Ukrajnában súlyos éhínség volt 1932-33-ban, ${ }^{174}$ egy magas rangú tisztviselőknek tartott szovjet megbeszélésen az egyik funkcionárius elkezdett az áldozatok hatalmas számáról beszélni, Sztálin azonban közbeszólt: „Ha egy ember hal

\footnotetext{
$\square$-valamint nem terheli bünrészesség sem népirtás elkövetésében,

$\square$-de az 1995-ben Srebrenicában zajlott eseményekkel kapcsolatosan megsértette a népirtás megelőzésére vonatkozó kötelezettségét,

$\square$-illetve a népirtás elkövetésével vádolt Ratko Mladić hágai törvényszék számára történő kiadásának elmulasztásával szintén vétett a genocídium egyezményből fakadó szerződéses kötelezettségével szemben,

$\square$-nem tett továbbá eleget a Bíróság által még 1993-ban elrendelt ideiglenes intézkedéseknek azzal, hogy nem foganatosított minden lehetséges lépést a Srebrenicában 1995-ben lezajlott népirtás megelőzése érdekében.

A Nemzetközi Bíróság szerint Szerbia haladéktalanul köteles hatékony intézkedéseket tenni a népirtás elkövetőinek megbüntetésére irányuló szerződéses kötele zettsége teljesítése érdekében. Köteles átadni a volt Jugoszláviában elkövetett háborús bűnösöket felelősségre vonó törvényszéknek minden népirtással vádolt személyt, illetve köteles teljes mértékben együttmüködni a hágai törvényszékkel.” (In: Csapó Zsuzsanna: Nemzetközi bíróságok fellépése a gyermekeket fegyveres konfliktusok idején védő nemzetközi normák megszegése esetén, http://www.mjsz.uni-miskolc.hu/200901/6_csapozsuzsanna.pdf, a bírósági ítélet összefoglalója alapján: Summary of the Judgment of 26 February 2007, Application of the Convention on the Prevention and Punishment of the Crime of Genocide (Bosnia and Herzegovina v. Serbia and Montenegro), http://www.icj-cij.org/docket/files/91/13687.pdf)

${ }^{172} \mathrm{http} / / /$ www.icj-cij.org/docket/files/91/7349.pdf [2013.01.07.] , valamint az értelmezésen segítséget nyújtott:Hoffmann Tamás [2006]: Egy elöre meghozott ítélet krónikája? A Népirtás büntettének megelőzéséről és megbüntetéséről szóló egyezmény alkalmazása (Bosznia és Hercegovina kontra Szerbia és Montenegró) ügy a hágai Nemzetközi Bíróság elött, Kül-Világ, III. évfolyam. 2006/2.

${ }^{173}$ Interview with Diane Orentlicher [2007]:Justice in the Courts, An episode from VOICES ON GENOCIDE PREVENTION, http://www.podfeed.net/episode/Diane+Orentlicher+Justice+in+the+ Courts/1105524 [2012.01.25.]

174 Óvatos becslések szerint is 6-7 millió halálos áldozatot követelt a Szovjetunióban az 1932-1933-as éhínség - a legtöbbet Ukrajnában és Dél-Oroszország ukránok lakta vidékein, In: Vida László[2003]: Az ítélet: Éhhalál, http://www.mult-kor.hu/cikk.php?id=5461[2012.02.29.], valamint Az 1932-1933-as Ukrajnai Éhínség. Az ukránok ellen elkövetett népirtás, In: Ukrajna Magyarországi Nagykövetsége, http://www.mfa.gov.ua/hungary/hun/publication/content/20720.htm
} 
éhen, az tragédia. Ha milliók halnak meg, az csak statisztika."175 Sztálin megfigyelésének helyességét napjainkban már pszichológiai kísérletek is alátámasztják: Paul Slovic és Deborah Small, a University of Pennsylvania és a George Loewenstein of Carnegie Mellon University kutatói megállapították, hogy egy hétéves afrikai éhező gyermek fotója láttán felajánlott adományok mértéke jelentősen csökkent, ha a gyermek fényképe mellett feltüntették, hogy rajta kívül hány millió gyermek szorulna rá a segítségre. ${ }^{176}$

Több más kísérlettel is sikerült igazolni, ${ }^{177}$ hogy a nagy számok akadályozzák az együttérzés kialakulását. Az „együttérzési fáradtságnak” (compassion fatigue) jelentős szerepe lehet abban, hogy a világ tehetetlenül végignézi, amint százezrek vagy milliók lelik halálukat egy népirtásban. SLOVIC szerint tehát nem érzéketlenségünk hátráltat bennünket a népirtások megakadályozásában, hanem megbénít bennünket, hogy képtelenek vagyunk felfogni a nagy számokat, és összekapcsolni azokat a tömeges emberi katasztrófákkal. ${ }^{178}$

A megelőzés sikere a fent említett tényezőkön kívül azon áll vagy bukik, hogy a népirtásra utaló jeleket, a tömeges erőszak útjára terelő tényezőket sikerül-e időben felismerni. A következő részben a népirtás előjeleit, a társadalomtudósok komparatív vizsgálatainak eredményeit vizsgálom meg.

\subsection{A genocídium kiváltó okai, előjelei, és szerepük a megelözésben}

Amikor a már bekövetkezett népirtásokat vizsgáljuk, óhatatlanul felmerül a kérdés, hogy sikerült-e az emberiségnek valamilyen tanulságot levonnia. Tanulságot, amelynek segítségével megakadályozható lenne, hogy ez az emberiség történetében újra és újra visszatérő jelenség elkerülhető legyen a jövőben.

A tanulság levonásához arra van szükség, hogy a szakértők a korábbi esetek komparatív vizsgálatával igyekezzenek meghatározni a népirtások jövőbeni előfordulási

\footnotetext{
175 Lyons, Leonard [1947]: Washington Post, 1947 January 30, Loose-Leaf Notebook, Page 9, Washington, D.C. (ProQuest Historical Newspapers), valamint Salt Lake Tribune, Lyons Den, Page 8, Column 3, Salt Lake City. (NewspaperArchive)

${ }^{176}$ Slovic, Paul [2007a]: Numbed by numbers, Never again? Its not lack of compassion that holds us back from stopping genocide, http://www.foreignpolicy.com/articles/2007/03/12/numbed_ by_numbers, valamint Lehrer, Jonah [2007]: The Psychology of Genocide In: The Frontal Cortex, April 13, 2007, http://scienceblogs.com/cortex/2007/04/the_psychology_of_genocide.php [2012.02.29.]

${ }_{177}$ Michel-Kerjan,Erwann;Slovic, Paul[2010]: The Irrational Economist, PublicAffairs. Slovic, PaulThe More Who Die, the Less We Care, 30-41.old.

${ }^{178}$ Slovic, Paul[2007b]: "If I look at the mass I will never act":Psychic numbing and genocide, In: Judgment and Decision Making, vol. 2, no. 2, April 2007, pp. 79-95.
} 
valószínüségét. A nyolcvanas évektől kezdve a társadalomtudósok komparatív vizsgálatokba kezdtek ${ }^{179}$, bizonyítékokat gyüjtöttek múltbeli és folyó ügyekről, és igyekeztek magyarázatot találni a kiváltó okok meghatározásával.

Ezen a területen úttörő munkát végzett BARBARA HARFF, aki több száz népirtást és politikai tömeges emberölést vizsgált meg, és kvantitatív analízisnek vetette alá a különböző eseteket. BARBARA HARFF nem csak következetes statisztikai módszereiről és hatalmas adatbázisáról híres, hanem a politicídium szó megalkotása kapcsán is. Harff úgy gondolja, hogy mivel a Genocídium-egyezmény definíciója nem alkalmas a politikai tömegmészárlások leírására, márpedig az adatgyüjtés fázisa során arra a következtetésre jutott, hogy „ritka az igazi genocídium”, a legtöbb eset valójában politicídium, ezért új definíciót alkotott. HARFF szerint politicídium alatt a következőt kell érteni: „A kormányzó elit vagy megbízottaik (illetve polgárháború esetén a harcoló felek bármelyike) olyan politikai módszereket segítenek, hajtanak végre vagy adják hozzájuk a hallgatólagos beleegyezésüket, amelyek célja közösségi, politikai vagy átpolitizált közösségi csoportok egészének, vagy jelentős részének kiirtása. [...] Népirtás esetén az áldozatok csoportját elsődlegesen közösségi jellemzőik alapján definiálják. Politicídium esetén ellenben a domináns csoport vagy uralkodó rezsim elleni politikai ellenállás alapján határozzák meg a csoportokat."180

HARFF a politicídiumokat és genocídiumokat a továbbiakban együttesen vizsgálta és ennek alapján vonta le következtetéseit. Hat kulcsfontosságú tényezőt emelt ki, amelyek valószínűbbé teszik népirtás, illetve politicídium elkövetését: politikai felfordulás, korábbi népirtások, az irányítók kirekesztő ideológiája és az uralkodó rezsim autokratikus jellege, etnikailag vagy vallási szempontból megosztott társadalom, alacsony gazdasági fejlettség, nemzetközileg elzárkózó ország.

\footnotetext{
${ }^{179}$ Fein, Helen.[1979]: Accounting for Genocide: National Responses and Jewish Victimization during the Holocaust. New York: Free Press; Fein, Helen [1984]: Scenarios of Genocide: Models of Genocide and Critical Responses., In Toward the Understanding and Prevention of Genocide: Proceedings of the International Conference on the Holocaust and Genocide, ed. Israel W. Charny. Boulder, CO: Westview Press, 3-31.; Fein, Helen [1993a]: Accounting for Genocide After 1945: Theories and Some Findings., In: International Journal on Group Rights 1, 79-106.old.; Fein, Helen [1993b]: Genocide: A Sociological Perspective. London and Newbury Park, CA: Sage; Harff, Barbara [1987]: "The Etiology of Genocide." In The Age of Genocide, ed. Michael N. Dobkowski and Isador Wallimann. Westport, CT: Greenwood Press, 41-59. old.; Harff, Barbara[1992]: Recognizing Genocides and Politicides., In Genocide Watch, ed. Helen Fein. New Haven, CT: Yale University Press, 27-41. old.; Kuper, Leo [1981]:Genocide: Its Political Use in the Twentieth Century. New Haven, CT: Yale University Press; Melson, Robert [1992]: Revolution and Genocide. Chicago: University of Chicago Press

${ }^{180}$ A German-born Genocide Scholar In: Totten, Samuel; Jacobs, Steven Leonard [eds, 2002]: Pioneers of Genocide Studies, New Brunswick (NJ): Transaction Publishers, 106.old.
} 
Némileg más oldalról közelíti meg a kérdést ERIC D. WEITZ, aki A Century of Genocide: Utopias of Race and Nation címü könyvében ${ }^{181}$ négy esetet hasonlít össze a huszadik században: a náci Németországot, a Szovjetunióban Lenin és Sztálin idejében elkövetett atrocitásokat, a vörös khmerek uralmát Kambodzsában, valamint az egykori Jugoszlávia területén elkövetett népirtást. Könyvében részletesen elemzi az egyes esetek hasonlóságait és különbségeit. WEITZ szerint a tárgyalt atrocitások közös vonásai a következők:

1. A közvetlen cél egy utópisztikus állam kiépítése, amely homogén, felsőbbrendü társadalomra épül. Ez a felsőbbrendü cél jogosítja fel az államot arra, hogy megszabaduljon az alacsonyabb rendünek tekintett emberektől, akik akadályozhatják a cél elérését, vagy fenyegetést jelentenek.

2. Különböző szigorú kritériumok alapján osztályozzák a lakosságot, ennek lényege, hogy egy vagy több lenézett csoportot is kialakítanak

3. A népirtást fokozatosan vezetik be a köztudatba, a diszkriminált és kirekesztett áldozati csoportot különféle rágalmakkal illetik. Eleinte csak szórványos atrocitások történnek, míg előkészítik a terepet a teljes „megtisztításra”.

4. Fokozatos elmozdulás a szórványos erőszakos cselekményektől a szervezett és szisztematikus népirtás felé, mivel hosszú időbe telik logisztikai és érzelmi szempontból felkészíteni rá az országot.

Robert Gellately és Ben KIERnAN The Specter of Genocide ${ }^{182}$ c. antológiájukban szintén arra keresnek választ, hogy mely tényezők valószínüsítik népirtás bekövetkeztét egy adott országban. Kutatásuk eredményeként megállapítják, hogy számtalan politikai és szociális tényező hathat katalizátorként: többek között történelmi sérelmek, erős előítéletek, ősi ellenségeskedés, arrogáns elit, amely a széleskörü szegénység ellenére folyamatosan gyarapodik, rossz irányítási struktúrák, fejletlen oktatás, gyors és nagy horderejü politikai, szociális vagy gazdasági változások, korábbi gyarmati státusz, háború, forradalom. Ezek a tényezők természetesen különböző arányban lehetnek jelen az egyes országokban, gyakran egymást erősítve.

\footnotetext{
${ }^{181}$ Weitz, Eric D.[2005]: A century of genocide: utopias of race and nation, Princeton University Press

182 Gellately, Robert; Kiernan, Ben (ed., 2003): The Specter of Genocide: Mass Murder in Historical Perspective. New York, Cambridge University Press, 374-375.old.
} 
YEHUDA BAUER $^{183}$, aki a holokausztot vizsgálta, arra a következtetésre jutott, hogy a népirtáshoz a vezető elit, az értelmiség és a társadalom együttmüködésére van szükség, valamint nagyban hozzájárulhat az is, ha válságban van a társadalom. A német társadalom azért szavazott bizalmat a nemzetiszocialistáknak, hogy jobb Németországot hozzanak létre, amely nem küzd gazdasági problémákkal és társadalmi válsággal. Ezen utópia nevében, a már látens módon burjánzó általános rasszizmusra építve sikerülhetett áttörni a gyilkoláshoz kapcsolódó erkölcsi gátakat.

Ha az ember pszichológiai adottságait vizsgálva keresünk magyarázatot a genocídium jelenségére, szintén nehéz értelmezni a tömeges erőszakot. Hiszen a legtöbb ember alaptermészetéből fakadóan idegenkedik az emberöléstől. Az extrém erőszak általában ellentétes a család, a vallási közösség, a társadalom egészének értékrendjével. A történelem mégis azt igazolja, hogy bizonyos körülmények között az emberek többsége kondicionálható úgy, hogy emberölést kövessen el vagy tétlenül végignézze, amint valaki más emberölést követ el. Számos kutató próbált már magyarázatot találni erre a viselkedésre. JAMES WALLER ${ }^{184}$ professzor számos viselkedéskutató korábbi eredményeit is felhasználva arra jutott, hogy nehéz, frusztráló, esetleg megalázó körülmények között megerősödik az emberekben az a tudat, hogy a túlélés érdekében meg kell védeniük magukat, családjukat és szélesebb értelemben vett csoportjukat. Ilyenkor bünbakot keresnek, akit felelőssé tehetnek nehéz helyzetükért. A bünbak pedig sokszor egy „másik” csoport, amelyet a problémák forrásának tekintenek. Így válhat jogossá akár a bünbakok fizikai megsemmisítése is, állapította meg ERWIN STAUB ${ }^{185}$ szociálpszichológus már a nyolcvanas évek végén. Ha egy társadalomban látens módon ugyan, de régóta lenéznek és értéktelennek tartanak egy bizonyos csoportot, valamint a társadalom vezéregyéniségei a többség felsőbbrendüségét hirdetik, és ez a helyzet külső nehézségekkel társul (gazdasági visszaesés, politikai összeomlás vagy történelmi ellenségeskedés), máris „ideálisak” a feltételek a célcsoport elleni agresszív támadáshoz. Ezek a tényezők összefonódhatnak a felbujtó vezetőknek való engedelmesség tudatával, illetve a tömegpszichózis is növelheti az erőszak elfogadását.

\footnotetext{
${ }^{183}$ Bauer, Yehuda [1991]: Holocaust and Genocide: Some Comparisons. In: Lessons and Legacies: The Meaning of the Holocaust in a Changing World, ed. Hayes, Peter [1991] Northwestern University Press, 36-46.old.

${ }^{184}$ Waller, James [2007]: Becoming evil: how ordinary people commit genocide and mass killing. Oxford University Press

185 Staub, Ervin [1989]: The Roots of Evil: The Origins of Genocide and Other Group Violence. Cambridge, UK: Cambridge University Press
} 
DAVID HAMBURG ${ }^{186}$ kiemeli: az események fokozatosan követik egymást, amíg egy bizonyos közvetlen kiváltó ok elindítja a tényleges erőszakhullámot. Ehhez azonban szükséges egyrészt az erőteljes belső ellenállás hiánya, valamint a külföldi tiltakozás elmaradása (a szomszédos országok, illetve a nemzetközi közösség közönye) is. A társadalom lassan hozzászokik a célcsoport elleni elszigetelt erőszakos incidensekhez, amelyeknek nincsen vagy elenyésző a jogi következménye, így fokozatosan elfogadottá és mindennapivá válnak. Ez is csak akkor történhet meg, ha az erőszak által közvetlenül nem érintettek a célcsoport tagjain nem segítenek, és ellenkezésüknek nem adnak határozott hangot (belőlük lesznek a genocídium során a „szemlélők”).

Amikor a körülmények kedvezőtlenek, nagyon nehéz pozitív, tevékeny útra terelni egy társadalmat. Sokkal egyszerübb felelősöket keresve mások ellen fordulni, és azt sugallni, hogy a túléléshez el kell pusztítani a célcsoportot, és ha ez sikerül, dicsőséges új korszak következik. Ahhoz, hogy egy társadalom ezt az érvelést elfogadja, természetesen karizmatikus vezetőkre van szükség, akik mederbe terelik a rejtett indulatokat a tömeges erőszak megvalósításához.

Egy dolog biztos: a genocídium nem spontán folyamat. A társadalomban szunnyadó indulatok szervezett mederbe terelése a társadalom manipulálása révén valósul meg. A népirtásokat nem felindulásból követik el, hanem gondos szervezést igényelnek az elkövetők részéről. Bár az erőszakos cselekmények gyakran igen gyorsan eszkalálódnak, általában csak fokozatosan jutnak el arra a szintre, amikor már népirtásról beszélhetünk. Éppen ezért minden genocídiumnak vannak előjelei, amelyeket azonosítva sürgethetőek a megelőzés érdekében tett lépések. Az első fenyegetések felbukkanásától a népirtás megvalósulásáig hónapok, évek, évtizedek telhetnek el, ami elegendő idő lehet ahhoz, hogy a nemzetközi közösség megelőző lépéseket tegyen.

A népirtások előjeleit számos kutató vizsgálta. GREGORY STANTON ${ }^{187}$ nyolc jól elkülöníthető fázisra osztja a népirtások előjeleit, illetve bekövetkeztét, ezek a következők: osztályozás, megbélyegzés, dehumanizáció, szervezés, polarizálás, felkészülés, pusztítás, tagadás. Ugyanakkor RAUL HILBERG ${ }^{188}$, aki a holokausztot vizsgálta, a következő szakaszokat különíti el: meghatározás, értékek eltulajdonítása,

\footnotetext{
${ }^{186}$ Hamburg, David [2010]: Preventing genocide, Practical steps toward early detection and effective action. Paradigm Publishers, London

${ }^{187}$ Stanton, Gregory [1998]: The eight stages of genocide, Working Paper (GS 01) of the Yale Program in Genocide Studies in 1998, http://www.genocidewatch.org/images/8StagesBriefingpaper.pdf

${ }^{188}$ Hilberg, Raul [1985]: The Destruction of the European Jews, Holmes and Meier
} 
koncentráció és megsemmisítés. KURT JONASSOHN és KARIN SOLVEIG BJÖRNSON ${ }^{189}$ véleménye szerint a népirtások általános megelőző jeleinek felismeréséhez számtalan, kultúrákon és korokon átívelő esetnek a vizsgálata szükséges. Számos népirtás átfogó vizsgálata alapján a két szerző a népirtás előjelének tartja, ha a hivatalos szervek tömeges erőszakra utaló nyílt kijelentéseket tesznek, illetve ha menekültek tűnnek fel egy adott ország vagy régió szomszédságában. A menekültáradatot komoly előjelnek kell tekinteni, mert senki sem hagyja el az otthonát, ingatlan és ingó vagyonát, megszokott környezetét, hacsak nem az életét félti. Szintén aggodalomra adhat okot, ha új kormányrendeleteket, törvényeket fogadnak el, amelyek sértik bizonyos csoportok jogait (korlátozzák utazásaikat, pénzhez jutásukat). Gyanús lehet az is, ha a hivatalos szervek letagadnak bizonyos híreket. BRIDGET CONLEY-ZILNIC és SAMUEL ToTTEN ${ }^{190}$ az alábbi intő jeleket azonosította a szakirodalom kimerítő vizsgálata alapján: ellenséges propaganda, amelyet a kormány támogat; egy adott csoport megbélyegzése sztereotípiákkal; rosszindulatú vagy dehumanizáló kampány a csoport ellen a kormány vezetésével vagy hallgatólagos támogatásával; törvényi változások, amelyek megfosztják a csoportot alapvető jogaitól; a csoporttagok vagyonának eltulajdonítása; a csoport tagjait eltiltják bizonyos foglalkozások üzésétől. Közvetlenebb előjelek lehetnek a kényszerdeportálások, paramilitáris csoportok által elkövetett és nem büntetett tömeges atrocitások, emberölések.

Tény azonban, hogy minden népirtás más, így az egyes esetek előjelei is különbözhetnek. A számtalan kutatás ellenére még nem sikerült olyan modellt találni, amely megbízhatóan jelezné előre a bekövetkező genocídiumot. A legnehezebb feladat talán észrevenni, hogy mely politikai vezetők akarják és rendelkeznek is a megfelelő eszközökkel a népirtás végrehajtásához. A szélsőséges csoportok befolyásának elemzése, valamint a veszélyeztetett régiókban napról napra változó politikai helyzet megfelelő elemzése ország-, illetve régióspecifikus ismereteket követel minden esetben.

Kérdéses, hogy kinek a feladata a figyelmeztető jelek értékelése? Milyen szervezetek alkalmasak a veszélyzónák megfigyelésére? Jelenleg különféle mértékben a média, nem-kormányzati szervek, az ENSZ egyes szervei, valamint a nemzeti kormányok is figyelik az előjeleket.

\footnotetext{
189 Jonassohn, Kurt; Björnson, Karin Solveig [1998]: Genocide and gross human rights violations in comparative perspective, Transaction Publishers

${ }^{190}$ Totten, Samuel; Parsons, William S.[2009]: Century of genocide: critical essays and eyewitness accounts, Routledge, chapter 18: Conley-Zilkic, Bridget; Totten, Samuel: The Challenges of Preventing and Responding to Genocide. 609-636.old.
} 


\subsection{Az előjelek értékelése, megelőzés, korai figyelmeztetés az ENSZ rendszerében}

A nemzetközi közösség alapvető képviselője az Egyesült Nemzetek Szervezete, amelynek számos szerve alkalmas lehet egy közelgő genocídiummal kapcsolatban figyelmeztető jelek leadására.

2004. április 7-én KOFI ANNAN akkori ENSZ-főtitkár a ruandai genocídium tizedik évfordulója alkalmából tartott genfi beszéde során bejelentette, hogy megalapítja a népirtás-megelőzési különleges tanácsadó hivatalát és egyben ötpontos akciótervet hirdetett meg. ${ }^{191}$ Az akcióterv lényege a következő:

a. a népirtásnak kedvező környezetet teremtő fegyveres konfliktusok megelözése

b. a fegyveres konfliktusok során meg kell védeni a civil lakosságot, ehhez az ENSZ békefenntartók mandátumát ki kell bővíteni

c. a nemzeti és nemzetközi bíróságok segítségével véget kell vetni a büntetlenség korszakának

d. az ENSZ népirtás-megelőzési különleges tanácsadójának az ENSZ Biztonsági Tanácsához intézett ajánlásai népirtások megelőzése vagy megállítása érdekében

e. gyors és határozott cselekvés egy meghatározott protokoll szerint, amely akár katonai intervenció is lehet, ha szükséges

2008-ban az ENSZ főtitkárának éves jelentésében értékelte a 2004-es célkitüzések alakulását és megállapította, hogy a népirtás és tömeges emberi jogi jogsértések területén a kockázatok kezelésének és a veszélyek elhárításának egyik legnagyobb akadálya az intézményi kapacitás hiánya (lack of institutional capacity). Új struktúrákat kell alapítani, vagy ,fókuszpontokat”, a világ különböző régióiban, amelyek a megelőzéshez müködési és strukturális eszközökkel is rendelkeznek. Ezen intézmények feladata az lenne, hogy információt gyüjtsenek és értékeljenek, folyamatosan ellenőrizzék az elmérgesedéssel fenyegető helyzeteket, felismerjék a genocídium és tömeges emberi jogi jogsértések bekövetkeztének kockázatát, valamint készítsenek megvalósítható alternatívákat nyújtó ajánlásokat a döntéshozók számára.

191 Press Release SG/SM/9197, AFR/893, HR/CN/1077 www.preventgenocide.org/prevent/UNdocs /KofiAnnansActionPlantoPreventGenocide7Apr2004.htm\#links [2011.09.20.] 
A kilencvenes években az ENSZ megelőző szervezetrendszere súlyos kudarcot vallott két esetben is. A ruandai népirtást követően egy független értékelö jelentés megállapította, hogy az ENSZ azért nem tudott hatékonyan fellépni, mert „,nem fektetett elég nagy hangsúlyt, vagy nem volt elegendő intézményi erőforrás a korai figyelmeztetésre és a kockázatelemzésre”, valamint az „ENSZ elemző képessége intézményi hiányosságok miatt" nem működött megfelelően. Ugyanez a jelentés felhívta a figyelmet arra, hogy az ENSZ-nek fejlesztenie kell az információkat elemző és arra reagáló képességét, valamint javítania kell az információáramlást a Biztonsági Tanács és az ENSZ egyéb szervei között az emberi jogi kérdésekben. ${ }^{192}$

A főtitkár Srebrenicáról készült jelentése ${ }^{193}$ az ENSZ müködésének más problémáit emelte ki. Megállapította, hogy a korai figyelmeztetés nem jelent egyben hatékony cselekvést is, de teljesebb és időben érkező jelentésekkel „a nemzetközi közösség talán kénytelen lett volna keményebben és gyorsabban reagálni és néhány életet talán meg lehetett volna menteni”. A jelentés azt is megállapította, hogy a szükséges információk hiánya az egész konfliktus során gondot okozott az ENSZ-nek, valamint a tagállamok szemére vetette, hogy rendelkezésre álló értesüléseiket nem osztották meg az ENSZszel.

Ezen súlyos kudarcokat követően az ENSZ prevenciós mechanizmusát és emberi jogi szervezetrendszerét az elmúlt években igyekeztek átalakítani az alábbi irányelveknek megfelelöen ${ }^{194}$ :

a. Az információáramlás legyen akadálytalan, az ENSZ egységes egészként reagáljon az információkra

b. ENSZ-tagállamok, regionális vagy szubregionális szervezetek, önálló szakértők vagy civil csoportok véleménye és információi segíthetik az ENSZ munkáját, de ezeket a védelem felelősségének elve195 mentén kell értékelni

c. A terepfeltételek óvatos, pontos és pártatlan értékelése folytán az adott helyzetre szabott korai és rugalmas válasz a cél. Az Alapokmány hatodik, hetedik és nyolcadik fejezetével összhangban minden elérhető

\footnotetext{
192 S/1999/1257. http://daccess-dds-ny.un.org/doc/UNDOC/GEN/N99/395/47/IMG/N9939547.pdf?Open Element, [2011.01.31.]

193 A /54/549, http://daccess-dds-ny.un.org/doc/UNDOC/GEN/N99/348/76/IMG/N9934876.pdf ?OpenElement, [2011.01.31.]

${ }^{194}$ A64/864: Early warning, assessment and the responsibility to protect. Report of the Secretary-General, http://www.un.org/ga/search/view_doc.asp?symbol=A/64/864. [2011.01.31.]

${ }^{195}$ A védelem felelősségéről részletesebben is lesz szó a negyedik fejezetben
} 
és szükséges politikai eszközt be kell vetni, a helyzet folyamatos változásához alkalmazkodva, hogy el lehessen kerülni a népirtást (valamint a háborús, az emberiesség elleni bünöket és az etnikai tisztogatást)

Ezen elvek létjogosultsága nem vonható kétségbe, és az ENSZ az elmúlt évtizedben valóban számos szervezeti változtatást hajtott végre a hatékonyság növelése érdekében.

A következőkben a megelőzéshez kapcsolódó ENSZ-szervek tevékenységét és mandátumát tárgyalom röviden az aktuális struktúra alapján. A gondolatmenet végén kitérek arra, hogy vajon ez a megelőző szervezetrendszer hatékonyabbá vált-e a kilencvenes évek kudarcaihoz képest, és alkalmas-e jelenleg az ENSZ egy népirtás megakadályozására.

\subsubsection{A népirtás-megelözési különleges tanácsadó és a védelem felelösségére koncentráló különleges megbízott hivatala}

Az ENSZ genocídiummal kapcsolatos legrelevánsabb szerve a népirtás-megelőzési különleges tanácsadó hivatala, amelyet 2004-ben alapítottak, a ruandai népirtás tizedik évfordulóján. KOFI ANNAN akkori ENSZ-főtitkár azzal a kifejezett szándékkal hozta létre a hivatalt, hogy adatokat gyüjtsön és folyamatosan ellenőrizze és megfigyelje az etnikai vagy rasszista dimenziójú tömeges emberi jogi jogsértéseket, amelyek népirtáshoz vezethetnek.

A népirtás-megelőzési tanácsadó hivatala viszonylag kevés embert foglalkoztat, mégis jelentős szereppel bír, hiszen közvetlenül a fötitkárhoz, illetve rajta keresztül a Biztonsági Tanácshoz fordulhat szükség esetén. A népirtás-megelőzési tanácsadó feladatköre a következőkre terjed ki: ${ }^{196}$

a. Az ENSZ-rendszeren belül már meglévő információ összegyűjtése a tömeges emberi és humanitárius jogi jogsértésekről, amelyek etnikai vagy faji okokból zajlanak, és amelyek esetleg genocídiumhoz vezethetnének.

b. Korai figyelmeztetés (early warning) a fötitkárnak, valamint rajta keresztül a Biztonsági Tanácsnak, figyelmük felhívása olyan ügyekre, amelyek népirtássá fajulhatnak

\footnotetext{
${ }^{196}$ http://www.un.org/en/preventgenocide/adviser/
} 
c. A fötitkár személyén keresztül ajánlások megfogalmazása a Biztonsági Tanács felé olyan akciókról, amelyek megelőzhetnek vagy megállíthatnak egy adott népirtást.

d. Konzultálás az ENSZ-szervekkel a népirtás megelőzésével kapcsolatos tevékenységekről, az ENSZ elemző és információkat rendszerező képességének javítása a népirtás és kapcsolódó büncselekmények tekintetében

A különleges megbízott feladatkörének kijelölése véleményem szerint arra utal, hogy az ENSZ nem információhiány miatt nem képes elősegíteni a hatékony megelőzést, hanem az összegyüjtött információ rendszerezése és becsatornázása, döntéshozókhoz juttatása jelenti a fő problémát.

Időközben a védelem felelősségének elve egyre nagyobb hangsúlyt kapott a nemzetközi rendszerben, szorosan összekapcsolódva a tömeges emberi jogi jogsértések és a népirtás megelőzésének kérdésével. Erre reflektálva BAN KI-MOON ENSZ-főtitkár 2007 decemberében létrehozta a védelem felelősségére koncentráló különleges megbízott hivatalát, és 2010-ben arra kérte a két (népirtás-megelőzéssel és védelem felelősségével foglalkozó) különleges megbízottat, hogy közös hivatalt alkotva dolgozzanak szorosan együtt. ${ }^{197}$ A védelem felelösségével foglalkozó különmegbízott feladata inkább elméleti, semmint gyakorlati jellegü. Feladata a fogalom pontosítása, beépítése a nemzetközi közgondolkodásba.

\subsubsection{Emberi Jogi Tanács}

A népirtások szempontjából szintén releváns ENSZ-szerv a Közgyülés által 2006. március 15-én létrehozott új Emberi Jogi Tanács, amely a korábbi ENSZ Emberi Jogok Bizottságát felváltja. Az új Tanács az emberi jogi válságokkal akkor foglalkozik, amikor azok felmerülnek. Nem úgy mint a Bizottság, amely évente egy hathetes ülésszakot tartott; az Emberi Jogi Tanács nem kevesebb, mint három ülésszakot tart évente, nem kevesebb mint tíz hétig összesen - továbbá rendkívüli sürgősségi ülésszakokat hirdethet bármikor tagjai egyharmadának a támogatásával. ${ }^{198}$

A Tanács egyik rendkívül hatékony eszköze lehet az előzetes figyelmeztetésre az ún. Egyetemes Időszakos Felülvizsgálat, amelynek keretében valamennyi ENSZ

\footnotetext{
${ }^{197}$ http://www.un.org/en/preventgenocide/adviser/responsibility.shtml

${ }^{198}$ Forrás: A magyar ENSZ Társaság honlapja
} 
tagállam emberi jogi helyzetét négyévente áttekintik. Az évente három, két hetes ülésszakon 48 ország esetében vizsgálja az EJT külön munkacsoportja az emberi jogok tiszteletben tartását, közben folyamatosan konzultál az adott ország képviselőivel. Az egyes országok helyzetének áttekintéséröl jelentés készül, amely tartalmazza az interaktív párbeszéd során elhangzottakat, ideértve a tagállamok által tett észrevételeket és ajánlásokat is. ${ }^{199}$ Az Emberi Jogi Tanácsnak továbbá lehetősége van arra is, hogy különleges ülést tartson a genocídium elkerülése vagy megállítása érdekében. 2006 decemberében került sor az első ilyen esetre az EJT történetében, amikor a folyamatban lévő darfúri atrocitások problémájának megtárgyalása érdekében különleges ülést hívtak össze. $^{200}$

Az EJT másik hatékony eszköze lehet a különleges előadók vagy különmegbízottak, illetve a különleges eljárások lehetősége, amelyek keretében bizonyos országokat, illetve emberi jogi jogsértéseket vehetnek górcső alá. A különleges eljárásokkal szemben azonban számos ország ellenvéleményt fogalmazott meg, rámutatva arra, hogy ezek átpolitizálhatják az EJT tevékenységét. ${ }^{201} \mathrm{~A}$ különmegbízottak közül a népirtás megelőzéséhez kapcsolódhat többek között a bírósági tárgyalás nélküli, azonnali vagy önkényes kivégzésekkel foglalkozó különmegbízott, illetve a kínzással foglalkozó különmegbízott, valamint a nők elleni erőszakkal foglalkozó különmegbízott tevékenysége.

\subsubsection{A Nemzetközi Bíróság, az Emberi Jogi és Menekültügyi Föbiztosság, valamint egyéb releváns szervek}

A Nemzetközi Bíróság szerepe szintén külön tárgyalandó a figyelmeztetéssel foglalkozó nemzetközi szervezetek körén belül, hiszen a Genocídium-egyezmény külön említést tesz róla. A kilencedik cikk elöírja, hogy az egyezmény értelmezésével, alkalmazásával vagy teljesítésével kapcsolatos kérdésekben a Nemzetközi Bírósághoz kell fordulni. A felelősségre vonástól tartva a kilencedik cikkel szemben számos ország fenntartást fogalmazott meg. ${ }^{202}$ Az egyezménnyel kapcsolatos legfontosabb jogeset a korábban már

\footnotetext{
${ }^{199}$ Forrás: A magyar Külügyminisztérium honlapja

200 Report on the Fourth Special Session of the Human Rights Council, UN Doc. A/HRC/S-4/5, [2012.01.31.]

${ }^{201}$ Lakatos István: Az ENSZ Emberi Jogi Tanácsa: Vágyak és realitások. Fundamentum, 2007/1. szám. http://157.181.181.13/dokuk/07-01-06.pdf, [2012.01.29.]

${ }^{202}$ A Nemzetközi Bíróság a Genocid-egyezményhez füzött fenntartások ügyben adott tanácsadó véleménye 1951. május 28-án látott napvilágot, ennek lényege összefoglalóan és röviden: az az állam, amely a Genocídium-egyezményhez fenntartást füzött, és eme fenntartást az egyezmény egy vagy több
} 
említett, 1993-ban Bosznia-Hercegovina által Jugoszlávia ellen indított per, amelynek keretében a Bíróság 1993-ban ideiglenes intézkedések ${ }^{203}$ foganatosítására szólította fel Jugoszláviát, ezeket azonban Jugoszlávia figyelmen kívül hagyta, így ez a lépés nem bizonyult elegendőnek a Srebrenicában 1995-ben lezajlott népirtás megelőzéséhez.

A Politikai Ügyek Osztálya, melynek fő megbízatása a konfliktus-megelőzés és békekötés, szintén jelentős szerepet játszhat a népirtások megelőzésében, főleg az egyes országokkal, illetve régiókkal foglalkozó osztályai, a különleges politikai missziói, valamint a választások lebonyolítását segítő munkacsoportjai révén. Regionális jelenléte miatt kulcsszerepe van továbbá a politikai fejlemények folyamatos figyelésében és értékelésében, valamint a békét elősegítő programok kidolgozásában.

A Humanitárius Ügyek Koordinációs Hivatalának humanitárius vészhelyzeteket értékelő kvantitatív és kvalitatív mutatói szintén segíthetik a veszélyzónák megfigyelését.

A különböző tevékenységi körrel rendelkező szervek munkáját igyekszik összehangolni az ENSZ Ügynökségek Közötti Keretterv a Megelőző Akciók Összehangolásáért (United Nations Interagency Framework for Coordination on Preventive Action), amely 21 ENSZ-szerv, osztály, alap és program tevékenységét egyezteti informális egyeztető fórumokon keresztül. A Keretterv olyan helyzeteket vizsgál, amelyek a növekvő feszültség korai jeleit mutatják.

Az ENSZ Emberi Jogi Főbiztossága, valamint a Menekültügyi Főbiztosság szintén folyamatosan ellenőrzik a mandátumukhoz kapcsolódó részterületeket, így aktív részesei a megelőzés rendszerének az ENSZ-en belül. Az emberi jogi főbiztos a legfőbb emberi jogokkal foglalkozó tisztviselő az ENSZ rendszerén belül, az ENSZ emberi jogokért tett erőfeszítéseinek vezetője. Jelenleg ezt a posztot NAVANETHEM PILLAY tölti be, aki korábban nyolc évig a Ruandai Nemzetközi Büntetőtörvényszék tagja, ebből négy évig az elnöke volt, tehát szívén viseli a népirtások megelőzésének kérdését. Ahogy népirtással foglalkozó gyakori nyilatkozatai egyikében fogalmazott: „A népirtás

\footnotetext{
más részes állama ellenezte, akkor tekinthető az egyezmény részes államának, ha fenntartása összeegyeztethető az egyezmény céljával és tárgyával. Forrás: http://www.icjcij.org/docket/files/12/4283.pdf, Advisory Opinion of 28 May 1951

${ }^{203}$ Hoffmann Tamás [2006]: Egy előre meghozott ítélet krónikája? A Népirtás büntettének megelőzéséről és megbüntetéséröl szóló egyezmény alkalmazása (Bosznia és Hercegovina kontra Szerbia és Montenegró) ügy a hágai Nemzetközi Bíróság elött, Kül-Világ, III. évfolyam. 2006/2.
} 
a diszkrimináció legvégső formája. Mindent meg kell tennünk, ami hatalmunkban áll, hogy megelőzzük."204

A Menekültügyi Föbiztosság a menekültek mozgását is figyeli. Mivel néha a menekültáradat megindulása jelzi a közelgő vagy már zajló népirtást, a Menekültügyi Főbiztosság értesülései is hozzájárulhatnak a korai figyelmeztetéshez. A szerv feladata továbbá az is, hogy a népirtások elől menekülőket biztonságba helyezze egy olyan országban, amelynek nem állampolgárai, tehát a szokásos állampolgári jogok nem illetik meg. A menekültügyi föbiztosok nem hagyják figyelmen kívül a menekültek és a népirtás kapcsolatát, erről tanúskodik többek között SADAKO OGATA akkori menekültügyi főbiztos 1997-ben tartott beszéde, amelyben így fogalmazott: „Az első kérdés: Eleget teszünk-e az új népirtások megelőzése érdekében? A második: Eleget teszünk-e azért, hogy legalább akik elmenekülnek a népirtások elöl, biztonságot és védelmet találjanak? [...] Attól félek, a válasz nem."205

Szintén fontos szerepet játszhatnak a megelőzésben az ENSZ emberi jogi egyezményeinek végrehajtása érdekében felállított szakértői testületek (ún. treaty bodies). ${ }^{206}$ Ahogy erről már korábban is történt említés, ezen szakértői bizottságok lényege, hogy a szerződés részes tagállamait folyamatos megfigyelésnek, illetve időközönkénti felülvizsgálatnak vetik alá. Jelenleg kilenc ilyen testület létezik, ezek közül a népirtás megelőzéséhez kapcsolódhat tevékenységében az Emberi Jogi Bizottság (Human Rights Committee), a Faji Diszkrimináció Elleni Bizottság (Committee on the Elimination of Racial Discrimination), a Kínzás Elleni Bizottság (The Committee Against Torture), valamint az Erőszakos Eltüntetések Elleni Bizottság (Committee on Enforced Disappearance). Ezek a testületek a vonatkozó egyezmény értelmében a részes tagállamok jelentései alapján követik az egyezményben foglalt jogok tiszteletben tartását. A részes államok általában a szerződéshez való csatlakozás után egy évvel kötelesek benyújtani első jelentésüket, majd bizonyos, a szerződés által elöírt időközönként (általában négy-ötévenként) ismételten értékelniük kell a vonatkozó helyzetet saját országukban. A kormányjelentésen felül az ellenőrző bizottságok más szervektől is szerezhetnek információkat az egy adott országban kialakult helyzetről,

204 Prevention and punishment are key $-60^{\text {th }}$ anniversary of the Genocide Convention. http://www.ohchr.org, December 2008,[2012.02.02.]

205 "Preventing Future Genocide and Protecting Refugees" - Address by Mrs. Sadako Ogata, United Nations High Commissioner for Refugees, at the Holocaust Memorial Museum, Washington, D.C., 30 April 1997. http://www.unhcr.org/cgi-bin/texis/vtx/search?page=search\&docid=3ae68fbc20\&query =genocide [2012.02.02.]

${ }^{206}$ Schabas, William [2007]: Preventing the Odious Scourge: The United Nations and the Prevention of Genocide International Journal on Minority and Group Rights 14, 392.old. 
például nem-kormányzati szervektől, más ENSZ-szervektől, kutatóintézetektől vagy akár a sajtótól. A megszerzett információk tükrében, a kormánytisztviselőkkel való konzultáció után a bizottság megfogalmazza aggodalmait és ajánlásait. Ahogy arról már korábban említést tettem, a Genocídium-egyezmény nem írja elő szakértői testület felállítását az egyezményben foglaltak betartásának ellenőrzésére. Természetesen más szakértői testületek is megfogalmazhatnak népirtás megelőzésével kapcsolatos aggályokat és ajánlásokat, azonban a genocídium-specifikus, egyezményhez kapcsolódó folyamatos ellenőrzés egyelöre nem kiépített a szerződés aláíró országaiban.

\subsubsection{Mi az oka a megelőzés sikertelenségének?}

A fentiek alapján nyilvánvaló, hogy az ENSZ látszólag elegendő erőforrással rendelkezik az információgyüjtésre és elemzésre. A kilencvenes évek csúfos bukásai után mégsem könyvelhető el sikerként a darfúri népirtásra adott ENSZ-reakció.

A 2003-ban egyre tömegesebbé váló atrocitások minősítésére az ENSZ vizsgálóbizottságot küldött Szudánba, amely 2005 elején megállapította, hogy a szudáni kormány nem népirtást követ el, hanem válogatás nélküli, a civileket sem kímélő támadásokat hajt végre a dzsandzsavid milíciákkal karöltve. Ezek a támadások a vizsgálóbizottság jelentése szerint nem nélkülözték a kínzásokat, erőszakos eltüntetéseket, falvak elpusztítását, nemi erőszakot vagy a fosztogatást sem. A nemzetközi beavatkozás a jelentés ellenére jó ideig elmaradt. Az Afrikai Unió 2006-ban küldött békefenntartó missziót Szudánba, amelyet 2008-tól az Afrikai Unió és az ENSZ közös, hibrid hadereje váltott fel, amely jelenleg a legnagyobb békefenntartó misszió a világon. ${ }^{207}$

Darfúr esetében már semmiképp sem takarózhat információhiánnyal, az információáramlás elégtelenségével, vagy a rendelkezésre álló információk nem megfelelő elemzésével az Egyesült Nemzetek Szervezete. Mi lehet a magyarázat arra, hogy a szükséges információk birtokában ezúttal sem sikerült elkerülni a népirtást?

A problémát a korai figyelmeztetés és a korai közbelépés közötti ür jelenti. Az információ megszerzése, elemzése és a figyelmeztetés nem okoz problémát, azonban amikor aktív közbelépésre lenne szükség (például katonai beavatkozásra), az ENSZ elkésik.

A megelőzés többek között azért ütközik nehézségekbe, mert mind a főtitkár, mind a Biztonsági Tanács hajlamosabb a túlterheltség miatt a már javában folyó

${ }^{207} \mathrm{http} / / /$ www.unis.unvienna.org/pdf/UN-Darfur_fact_sheet.pdf, [2012.02.01.] 
konfliktusokkal foglalkozni, semmint a megelőzésre fókuszálni. Szintén hátráltatja az aktív beavatkozást a Biztonsági Tanács állandó tagjainak vétójoga. Az állandó tagok szavazatát politikai érdekek befolyásolják. A nagyhatalmak általában vonakodnak csapatokat küldeni olyan térségekbe, ahol nem érzik veszélyeztetve érdekeiket. Ha ennek épp az ellenkezője igaz, azaz közvetlenül érintettek a konfliktusban, akkor ellentétes érdekeik akadályozhatják a konszenzust igénylö közbelépést. A megelőzés ellen hat továbbá, hogy az ENSZ Alapokmány részletesen elöírja a beavatkozás, illetve nyomásgyakorlás eszközeit az államok közötti ellentétek esetére, ugyanez viszont nem mondható el az államon belüli ellentétekről. A konkrét megelőző hadmozdulatok elindítását az is akadályozhatja, hogy a fejlett országok nem szívesen engedik át haderejüket közös ENSZ-fennhatóság alá, míg a harmadik világ országai a nemzeti szuverenitás elleni fenyegetésként élik meg a katonai beavatkozásokat.

Ennek ellenére az erőszak megelőzése széles körben elfogadottá vált. A jövőben valószínüleg azok a megelőzést célzó beavatkozások lehetnek sikeresek, ahol közös stratégiai cél az erőszak elkerülése, vagy ahol egy erős regionális hatalom veszi kézbe az akció levezénylését (például Kelet-Timor esetén Ausztrália). ${ }^{208}$

Az ENSZ intézményrendszere a fent említett okokból eredően jelenleg nem alkalmas a népirtás megelőzésére, illetve már folyamatban lévő atrocitások eszkalálódásának megakadályozására. A népirtás-megelőzési különleges tanácsadó hivatala példa nélküli előrelépés, hiszen még soha nem volt kifejezetten a népirtás megelőzésével foglalkozó szerv az ENSZ rendszerén belül. Ennek ellenére az ENSZnek nem sikerült megakadályoznia a közelmúltban lezajlott darfúri népirtást. Ez a tény arra utal, hogy a Biztonsági Tanács, illetve a Közgyülés egyelőre nem alkalmas fórumok a népirtás megelőzésére. Bár számos ENSZ-szerv dolgozik a megelőzés érdekében, a tényleges beavatkozásnak általában útját állja néhány ellenkező tagállam vagy az egymással ellentétes politikai érdekek. Nem valószínü, hogy ez a helyzet a közeljövőben megváltozik.

\footnotetext{
${ }^{208}$ Hamburg, David [2010]: Preventing genocide, Practical steps toward early detection and effective action, Paradigm Publishers, London, 217.old.
} 


\subsection{Az előjelek értékelése az ENSZ rendszerén kívül, regionális és civil szervezetek szerepe a megelőzésben}

Az előjelek értékelésének összehangolt rendszerét már számos alkalommal igyekeztek kialakítani. A nemzeti érdekeket fenyegető tényezőkre való korai figyelmeztetés általában a nemzetbiztonsági hivatalok feladata. Az Amerikai Egyesült Államokban a CIA feladatkörét 1994-ben bővítették azzal, hogy elemezze az államokat genocídiumra hajlamosító tényezőket. ${ }^{209}$ Több kormány ${ }^{210}$ is finanszírozott korai figyelmeztetésre alkalmas rendszerek kidolgozását célzó programokat egyetemeken és kutatóintézetekben. A nem-kormányzati szervek Európa-szerte és Amerikában szintén sokat foglalkoznak a korai figyelmeztetéssel, kiemelendő az International Crisis Group, a Forum on Early Warning and Early Response (FEWER), a Genocide Watch és az International Campaign to End Genocide (különböző szervezetek nemzetközi egységszerve a népirtás megelőzéséért). ${ }^{211}$

A regionális szervezetek közül Magyarország szempontjából különösen releváns az Európai Unió. A második világháború után alapított Uniót sokan önmagában is az egyik leghatékonyabb megelőző szervnek tartják, hiszen a korábban Európa-szerte jellemző fegyveres konfliktusokat a tagok között felváltotta a partneri együttmüködés. Ahogy Timothy Garton Ash nemzetközi kapcsolatok szakértő fogalmazott: az elmúlt évszázad barbár élményeiből tanulva az európaiaknak kötelessége közbelépni, hogy megakadályozza a genocídiumot nem csak Európában, hanem az egész világon. ${ }^{212}$

Bár az Uniónak nincsen kifejezett közös álláspontja a népirtások megelőzéséröl, a konfliktusmegelőzés a Lisszaboni Szerződés értelmében az EU külső tevékenységének egyik legfontosabb eleme. Az erőszakos konfliktusok megelőzésére irányuló EUprogram (göteborgi program), amelyet az Európai Unió Tanácsa (Tanács) 2001-ben fogadott el, kiemeli a megelőző fellépés fontosságát. ${ }^{213}$ Az EU az azóta eltelt tíz évben folyamatosan erősítette a kapcsolatot a konfliktus-megelőzés kulcsfontosságú

\footnotetext{
${ }^{209}$ Stanton, Gregory [2009]: The Prevention of Genocide. In: Tottenham, Samuel; Bartrop, Paul R.: The Genocide Studies Reader, Routledge, 2009 319.old.

${ }^{210}$ Nagy-Britannia, Hollandia, Dánia, Svédország, Németország

${ }^{211}$ Stanton, Gregory [2009]: The Prevention of Genocide. In: Tottenham, Samuel; Bartrop, Paul R.: The Genocide Studies Reader, Routledge, 2009 319.old.

${ }^{212}$ Ash, Timothy Garton [2004]: Free World: America, Europe and the Surprising Future of the West, New York, Random House

213 Woollard, Catherine [2011]: European Peacebuilding Liaison Office Review of the Gothenburg Programme.

http://www.eplo.org/assets/files/2.\%20Activities/Working\%20Groups/EEAS/EPLO_Review_Gothenburg _Programme.pdf, [2012.02.29.]
} 
szereplőivel világszerte: az ENSZ-szel, a Világbankkal, az EBESZ-szel, a NATO-val, az Afrikai Unióval, valamint más regionális szervezetekkel, továbbá egyes országokkal.

A 2011-ben a Tanács 3101. ülése alkalmából kiadott sajtóközleményben az Unió megállapítja, hogy „A rövid és a hosszú távú megelőzést szolgáló uniós eszközöket elsősorban a Közös Biztonság- és Védelempolitika polgári és katonai ágának fejlesztésén, valamint a Stabilitási Eszköz létrehozásán keresztül - megerősítettük.”, az elmúlt évek erőfeszítéseinek eredményeként pedig az „EU már rendelkezik konfliktusmegelőzésre szolgáló eszközökkel”. ${ }^{214}$ A sajtóközlemény azonban kiemeli, hogy a korai előrejelzést tovább kell erősíteni, többek között az uniós küldöttségektől és a civil társadalmi szereplőktől kapott helyi információk fokozottabb felhasználása révén. Ahogy Riina Kionka, Javier Solana akkori emberi jogi megbízott szóvivője 2008-ban a Preventing genocide and mass atrocities-Our responsibility to prevent c. konferencián kifejtette ${ }^{215}$ : az EU erőssége a korai beavatkozás, a politikai és katonai eszközök együttes alkalmazása, és nem a hagyományos clausewitzi felfogás szerinti erőalkalmazás. A diplomáciai eszközök között különösen hatékony lehet a közvetítés: az EU a közvetítőknek és személyzetüknek biztosított támogatás és képzés, valamint készültségük fokozása révén tervezi tovább erősíteni a közvetítési kapacitását. ${ }^{216}$

Ha a nyomásgyakorlás eszközeit tekintjük át, az EU a hosszú távú megelőzést segítheti a fejlesztési együttmüködéseken keresztül, valamint a kereskedelem, fegyverzetellenőrzés, valamint kiterjedt emberi jogi párbeszéd révén is. A rövid távú megelőzéshez pedig diplomáciai és humanitárius eszközök széles spektruma áll rendelkezésére. $^{217}$

Ha az előző részben említett ENSZ-jelentésben javasolt fókuszpontokra gondolunk, akkor arra a következtetésre juthatunk, hogy az EU népirtás-megelőzési képességét nagyban javítaná egy regionális népirtás-megelőzési központ felállítása, amelynek feladata kifejezetten a népirtással és tömeges emberi jogi jogsértésekkel fenyegető helyzetek vizsgálata, és a döntéshozók figyelmeztetése lenne. 2008-ban merült fel egy megelőzési központ alakítása Budapesten, és 2012 második felében a Népirtás és

\footnotetext{
${ }^{214}$ Az EU Tanácsa, Sajtóközlemény. A Tanács 3101. ülése, Külügyek, Luxembourg, 2011. június 20. http://europa.eu/rapid/pressReleasesAction.do?reference=PRES/1 1/181\&format=HTML\&aged=1\&langu age $=$ HU\&guiLanguage $=$ en, [2012.02.29.]

215 "Preventing Genocide and Mass Atrocities: our Responsibility to Prevent" 13 March 2008, Brussels, The EU's Approach: Championing Human Rights, Engaging Preventively, 4. old. http://www.madariaga.org/images/madariagareports/2008-mar-13\%20-\%20preventing\%20genocide\% 20 and\%20 mass\%20atrocities\%20our\%20responsbility\%20to\%20prevent.pdf, [2012.02.29.]

${ }_{216}^{216}$ EU Tanács 3101. ülése, sajtóközlemény, Luxemburg, 2011. június 20.

${ }^{217}$ Hamburg, David [2010]: Preventing genocide, Paradigm Publishers, 231.old.
} 
Tömeges Emberi Jogi Jogsértések Nemzetközi Megelőzésének Központja megkezdte működését. ${ }^{218}$ A Központ népirtás-megelőzésben betöltött szerepét a hatodik fejezetben részletesen tárgyalom.

Az ötödik fejezetben vizsgált esettanulmányok az afrikai Nagy Tavak Régió környékére fókuszálnak, ezért a disszertációban különös figyelmet szentelek a régió népirtás-megelőzési erőfeszítéseinek. Kiemelem a Nagy Tavak Régiójának Nemzetközi Konferenciáját (International Conference on the Great Lakes Region), amelyet 2004ben alapítottak, és amely jelentős figyelmet szentel a népirtás megelőzésének és megbüntetésének. 2006-ban tizenegy tagország képviselői egyezményt írtak alá a népirtás, háborús és emberiesség elleni bünök megelőzéséről és megbüntetéséről, majd 2010-ben megalakították az egyezmény ellenőrző bizottságát (treaty body). ${ }^{219}$ A Konferencia együttműködési szerződést írt alá a budapesti Központtal is. Tevékenységét az esettanulmányok tárgyalása után, a hatodik fejezetben elemzem.

A harmadik fejezetben részletesen tárgyaltam az előjelek értékelésére és a figyelmeztetésre szakosodott nemzetközi szervezetek szerepét a megelözésben. Az eddigiek során azonban nem esett szó a megelőzés kapcsán felmerülő gyakorlati teendőkről, illetve a megelőzés miatti intervenció jogalapjáról. A következő fejezet témája a védelem felelősségének elve.

\section{4. fejezet: A védelem felelőssége}

Egy másik ország területén zajló népirtás megakadályozásához kisebb-nagyobb mértékü intervencióra van szükség. Az intervenció számos kérdést vet fel. Más szuverén ország belügyeibe avatkozni ellentétes az ENSZ elveivel, ${ }^{20}$ amelyek értelmében minden országnak kötelessége tiszteletben tartani egy másik ország szuverenitását, és ennek keretében ahhoz való jogát, hogy saját ügyeit önállóan kezelhesse.

A kilencvenes évek ruandai és balkáni eseményei komoly vitákat generáltak a nemzetközi közösség berkeiben arról, hogy hogyan lehet hatékonyan reagálni olyan esetekben, amikor egy országban az ott élök emberi jogait tömegesen és szisztematikusan megsértik. Természetesen a viták kereszttüzében az állami

\footnotetext{
218 http://www.genocideprevention.eu

${ }^{219}$ www.icglr.org

${ }^{220}$ Az ENSZ alapokmánya a non-intervenció elvét kifejezetten, expressis verbis csak az ENSZ és tagállamai közötti viszonyra mondja ki, az állam-állam közti viszonyrendszer esetében azonban csak kiolvasható a beavatkozás tilalma, olyan cikkelyekből, mint a szuverén egyenlőség elvét vagy az erőszak tilalmát rögzítő rendelkezések.
} 
szuverenitás állt: az egyes államok vajon feltétel nélkül ragaszkodhatnak-e föhatalmukhoz, vagy a nemzetközi közösségnek jogában áll humanitárius okokból beavatkozást eszközölni. ${ }^{221}$ 2000-ben KoFI ANNAN ENSZ-főtitkár azt a kérdést szegezte a nemzetközi közösség képviselöinek, hogy ha az atrocitások megakadályozásához szükséges intervenció ,a szuverenitás elleni elfogadhatatlan támadás”, akkor hogyan reagáljon a világ egy újabb Ruandára, Srebrenicára. ${ }^{222}$

\subsection{Az elv kialakulása és nemzetközi jogi elfogadottságának alakulása}

Erre a kérdésre próbált megoldást találni az Intervenció és Állami Szuverenitás Nemzetközi Bizottsága ${ }^{223}$ (továbbiakban: Bizottság vagy ICISS), amely a kanadai kormány égisze alatt jött létre 2000-ben. A kanadai miniszterelnök a 2000. szeptemberi millenniumi ENSZ-Közgyülésen jelentette be, hogy Kanada független bizottságot hoz létre annak érdekében, hogy megkönnyítsék a nemzetközi konszenzust az emberi és humanitárius jogok tömeges megsértésére való egységes válaszadás tekintetében. ${ }^{224} \mathrm{~A}$ Bizottsággal szemben az volt a nemzetközi elvárás, hogy békítse ki a látszólag összeegyeztethetetlen ,állami szuverenitás” és „,beavatkozás” fogalmakat. ${ }^{225}$

2001 februárjában a bizottság egyik ülése folyamán merült fel a javaslat, hogy a védelemre szoruló lakosság miatti beavatkozás kapcsán új kifejezést alkossanak. Mivel a „beavatkozás joga” (right to intervene) jogilag ugyan logikus választás lett volna, azonban az állami szuverenitást sértő jellege miatt valószínüleg nem fogadták volna el, lekerült a napirendről. Felmerült még a „beavatkozás kötelessége” (obligation to intervene), mivel mindenképpen hangsúlyozni akarták a nemzetközi közösség felelősségét, ha tömeges emberi jogi jogsértésekről van szó. Azonban ez azt is jelentette volna, hogy a nemzetközi közösségnek nincs más választása, mint az erő alkalmazása, ha az atrocitások mértéke átlépett egy bizonyos küszöböt.

2001 februárjában a „,védelem felelőssége” (responsibility to protect, vagy rövidítve R2P) elnevezést a megbeszélésen részt vevő Gareth Evans, Mohamed Sahnoun és

\footnotetext{
${ }^{221}$ Lessons from Rwanda, the United Nations and the Prevention of Genocide. http://www.un.org /preventgenocide/rwanda/responsibility.shtml, [2011.01.26.]

${ }^{222}$ UN Millennium Report 2000, Chapter 3: Freedom from fear, 48.old.

${ }^{223}$ International Commission on Intervention and State Sovereignty

${ }^{224}$ Hubert, Don; Weiss, Thomas G. [2001] : The Responsibility to protect: Research, bibliography, background Supplementary Volume to the Report of the International Commission on Intervention and State Sovereignty About the Commission, http://web.idrc.ca/en/ev-28644-201-1-DO_TOPIC.html [2012. 02 12.]

${ }^{225}$ Ibid.
} 
Michael Ignatieff ${ }^{226}$ javasolta, és nézetüket alá is támasztották a Bizottság 2001-ben megjelent, azóta elhíresült jelentésében, melynek címe Responsibility to Protect (A védelem felelőssége). ${ }^{227} \mathrm{~A}$,védelem felelőssége” nemcsak az elnevezés, hanem a nemzetközi közösség perspektívájának változását jelentette. A korábbi, beavatkozást fontolgatók szemszögéből felvetett kérdéseket a bizottság szerint a továbbiakban a védelemre szorulók szemszögéből érdemes vizsgálni. A „védelem felelőssége” nem csak a reagálás felelősségét, hanem a megelőzés és újjáépítés felelősségét is magában foglalja, ráirányítja a figyelmet a passzivitás költségeire az aktív fellépéssel szemben, normatív és operacionális kapcsolatot teremt a segítségnyújtás, beavatkozás és újjáépítés között. ${ }^{228}$

A jelentés hangsúlyozta, hogy ahol a lakosságot komoly veszély fenyegeti, amelyet az állam nem képes, vagy nem akar megakadályozni, ott a non-intervenció szabályát felülírja a védelem felelőssége.

A jelentés kiemelte, hogy a védelem felelőssége elv alapját képezi egyrészt maga az állami szuverenitás, másrészt a Biztonsági Tanács nemzetközi békéért és biztonságért való felelőssége az ENSZ Alapokmány 24. cikke alapján. Szintén felelösséget keletkeztetnek a különböző emberi jogi határozatok és nemzetközi szerződések. A védelem felelősségének irányába mutat számos ország, valamint regionális szervezetek és a Biztonsági Tanács gyakorlata is.

A jelentés megállapította, hogy a szuverenitás nem csak főhatalom, hanem egyben felelősség is, és a nemzetközi közösségnek felelőssége, hogy megelőzze a tömeges atrocitásokat. Ennek érdekében gazdasági, politikai és társadalmi intézkedéseket is érdemes bevetni, valamint a teljes diplomáciai eszköztárat, ha szükséges. A katonai beavatkozást a jelentés utolsó lehetőségként említette, de részletesen tárgyalta, hogy milyen kritériumok esetén valósulhat meg. A jelentés alapján a védelem felelősségének részét képezi az újjáépítés is, amely összetett fogalom: magában foglalja a biztonságos környezet kialakítását, a bünösök felelősségre vonását és a tömeges atrocitások okainak feltárását.

\footnotetext{
${ }^{226}$ Haines, Steven; Kassimeris, George, ed. [2010], Chapter 18, Humanitarian Intervention: Genocide, Crimes against Humanity and the Use of Force, The Ashgate research companion to modern warfare, Burlington, VT: Ashgate Publishing Ltd. 323.o.

${ }^{227}$ International Commission on Intervention and State Sovereignty (2001): The Responsibility to Protect. Ottawa, Canada, the International Development Research Centre, http://web.idrc.ca/en/ev-28738-201-1DO_TOPIC.html [2012.február 12.]

${ }^{228}$ Ibid. 2.29
} 
A védelem felelősségének három fő eleme tehát: a megelőzés, a reakció és az újjáépítés felelössége. Ezek közül a fő elem a megelőzés, amelynek minden elemét ki kell meríteni mielőtt a beavatkozást fontolóra veszik. A jelentés kiemelte továbbá, hogy nagyobb mértékü kötelezettségvállalásra van szükség a megelőzés terén, anyagilag és erkölcsileg egyaránt.

A jelentés 2001. decemberi időzítése nem volt túl szerencsés, mivel a 2001. szeptember 11-i terrortámadás után a világ figyelme sokkal inkább a terrorizmus megelözése, valamint a tömegpusztító fegyverek proliferációjának megakadályozása felé fordult. Irak 2003-as lerohanása, amelyet részben humanitárius intervenciónak is aposztrofáltak, szintén nem tett jót a védelem felelössége szélesebb körü támogatásának. Az iraki hadjárat csak erősítette az elvvel kapcsolatos azon aggályokat, hogy az elv a kisebb fejlődő országok szuverenitásának aláásására is szolgálhat. Azonban a kezdeti nehézségek ellenére a folytatódó humanitárius katasztrófák miatt, többek között Darfúrban, újra előtérbe került a nemzetközi közösség felelőssége, hogy megakadályozza a népirtást és más tömeges emberi jogi jogsértéseket. ${ }^{229}$

Az ICISS jelentésének tehát nem volt közvetlen hatása. Azonban 2003 szeptemberében az akkori ENSZ-főtitkár, Kofi Annan ismét felhívta a figyelmet arra, hogy az ENSZ számos alkalommal képtelen volt megfelelően reagálni a népirtásokra. Megbízta az újonnan alakított Fenyegetéseket, kihívásokat és változást vizsgáló magas szintű bizottságot (High-level Panel on Threats, Challenges and Change), hogy vizsgálja meg az ENSZ legégetőbb biztonságpolitikai kihívásait a 21. században. 2004 decemberében jelent meg A More Secure World: Our Shared Responsibility (Egy biztonságosabb világ: Közös felelősségünk) címmel ${ }^{230}$ a megbeszélések eredménye. Ebben a dokumentumban ismét kiemelték a nemzetközi közösség felelősségét, amikor társadalmakat súlyos fenyegetésektől kell megvédeni.

Nem sokkal később maga a főtitkár is megjelentetett egy beszámolót, amelyben felhívta a kormányok figyelmét, hogy fogadják el és támogassák a védelem felelőssége elvet. $^{231}$

Az Afrikai Uniónak kulcsszerepe volt az elv széleskörü nemzetközi elfogadottságának megteremtésében. Az Afrikai Unió alapító okiratában felhatalmazza tagjait a beavatkozásra- az Afrikai Unió Közgyülésének döntése alapján, ha egy

\footnotetext{
${ }^{229} \mathrm{http}: / /$ www.responsibilitytoprotect.org/index.php/about-rtop [2012. 02.14]

${ }^{230} \mathrm{http}: / / \mathrm{www} . u n . o r g /$ secureworld/ [2012.02.14.]

231 In Larger Freedom: Towards Development, Security and Human Rights for All. http://www.un.org/largerfreedom/ [2012.02.14.]
} 
tagállamban súlyos helyzet állt elő, azaz háborús büncselekmények, népirtás vagy emberiesség elleni bünök kapcsán. ${ }^{232}$ Igaz, hogy ez a felhatalmazás a teljes védelem felelőssége eszköztárnak csak az egyik végét, a katonai beavatkozást említi, azonban jól mutatja az afrikai országok elkötelezettségét a lakosság védelme tekintetében, még ha az egyes tagországok szuverenitását csorbítja. Az Afrikai Unió továbbá 2005-ben elfogadta az ENSZ reformjáról szóló közös afrikai álláspontot, amely „Ezulwini Konszenzusként" ${ }^{233}$ ismert. Ebben a dokumentumban az Afrikai Unió üdvözölte a védelem felelősségének elvét, és hangsúlyozta, hogy csak a Biztonsági Tanács rendelheti el erő alkalmazását. Azonban javasolta, hogy a regionális szervezetek, mivel esetleg jobban ismerik az adott helyzetet, avatkozhassanak be „utólagos jóváhagyással” (after the fact), ha sürgős a helyzet. Összességében is kiemelte a regionális szervezetek jelentőségét, és megerősítésük, jogkörük szélesítése mellett tört lándzsát.

A 2005-ös ENSZ-csúcs alkalmával tovább erősödött a védelem felelősségének elve. Ebben nagy szerepe volt annak, hogy a csúcs vezetői között ott volt Argentína, Chile, Guatemala, Mexikó, Ruanda és Dél-Afrika, akik mindannyian támogatták az elv melletti nyílt kiállást. Számos más országot is sikerült mozgósítaniuk és végül 2005 szeptemberében az ENSZ tagállamai egyöntetüen elfogadták a védelem felelősségének elvét. A világcsúcs záródokumentumának 138. és 139. paragrafusa a következőképpen fogalmaz:

„Minden önálló állam saját felelőssége, hogy megvédje lakosságát a népirtástól, háborús büncselekményektől, etnikai tisztogatástól és az emberiesség elleni büncselekményektől. [...] Elfogadjuk ezt a felelősséget, és ennek megfelelően fogunk cselekedni [...]. A nemzetközi közösségnek bátorítania, és segítenie kell az államokat ezen felelősségük gyakorlásában [...]. A nemzetközi közösségnek az ENSZ-en keresztül az is felelőssége, hogy a megfelelő diplomáciai, humanitárius és egyéb békés eszközöket bevesse az Alapokmány VI. és VIII. fejezete értelmében [...] annak érdekében, hogy a népeket megvédje a népirtástól, háborús büncselekményektől, etnikai tisztogatástól és az emberiesség elleni büncselekményektől. Ennek megfelelően felkészültünk a kollektív cselekvésre, amely megfelelő időben és határozottan zajlik majd a Biztonsági Tanácson keresztül, az Alapokmánnyal összhangban, beleértve a hetedik fejezetet; eseti alapon, a releváns regionális szervezetekkel együttmüködve-

\footnotetext{
${ }^{232} \mathrm{http} / / /$ au.int/en/sites/default/files/PROTOCOL_AMENDMENTS_CONSTITUTIVE_ACT_OF_THE_ AFRICAN_UNION.pdf , 4. cikkely (h) bekezdés [2012.02.14.]

${ }^{233}$ http://www.responsibilitytoprotect.org/AU_Ezulwini\%20Consensus.pdf [2012.02.14.]
} 
abban az esetben, ha a békés eszközök elégtelennek bizonyulnak és a nemzeti hatóságok nyilvánvalóan elmulasztják megvédeni lakosságukat a népirtástól, háborús bűncselekményektől, etnikai tisztogatástól és az emberiesség elleni bűntettektől.” 234

2005 óta a védelem felelőssége lassan, de biztosan halad az általánosan elfogadott normává válás felé. Az ENSZ Biztonsági Tanácsának a civilek fegyveres konfliktusokban történő védelméről szóló, 1674. sz. határozatát (2006) ${ }^{235}$ (amelyet hat hónap huzavona után, amelynek során eleinte Oroszország és Kína is úgy érveltek, hogy a BT-nek korai a kérdéssel foglalkozni) ${ }^{236}$ egyhangúlag elfogadták. Ez az első BThatározat, amely említi a védelem felelőssége elvet. Ugyanebben az évben az 1706. sz. BT-határozat $(2006)^{237}$ hivatkozott az 1674. sz. határozatra, valamint a 2005-ös csúcs záródokumentumának 138. és 139. paragrafusára. Azonban az egyes tagországok részéről tapasztalt diplomáciai nyomás és tartózkodás (Kína tartózkodott az 1706. határozat megszavazásánál) miatt 2006 után konkrét esetek kapcsán évekig nem merült fel a védelem felelősségének elve. Csak ún. tematikus, elméleti jellegü határozatokban foglalkoztak vele. ${ }^{238}$

Bár 2006-os kinevezése után sok, a védelem felelőssége iránt elkötelezett szakértő kritizálta BAN KI-MOONt, amiért kevéssé karizmatikus egyéniség, és olyan államokkal is tárgyalásokba kezd, amelyek emberi jogi helyzete sok kívánnivalót hagy maga után, a fötitkár sikeresen kivívta a védelem felelőssége elvének szélesebb körü elfogadását. ${ }^{239}$ 2008-ban Berlinben ${ }^{240}$ beszélt először a hárompilléres megközelítésröl, amelyet 2009-es A védelem felelősségének átültetése a gyakorlatba (Implementing the responsibility to protect) c. jelentésében ${ }^{241}$ részletesebben is kifejtett.

Az első pillér magának az államnak a felelőssége, hogy megvédje állampolgárait a népirtástól, etnikai tisztogatástól, háborús bünöktől, és emberiesség elleni bünöktől. A második pillér a nemzetközi közösségre háruló felelősség, hogy segítséget nyújtsanak

\footnotetext{
234 ENSZ Közgyülési Határozat, 60/1. 2005 World Summit Outcome, 30. oldal http://daccess-ddsny.un.org/doc/UNDOC/GEN/N05/487/60/PDF/N0548760.pdf?OpenElement, [2012.01.26.] [2012.02.15.] http://daccess-dds-ny.un.org/doc/UNDOC/GEN/N06/331/99/PDF/N0633199.pdf?OpenElement,

${ }^{236}$ Bellamy, Alex J. [2010]: The Responsibility to Protect- Five Years On Ethics and International Affairs, 24, No. 2., 143-169.o. Carnegie Council for Ethics in International Affairs

237 http://daccess-dds-ny.un.org/doc/UNDOC/GEN/N06/484/64/PDF/N0648464.pdf?OpenElement, [2012.02.15.]

${ }^{238}$ Bellamy [2010]

239 Thakur, Ramesh: The model of a mediocre secretary general [2009.10.25.], Ottawa Citizen. http://www.cigionline.org/articles/2009/09/model-mediocre-secretary-general, [2012.02.15.]

${ }^{240} \mathrm{http}$ ///www.un.org/News/Press/docs/2008/sgsm11701.doc.htm, [2012.02.15.]

${ }^{241} \mathrm{~A} / 63 / 677$. http://daccess-dds-ny.un.org/doc/UNDOC/GEN/N09/206/10/PDF/N0920610.pdf?Open Element [2012.02.16]
} 
az egyes államoknak a védelemhez szükséges kapacitások kiépítésében, valamint közelgő válsághelyzetek, illetve konfliktusok esetén, mielőtt rosszabbra fordul a helyzet. A harmadik pillér a nemzetközi közösség határozott és időben történő közbelépése a közelgő népirtás, etnikai tisztogatás, háborús bünök vagy emberiesség elleni bünök esetén, ha az állam nyilvánvalóan nem tesz eleget védelmi felelősségének.

2008-ban az ENSZ-főtitkár kinevezte Edward C. Luckot ${ }^{242}$ a lakosság népirtástól, etnikai tisztogatástól, háborús és emberiesség elleni büncselekményektől való védelmének felelösségére koncentráló különleges megbízottnak. A titulus körülményes elnevezése (eredetileg egyszerüen Special Adviser on the Responsibility to Protect lett volna) egyes tagállamok ellenkezésének az eredménye, akik egyrészt nem akarták finanszírozni ezt a hivatalt, másrészt azzal érveltek, hogy a 2005-ös csúcstalálkozó során sosem fogadták el egyöntetüen a védelem felelősségét mint normát. ${ }^{243} 2010$-ben az egymáshoz szorosan kapcsolódó népirtás-megelőzési és védelem felelősségével foglakozó különleges megbízottak hivatalát összevonták.

2009 júliusában az ENSZ Közgyülése megvitatta a védelem felelősségének elvét, első alkalommal a 2005-ös világcsúcs óta. A 63. évi Közgyülés egyik legnagyobb létszámú plenáris ülésén 94 felszólaló kommentálta mintegy 180 ország és megfigyelö álláspontját. $^{244} \mathrm{~A}$ tagállamok nagy része támogatta a fent említett négy büntény megelőzését és megakadályozását, csak négy ország (Venezuela, Kuba, Szudán és Nicaragua) jelezte, hogy a visszavonná a 2005-ös záródokumentumban foglaltakat. A legtöbb ENSZ-tagállam pozitívan értékelte a védelem felelősségének doktrínáját, amely sokak szerint az ENSZ céljainak megfelelő és a 21. század kihívásaira igyekszik választ adni. $^{245}$

A fötitkár a következő években is aktívan folytatta a védelem felelősségéért zajló kampányát. 2010-ben Korai figyelmeztetés, értékelés és a védelem felelőssége (Early warning, assessment and the responsibility to protect ${ }^{246}$ címen újabb jelentést írt. Ebben a dokumentumban BAN KI-MOON az ENSZ megelőzésre használható kapacitását és a hiányosságokat ismertette. Kiemeli, hogy az ENSZ nem küzd információhiánnyal,

\footnotetext{
${ }^{242}$ http://www.un.org/News/Press/docs/2008/sga1120.doc.htm,[2012.02.15.]

${ }^{243} \mathrm{http}$ ://www.responsibilitytoprotect.org/index.php/about-rtop/learn-about-rtop,[2012.02.15.]

244 Implementing the responsibility to protect. The 2009 General Assembly Debate: An Assessment [2009] GCR2P Report. Global Centre for the Responsibility to Protect, Ralph Bunche Institute for International Studies http://globalr2p.org/media/pdf/GCR2P_General_Assembly_Debate_Assessment.pdf [2012.02.15.]

${ }_{246}^{245}$ Ibid.

246 A/64/864 http://daccess-dds-ny.un.org/doc/UNDOC/GEN/N10/450/20/PDF/N1045020.pdf ?OpenElement [2012.02.16.]
} 
hiszen számos szerve ${ }^{247}$ rendelkezik a megelőzést elősegítő mechanizmusokkal és a bejövő információk elemzéséhez szükséges szakértői gárdával.

A fő hiányosságok, amelyek akadályozzák, hogy az ENSZ megfelelő módon közbelépjen, amikor szükséges:

a. Az ENSZ szervezetén belül az egyes szervek és a tagországok nem osztják meg egymással a rendelkezésre álló információkat és elemzéseket

b. Az összegyüjtött információt nem a védelem felelősségének szürőjén keresztül elemzik, hanem a szélesebb értelemben vett konfliktusmegelőzés szempontjai alapján

c. Az ENSZ-nek „értékelő eszközökre és kapacitásra” van szüksége az Alapokmány hatodik, hetedik és nyolcadik fejezetével összhangban adott, a védelem felelősségének elve miatti válaszok „,hatékonysága és rendszerszintü koherenciája" érdekében.

A jelentés kiemeli, hogy az ENSZ a regionális és szubregionális szervezetekkel való szorosabb együttmüködéssel, ,kétirányú információáramlással” kiküszöbölheti a fent említett hiányosságokat. A főtitkár hangsúlyozza jelentésében, hogy védelem felelősségéve kapcsolatos ENSZ-döntések megalapozottsága érdekében figyelembe kell venni az egyénektől, civil szervezetektől, ország- vagy régióspecifikus szakértőktől, emberi jogi aktivista szervezetektől, illetve a helyiektől beszerezhető információkat.

Ezt a jelentést is megvitatta az ENSZ Közgyülése. Az interaktív párbeszéd során több mint negyven tagállam képviselői szólaltak fel. ${ }^{248}$ Sok tagállam egyetértett abban, hogy a védelem felelőssége normát növekvő konszenzus övezi a 2005-ös világcsúcson történt „kihirdetése” óta és jelentős előrelépés történt az alkalmazásában is. A főtitkár jelentését figyelembe véve a tagállamok többsége egyetértett abban, hogy az igazi kihívás abban rejlik, hogy a szerzett információkat megfelelően elemezzék, és utána megfelelően használják fel, ha cselekvésre kerül sor. Csak néhány tagállam adott hangot ellenkezésének a védelem felelősségével kapcsolatban. Véleményük szerint az elv csak a katonai intervenciót hivatott alátámasztani bizonyos esetekben, és az elv jellegéből adódóan ellentétes az állami szuverenitással. Ezek a tagállamok kétségeiket

${ }^{247}$ Többek között: Humanitárius Ügyek Koordinációs Hivatala (OCHA), Intézményközi Állandó Bizottság, ENSZ Emberi Jogi Főbiztossága (OHCHR), ENSZ Menekültügyi Főbiztossága (UNHCR)

${ }^{248} \mathrm{http}: / /$ www.responsibilitytoprotect.org/ICRtoP\%20Report\%20of\%20EW\%20dialogue\%20on\%209\%2 0August $\% 202010 \% 20$ FINAL.pdf [2012.02.17.] 
hangoztatták a Biztonsági Tanács válsághelyzetekben tanúsított szelektív döntéshozatalával kapcsolatban, valamint nagyobb szerepet szánnának a Közgyülésnek a tömeges emberi jogi jogsértések problémájának megoldásában. Felmerült, hogy a tagállamok egyéni döntései helyett a különleges megbízottak döntenek a védelem felelőssége elv továbbfejlesztéséről.

2011 júliusában jelent meg az ENSZ-főtitkár legutóbbi, harmadik védelem felelősségével foglalkozó jelentése a regionális és szubregionális szervezetek szerepéröl ${ }^{249}$ (The Role of Regional and Sub-regional arrangements in Implementing the Responsibility to Protect). Ebben a hárompilléres megközelítés segítségével elemezte a védelem felelősségének gyakorlati alkalmazását. Az első pillér kapcsán megjegyezte, hogy a regionális szervezetek számos esetben segíthetnek a kormányoknak a lakosság védelmében: segíthetik a globális standardokhoz való helyi alkalmazkodást, az ún. spillover (túlcsorduló) hatásokra (pl. menekültáradat) adott hatékonyabb válaszadást, mediációs és tényfeltáró bizottságok munkáját, régiók közötti együttmüködést, a regionális igazságszolgáltatást, stb. A második pillér keretében a regionális szervezetek segíthetik a legjobb gyakorlatok (best practices) terjesztését, a jogállamiság erősödését, a regionális katonai és civil kapacitás kiépítését. A harmadik pillér hatékony megvalósulását is elősegíthetik, ha szigorú emberi jogi feltételekhez kötik a tagságot a regionális szervezetekben, igyekeznek megakadályozni a további gyülöletkeltést, együttmüködnek a Nemzetközi Büntetőbírósággal.

Ezt a dokumentumot is megvitatta a Közgyülés plenáris ülése. ${ }^{250}$ A felszólalók többsége utalt rá, hogy a védelem felelőssége ellentmondásos elképzelésből folyamatosan fejlődő normává, 2011-ben pedig „hadműveleti realitássá” vált. A megbeszélés során főként az elefántcsontparti és líbiai események tanulságát igyekeztek megvitatni. Kuba, Pakisztán és Venezuela fenntartották korábbi álláspontjukat, mely szerint a védelem felelőssége imperialista doktrína, és az ENSZ-nek tartózkodnia kellene a gyakorlatba átültetésétől, amíg az elv fejlődik és nem alakult ki a végleges változata.

$249 \quad \mathrm{~A} / 65 / 877$. http://www.un.org/en/ga/president/65/initiatives/Report\%20of\%20the\%20SG\%20to $\%$ 20MS.pdf [2012.02.17.]

${ }_{250}$ S/2011/393. http://www.un.org/en/ga/president/65/initiatives/Report\%20of\%20the\%20SG\%20to\% 20MS.pdf [2012.02.17.] 


\subsection{A védelem felelösségének gyakorlati alkalmazása Líbiában}

Míg 2005-től 2010-ig a védelem felelőssége mindössze két határozatban tűnt fel, ${ }^{251} \mathrm{az}$ elv gyakorlati alkalmazása szempontjából igazi áttörés volt 2011, amikor öt alkalommal is a védelem felelősségével kapcsolatos határozatot hozott a Biztonsági Tanács (Líbiával kapcsolatos $1970 .^{252}$ és $1973 .^{253}$ sz. határozat, Elefántcsontparttal kapcsolatos $1975 .^{254}$ sz. határozat, $1996 .^{255}$ határozat Dél-Szudánról, valamint a $2014 .^{256}$ határozatban Jemen kapcsán) konkrét, esetleges beavatkozást igénylő ügyekben.

A nemzetközi jog és diplomácia változásokhoz lassan alkalmazkodó világában ez hatalmas előrelépést jelent. 2011-ben a védelem felelőssége elméleti szintről átlépett a gyakorlati alkalmazás világába.

A 2011-ben elfogadott határozatok közül kulcsfontosságúak a Líbiával kapcsolatosak, amelyek a jelentős nemzetközi érdeklődés és a „kivitelezés” ellentmondásossága miatt a védelem felelőssége elv használatának jövőjére is jelentős hatást gyakorolhatnak.

Mint ismeretes, 2011 februárjában tiltakozássorozat kezdődött Líbiában, amelynek célja Kadhafi 41 éves uralmának megdöntése volt. A Tripoliban kezdődő tüntetések néhány hét alatt továbbterjedtek az ország többi részére, az ellenzéki erök központja Bengázi lett.

A védelem felelőssége azért merült fel Líbiával kapcsolatban, mert a Kadhafirezsim a békés, de szünni nem akaró civil tiltakozó tüntetésekre agresszióval, valószínüsíthetően háborús és emberiesség elleni büncselekmények elkövetésével válaszolt. Kadhafi nyíltan felszólította követőit, hogy támadják meg az ellene tüntetőket, akiket „,patkánynak” és „csótánynak”,257 nevezett, valamint azt kérte, hogy „Líbiát házról házra tisztítsák meg”. Kadhafi azt is bejelentette Bengázi (a tiltakozások egyik központja) lakosainak, hogy a kormányerők nem fognak „könyörületet” mutatni a felkelőkkel szemben. Március 17-én bejelentette, hogy egyesével átfésülnek minden

\footnotetext{
251 A 2006-ban elfogadott 1674. BT-határozat, valamint a 2009-ben elfogadott 63/308. közgyülési határozat

${ }^{252}$ http://www.un.org/News/Press/docs/2011/sc10187.doc.htm, [2012.02.15.]

${ }^{253} \mathrm{http}: / /$ www.un.org/News/Press/docs/2011/sc10200.doc.htm, [2012.02.15.]

${ }^{254} \mathrm{http}: / / \mathrm{www}$. un.org/News/Press/docs/2011/sc10215.doc.htm, [2012.02.15.]

255 http://daccess-dds-ny.un.org/doc/UNDOC/GEN/N11/405/83/PDF/N1140583.pdf?OpenElement [2012.02.19.] [2012.02.19.] http://daccess-dds-ny.un.org/doc/UNDOC/GEN/N11/559/61/PDF/N1155961.pdf?OpenElement

${ }^{257} \mathrm{http} / / / \mathrm{www} . b b c . c o . u k / n e w s /$ world-middle-east-12544624 [2012.02.20.]
} 
házat, ${ }^{258}$ amelyet a nemzetközi közösség úgy értékelt, hogy a város vérfürdőnek néz elébe.

A tömeges atrocitások tovább folytatódtak, válogatás nélkül sújtva a civil lakosságot és az ellenzéki erőket: a jelentések szerint a kormányhü erők kazettás lőszerekkel lakott területeket támadtak. A Nemzetközi Büntetőbíróság helyszínen gyüjtött bizonyítékai alapján „civileket támadtak meg otthonukban, a demonstrációk elnyomására éles lőszereket használtak, a temetési menetek résztvevői ellen nehézfegyverzetet vetettek be, és orvlövészeket helyeztek a mecsetek kijáratához, hogy megöljék az imádkozás után távozókat."259

Nem csak a kormányerök, hanem az ellenzék is követett el tömeges emberi jogi jogsértéseket, többek között a Kadhafihoz hünek vélt lakosok és zsoldosok elleni önkényes letartóztatásokkal és kínzással.

A nemzetközi közösség meglepően gyorsan reagált a helyzetre: eleinte a civil és regionális szervezetek fejezték ki tiltakozásukat (utazási tilalom, embargó, stb.), és hívták fel a kormány figyelmét arra, hogy ne feledkezzen meg a védelem felelősségéről. Az ENSZ népirtásellenes és védelem felelősségére koncentráló különleges megbízottai február 22-én kiadtak egy sajtóközleményt, ${ }^{260}$ amelyben emlékeztette a líbiai kormányt a védelem felelősségére és az erőszak azonnali beszüntetésére szólított fel. Az ENSZ Biztonsági Tanácsa február 26-án egyhangúlag elfogadta az 1970. sz. határozatot, amelyben fegyverembargót vezetett be Líbia ellen, utazási tilalom alá vette a Kadhaficsaládot, és a Nemzetközi Büntetőbíróság elé utalta az ügyet, hogy nyomozást folytasson az esetleges emberiesség elleni büncselekmények ügyében. Az ENSZ Közgyülése március elsején felfüggesztette Líbia tagságát az Emberi Jogi Tanácsban. Mivel ezek a nem-katonai jellegü intézkedések nem hozták meg a várt eredményt, a Biztonsági Tanács március 17-én újabb határozatot fogadott el Kína, Oroszország, India, Brazília és Németország tartózkodásával: a civil lakosság védelme érdekében repüléstilalmi övezetet állított fel Líbia felett és engedélyezte a tagállamok számára, hogy a Biztonsági Tanáccsal együttműködésben „minden szükséges intézkedést hajtsanak végre $[\ldots]$ a civilek és a fenyegetett lakott területek védelmében $[\ldots]{ }^{2}{ }^{261}$ BAN KI-MOON közvetlenül a döntés után ki is adott egy közleményt, amelyben történelmi

\footnotetext{
${ }^{258} \mathrm{http} / / /$ responsibilitytoprotect.org/updated\%20FAQ\%20on\%20Libya(1).pdf [2012.02.20.]

${ }^{259}$ ICC-CPI-20110516-PR667. ICC sajtóközlemény, 2011.május 16.

${ }^{260} \mathrm{http} / / /$ www.un.org/en/preventgenocide/adviser/pdf/OSAPG,\%20Special\%20Advisers $\% 20$ Statement $\% 2$ 0on\%20Libya,\%2022\%20February\%202011.pdf [2012.02.20.]

${ }^{261} \mathrm{http}: / / w w w . u n . o r g / N e w s / P r e s s / d o c s / 2011 / \mathrm{sc} 10200 . d o c . h t m,[2012.02 .20$.
} 
jelentőségünek nevezte ${ }^{262}$ az 1973.sz. határozatot, amely „világosan és egyértelmüen megerösíti a nemzetközi közösség azon szándékát, hogy teljesítse felelősségét, és megvédje a civil lakosságot [...]”, akár saját kormányával szemben is.

A rendelet hatására tizenöt NATO-tagország, valamint Katar, Svédország és az Egyesült Arab Emirátusok összefogott ${ }^{263}$ a repüléstilalmi övezet megvalósítása érdekében. Azonban a beavatkozás túllépett a légtérzár fenntartásán, és a Bengáziban, Miszrátában, Tripoliban, valamint Szirtében a Kadhafi-ellenes erők támogatásával aktívan segítette a felkelőket, és Kadhafi leváltását. Miután október végén megölték Kadhafit $^{264}$ és a felkelők gyakorlatilag az egész országban átvették az uralmat, az Átmeneti Kormány hivatalnokai bejelentették, hogy a polgárháborúnak vége. Az ENSZhatározat kapcsán indult katonai akció hivatalosan október 31-én ért véget, miután az ENSZ Biztonsági Tanácsa egyhangúan megszavazta a repüléstilalom végét. ${ }^{265}$

A katonai akciót számos tagállam és a civil társadalom is kritizálta, mivel sokak szerint a felkelők segítésével a koalíció túllépett eredeti hatáskörén, azaz a civil lakosság védelmén. Az Európai Unió már március 11-én felszólította Kadhafit a lemondásra ${ }^{266}$, ezek után sokak szemében a beavatkozás kevéssé titkolt céljának Kadhafi elmozdítása tünt. Lehet úgy érvelni, hogy ha egy vezető tömeges atrocitásokat követ el a saját népe ellen, akkor az egyetlen hatékony módja a civilek védelmének a vezető elmozdítása. Azonban a katonai akcióban részt vállaló országok ezt soha nem vállalták fel nyíltan, sőt, a semlegességüket hangoztatták.

Az 1973. sz. határozat gyakorlati megvalósítása tehát számos ponton kevéssé egyértelmű. A líbiai esetig soha nem fordult elő, hogy a védelem felelősségének legellentmondásosabb aspektusát- az erőszak alkalmazását mint utolsó lehetőséget- ki kellett volna használni. Sok ország szemében pedig a NATO megbukott az első vizsgán. „Líbia a védelem felelősségét rosszul csengő normává tette”267- nyilatkozta Hardreep Singh Puri, India amerikai nagykövete. Dél-afrikai diplomaták, akiknek országa-

\footnotetext{
${ }^{262}$ http://www.un.org/News/Press/docs/2011/sgsm13454.doc.htm, [2012.02.20.]

${ }^{263} \mathrm{http} / / / \mathrm{www} . b b c . c o . u k /$ news/world-africa-13092451, [2012.02.20.]

${ }^{264} \mathrm{http}: / / \mathrm{www}$. bbc.co.uk/news/world-africa-15390980, [2012.02.20.]

${ }^{265} \mathrm{http}: / / w w w . a l j a z e e r a . c o m / n e w s / a m e r i c a s / 2011 / 10 / 20111027142458981751 . h t m l, ~[2012.02 .20$.

266 Remarks by President Herman van Rompuy at the press conference following the extraordinary European Council on EU Southern Neighbourhood and Libya. http://www.consilium.europa.eu /uedocs/cms_data/docs/pressdata/en/ec/119779.pdf [2012.02.21.], valamint www.euronews.net: 27 leaders, one voice - EU says Gaddafi out now. http://www.euronews.net/2011/03/11/27-leaders-onevoice-eu-says-gaddafi-out-now/ [2012.02.21.]

${ }^{267}$ Homans, Charles [2011]: Responsibility to Protect: A Short History. Foreign Policy, November 2011, http://www.foreignpolicy.com/articles/2011/10/11/responsibility_to_protect_a_short_history?page=0,3 [2012.02.21.]
} 
Indiával ellentétben- támogatta az 1973. sz. határozatot, hasonló aggályaikat fejezték ki: fel vannak háborodva, és úgy érzik, kihasználták őket, mivel a nyugati országok nem vették figyelembe az Afrikai Unió többszöri felhívását a tüzszünetre. ${ }^{268}$ Az Afrikai Unió Közgyülése „mélységes aggodalmát fejezte ki, hogy ezen határozatok egyoldalú értelmezése [1970, 1973. sz. BT-határozatok] annak érdekében, hogy jogi alapot teremtsenek a terepen zajló katonai és egyéb akcióknak, amelyek egyértelmüen túllépnek az ezen határozatokban említett hatókörön veszélyes precedenst teremt." A Közgyülés azt is hangsúlyozta, hogy mindez „negatív hatással lehet a jogbiztonságra épülő nemzetközi rendszer kialakítására tett erőfeszítésekre."269 Velük ellentétben Roger Cohen újságíró például a New York Times hasábjain éppen azt fejtegette 2011 augusztusában, hogy a líbiai intervenció sikeres volt, és ,,a gondolat, hogy a Nyugatnak időről időre meg kell küzdenie értékeiért a barbarizmus ellen a legnagyobb reményünk, hogy a 21. század kevésbé kegyetlen lesz, mint a huszadik század volt."270

A védelem felelősségének támogatói azzal érvelnek, hogy a líbiai beavatkozás sikeresen megelőzte a vérengzést, ellenzői a beavatkozás segítségével kikényszerített rezsimváltásról beszélnek.

Egy dolog biztos: ha a hangsúly eltolódik a civil lakosság védelméről, az az elv további használatát negatívan befolyásolhatja. Edward Luck különleges megbízott kiemelte, hogy a védelem felelősségének lényege nem a rezsimváltás, hanem a rezsim viselkedésének megváltoztatása ${ }^{271}$, azaz elsődlegesen megelőző doktrína.

\footnotetext{
268 Bolotion, Philippe [2011]: After Libya, the question: To protect or depose? August 25, 2011, http://articles.latimes.com/2011/aug/25/opinion/la-oe-bolopion-libya-responsibility-t20110825 [2012.02.21.]

269 "The Assembly expressed deep concern at the dangerous precedence being set by one - sided interpretations of these resolutions, in an attempt to provide a legal authority for military and other actions on the ground that are clearly outside the scope of these resolutions, and at the resulting negative impact on the efforts aimed at building an international order based on legality." In: Extraordinary session of the assembly of the union on the state of peace and security in africa, decision on the peaceful

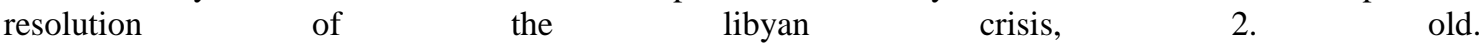
http://www.nepad.org/system/files/D\%C3\%A9cision\%20sur\%20la\%20situaton \%20en\%20Libye\%20_Eng\%20_.pdf, [2012.02.21.]

${ }^{270}$ Cohen, Roger [2011]: Score One for Interventionism. The New York Times, August 29, 2011. http://www.nytimes.com/2011/08/30/opinion/30ihtedcohen30.html?_r=1\&scp=1\&sq=\%22be+prepared+t o+ fight+for+its+values+against+barbarism $\% 22 \&$ st=nyt [2012.02.21.]

${ }^{271}$ The Brookings Institution: International responsibility after Libya, Washington, D.C. January 9, 2012 , Panelists: Edward Luck, Special Advisor on the Responsibility to Protect UN, Jared Genser, Managing Director Perseus Strategies, LLC, Richard Williamson, Senior Fellow, The Brookings Institution, http://www.brookings.edu/ /media/Files/events/2012/0109_libya/20120109_international_libya.pdf, 29. oldal [2012.02.21.]
} 


\subsection{Szíria: a védelem felelösségének kudarca?}

A líbiai beavatkozás sikerét és jogosságát megkérdőjelezők tábora tovább erősödött, amikor nyilvánvalóvá vált, hogy Szíriában is hasonló kaliberü események zajlanak, és „elkelne” a nemzetközi segítség.

Szíriában 2011. március közepén kezdődtek a fennálló rezsim elleni zavargások és az ENSZ becslései szerint jelenleg már 5400 feletti a halálos áldozatok száma. (2012. januári adat) ${ }^{272}$ Habár a halálos áldozatok száma azóta is folyamatosan nő, az ENSZ 2012 januárjától befejezte a becslések nyilvánossá tételét, mivel a hírek valóságalapjáról egyre nehezebb megbizonyosodni. ${ }^{273}$ A hatalmon lévő Aszad elnök tagadja, hogy köze lenne a tüntetők elleni folytatódó erőszakhoz. Az ENSZ különböző szervei és civil szervezetek egybehangzó jelentései alapján a civil lakosság elleni önkényes letartóztatásoknak, kínzásoknak, nehézfegyverzet bevetésének, a sebesülteken segíteni próbáló orvosi személyzet meggyilkolásának vagy munkájának ellehetetlenítése eredményeképpen már Szíria több városában is olyan helyzet alakult ki, amely kimeríti az emberiesség elleni bűncselekmények fogalmát. ${ }^{274} \mathrm{~A}$ válogatás nélküli retorzió mértékét mutatja, hogy a halálos áldozatok között mintegy 300 gyermek is van. ${ }^{275} \mathrm{Az}$ atrocitások súlyosságára és szisztematikus jellegére utal az is, hogy Aszad megtiltotta a belépést a humanitárius és emberi jogi szervezetek képviselőinek. ${ }^{276}$

A szíriai konfliktus egyik legaggasztóbb következménye a Szíria határai mentén kialakuló menekültválság. Jelenleg több mint 800.000 menekültet tart számon az ENSZ Menekültügyi Főbiztossága, akiknek nagy része Jordániában, Libanonban és Törökországban él menekülttáborokban. ${ }^{277}$ Mivel a menekültek között számos kormány ellen harcoló is van, a menekülttáborokat már többször is tüzelték a szíriai kormányerők

\footnotetext{
272 Mohyeldin, Alman [2012]: Russia, China veto UN rebuke of Syrian president, Worldnews on msnbc.com, February 4, 2012, http://worldnews.msnbc.msn.com/_news/2012/02/04/10317567-russiachina-veto-un-rebuke-of-syrian-president, [2012.02.22.]

${ }^{273}$ Syria: Homs under 'heaviest' shelling yet http://www.bbc.co.uk/news/mobile/world-middle-east-16941399, [2013.01.20.]

${ }^{274} \mathrm{http} / / /$ www.ohchr.org/Documents/countries/SY/Syria_Report_2011-08-17.pdf, [2012.02.22.]

275 Bakri, Nada [2011]: As Syria Urges Local Voting, U.N. Puts Toll From Clashes Past 5,000, 12 December, 2011, http://www.nytimes.com/2011/12/13/world/middleeast/clashes-reported-even-as-syriaurges-local-voting.html?_r=1, [2012.02.22.]

${ }^{276}$ Human Rights Council opens Special Session on Human Rights in Syrian Arab Republic, 2 December 2011, http://www.ohchr.org/ch/NewsEvents/Pages/DisplayNews.aspx?NewsID=11679, [2012.02.21.]

${ }^{277}$ UNHCR, Syria Regional Refugee Response, http://data.unhcr.org/syrianrefugees/regional.php, [2013.01.20.]
} 
(pl. a török Kilis tábort 2012. április 9-én). Félö, hogy a szíriai konfliktus regionalizálódik. ${ }^{278}$

A szünni nem akaró erőszak hatására az Arab Liga november 12-én felfüggesztette ${ }^{279}$ Szíria tagságát a szervezetben, és ugyanebben a hónapban gazdasági szankciókat ${ }^{280}$ vezetett be Szíria ellen. Az Európai Unió idővel egyre bővülő gazdasági szankciókat vezetett be (2011 szeptemberében már olajembargót a szíriai olajra), valamint az erőszakért valószínüsíthetően felelős szíriai vezetőkkel szemben utazási tilalmat és a vagyoni eszközök befagyasztását rendelte el. ${ }^{281}$ Az Öböl Menti Együttmüködési Tanács ( Bahrein, Katar, Kuwait, Omán, Szaúd-Arábia és az Egyesült Arab Emirátusok) 2012 februárjában nyilatkozatban jelentette be, hogy visszahívja diplomáciai képviselőit és kiutasítja a szíriai nagyköveteket az öböl menti országokból, mivel mélyen elítéli a „fegyvertelen szíriai nép elleni tömegmészárlást” és felszólította az arab országok vezetőit, hogy „hozzanak határozott intézkedéseket a szíriai nép elleni erőszak fokozódása miatt"” ${ }^{282}$

Az Egyesült Nemzetek Szervezetének álláspontja elméleti síkon ugyan egyértelmű, a gyakorlatban azonban nem sikerült egyetértésre jutni a Szíriában zajló erőszakhullám megfékezésére tett intézkedéseket illetően.

A két különleges megbízott, Francis Deng és Edward Luck 2011. június 2-án emlékeztette a szíriai kormányt, hogy elsődlegesen az ő felelőssége megvédeni a szíriai lakosságot, valamint független, alapos és objektív kivizsgálás megindítását szorgalmazta a nemzetközi emberi jogi normák állítólagos tömeges megsértéséért. ${ }^{283}$ Július $21-$ én $^{284}$ a különleges megbízottak megismételték, hogy a békés tüntetők és a

\footnotetext{
${ }^{278}$ Gazdik Gyula [2012]: Szíria az ,arab tavasz” sodrában, NKE STRATÉGIAI VÉDELMI KUTATÓKÖZPONT, ELEMZÉSEK - 2012/7

${ }^{279}$ Saleh, Yasmine; Samir, Ayman [2011]: Arab League suspends Syria as global pressure rises. 12 November, 2011, http://www.reuters.com/article/2011/11/12/us-arabs-syria-idUSTRE7AB0CP20111112 [2012.02.21.]

280 Syria unrest: Arab League adopts sanctions in Cairo, 27 November, 2011 http://www.bbc.co.uk/news/world-middle-east-15901360, [2012.02.21.]

${ }_{281}$ Újabb szankciók Szíriával szemben, 2011. szeptember 23. http://www.consilium.europa.eu/homepage/showfocus?lang=hu\&focusID=77102, [2012.02.21.]

${ }^{282}$ Gulf Cooperation Council countries to expel Syrian envoys, 7 February, 2012, http://www.france24.com/en/20120207-gulf-cooperation-council-countries-expel-syrian-ambassadorskuwait-bahrain-saudi-emirates-oman-qatar, [2012.02.22.]

${ }^{283}$ United Nations Press Release: Special Advisers of the United Nations Secretary-General on the Prevention of Genocide, Francis Deng, and on the Responsibility to Protect, Edward Luck, on the situation in Syria, 2 June, 2011. http://www.un.org/en/preventgenocide/adviser/pdf/OSAPG \%20statement\%20Syria\%202\%20June\%2020 11\%20FINAL\%20ENGLISH.pdf, [2012.02.22]

${ }^{284}$ United Nations Press Release: Special Advisers of the United Nations Secretary-General on the Prevention of Genocide, Francis Deng, and on the Responsibility to Protect, Edward Luck, on the situation in Syria, 21 July, 2011. http://www.un.org/en/preventgenocide /adviser/pdf/OSAPG\%20statement\%20Syria\%2022\%20July\%2020 11\%20FINAL.pdf, [2012.02.22.]
} 
civil lakosság elleni szisztematikus és széles körben elkövetett erőszakos cselekmények kapcsán gyüjtött bizonyítékok arra utalnak, hogy emberiesség elleni büncselekményeket követtek, illetve követnek el. A különleges megbízottak harmadik sajtóközleményüket 2012. február 10-én adták $\mathrm{ki}^{285}$, ebben felhívták a figyelmet, hogy a különböző vallási és etnikai csoportok közötti feszültség egyre nő az országban, amelyet a csoportok közötti bizalomépítő intézkedések segítségével kellene orvosolni. A megbízottak véleménye szerint a Biztonsági Tanácson belüli véleménykülönbségek nem tántoríthatják el a nemzetközi és regionális szervezeteket, a civil társadalmat attól, hogy igyekezzen megelőzni az erőszak folytatódását.

2012. február 23-án Kofi Annant, a világszervezet korábbi főtitkárát nevezték ki az ENSZ és az Arab Liga szíriai válsággal foglalkozó közös különmegbízottjává. Annan március 16-án ismertette hatpontos tervét az ENSZ BT tagjaival, amelynek lényege, hogy a harcoló felek vállalják, hogy 2012.április 10-től a harcokat beszüntetik, tartós fegyverszünet kezdődik. Az Annan-terv megvalósítása a politikai átalakulási folyamat kibontakozását is lehetővé tette volna. Április 12-én átmeneti tüzszünet állt be, azonban ez május végén összeomlott. Kofi Annan augusztusban lemondott, és helyére Lakhdar Brahimit választották meg. A konfliktus a dolgozat lezárásakor, 2012 februárjában már huszonnegyedik hónapja tart, és 2012 decemberében az ENSZ becslése szerint már négymillió ember szorult humanitárius segítségre Szíria területén belül. ${ }^{286}$

A konfliktus eszaklálódása és elhúzódása ellenére a Biztonsági Tanács nem tudott konszenzusra jutni a gyakorlati teendőket illetően. Először 2011. október 4-én, majd 2012. február 4-én is megpróbált elfogadni egy határozatot Szíriával kapcsolatban, de a kísérlet mindkét alkalommal megbukott Kína és Oroszország elutasító szavazatán. ${ }^{287} \mathrm{Az}$ első alkalommal Brazília, India, Libanon és Dél-Afrika tartózkodott, másodszor azonban 13 BT-tagállam egyhangúlag támogatta a javaslatot, Kína és Oroszország azonban ismét élt vétójogával. ${ }^{288}$

\footnotetext{
${ }^{285}$ United Nations Press Release: Special Advisers of the United Nations Secretary-General on the Prevention of Genocide, Francis Deng, and on the Responsibility to Protect, Edward Luck, on the situation in Syria, 10 February, 2012. http://www.un.org/en/preventgenocide /adviser/pdf/Statement\%20on\%20Syria\%2010\%20 Feb\%202012\%20-\%20ENGLISH.pdf, [2012.02.22.]

${ }^{286}$ Syria: UN-Arab League envoy warns of limited options, dangers of fragmentation http://www.un.org/apps/news/story.asp?NewsID=43856\#.UR4j3qVrgaA, [2013.02.01.]

${ }_{287}$ Moszkva a Nyugatot okolja a szíriai határozat vétójáért, http://www.origo.hu/nagyvilag/20120205sziria-veto-az-ensz-btben-az-ellenzek-szerint-oroszorszag-es.html, [2012.02.23.]

${ }^{288}$ Security Council fails to adopt draft resolution condemning Syria's crackdown on anti-government protestors, owing to veto by Russian Federation, China, 4 October 2011, http://www.un.org/News/Press/docs/2011/sc10403.doc.htm, [2012.02.23.]
} 
Az első határozattervezet elítélte a súlyos és szisztematikus emberi jogi jogsértéseket és figyelmeztette a szíriai kormányt, hogy a helyzet súlyosbodása esetén szankciók várhatóak. A Líbiával kapcsolatos 1973. sz. határozat szövegében foglaltak kiterjesztő értelmezése sokkal óvatosabbá tette a Biztonsági Tanácsban ülőket, és valószínűleg ennek tudható be, hogy a katonai beavatkozást nem is említő határozatot sem sikerült elfogadtatni. ${ }^{289}$

A második határozattervezetet az Arab Liga dolgozta ki, és az erőszakos cselekmények azonnali beszüntetését, a fogva tartottak szabadon bocsátását, a fegyveres erők civil területekről való kivonását és szabad bejárást kért az ENSZ, nemzetközi civil és emberi jogi szervezetek megfigyelőinek. Ez a tervezet is megbukott, mert Oroszország ragaszkodott hozzá, hogy a kormányellenes tüntetők felelősségét is említse meg a határozat szövege. Az Oroszország által javasolt változtatásokat számos BT-tag nem fogadta el, így nem sikerült megegyezésre jutni a végső szavazás előtt.

Oroszország vétójának magyarázata többek között, hogy Szíria Oroszország fontos szövetségese és fegyverexportjának felvevőpiaca. Mindemellett az egyik szír kikötő, Tartusz az egyetlen orosz földközi-tengeri hadihajóbázis, így gyakorlatilag Szíria maradt az egyetlen kapcsolat Oroszország és az arab világ között. ${ }^{290}$

A híradásokban Kína vétóját általában úgy kommentálják, hogy Peking Moszkvához igazodik a szavazáskor. Li Baodong kínai ENSZ-nagykövet úgy nyilatkozott, hogy egy kikényszerített rezsimváltás sértené az ENSZ Alapokmányát és a nemzetközi kapcsolatok általános elveit. ${ }^{291}$ Kína ellenkezésének hátterében valószínüleg a „nemzeti szabadságmozgalmakkal” kapcsolatos hagyományos óvatosság áll, hiszen Kína nem szeretne nemzetközi precedenst teremteni a beavatkozásra. A tibetiek és ujgurok, valamint más, a kínai vezetés politikáját ellenző csoportok tiltakozó mozgalmait már többször leverték. Kína dinamikusan növekvő gazdasága és társadalma éles ellentétben áll a merev uralkodó rezsimmel, tehát várhatóak további belső problémák. Ezek fényében Kína ellenzi a beavatkozást. Egyes szakértők szerint Kína

\footnotetext{
289 Security Council fails to adopt draft resolution on Syria as Russian Federation, China veto text supporting Arab League's proposed peace plan, 4 February, 2012, http://www.un.org/News/Press /docs/2012/sc10536.doc.htm, [2012.02.23]

${ }^{290}$ Grove, Thomas; Solomon, Erika: Russia boosts arms sales to Syria despite world pressure, 21 2012 , http://www.reuters.com/article/2012/02/21/us-syria-russia-armsidUSTRE81K13420120221, [2012.02.23.]

${ }_{291}$ China: No forced 'regime change' in Syria, 1 February, 2012, http://www.china.org.cn/world/201202/01/content_24519621.htm, [2012.02.23.]
} 
azért is támogatja Oroszországot, mert reméli, hogy Észak-Korea kapcsán Oroszország viszonozza majd a segítséget, ha szükség lesz rá. ${ }^{292}$

Oroszország és Kína is a szuverenitás szük értelmezésének pártfogói, azaz az állam területén zajló események szerintük nagyrészt belügynek számítanak. Nem fogadják el, hogy emberi jogi aggályokkal igazolható a beavatkozás, amelynek szerintük igazi célja a rezsimváltás. Az ilyen jellegű intervenció megjósolhatatlan következményekkel jár és aláássa a nemzetközi rendszer kiszámíthatóságát. Másrészt úgy vélik, hogy a nyugati országok emberi jogi mércéje kettős: míg az ellenséges országok emberi jogi jogsértéseit nem tolerálják, addig a baráti országok és szövetségesek szabályszegései fölött szemet hunynak. ${ }^{293}$

Moszkva és Peking azzal vádolja a Líbiában beavatkozó koalíció tagjait, hogy visszaélt az Oroszország és Kína tartózkodásával elfogadott BT-határozat szövegével, és a civil lakosság védelmének leple alatt elősegítette Kadhafi leváltását. Ráadásul az egész folyamat nem megnyugtató módon zárult, hanem zürzavarhoz vezetett Líbiában. Ezt az ellentmondásos akciót Moszkva és Peking nem hajlandó megismételni Szíria esetében.

Ez a helyzet kísértetiesen emlékeztet arra, amikor az Amerikai Egyesült Államok többek között azért nem támogatta a beavatkozást 1994-ben Ruandában, mert 1993-ban volt egy ellentmondásos katonai akciója Szomáliában, amelynek során 18 amerikai katonai életét vesztette. ${ }^{294}$ Jelenleg a szíriai emberek fizetik meg az árát annak, hogy számos ország szerint a NATO túllépte az 1973. sz határozat szerinti felhatalmazását Líbiában. A líbiai beavatkozás ellentmondásos megítélése tehát rendkívül negatívan hat a védelem felelősségének alkalmazására Szíriában.

Sokak szemében az elv a líbiai beavatkozás óta egyet jelent a katonai beavatkozással. Ez azonban a védelem felelősségének definíciójából nem következik. A lakosság védelme a népirtástól, háborús és emberiesség elleni büncselekményektől és etnikai tisztogatástól elsődlegesen az adott ország vezetésének felelőssége. Ha ennek a felelősségének a vezetés nem tud vagy nem hajlandó eleget tenni, akkor a nemzetközi közösség teljes diplomáciai arzenálját bevetheti az elítélő és figyelmeztető

\footnotetext{
${ }^{292}$ Charbonneau, Louis [2012]: Russia U.N. veto on Syria aimed at crushing West's crusade, 8 February, 2012, http://www.reuters.com/article/2012/02/08/us-un-russia-idUSTRE8170BK20120208, [2012.02.23.] 293 Menon, Rajan [2012]: The Russia-China Veto: What Next for Syria?, 6 February, 2012, http://www.huffingtonpost.com/rajan-menon/syria-veto-united-nations_b_1256322.html, [2012.02.23.] ${ }^{294}$ Clarke, Walter; Herbst, Jeffrey [1996]: Somalia and the future of humanitarian intervention,Foreign Affairs, New York, Mar/Apr 1996, http://www.mtholyoke.edu/ jwestern/ir317/clark.htm, [2012.02.22.]
} 
nyilatkozatoktól a gazdasági kényszerítő intézkedéseken keresztül az egyeztető tárgyalásokig. A katonai beavatkozás a skála legvégén helyezkedik el.

Ha az Egyesült Nemzetek Szervezete valóban foganatosítani akarná a védelem felelősségét, akkor már elfogadhatott volna legalább egy erőszakot elítélő határozatot, amely fegyverembargót rendel el a térségben, vagy nyomást gyakorolhatott volna a szíriai kormányra gazdasági szankciókkal. Számos nem katonai eszköz áll rendelkezésre, amelyeket a Biztonsági Tanács korántsem aknázott ki.

Ez pedig azt mutatja, hogy a védelem felelősségének ígéretesen induló karrierje megtörni látszik. Ez az elv alkalmas lehetett volna a legsúlyosabb megítélés alá eső büntettek, többek között a népirtás megakadályozására. A nemzetközi közösség politikai akaratának hiánya azonban lehetetlenné teszi egyenletes, részrehajlástól mentes alkalmazását a szükséges helyzetekben.

Az ENSZ Biztonsági Tanácsa Szíria kapcsán immár sokadszorra bizonyította alkalmatlanságát a válsághelyzetek megoldására. Ez az impotencia a Biztonsági Tanács jellegéből fakad, hiszen itt olyan kérdésekről szavaznak az országok, amelyekben kisebb-nagyobb mértékben maguk is érintettek. A különböző hátterü, berendezkedésű országok érdekei mentén alakul a szavazás, a politikai megosztottságnak pedig a civil áldozatok fizetik meg az árát.

A figyelmet talán érdemesebb lenne a Közgyülésre fordítani, amelynek döntései ugyan nemzetközi jogilag nem kötelezőek, de konszenzus sem szükséges az elfogadásukhoz. A Közgyülés már három határozatot is elfogadott Szíriával kapcsolatban, 2011 novemberében és decemberében, valamint 2012 februárjában. Az első határozatban a Közgyűlés emberi jogi bizottságának javaslatára felszólította a szíriai kormányt, hogy vessen véget az emberi jogi jogsértéseknek és fogadja el az Arab Liga béketervét. Ez a határozat 122 támogató, 13 ellenző és 41 tartózkodó szavazattal került elfogadásra. $^{295}$ A második határozat az elsőhöz képest még megfigyelők beengedését is kérte a szíriai vezetéstől. 133 ország szavazott mellette, 11 ellene és 43 ország tartózkodott. ${ }^{296}$ A legutóbbi határozat nagyvonalakban megegyezett a korábban a

295 U.N. assembly rights committee condemns Syria, November 22, 2011. http://www.reuters.com/article/2011/11/22/us-syria-un-idUSTRE7AL1U320111122, [2012.02.23.]

${ }^{296}$ General Assembly urges Syria to implement Arab League plan to end violence, 19 December, 2011, http://www.un.org/apps/news/story.asp?NewsID=40782\&Cr=syria\&Cr1, [2012.02.23.] 
Biztonsági Tanács elé terjesztett határozattervezet szövegével, és ezt a Közgyülésnek 137 igen, 12 nem, valamint 17 tartózkodó szavazattal sikerült elfogadnia. ${ }^{297}$

A szavazati arányok lassú eltolódása azt mutatja, hogy a helyzet súlyosbodása nem hagyja érintetlenül a nemzetközi közösség államait. A konkrét cselekvéshez azonban ennél sokkal nagyobb egyetértésre, és úgy tünik: súlyosabb atrocitásokra lenne szükség. Az ellenzék erői már „népirtási cselekményekről” (genocidal acts) beszélnek. ${ }^{298}$

Vajon hány áldozat kell még ahhoz, hogy a nagyhatalmak egyetértésre jussanak?

Amíg a konszenzus nem születik meg, addig a védelem felelőssége nem más, mint egy szép ígéret, amelynek beteljesítése várat magára.

A genocídium fogalmának, a megelőzés rendszerének, valamint a védelem felelőssége elv alapjainak áttekintése után a következő fejezetben rátérek a hipotézisek alátámasztását szolgáló esettanulmányokra.

${ }^{297}$ General Assembly adopts resolution strongly condemning 'widespread and systematic human rights violations by Syrian authorities, 16 February, 2012, http://www.un.org /News/Press/docs/2012/ga11207.doc.htm [2012.02.23.]

${ }^{298}$ Sterling, Joe; Maktabi, Rima és Fahmy, Mohamed Fadel: Syrian opposition cites regime 'acts of genocide' December 21, 2011, http://articles.cnn.com/2011-12-21/middleeast/world_meast_syriaunrest_1_idlib-syrian-revolution-syrian-national-council?_s=PM:MIDDLEEAST, [2012.02.23.] 
1. ábra Afrika térképe

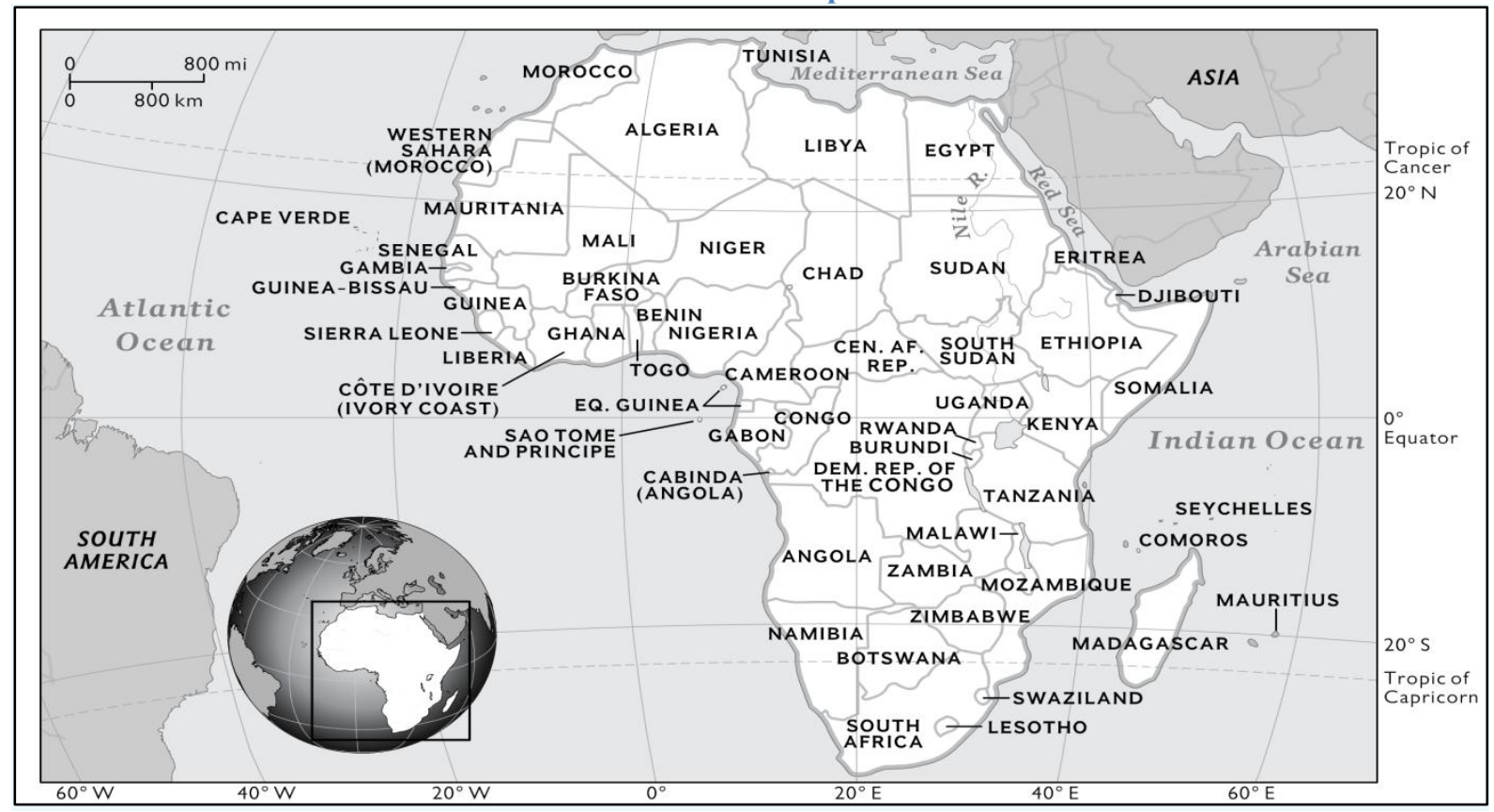

Forrás: National Georgraphic Education (2013): Africa

A disszertációban tárgyalt esettanulmányok helyszíne az afrikai Nagy Tavak régió. Az afrikai Nagy Tavak régió neve a Nagy-hasadékvölgy körül kialakult afrikai tavak rendszeréből származik. ${ }^{299}$

A dolgozatban a Jean- Pierre Chrétien Afrique des Grand Lacs c. könyvében tárgyalt definíciót vesszük alapul, azaz az afrikai Nagy Tavak régió alatt Burundit, a Kongói Demokratikus Köztársaság keleti részét, Ruandát, Nyugat-Tanzániát és Ugandát értjük.

${ }^{299}$ Albert-tó, az Edward-tó, a Kivu-tó, a Malawi-tó, a Tanganyika-tó, a Turkana-tó és a Victoria tó 
2. ábra Az afrikai Nagy Tavak régió

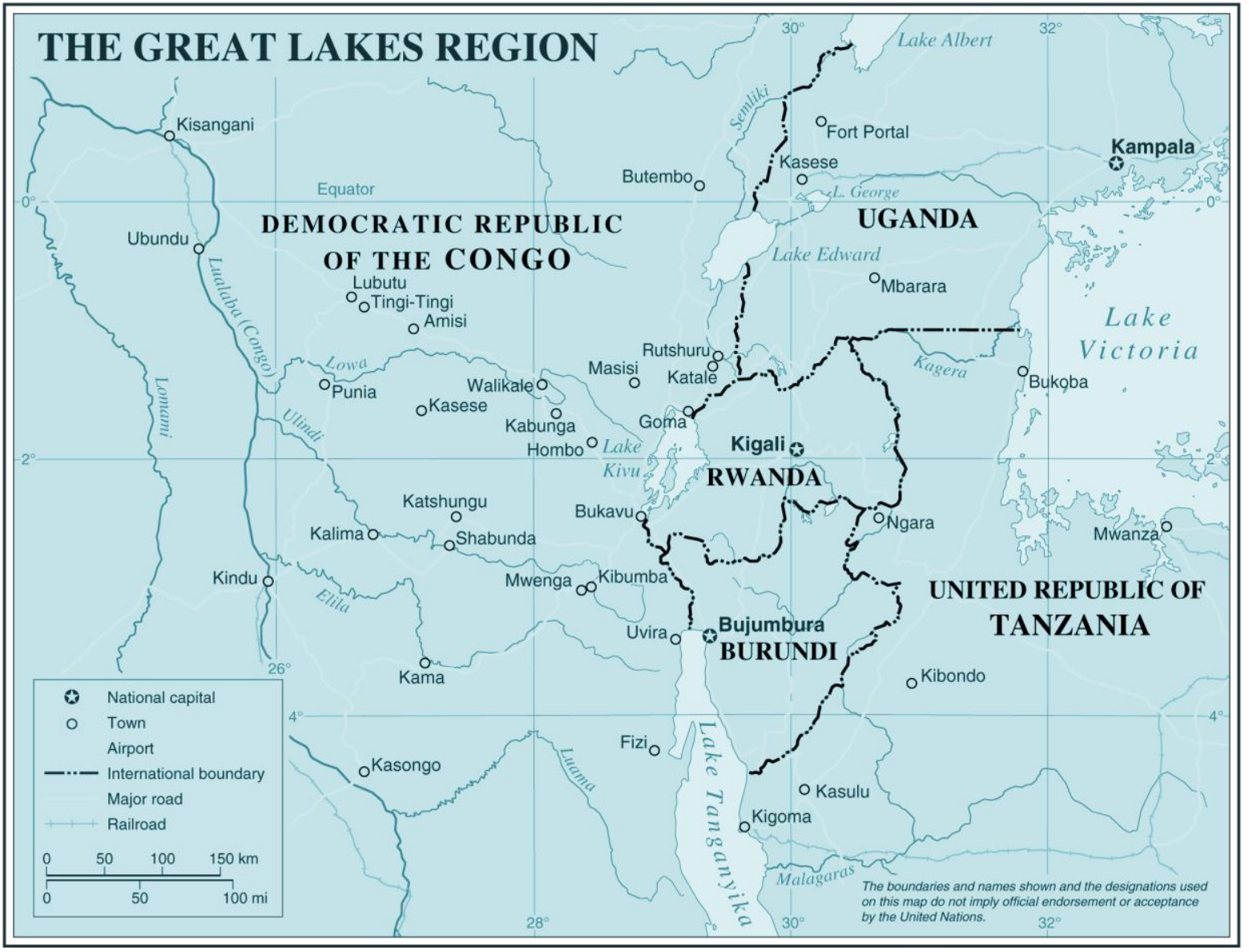

Forrás: United Nations (2004): Map No. 4004.1, UN Department of Peacekeeping Operations, Cartographic Section 


\section{5.fejezet: Népirtás Burundiban - 1972}

„, Mit jelent hutunak vagy tutszinak lenni? Már nem jelenti azt, hogy bantu vagy hamita vagy, szolga vagy úr! Azt jelenti emlékszel ki ölt meg egy hozzád közel állót tizenöt éve vagy elgondolkodsz ki fogja megölni a gyermekedet tíz év múlva... „300

3. ábra Burundi térképe

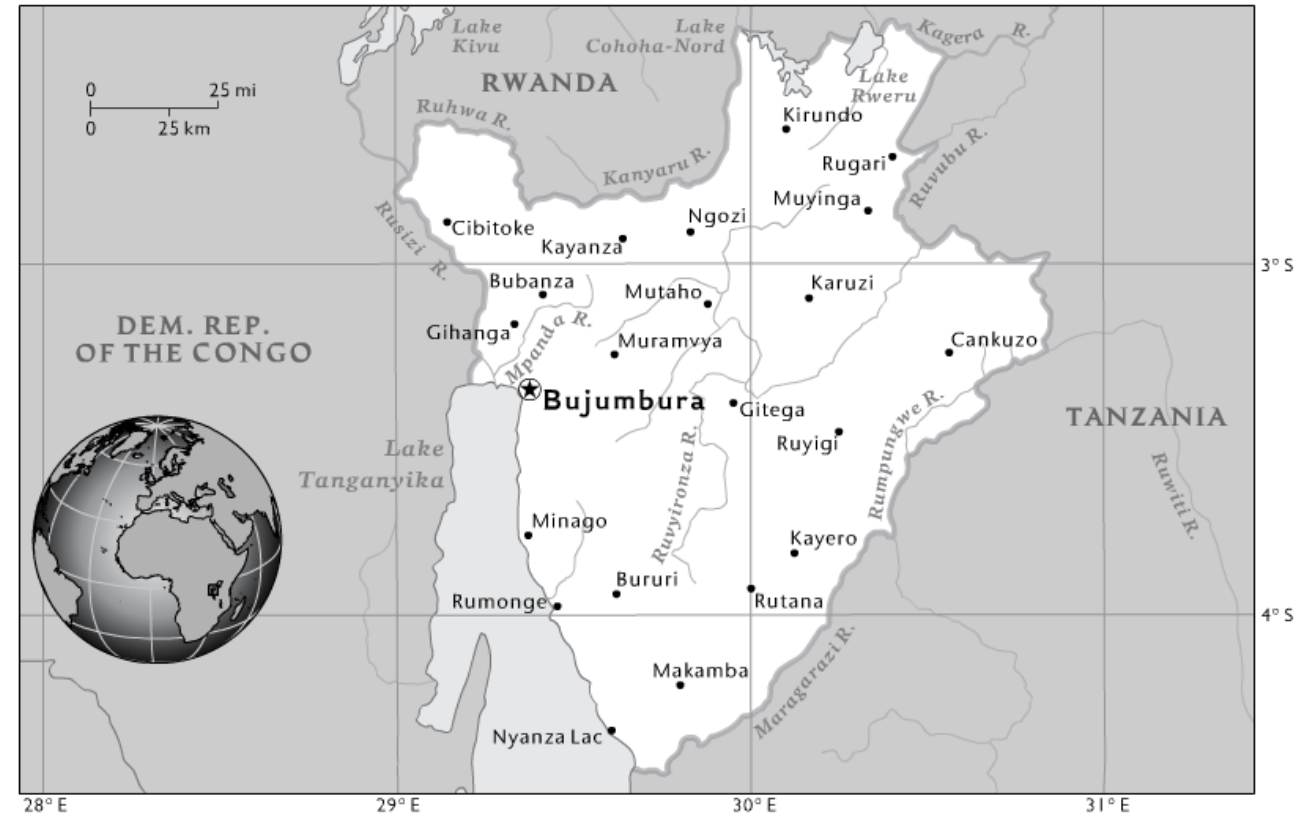

Forrás: National Georgraphic Education (2013): Burundi

Az Afrikai Nagy Tavak régió első népirtása a huszadik században Burundiban történt huszonkét évvel a hatalmas sajtóvisszhangot kapott ruandai népirtás előtt. 1972 májusától júliusáig mintegy 200.000 és 300.000 közötti $^{301}$ hutu vesztette életét a nagyrészt tutszi hadsereg vezette erőszakos cselekményekben, amelyek egy tavaszi hutu felkelés aránytalan leveréséhez kapcsolódtak.

Ezt a népirtást Burundi kormánya még napjainkban sem ismeri el, valamint a Nyugat is hajlamos megfeledkezni róla, de a régió dinamikájának megértése szempontjából kulcsfontosságú a tárgyalása. Ez az erőszakhullám beleégett a hutu kollektív emlékezetbe, és nem csak Burundi, hanem a környező országok hutu menekültjei révén számos szomszédos ország folyamataira hosszú távú hatást gyakorolt.

\footnotetext{
${ }^{300}$ Chrétien, Jean-Pierre, Prunier, Gérard [1988]: Les ethnies ont une histoire Éditions Karthala, Paris ${ }^{301}$ Lemarchand, René [2009]: Chapter Ten: The Burundi Genocide. In: Century of Genocide, 3rd Edition, Taylor and Francis
} 
Az 1972-es események sajtóvisszhangja elenyésző volt. Kevés a hiteles tudósítás, mert csak néhány újságíró tartózkodott ekkoriban Burundiban, és tőlük is megtagadták a belépést az ország bizonyos belső területeire.

A kormány hivatalos álláspontja szerint Burundiban 1972-ben nem történt népirtás. René Lemarchand francia történész, aki már a hetvenes években is foglalkozott Burundival, „kiszámított amnéziának” nevezi a kormány hozzáállását a kérdéshez. Az egyetlen népirtás, amelyet a hivatalos álláspont megemlít, Melchior Ndadaye elnök elleni sikeres merénylethez kapcsolódó erőszakhullám, amikor tutszik több ezer hutut gyilkoltak meg 1993-ban. (Ezt azonban dimenzióiban össze sem lehet hasonlítani az 1972-es erőszakhullámmal). Az 1972-es eseményeket általános hallgatás övezi, de biztosan tudható $^{302}$, hogy az áldozatok túlnyomó része a hutu népcsoporthoz tartozott. Az elkövetők pedig nagyrészt a tutszik közül kerültek ki. A burundi kormány soha nem rendelt el komolyabb nyomozást az ügyben, így napjainkban is rendkívül kevés információ áll rendelkezésre a szervezők személyét, a lebonyolítást, a körülményeket illetően.

A népirtásról szóló források gyakran nem objektívek. Ha a hetvenes években valaki az atrocitásokról szóló beszámolókhoz vagy tanúvallomásokhoz akart jutni, csak a kormány hivatalos forrásaira támaszkodhatott. ${ }^{303} \mathrm{~A}$ történetíráson belül is megfigyelhető egy etnikai törésvonal: a tutszi történészek gyakran úgy vélekednek, hogy a hutu felkelők is népirtó szándékról tettek tanúbizonyságot, jogos haragot kiváltva a hadsereg részéről. A hutu elbeszélők általában azt állítják, hogy a kormányellenes hutu felkelést maga a kormány provokálta ki, hogy utána a régóta tervezett népirtással válaszolhasson rá. ${ }^{304}$

Az erőszakhullám az ország déli részén kitört hutu felkelés miatt robbant ki, amely több ezer tutszi civil áldozatot követelt. A hutu civilek fizikai megsemmisítését az esetek többségében az ország hadserege követte el, karöltve a kormánypárt fiatal aktivistáival. Az atrocitások súlyosságára utal, hogy 1972-ben több tízezer hutu férfi, asszony és gyermek menekült el a környező országokba menedéket keresni.

A népirtás súlyos hosszú távú következményekkel járt Burundira nézve, teljesen átrajzolta az ország etnikai térképét. A tanult hutu elit eltüntetésével tutszi etnokrácia vette kezdetét, amelyet tutszi hadsereg védett. Ruandával ellentétben, Burundiban az

\footnotetext{
${ }^{302}$ Kiraranganiya, Boniface. [1985]. La Vérité sur le Burundi. Sherbrook, Canada: Editions Naaman.

${ }^{303}$ Lemarchand, René [2009]

${ }^{304}$ Nsanze, Augustín [2003]: Le Burundi contemporain: L'état-nation en question, Paris, L'Harmattan
} 
elkövetök viszonylag hosszú időre elérték, amit akartak: a népirtást követő mintegy húsz évben az adminisztráció, a kulcspozíciók a kormányban, a hadsereg és a gazdaság tutszi kezekbe került. Ezzel párhuzamosan azonban a hutu menekültek körében renkívüli tutszi-ellenesség alakult ki, és a népirtás öröksége mai napig érzékelhető nyomot hagyott a hutu kollektív emlékezetben.

\subsection{Történelmi háttér}

A burundi társadalom alkotóelemei: körülbelül 85 százalékban hutuk, mintegy 14 százalékban tutszik, és a társadalom egy százalékát alkotja a twa népesség. Negyedik csoportként tekint magára a kiterjedt királyi család, akik ganwának tartják magukat (bár az Alkotmány nem ismeri el, hogy külön csoportot alkotnának). A különböző etnikai csoportok (maguk a burundi lakosok is így utalnak a hovatartozásukra) eredetét tekintve számos mendemonda kering: a köztudatban egy meglehetősen egyszerü változat vert gyökeret. Ennek lényege, hogy Burundi első lakói a pigmeus twa-k voltak, akik vadászatból tartották fenn magukat, ezután érkeztek a hutuk, akik földműveléssel foglalkoztak, majd végül a valószínüleg hamita eredetű (talán Afrika szarva tájáról érkezö), marhapásztor- és marhatulajdonos tutszik települtek le ezen a területen. Az eredetmítoszokra nincs biológiai, nyelvi vagy archeológiai bizonyíték, de cáfolat sincs. $\mathrm{Az}$ etnikai csoportok földrajzi eloszlása nem egyenletes: az országnak van néhány területe, ahol a tutszik élnek többségben (Mwaro), míg máshol elenyésző kisebbségben fordulnak csak elő (Cibitoke, Bubanza).

A hutuk és tutszik évszázadokig éltek ugyanazokon a területeken, ugyanazt a nyelvet beszélve, ugyanazt az Istent és királyt tisztelve, ha nem is konfliktusok nélkül, de viszonylag stabil társadalmi struktúrában. Az esetleges konfliktusok nem etnikai, hanem klán alapúak voltak (az etnikai hovatartozásnál sokkal nagyobb jelentősége volt a klánnak), és rendezésüket segítette a bashingantahe (idősek tanácsa) intézménye. A társadalmi rétegződés is klánokon alapult. A Muramvyaból, északról származó tutszik (Banyaruguru) ${ }^{305}$ például magasabbrendűnek tartották magukat a délről, Bururiból való tutsziknál (Bahima vagy tutszi-hima). Ez a klánok szerinti tagozódás később éles politikai harcok forrásává vált.

A tutszik tehetősebbek lévén saját tehéncsordáikat legeltették, a szegényebb hutuk vagy a tutsziknak dolgoztak, vagy földet müveltek. Napjainkban azonban ez már nem

${ }^{305}$ A Banyaruguru klánon belül a Bezi és Batare alklánok is szemben álltak egymással. 
ilyen egyértelmü, mert sok hutu előrelépett a társadalmi ranglétrán és marhatulajdonos lett, és ma már számos földmüves tutszival is találkozhatunk. A burundi társadalomban azonban meggyökeresedett az a nézet, hogy a tutszik gazdagabbak és marhatulajdonosok, a hutuk pedig szegényebb földmüvesek. Pedig az etnikai „státusz” sem számított merev kategóriának: ha egy hutunak sok tehene volt, tutszivá léphetett elő, erre még külön szó is van: kwihutura. ${ }^{306}$

A másik leegyszerüsítés, ami széles körben elterjedt, de ma már nem általános: a tutszik és ganwák magasak, bőrszínük világosabb és hosszú orruk van. Ezzel szemben a hutuk alacsonyak, köpcösek, sötét börüek és széles, lapos az orruk. Az évszázadok óta gyakori vegyesházasságok miatt a külső alapján nem lehet biztosan megállapítani, hogy ki melyik népcsoporthoz tartozik. Hogy egy illusztris példát említsünk: Michel Micombero, Burundi elnöke 1966-tól 1976-ig, külseje hutu, ő azonban tutszi. ${ }^{307}$ A burundi társadalom férfiközpontú, így például ha valakinek az édesapja hutu, akkor a gyermek is hutunak minősül, hiába hasonlít jobban tutszi édesanyjára. ${ }^{308}$

Burundi először német, majd belga gyarmat volt. 1962-ben nyerte el függetlenségét. Amikor Burundi függetlenné vált, alkotmányos monarchia volt az államforma, ahol a királyra (mwami) Isten megtestesüléseként tekintettek. A király meglehetősen stabil és összetartó társadalom felett uralkodott, a kormány pedig vegyes ganwa, hutu és tutszi elemekből állt. ${ }^{309}$ A királyi ganwák is igyekeztek minél több támogatót szerezni mindkét etnikai csoportból, így a kialakult érdekcsoportokban általában vegyesen fordultak elő hutuk és tutszik. A függetlenség elnyerése után kerültek először napirendre az etnikai alapú feszültségek politikai téren- ennek oka pedig föként a ruandai forradalom $(1959-61)^{310}$ volt.

A ruandai hutu köztársaság kikiáltása számos ambiciózus burundi hutu politikus merített erōt a szomszédos, számos szempontból hasonló országban lezajlott változásból. Sokuk számára Ruanda egyfajta modellt, jövőképet jelentett. Ezzel szemben a legtöbb tutszi éppen ennek ellenkezőjét érezte: ők mindenáron el akarták kerülni a ruandai köztársasághoz hasonló fordulatot Burundiban. Mindkét fél képzeletét

\footnotetext{
306 Watt, Nigel [2008]: Burundi: Biography of a Small African Country. Columbia University Press, Chapter 3: Kings, Germans, Belgians, Hutus, Tutsis. Twa, 23-33.old.

${ }^{307}$ Burundiban az etnikai alapú erőszak során sokan vesztették életüket azért, mert a halálosztagok az illető külseje alapján téves következtetéseket vontak le az etnikai hovatartozására vonatkozóan.

${ }^{308}$ Watt, Nigel [2008]

${ }^{309}$ Lemarchand, René [1970]: Rwanda and Burundi, London, Pall Mall Press

${ }^{310}$ Ruandában a belga gyarmatosítók és az egyház aktív támogatásával megdöntötték a tutszi kisebbség uralmát, és a többségi hutuk kezébe került a hatalom.
} 
feltüzelték a Ruandából tízezrével érkező tutszi menekültek, akiknek beszámolói élénk képet festettek a hutu forradalom borzalmairól.

A hutu-tutszi feszültségek elmérgesedésében fordulópontot jelentettek az első független választások 1965-ben. A választások során a hutuk elsöprő győzelmet arattak. Azonban a király hutu miniszterelnök kinevezése helyett a királyi származású, a királyi udvar protezsáltjaként elhíresült ganwa Bihumuganit ültette a miniszterelnöki székbe. A hutu elit kisemmizettnek érezte magát, és agresszívan reagált. 1965. október 18-án puccsot indítottak a királyi palota ellen, erre a király elhagyta az országot, és sosem tért vissza. Válaszul a hadsereg és rendőrség tutszi egységei letartóztattak és kivégeztek 86 vezető hutu politikust és katonai tisztviselőt. 1969-ben is volt egy állítólagos hutu összeesküvés, amikor 70 hutut tartóztattak le, és közülük huszonötöt halálra is ítéltek. 311

A fenti esetek hatására a még életben maradt hutu politikusokban egyre erösödött az érzés, hogy az erőszakra csak erőszakkal lehet válaszolni. A hutuk kizárása a kormány és a civil szféra fontosabb pozícióiból, valamint a hadsereg magasabb beosztásaiból egyre nagyobb elégedetlenséget keltett. Különösen kézzelfogható volt ez az elégedetlenség a hutu egyetemisták körében.

Az 1972-es népirtást megelőző időszakban Burundiban eluralkodott a káosz. A különféle tutszi klánok egymásnak estek. A tutszi-hima és tutszi-banyaraguru klánok folyamatosan egymás ellen áskálódtak, a politikai színtér különféle összeesküvésektől volt hangos. A Le Soir c. belga napilap már 1967 szeptemberében írt a növekvő feszültségekről:

„[...] a tutszik elvesztek az intrikákban [...] a hutuk ezért elkezdtek próbálkozni a hatalmi helyzet megváltoztatásával. Bujumbura környékén három tutszi házát is felgyújtották. [...] Hutu minisztereket tartóztattak le, de a hutuk már megint készülnek valamire. [...] Veszélyes, mert a hutuknak nincsenek vezetőik, a tutszik nagyon jelentős befolyással bírnak, és az ő oldalukon áll a hadsereg. De a dolog a levegőben lóg. Készülhetünk egy komolyabb lázadásra, vagy akár általános felkelésre is." ${ }^{12}$

Az intrikák hatására Michel Micombero miniszterelnök, aki szük környezetének nagy részével együtt a Hima klánhoz tartozott, elrendelte jónéhány Banyaruguru politikus letartóztatását és bíróság elé állítását. A hutu felkelés többek között azért kezdődhetett 1972 tavaszán, mert a hutuk saját javukra akarták fordítani a tutszi

\footnotetext{
${ }^{311}$ Lemarchand, René [2009]

${ }^{312}$ Le Soir, 1967. 09. 18.
} 
megosztottságot. Ehelyett a közös ellenség támadásának hírére villámgyorsan összekovácsolódott a tutszi elit.

\subsection{A felkelés}

1972. április 29-én Burundi déli részén Rumonge és Nyanza-Lac városában rendkívül erőszakos, hutu vezette felkelés tört ki. Kiraranganiya 1985-ben publikált „Az igazság Burundiról" című művében hutu egyetemistáknak tulajdonítja a hutu felkelés kirobbantását. ${ }^{313}$ A hozzájuk csatlakozó hutu többség a tutszi politikai megosztottságot vissza nem térő lehetőségnek tartotta a hatalom átvételére.

A szemtanúk szerint a hutuk válogatás nélkül gyilkolták meg a tutszi civileket, de azokat a hutukat is, akik nem voltak hajlandóak csatlakozni hozzájuk. Ezek a megmozdulások mintegy 2-3000 tutszi életét követelték. A felkelök idöközben Vyanda közelében kikiáltották a „République de Martyazo” (Martyazo Köztársaság) megszületését.

A katonaság egy hét múlva beavatkozott és véget vetett a lázadásnak. Utólag nehéz megállapítani, hogy pontosan hányan is lehettek a felkelők. A kormány későbbi állítása szerint mintegy huszonötezren voltak, ez azonban szakértők egybehangzó állítása szerint túlzás. Egy a burundi hadseregnek dolgozó francia helikopterpilóta becslése szerint a felkelők körülbelül ezren lehettek. ${ }^{314}$ René Lemarchand francia szakértő maximum néhány ezerre teszi a felkelők számát.

A kormány válasza aránytalanul brutális volt. Miután május 30-án Michel Micombero miniszterelnök hadiállapotot hirdetett, azonnali katonai segítséget kért a zairei Mobutu elnöktől. Míg a zairei haderő tartotta a frontot a fővárosban, a burundi hadsereg vidékre vonult a „felkelés leverése” érdekében.

Azonban májusra már nem maradt semmilyen felkelés, a kormány hutu civilek tömeges meggyilkolásával akarta megszilárdítani a tutszi hatalmat. A hadjárat augusztusig zajlott megállíthatatlanul. Ekkorra az összes tanult hutu vagy halott volt, vagy elmenekült az országból.

A halottak számát nagyon nehéz ennyi idő távlatából, pontos dokumentáció és beszámolók híján megbecsülni. A kormány eleinte tizenötezer áldozatról beszélt, míg a hutuk 300.000-re teszik ugyanezt a számot. Napjainkban konzervatív becslések szerint

\footnotetext{
${ }^{313}$ Kiraranganiya, Boniface. [1985]

${ }^{314}$ Hoyt, Michael [1972]: U.S. Embassy Cables from Bujumbura to State Department. April 29- August 29, 1972 Available at the Univesity of Florida Library, Gainesville
} 
is 100-150.000 közötti áldozatot említenek. Kiraranganiya, aki tutszi, könyvében azt állítja, hogy a 3,5 milliós akkori lakosság több mint tíz százaléka áldozatul esett az erőszakhullámnak. $^{315}$

Miért is nevezhető népirtásnak, ami Burundiban történt 1972-ben? Egy etnikai csoport tagjait megölték, a csoport teljes vagy részleges kiirtása céljából. A speciális szándékról, a dolus specialisról árulkodik az erőszakhullám szisztematikus, tervezett jellege, egész országra és a társadalom minden szegmensére (hadsereg, egyház, oktatás, állami szervek) kiterjedő végrehajtás. Szintén racionális „,programra” utal az áldozatok tudatos megválasztása, hiszen országszerte „csak” az értelmiségi, tanult hutukat végezték ki (az más kérdés, hogy egy középiskolai tanuló hogyan számíthat értelmiséginek, de ahogy a hutu definíciója, a „tanult” hutu definíciója is egyre radikálisabb jelleget öltött, illetve régiónként változott a népirtás kibontakozása során).

A hutu entellektüelek általában azt állítják, hogy a kormány „,megrendezte” az 1972 áprilisi felkelést, hogy megfelelő ürügye legyen az ú.n. Simbananiye-terv végrehajtására. Artémon Simbananiye volt a külügyminiszter a genocídium idején. A hutu érvelés lényege, hogy a hutukat provokálták, a provokáció végső célja pedig az volt, hogy a felkelés ürügyén egyszer és mindenkorra megszabadítsák az országot a hutu veszélytől. A szándékos provokációra semmilyen bizonyíték nincs, az viszont valóban nyilvánvaló, hogy a tanult hutu áldozatok személyének megválasztása tudatos döntés eredménye. Simbananiye a tervezésben valószínüleg együttmüködött a bel- és igazságügyminiszter Albert Shiburával és az uralmon lévő Union Pour le Progrès National (UPRONA, Unió a Nemzeti Fejlődésért) párt főtitkárával, André Yandával. Shibura és Yanda mindketten kulcspozíciót töltöttek be a hadseregnél. Szintén fontos szerepet játszott a katonai tervezésben Joseph Rwuri, az elnök katonai tanácsadója, illetve Thomas Ndabememye vezérkari fönök.

Minden tanult hutu megölésével vagy elüldözésével a belátható jövőben gyakorlatilag megszünt egy következő hutu felkelés veszélye. A hutu értelmiséghez tartozónak tekintették a közszolgákat, egyetemi hallgatókat, de bizonyos esetekben az iskolás gyerekeket is. Ahogy Jeremy Greenland beszámolt róla: „A kormányzati rádióadó arra biztatta az embereket, hogy ,vadásszák le a pitont a füben”, amelyet a tutszik úgy értelmeztek, hogy öljenek meg minden tanult hutut, a középiskolás, de néha az általános iskolás szintig. A hadsereg alakulatai elkobozták a kereskedők teherautóit

${ }^{315}$ Kiraranganiya [1985] 
és egyéb jármüveket, odahajtottak az iskolák elé és egész csoportnyi gyereket vittek el egyszerre. A tutszik listát készítettek hutu osztálytársaikról, hogy megkönnyítsék az azonosításukat." 316 Sokszor a legkegyetlenebb jelenetek éppen az egyetemeken és középiskolákban zajlottak. A tutszik sokszor fizikailag bántalmazták hutu származású osztálytársaikat, gyakran akár halálos sérüléseket is okozva. „Hivatalos” színezetet adott a bántalmazásoknak, amikor a hadsereg teherautókon megérkezett és név szerint szólította majd elszállította a hutu tanulókat.

Bujumburában, Gitegában és Ngoziban minden hutu közszolgát, sofört, irodai dolgozót, betanított munkást felsorakoztattak, elvittek a legközelebbi börtönbe és vagy lelőtték vagy addig verték őket, míg meghaltak. Csak Bujumburában mintegy négyezer hutut vittek teherautókon tömegsírjukhoz. ${ }^{317}$

Ezt a sok embert kívánó feladatot a hadsereg nem egyedül végezte, segítségükre volt az Uprona kormánypárt ifjúsági szárnya, a különösen erőszakos Jeunesses Révolutionnaires Rwagasore (Rwagasore Forradalmi Ifjúság). A hutuk elleni genocídiumban való aktív részvételhez először meg kellett semmisíteni a JRR hutu tagságát (több száz fiatal), erre a népirtás kezdetén sor is került. A JRR eleinte csak segédkezett a hadseregnek délen, azonban ahogy az atrocitások elérték az északi országrészt, a JRR egyre nagyobb önállóságot mutatott. Saját döntéseik alapján hutuk ezreit állították elő, tartóztatták le. Bujumbura börtönében számos tömeges kivégzést a JRR hajtott végre. Bizonyos források szerint az északon zajló atrocitásokba a tutszi menekülttáborokban élők is besegítettek (akik az 1959-62 között zajló hutu forradalom idején hagyták el Ruandát), de hogy milyen mértékben, arról nincs adat. ${ }^{318}$

$\mathrm{Az}$ emberölésben természetesen a Burundiban élő tutszi civil lakosság is aktívan részt vett. Hiba lenne azonban azt gondolni, hogy minden tutszi önszántából csatlakozott a népirtás elkövetőihez vagy a csendes szemlélőkhöz. Michael Hoyt, az amerikai nagykövetség első megbízottja 1972-ben így fogalmazott május 27-i sürgönyében: „Megbízható jelentéseink vannak, hogy tutszikat, akik követelik az erőszak leállítását, mert túl messzire ment, letartóztatnak, és azonnal kivégeznek." ${ }^{319}$

A felelősséget tehát nem lehet minden tutszi lakosra kiterjeszteni. Maga Boniface Kiraranganiya, Az Igazság Burundiról c. könyv tutszi szerzője is átállt például a hutuk

\footnotetext{
${ }^{316}$ Greenland, Jeremy [1976], 120.old.

${ }^{317}$ Lemarchand, René [2009]

${ }^{318}$ Lemarchand, René [2008]: The Burundi Killings of 1972. Online Encyclopedia of Mass Violence Sciences Po http://www.massviolence.org/IMG/article_PDF/The-Burundi-Killings-of-1972.pdf

${ }_{319}$ Hoyt, Michael. [1972]: US Embassy Cables from Bujumbura to State Department. Unpublished materials available from the University of Florida Libraries, Gainesville, 1. old.
} 
oldalára. ${ }^{320}$ Sok tutszi azonban az életével fizetett a hutuk védelmezéséért. De ugyanez igaz azokra a hutukra is, akik a felkelés kezdetén tutszi sorstársaikat rejtegették. A népirtás elkövetői nagyrészt a hadsereg és a JRR voltak. Ha nem tudtak elegendő létszámban megjelenni valahol, akkor fegyvereket és ölésre buzdító parancsokat osztogattak a helyi tutszi férfi lakosságnak. Ahogy Lemarchand fogalmaz, a félelem légkörében szinte minden tutszi lakos állampolgári kötelességévé vált, hogy hutukat öljön. ${ }^{321}$ Hoyt sürgönyei ${ }^{322}$ remek képet festenek erről a hátborzongató hangulatról: „Nincs haladék, nincs megállás. Nyilvánvaló népirtás folyik. Egyik letartóztatás a másik után.” (május 26.) A hutuk likvidálása folyik tovább. A katolikus misszionáriusok egyre inkább undorodnak. Naponta hallunk olyan történeteket, amelyeket csak betegnek nevezhetek: sok hutut élve égetnek el. Az egyik forrásom 1400-1500-ra teszi a férfi halálos áldozatok számát csak a Rutovu környéki megtorlásokban. A legkíméletesebb kivégzési mód a kőtörő kalapács használata. Mwaro és Bukirasaz között a hadsereg megölte a hutu férfiakat, a tutszi civilek pedig megölték a gyerekeket és a nőket. A halálozás ezrekben mérhető.” (június 10.) „A tutszi megtorlás háborítatlanul folytatódik az ország belsejében, de valamennyit csillapodott Bujumburában. Északon a hutuk azonnal elrejtőznek, ha bármilyen jármü érkezik, átható félelmet mutatva.” (július 11.) „A július 14-ét követő két napon három új árkot tömtek tele hutu holttestekkel a Bujumbura reptér közelében. A hét folyamán folytatódtak a letartóztatások Bujumburában, a város körüli hegyekben, a Ngozi régióban és Közép-Burundiban” (július 21.) „A hutuk elleni elnyomás nem csak a meggyilkolásukat jelenti. Ez egy kísérlet, hogy megtagadják tőlük a munka, tulajdonlás, oktatás és úgy általában a fejlődés lehetőségét." (július 25.)

Boniface Kiraranganiya így jellemezte a népirtást: „A téboly kitörése volt ez, a legeklatánsabb példa arra, hogy mire képes az ember, ha a hatalma lehetővé tesz bármit, amikor nincs semmiféle kötelezettsége, hogy uralkodjon pusztító ösztönein.”323

Az erőszakhullám a társadalom minden részére kiterjedt, nem kímélte a hadsereget, de az egyházat sem. Hoyt a hadseregen belüli tisztogatásokról is hűen beszámolt: „A hutuk kivégzése miatti halálozási arány nőtt a hadseregben. Mostanában megjelent belga becslések ötszázra teszik a halottak számát, Mintegy 150 hutut végeztek ki május 22-én éjszaka, 41-et 27-én éjszaka. A hutu definíciója mindenesetre megváltozott. Most

\footnotetext{
${ }^{320}$ Kiraranganiya [1985]

${ }^{321}$ Lemarchand [2009], 329.old.

${ }^{322}$ Hoyt [1972]

${ }^{323}$ Kiraranganiya [1985], 25.old.
} 
már egyetlen nagyszülő is elegendő ahhoz, hogy egy katonát hutunak bélyegezzenek. Ha ezt a meghatározást használjuk, akkor a hadseregben mintegy száz hutu volt még életben május 23-án."324

Az ellenségeskedés oka számos esetben személyes ellenségeskedés, vagy anyagi haszonszerzés volt. Az elhunyt anyagi javainak megszerzése erőteljesen motiválta a civil lakosságot az atrocitásokban való aktív részvételre. Greenland állítása szerint „Számos esetben a bútorokat elvitték a letartóztatott hutuk házából, az özvegyek és árvák a padlón ültek. A gazdagabb hutuk autója és teherautója azok tulajdonává vált, akik letartóztatták őket." 325

Biztos, hogy a tutszik közül sokan túlélésükre nézve halálos és azonnali fenyegetésként élték meg az áprilisban kirobbant hutu felkelést. Ök támogatták a hutu elit gyökeres eltávolítását, mert úgy látták, hogy ez a végleges megoldás alkalmas csak a halálos veszély elhárítására.

\subsection{A nemzetközi közösség reakciója}

Burundiban néhány hét alatt emberek százezreit ölték meg módszeresen. A tragédia kolosszális mérete ellenére Európa és Amerika csendes maradt. Sokak számára Burundi túlságosan marginális szerepet töltött be Afrikában, mások a megbízható információk hiánya miatt nem emelték fel a hangjukat. Számos szakértő és politikus egyszerủen az ország belső ügyének tekintette a vérontást, voltak, akik azt állították, hogy az atrocitások súlyosságának felemlegetésével csak a Dél-Afrikára irányuló figyelmet akarják elterelni.

A következőkben a nemzetközi közösség érintett tagállamainak, valamint az Egyesült Nemzetek Szervezetének és az Afrikai Egységszervezetnek a válságra adott válaszát tekintjük át, részletesen kitérve arra, hogy mi lehetett a megelőzés kudarcának oka.

\subsubsection{Az Amerikai Egyesült Államok}

$\mathrm{Az}$ Amerikai Egyesült Államok reakcióját talán a Carnegie Endowment for International Peace a Burundiban zajlott népirtásra adott amerikai választ elemző

\footnotetext{
${ }^{324}$ Ibid., 2.old.

${ }^{325}$ Greenland [1976], 122.old.
} 
jelentése foglalja össze leginkább: az Amerikai Egyesült Államok hivatalos hozzáállása a kérdéshez egyszerre árulkodott „közönyről, tehetetlenségröl és felelőtlenségről.”326

Azt semmiképp sem lehet mondani, hogy a Külügyminisztériumnak nem álltak rendelkezésére a megfelelő információk. A diplomáciai képviseleten dolgozó Michael Hoyt részletes sürgönyei elegendő részletet közöltek a kialakult helyzetröl. Henry Kissinger szeptemberben össze is foglalta az elmúlt hónapok eseményeit az elnöknek Richard Nixonnak készült jelentésében. ${ }^{327}$ Ebben a jelentésben Kissinger tájékoztatja Nixont, hogy április 29-én egy csapat hutu megpróbált felkelést indítani az uralkodó tutszi törzs ellen. A felkelés nem sikerült, de véres megtorlást váltott ki, amely több mint százezer hutu halálához vezetett, és közel félmillió hutu özvegyet és árvát hagyott maga után. Kissinger a Burundiban zajló „háború” okaként törzsi konfliktust jelöl meg: „úgy tűnik, hogy a burundi tragédia kifejezetten belső, törzsi ügy”. Kissinger azt is hangsúlyozza ebben a jelentésben, hogy egyetlen afrikai vezető sem szólalt fel nyilvánosan a vérengzés ellen, és nem próbálták bevonni az ENSZ-t vagy az Afrikai Egységszervezetet, ezzel szemben az Amerikai Egyesült Államok a színfalak mögött próbálta rávenni az afrikaiakat, hogy vigyék az ügyet az Afrikai Egységszervezet elé. Mobutu ezt megfontolás tárgyává tette, a többi afrikai elnök azonban, többek között Szelasszié, Ahidjo és Nyerere, nem akart beleavatkozni Burundi belügyeibe. Az, hogy Belgium nyilvánosan elítélte a Burundiban zajló népirtást, leállította a katonai segítségnyújtást és lelassította a gazdasági segélyezést, csak minimális hatást gyakorolt a tutszi kormányra. Kissinger szerint más európaiak „nem akartak belekeveredni” a dologba.

$\mathrm{Az}$ amerikai érdekeket Kissinger mikroszkopikusnak nevezi jelentésében, 150 amerikai lakossal a helyszínen, akiknek maga a burundi kormány garantálta a biztonságát. A kereskedelmi kapcsolatokat a következő zárójeles megjegyzéssel: „egy kevés kávét vásárolunk tőlük”.

Kissinger szerint az amerikai külpolitika célja, hogy Burundinak humanitárius segítséget nyújtson, ha az eljut a teljes lakossághoz, illetve támogassa az országhatáron kívül került menekülteket.

Kissinger jelentésére Nixon elnök egy hosszabb lélegzetü, kézzel írott jegyzettel válaszolt: „Ez az egyik legcinikusabb, legkegyetlenebb reakció, amelyet valaha láttam

326 Brown, Michael, Freeman, Gary, and Miller, Kay [1973]: Passing-By: The United States and Genocide in Burundi, 1972. New York: The Carnegie Endowment for International Peace

327 The White House, Washington, September 20, 1972. Memorandum for the President from Henry A. Kissinger, Subject: Burundi 
egy remek kormány részéről erre a borzalmas emberi tragédiára. Amikor a pakik megpróbálják leverni a kelet-pakisztáni felkelést, a világ sikít. Amikor az indiaiak megölnek néhány ezer pakit, senkit sem érdekel. Biafra felkavar bennünket a katolikusok miatt, az izraeli olimpia a zsidók miatt. [...] De amikor 100.000 embert meggyilkolnak, nem mondunk semmit, mert nem akarunk rosszat szólni a feketékről (kivéve persze, ha katolikus feketéket öldökölnek). Nem veszi be a gyomrom ezt a kettős mércét. Mondja meg az Afrikai Részlegnél dolgozó gyenge szívü munkatársaknak, hogy legalább arra tegyenek ajánlást, hogyan mutassuk ki erkölcsi felháborodásunkat. És kezdjük azzal, hogy azonnal visszahívjuk a nagykövetünket. Semmilyen körülmények között sem fogok beleegyezni, hogy egy új nagykövet ezekkel a mészárosokkal írassa alá a meghívólevelét., ${ }^{328}$

A Külügyminisztérium azonban nem tartottan szükségesnek az amerikai nagykövet visszarendelését, hiszen az atrocitásoknak már vége. ${ }^{329}$

Mivel az elnök nem találta megfelelőnek az amerikai választ a burundi népirtásra, Theodore L. Eliot, Jr., a Külügyminisztérium Afrika Osztályának titkára három nappal később, 1972.szeptember 24-én Henry Kissingernek írott jelentésében részletezte az amerikai fellépést, mintegy mentegetve a Külügyminisztériumot a közönyéért. ${ }^{330}$

Eliot szerint májusban és júniusban Amerika az európai országokkal és néhány afrikai állammal együtt próbált akadályozni a további vérontást és elérni, hogy a segélyszervezetek akadálymentesen müködhessenek, az afrikai országok hozzáállása azonban elzárkóztak, belső ügynek tekintették a vérontást. Általánosságban Micombero burundi elnök érvelését támogatták, aki szerint az akció a hutu felkelés leverése miatt szükséges.

Eliot kiemeli, hogy az első konkrét diplomáciai lépés a nemzeti megbékélésre felhívó levél volt, amelyet Burundi nyugati nagykövetei írtak alá. Az országban dolgozó

\footnotetext{
${ }^{328}$ Source: National Archives, Nixon Presidential Materials, NSC Files, Box 735, Country Files, Africa, Burundi, Vol. I. Administratively Confidential. Összeállította F. E. Rondon, egy jelentés alapján, amelyet Rondon és Richard Kennedy szeptember 20-án elküldtek Kissingernek.

329 "Rogers doesn't want to do it because he says the killing there has potentially stopped now.”- „Rogers [amerikai külügyminiszter] nem akarja [visszahívni a nagykövetet], mert azt mondja, az öldöklésnek már valószínüleg vége.”- Nixon elnök és Kissinger közötti beszélgetés, September 23, 1972, 4:50 - 5:10 p.m Forrás: National Archives, Nixon Presidential Materials, White House Tapes, Camp David Secretary's Table, Conversation No. 154-3.

${ }^{330}$ Eliot memoranduma Kissingernek, Washington, September 24, 1972, Forrás: National Archives, Nixon Presidential Materials, NSC Files, Box 735, Country Files, Africa, Burundi, Vol. I. Confidential.
} 
nyugati diplomataták azonban nem is voltak beszélőviszonyban egymással. ${ }^{331}$ Sikerült ugyan megfogalmazniuk egy tiltakozó levelet a kormány akciójával szemben, de a nézetkülönbségek miatt nagyon enyhe hangvételü lett, ${ }^{332}$ és semmiféle hatást nem gyakorolt a kormányra.

Eliot arra is kitér jelentésében, hogy az amerikai diplomaták a színfalak mögött állítólag igyekeztek meggyőzni az afrikai vezetőket, hogy nyomást gyakoroljanak Burundira. Afrikai kezdeményezés hiányában amerikai diplomaták felkeresték Zaire, Etiópia, Tanzánia, Ruanda és Mauritánia elnökét. Ezután a zairei Mobutu és a tanzániai Nyerere találkoztak Burundi elnökével, Micomberoval, és sürgették az öldöklés végét.

$\mathrm{Az}$ Amerikai Egyesült Államok Belgiummal is konzultált, a belgák amerikai sürgetésre felhagytak a fegyver- és töltényszállítással, amellyel ők látták el korábbi gyarmatukat, Burundit.

Amerika állítólag az ENSZ Titkárságát is biztatta a közvetlen beavatkozásra. Többek között ennek köszönhető, hogy Waldheim ENSZ-fötitkár júniusban a rabati Afrikai Egységszervezet-csúcson személyesen elbeszélgetett a burundi külügyminiszterrel. Mindez azonban a színfalak mögött folyt, és nyilvánosan senki sem ítélte el a Burundiban zajló eseményeket.

Eliot a humanitárius segélyezésre is külön kitér Kissingernek írott memorandumában. Eszerint a burundi kormány nemzetközi segítséget kért, és kapott. $\mathrm{Az}$ amerikai kormány 100.000 dollárral támogatta Burundit. Belgium, Nyugatnémetország, Peking és Zaire szintén jelentős hozzájárulásokat ajánlottak fel. Amint nyilvánvalóvá vált, hogy a hutuk masszív elnyomása zajlik a nemzetközi humanitárius akciók célcsoportjait rájuk is kiterjesztették. Ezen a ponton azonban a burundi kormány elkezdte akadályozni a segélyezőket, ragaszkodott hozzá, hogy minden segélyszállítmány csak tutszik lakta területre juthat el. Amerikai a menekülteket is 50.000 dollárral támogatta.

\footnotetext{
${ }^{331}$ Lemarchand, René [1998]: Yale Center for International and Area Studies, Working Paper Studies. Genocide Studies Program: Genocide in the Great Lakes: Which Genocide? Whose Genocide? USAID/Accra, 1998

332 „Mint Burundi igaz barátai, aggodalommal és nyugtalansággal figyeltük az elmúlt hetek eseményeit. Így megnyugtatott bennünket a „bölcsek csoportjának” kinevezése az ország békéjének helyreállítása érdekében, valamint az egyének és csoportok önkényes akcióit elítélő, és a személyes bosszúból és hatalmi túlkapásokból fakadó cselekményeket korlátozó intézkedések sorozata.” [Forrás: Hoyt, May 30, 1972, In: Hoyt, Michael [1972]: U.S. Embassy Cables from Bujumbura to State Department, April 29August 29, 1972, www.uflib.ufl.edu/cm/africana/fulltext.htm]
} 
Eliot szerint tehát Amerika az „aktív, csendes nemzetközi erőfeszítések vezetőjeként lépett fel”, akcióikat hátráltatta „az afrikai hozzáállás, valamint az európai kormányok vonakodása [...]”333

\subsubsection{Belgium és Franciaország}

A nyugati hatalmak közül Belgium volt az, aki leginkább megpróbált érdemben tiltakozni. Miután a belga közvélemény és a belga parlament kritizálta a kormányt, hogy az atrocitások ellenére továbbra is segítséget nyújt a burundi kormánynak, a külügyminiszter bejelentette, hogy az együttmüködést átalakítják a körülményeknek megfelelően.

Belgium a népirtás miatt, a belső és külső (amerikai és más kormányok) nyomás hatására felfüggesztette a fegyverszállítást Burundiba, korábban ugyanis nagyrészt ő látta el fegyverrel, tölténnyel és utánpótlással a kormányerőket.

Júliusban a belga kormány figyelmeztette a burundi kormányt, hogy a bilaterális tanári egyezmények keretében a belga nagykövet az ország bármely részén meglátogathatja a Burundiban dolgozó belga tanárokat, ebbe Burundi nem egyezett

${ }^{333}$ Az elnök és általában az amerikai kormány érthetetlen közönyét és távolságtartását jól érzékelteti az alábbi beszélgetés Nixon és Kissinger között 1972. szeptember 24-én, amelyben az elnök arról igyekszik meggyőzni főtanácsadóját, hogy a Burundiban élők is emberek:

„Nixon: Henry, az egész Burundi-ügyben- én figyeltem, a sajtóban. Tudta, hogy egyetlen beszámolót sem küldtek nekünk erröl a külügyböl?

Kissinger: Teljesen igaz.

Nixon: Vagy küldtek? Maga látott valamit, amit én nem?

Kissinger: Nem, nem. Nem küldtek.

Nixon: Na és mi a véleménye erről?

Kissinger: Hát én [...]

Nixon: Nem érzi, és legyen teljesen öszinte, hogy egy ember az egy ember az isten verje meg? Tudja, vannak azok, akik úgy beszélnek a vietnámiakról, mint messze élő emberekről, akikről nem tudunk semmit. És emlékszik, ahogy szegény öreg Chamberlain nyilatkozott a csehekröl. Hogy messze vannak, és ,nem ismerjük őket túl jól”. Na de az isten verje meg, egy ember akkor is ember az én véleményem szerint.

Kissinger: Hát, nem csak erről van szó...

Nixon: Nem arról van szó, amikor a nemzeti érdekeink forognak kockán. De minden egyes alkalommal, amikor bárki más is belekeveredik - tudja egy másik egyén vagy mi, máris alakul egy kis lobbicsoport, és a külügy falra mászik. De nekem kezd elegem lenni ebből, hogy hagyjuk az afrikaiaknak, hogy lemészároljanak százezer embert és semmit nem teszünk ellene.

Kissinger: És aztán itt van ez a rengeteg vérző szívű amerikai, akik azt állítják, hogy mi örömmel öljük a sárgákat..

Nixon: Igaz.

Kissinger: Nem öltünk meg nyolc év alatt annyit, mint Burundiban három hónap alatt.

Nixon:[...] A helyzet az, hogy a külügy álláspontja, Newsom [David Newsom, Külügyminisztérium Afrikai Ügyosztály, Afrikai ügyekért felelős külügyminiszterhelyettes] álláspontja az, hogy mindig kiáll a hatalmon lévő fekete kormányok mellett, legyenek bármilyenek. Igazam van vagy nem? Kissinger: Teljesen igaza van.”

[Forrás: Beszélgetés Nixon és Kissinger között, Camp David, September 24, 1972, 11:37-11:52 a.m, National Archives, Nixon Presidential Materials, White House Tapes, Camp David Secretary's Table, Conversation No. 154-7.] 
bele. Ha a belga nagykövet az ország vidéki részeit is felkeresi, nyilvánosságra kerültek volna a népirtás részletei.

Belgium tiltakozásképpen a katonai jelenlétét is felfüggesztette: a Burundiban tartózkodó, az ország különböző részeire kihelyezett katonákat egy helyre rendelték, majd később kivonták az országból. ${ }^{334}$

Franciaország igyekezett kihasználni Belgium visszavonulását. A francia attitűdöt a nemtörődömség és opportunizmus keveréke jellemezte, valamint a frankofóniához való mindenáron való ragaszkodás. Az, hogy a tutszi felsőbbrendüség nevében éppen százezreket gyilkolnak meg, a legkevésbé sem hatotta meg a francia vezetést. Öket az foglalkoztatta, hogy a francia kulturális értékeket, illetve a francia nyelv használatát és ismeretét előmozdítsák, a francia befolyási övezetet növeljék Fekete Afrikában. Mivel a franciák a tutszikat összességében rátermettebb népcsoportnak tartották, mint a hutukat, valamint a tutszik szívesebben üzleteltek a franciákkal, őket egyébként is gyümölcsözőbb „,befektetésnek”, megfelelőbb partnernek tartották a francia diplomaták. ${ }^{335}$

Talán ennek is köszönhető, hogy a franciák a kultúra, oktatás és technika területén éppúgy igyekeztek jelen lenni Burundiban, mint katonai szempontból. Ahelyett, hogy megfontolták volna a kivonulást, vagy legalább a helyzet elleni tiltakozást, igyekeztek kihasználni a belga „térvesztést”. Amikor például Belgium az oktatási egyezményen keresztül próbált nyomást gyakorolni a burundi kormányra, a franciák rögvest jelezték, hogy szívesen pótolnák a kiesett anyagi forrásokat.

Franciaország katonailag is bizonyítottan támogatta a rezsimet a felkelés alatt és után is. Egy megfigyelő így fogalmazott a francia katonai szerepvállalással kapcsolatban:

„Francia katonai segítők vezették és vezetik a rezsim helikoptereit. Ez a légi segítség kulcsszerepet játszott a déli felkelők kifüstölésében. [...] Franciák tartották egy helyben a helikoptereket, míg burundi katonák géppisztollyal céloztak a hutu felkelőkre az oldalablakból [...]"336

\footnotetext{
${ }^{334}$ Belgium's reaction to the Burundi Situation. Memorandum az elnöknek Henry Kissingertöl, September 29, 1972. http://2001-2009.state.gov/documents/organization/53886.pdf

${ }^{335}$ Lemarchand, René [1975]: Ethnic genocide. In: ISSUE: A Quarterly Journal of Africanist Opinion Volume V, Number 2, Summer 1975

${ }^{336}$ Ibid.
} 
Franciaország tehát az egész népirtás kapcsán kialakult helyzetet igyekezett a maga javára fordítani, és további teret nyerni Fekete Afrikában a frankofónia jegyében, akár azon az áron is, hogy kétes kormányerőkkel müködik együtt.

\subsubsection{Afrikai Egységszervezet, ENSZ}

Az Afrikai Egységszervezet hivatalosan nem ítélte el a népirtást. 1972. május 22-én, amikor a népirtás még gőzerővel folyt, a főtitkár Diallo Telli Bujumburába látogatva így fogalmazott: „Az Afrikai Egységszervezet alapvetően a szolidaritásra épülő szervezet, így jelenlétem Bujumburában a fötitkárság Burundi elnökével, kormányával és népével szembeni teljes szolidaritását mutatja." Ez a cinikus nyilatkozat azonban nem jelenti feltétlenül azt, hogy az afrikai kormányok vagy egyének mindannyian egyetértettek a burundi kormány stratégiájával. Sok afrikai értelmiségi különösen károsnak tartotta, hogy egy afrikai kormány elnyomja a saját népét, tömeges emberi jogi jogsértéseket követ el, amikor egész Afrika a koloniális elnyomás utóhatásai és elvei ellen küzd. Az alábbi részletek afrikai újságokból származnak:

„A Burundiban zajló erőszakhullámban az a legszánalmasabb, hogy feudális uralmat megszüntető, felmagasztalt forradalom nem hozott igazi változást az uralkodó tutszik és a hutu többség kapcsolatában. [...] A kormánynak minden más társadalmi csoportnál inkább magára kellene vállalnia, hogy a kormány által is tisztelt forradalmi elveknek megfelelően az évszázadokon át szenvedő hutu népesség helyzetén javítson.” (Daily Nation, 20 June 1972.)

A Burundiban zajló erőszakhullám] a legnagyobb tragédia a polgárháborúnk óta. Afrika nem engedheti meg magának, hogy kettős mércét alkalmazzon, vagy olyan benyomást keltsen, hogy elnézi a pogromokat, ha azok önálló afrikai országokban zajlanak. [Micombero elnöknek fel kellene fognia] hiába reménykedik abban, hogy a kisebbség a végtelenségig elnyomhatja a többséget. (New Nigerian, 21 June 1972.)

1972. június 20-án, az Afrikai Egységszervezet rabati konferenciáján azonban ismét született egy hivatalos állásfoglalás Burundival kapcsolatban az Afrikai Egységszervezet részéről, amely a Micombero-rezsim teljes támogatását jelzi: „A Miniszerek Tanácsa meg van győződve, hogy az Önök megmentő akciójának köszönhetően a békét és a nemzeti egységet sikerül gyorsan helyreállítani, és a területi egységet megőrizni.",337

${ }^{337}$ Lemarchand [1975] 
Mi lehet a magyarázat az afrikai közönyre? Valószínűleg egyik nemrég függetlenségét elnyert afrikai ország sem szeretett volna precedenst teremteni, hogy aztán amikor adott esetben hasonló problémája van, neki is külső szereplők diktáljanak. René Lemarchand Selective Genocide in Burundi ${ }^{338}$ c. cikkében úgy fogalmaz, hogy minden afrikai ország többé-kevésbé potenciális Burundi, és a külső intervenciótól tartva inkább nem hallatja hangját a kontinens kormányai ellen.

Ami az ENSZ szerepét illeti: az Amerikai Egyesült Államok többször is utalt rá, hogy az ENSZ-jelenlét megakadályozhatná a további vérontást. Az ENSZ küldött is két missziót, összesen öt(!) emberrel. Amikor kiderült, hogy milyen kis létszámban küldött megfigyelőket az Egyesült Nemzetek Szervezete, egy magas rangú amerikai hivatalnok így fogalmazott: „Nem voltak többé illúzióink arról, hogy az ENSZ mit is tud véghezvinni'" 339

Az ENSZ főtitkára, Kurt Waldheim sem vitte túlzásba a Micombero-rendszer kritikáját: hangsúlyozta, hogy „élénken reménykedik a béke, harmónia és stabilitás gyors és sikeres helyreállításában, hogy Burundi eléri szociális fejlődéssel kapcsolatos céljait, magasabb életszínvonalat és az ENSZ Kartában lefektetett elveket."340

Ha ez nem lett volna elég, és teljesen ellentétes az ENSZ alapelveivel, ráadásul az ENSZ teherautóit is rekvirálták a burundi hatóságok és sok esetben azzal szállították a hutu holttesteket a tömegsírokhoz. „Ironikus volt látni, hogy UNICEF feliratú Land Rovereket erre a célra használnak" ${ }^{341}$-írta egy szemtanú, Jeremy Greenland. Találhatunk-e ennél illusztrisabb példát az Egyesült Nemzetek Szervezetének passzivitására?

Mi lehet a magyarázat erre az általános közönyre? Az 1970-es években még dúlt a hidegháború, és Burundi a megoldandó nemzetközi problémák között a sor végén kullogott. Amerika éppen újabb bombázási hullámot indított Vietnám ellen. Mivel itt nem volt szó arról, hogy a hutuk, esetleg a tutszik kommunista vagy nyugati szimpatizánsok lettek volna, egyik oldal sem tartotta fenyegetésnek a genocídiumot a saját nemzeti érdekeire nézve.

\footnotetext{
${ }^{338}$ Lemarchand, René [1974]: Selective Genocide in Burundi, Report No. 20, Minority Rights Group, London 1974

${ }^{339}$ Ibid.

${ }^{340}$ Idézte Teltsch, Kathleen [1972]: Killings Go on in Burundi, July 20., 1972 The New York Times

${ }^{341}$ Greenland, Jeremy: Burundi: the tragic years (an eyewitness account) African Affairs, London, 1975 74 (297): 502
} 
A szomorú igazság, hogy Burundi 1972-ben túl messze volt, és túl egzotikusnak és jelentéktelennek ítéltetett a nemzetközi arénában. Szerepe olyannyira marginális volt, hogy nem keltett sem együttérzést, sem aggodalmat sem nyugaton, sem keleten. ${ }^{342}$

Ahhoz, hogy a Micombero-rendszerre a genocídium befejezése érdekében hatékony nyomást lehessen gyakorolni, a rendszerrel együttmüködő minden nyugati hatalom összehangolt akciójára szükség lett volna. Ha az erkölcsi figyelmeztetés és a gazdasági szankciók összekapcsolódtak volna, akkor talán csökkenteni lehetett volna az áldozatok számát. A Carnegie Endowment for International Peace 1973-as tanulmányában kiemelték, hogy mivel Burundi kávétermelésének nyolcvan százalékát az Egyesült Államok vásárolta meg (ami az ország külföldi bevételének mintegy hatvan százalékát tette ki), Amerikának alkalmaznia kellett volna a „kávéfegyvert”. 343 Kétséges, hogy egy ilyen jellegü gazdasági szankció rövid távon hatékony lett volna-e a népirtás megakadályozásában. Ahogy Lemarchand is megjegyzi, egy ilyen gazdasági szankció hatásától az ország hutu és tutszi lakosai is ugyanúgy szenvedtek volna, ráadásul előbbutóbb akadt volna más jelentkező a felesleges kávéra. ${ }^{344}$ Ez a példa, valamint a Belgium anyagi és erkölcsi támogatását lelkesen pótló Franciaország illusztrálja, hogy csak a nemzetközi közösség többé-kevésbé összehangolt és gyors akciója esetén számíthatunk hatékony megelőzésre.

\subsection{A népirtás hosszú távú hatása}

$\mathrm{Az}$ elkövetők határozott célok miatt hajtották végre a népirtást. Egyrészt biztosítani akarták a stabilitást a lehetséges „zavaró” elemek (hutu elégedetlenkedők) kiiktatásával, meg akarták változtatni az erőviszonyokat a hutu elit megsemmisítésével, valamint a társadalom szemében úgy akartak feltünni, mint az a kormány, amely megvédi őket mind a külső, mind a belső ellenségektől, és biztosítja a túlélésüket. Ezeket a célokat a népirtás szervezői sikeresen teljesítették. Ellentétben tehát az 1994-es ruandai népirtással, középtávon „sikeresnek” tekinthető a népirtás. A tutszi politikai hegemóniát sikerült biztosítani a következő tizenhat évre.

Mindkét népcsoport lelkében mély nyomot hagytak az 1972-ben történtek. A hutu radikalizmus melegágyává váltak az 1972-es népirtás kapcsán Burundit elhagyó hutu

\footnotetext{
${ }^{342}$ A kommunista hatalmak közül Észak-Korea és Kína hivatalosan is támogatták a Micombero-rendszert, a szovjetek pedig (habár nem voltak a Micombero-rezsim szövetségesei) szintén nem írták alá például a nyugati diplomaták tiltakozó levelét.

${ }^{343}$ Brown, Michael, Freeman, Gary, és Miller, Kay [1973]: Passing-By: The United States and Genocide in Burundi, 1972. New York: The Carnegie Endowment for International Peace

${ }^{344}$ Lemarchand [1975]
} 
menekültek. 1973-ban Tanzániában alakult meg az egyik legradikálisabb tutsziellenes párt, a Parti de la Libération du Peuple Hutu (Palipehutu, A Hutu Nép Felszabadításáért Küzdő Párt). A hutuk nemcsak Burundiban, hanem az összes környező országban is élénken emlékeznek arra, hogy mit tettek velük a tutszik 1972-ben. Amikor az 1972-es menekültek repatriálása kerül szóba, mindig azok a tutszik tiltakoznak legélénkebben, akik a népirtás során jutottak tulajdonhoz.

Burundiban 1972 után tizenhat évig látszólagos nyugalom honolt, míg 1988-ban újabb véres etnikai összecsapás rázta meg az országot. 1988 augusztusában Ntega és Marangara északi tartományokban hutu felkelés tört ki egy helyi tutszi nemes ellen, több száz tutszi civil áldozatot követelve. A hadsereg ismét véres elnyomással válaszolt, amely mintegy 15000 hutu életébe került.

A nemzetközi közösség az 1972-es passzivitással szemben ezúttal élénken tiltakozott a kormány reakciójával szemben. A fő donorországok pressziója nyomán Burundi kormánya alapvető alkotmányos és politikai reformokat vezetett be.

A liberalizáció felé vezető úton 1993-ban áttörés következett be a többpárti elnöki és parlamenti választások meghirdetésével. Természetesen az etnikai arányokat sokkal inkább reprezentáló eredmény született: elsöprő többséget szerzett a nagyrészt hutu Front des Démocrates du Burundi (Frodebu- Burundi Demokrata Front). Az új hutu elnököt, Melchior Ndadayét azonban tutszi szélsőségesek 1993. október 21-én meggyilkolták, ezzel újabb erőszakhullámba taszítva az országot. Ezeket a tutszi szélsőségeseket támogatták azok a tutszik, akik az 1972-es népirtás idején jelentősebb tulajdont szereztek.

A Frodebu a mérsékelt hutu álláspontot képviselte, de Ndadaye meggyilkolása után egyre több hutu fordult a szélsőségesebb nézeteket hirdető pártok, alakulatok felé. Liisa Malkki 1995-ben megjelent munkája ${ }^{345}$ jól bemutatja, hogy a határokon kívülre szorult hutu menekültek körében hogyan éltek tovább 1972 eseményei és hogyan kapcsolódtak például az 1994-es ruandai népirtásban kulcsszerepet játszó, erőszakra uszító Radio Mille Collines megalakulásához.

A népirtás tovább kristályosította, mit is jelent hutunak vagy tutszinak lenni. Már nem feltétlenül az anyagi státusszal vagy a politikai hatalommal kapcsolódtak össze ezek a megjelölések, hanem az egyes népcsoportok erőszakhullámokban, népirtásban betöltött szerepével. A hutu-tutszi frontvonalak megszilárdultak.

\footnotetext{
${ }^{345}$ Malkki, Liisa. [1995]: Purity and Exile: Transformations in Historical-National Consciousness Among Hutu Refugees in Tanzania. Chicago: University of Chicago Press
} 
A megbékélést gyakorlatilag lehetetlenné teszi, hogy a burundi politikai diskurzus nem ismeri el az 1972-es népirtást. A hivatalos álláspont szerint a népirtó szándékú hutu felkelők jogos leverése zajlott 1972-ben, éppen ezért az akkor események miatt senkit sem vontak felelősségre. Az elmaradt felelősségre vonás pedig olyan súlyos indulatokat szült mindkét oldalon (a tutszik mindenáron el akarták kerülni, míg a hutuk nem tudtak túllépni sérelmeiken), hogy a két népcsoport békés egymás mellett élést a mai napig ellehetetleníti.

Az 1972-es események meghatározóvá váltak az egész régió számára, hiszen a menekültáradat minden szomszédos országot érintett. Számos menekült évtizedeket volt kénytelen menekülttáborokban élni, mert nem térhetett vissza lakhelyére. Több mint negyven év alatt a tulajdonviszonyok nagymértékben átrendeződtek: Burundi kis területü, sürün lakott ország, ahol az erőforrások nem állnak rendelkezésre olyan bőségben, hogy a visszatérő menekültek problémáját megnyugtatóan rendezni lehessen. Az állandó belharc tovább fokozza az egyébként is nyomasztó szegénységet.

Tanzánia, Ruanda és Kongó pedig a menekültáradattal volt kénytelen szembenézni: mintegy 150.000 ember hagyta el Burundit, majd ez a szám a következő néhány hónapban Peter Uvin Közép-Afrika-szakértő szerint 200.000 -re nőtt. ${ }^{346} \mathrm{Az}$ International Crisis Group azonban ennél is magasabb, mintegy 300.000 fös menekültlétszámról számol be. ${ }^{347}$ A legtöbb 1972-es menekültet Tanzánia fogadta be.

A befogadó országok általában átmeneti megoldásként tekintettek a menekülttáborokra, és a menekültek visszatérését igyekeztek elősegíteni és támogatni. Bár voltak csoportok, amelyek sikeresen integrálódtak a helyi társadalomba, a menekültek nagy része évtizedekig táborokban élt, a visszatérésre várva. Sokan Melchior Ndadaye megválasztása után visszatértek Burundiba, majd miután meggyilkolták az elnököt, ismét menekülni kényszerültek. (Ekkor mintegy félmillió burundi hagyta el az országot). ${ }^{348}$

A hutuk és tutszik közötti bizalmatlanság, a múlt tapasztalatain alapuló kölcsönös félelem a mai napig meghatározza a két népcsoport kapcsolatát. Burundi népirtással

\footnotetext{
${ }^{346}$ Uvin, Peter [1999]: Ethnicity and Power in Burundi and Rwanda: Different Paths to Mass Violence. Comparative Politics, 31(3): 253-27.old.

${ }^{347}$ ICG [1999]: Burundian Refugees in Tanzania: The Key Factor to the Burundi Peace Process, Africa Report $\quad \mathrm{N}^{\circ} 12, \quad \mathrm{http} / / / \mathrm{www}$. crisisgroup.org/en/regions/africa/central-africa/burundi/012-burundianrefugees-in-tanzania-the-key-factor-to-the-burundi-peace-process.aspx, [2013.01.20.]

${ }^{348}$ UNHCR [2007]: Group Resettlement of "1972 Burundians" from Tanzania, Burundi Fact Sheet http://www.unrefugees.org/atf/cf/\%7BD2F991C5-A4FB-4767-921F-A9452B12D742\%7D/Burundi factsheet.pdf
} 
megpecsételt történelme tehát a mai napig kísért, és negatívan befolyásolja nemcsak Burundi, hanem a környező országok lakóinak életét.

A következő részben a huszonkét évvel később, 1994-ben bekövetkező ruandai népirtást mutatom be. A hutu és tutszi népcsoport kapcsolatának elmérgesedése tehát néhány évtizeden belül két súlyos, emberek százezreinek életét követelő atrocitást produkált. Ruandában a genocídium ellenkező előjellel zajlott. Míg Burundiban a népirtás a tutszi elit eszköze volt a hutu többség hosszú távú elnyomására, Ruandában a hutu többség akart megszabadulni a nemzetbiztonsági kockázatnak tartott tutszi kisebbségtől. A megelőzés szempontjából különösen fontos kiemelni, hogy míg a Burundiban zajló eseményekről viszonylag kevés információ állt a nyugati kormányok rendelkezésére a népirtást megelőzően, Ruanda esetében tisztában voltak azzal, hogy bizonyos vezetők népirtást terveznek. Ennek ellenére sem sikerült eltéríteni az eseményeket végzetes irányuktól. 


\section{6. fejezet: Népirtás Ruandában - 1994}

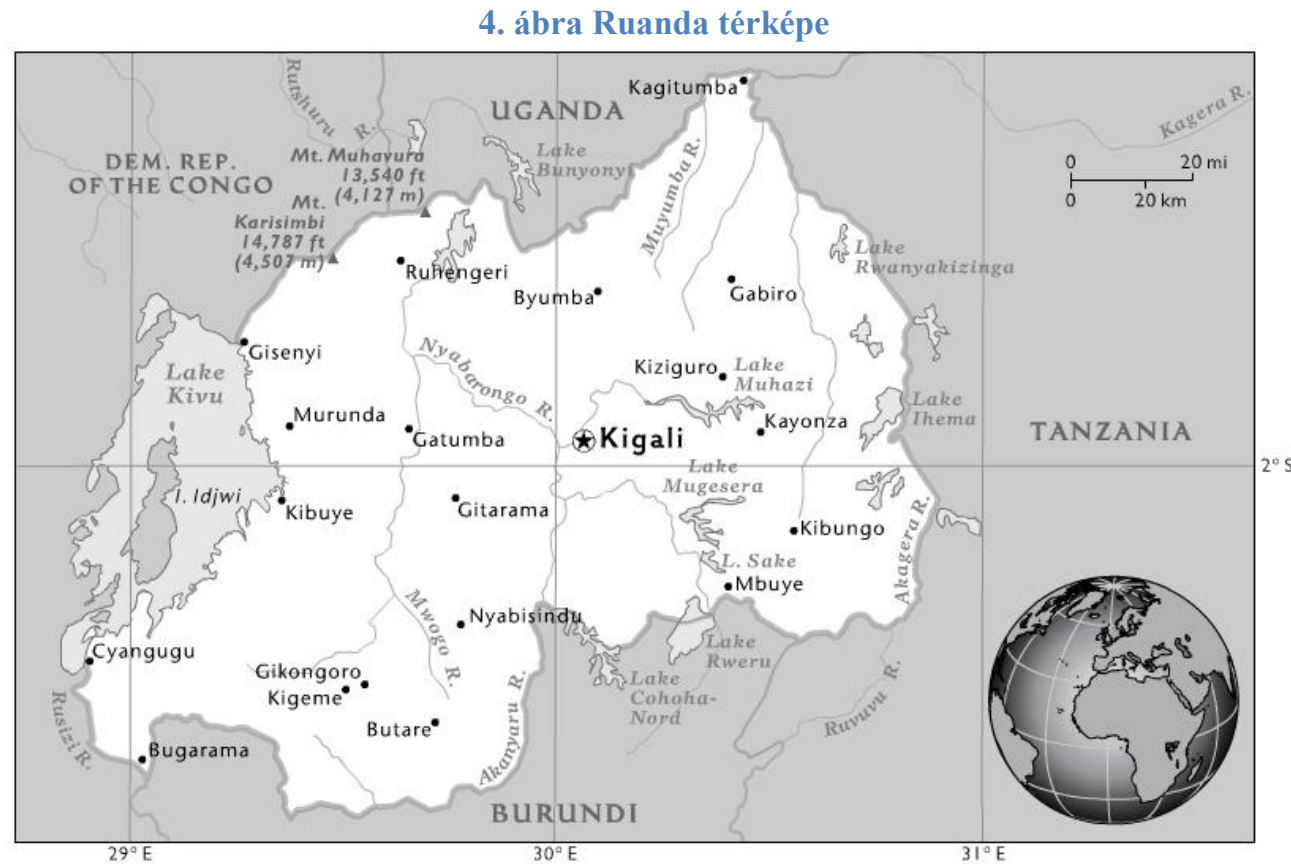

Forrás: National Georgraphic Education (2013): Ruanda

Ruandában az 1994. április 6-i Habyarimana elnök elleni sikeres merénylet utáni tizenhárom hétben mintegy 800.000 ember vesztette életét. A gyilkosok olyan gyorsasággal és eréllyel csaptak le a kisebbséget alkotó tutszikra, hogy sok megfigyelö és szakértő a törzsi erőszak újabb kitöréséről beszélt. A tények ismeretében azonban határozottan cáfolható, hogy az 1994 tavaszán bekövetkezett népirtás a gyülölet természetes kitörése, ősi törzsi ellentétek eredménye lett volna.

Ruanda tutszi lakosságának háromnegyede, és a genocídium ellen tiltakozó hutuk ezrei estek áldozatul az erőszaknak. A politikai elit az etnikai törésvonalakat kihasználva a többséget kiszámítottan a kisebbség ellen fordította, felhasználva az állam bürokratikus felépítését és jól olajozott gépezetét nagyszabású gyilkos tervei végrehajtására.

Ez a genocídium Ruanda elitjének tudatos választása volt, amelyet a hatalom megtartása érdekében hajtott végre.

\subsection{Történelmi háttér}

Ahhoz, hogy megértsük, a két etnikai csoport hogyan fordult egymás ellen, nélkülözhetetlen Ruanda modernkori történelmének megismerése. 
A népirtás elötti Ruanda mintegy hétmilliós lakossága három etnikai csoportból állt: a hutuk alkották a népesség nagy részét (84\%), míg a tutszik tették ki a lakosság 15 százalékát. A harmadik, politikai szempontból meglehetősen jelentéktelen népcsoport a twa volt (1\%), akiket gyakran pigmeusoknak is neveznek.

Ruandában fokozatosan szilárdult meg az a koncepció, mely a tutszi elnevezést a marhatenyésztőkkel, a hutut pedig a földmüvelö, általában valaki más szolgálatában álló népcsoporttal azonosítja. Ruanda történelme során ezen csoportok tagjai általában a saját csoportjuk tagjaiból választottak maguknak házastársat, így fokozatosan külső tulajdonságok is megkülönböztették egymástól a hutukat (alacsonyabbak, erösebb testalkatúak, szélesebb, lapos orral) és a tutszikat (magasak, soványak, keskeny orral). Mivel a gazdagságot marhákban mérték, ${ }^{349}$ ezért a tutszik kezdtek magukra is úgy tekinteni, mint gazdagabb, uralkodásra termett népcsoportra. Ugyanakkor az etnikai jellegzetességek nem voltak „kőbe vésve”: a gazdagabb hutuk tutszivá válhattak, elörelépve a társadalmi ranglétrán. Míg ha egy tutszi elszegényedett, hutu lett belöle. Ezek a jellegzetességek abban az időben kezdtek kikristályosodni, amikor az európai gyarmatosítók az országba érkeztek.

Az első európai, aki 1894-ben eljutott Ruandába, egy G. A. von Götzen nevű német utazó és katonatiszt volt. A gyarmatosító nagyhatalmak már nyolc évvel korábban a berlini konferencián felosztották egymás közt Afrikát: a németeknek juttatták Ruandát, amiről egyetlen ruandait, még a királyt sem értesítettek. A németek később sem foglalkoztak számottevően ásványi anyagokban szegény gyarmatukkal, az első világháború után pedig el is veszítették Belgium javára. ${ }^{350}$

Az 1920-as évektől kezdődően a belga jelenlét sokkal intenzívebb volt a korábbi német gyarmatosítókénál. A belgák saját képükre igyekeztek formálni a ruandai államot, és megreformálták a közigazgatást az adminisztratív hatékonyság jegyében. Ugyanakkor túlértékelve a tutszik társadalmi szerepét, megerősítették a tutszik „kiválasztott” voltát. Csak a tutszik viselhettek hivatalt, a hutu hivatalnokokat módszeresen eltávolították. A hutuk nem tanulhattak tovább, hiszen az felkészülés volt

\footnotetext{
349 „Mindennek a tehén volt a mértéke: a gazdagságnak, a tekintélynek, a hatalomnak. Minél több tehene volt valakinek, annál gazdagabb volt. Minél gazdagabb volt, annál több hatalommal rendelkezett. Legtöbb tehene a királynak volt, az ö csordáit különleges gondoskodás övezte. A nemzeti ünnep fénypontját a királyi emelvény elött évente megtartott tehénseregszemle jelentette. Az uralkodó szeme elött ilyenkor milliónyi tehén vonult el. A felvonulás órákig tartott. A tehenek óriási porfelhőket vertek, $\mathrm{s}$ e porfelhök mérete a monarchia jólétének bizonyítékául szolgált, magát az ünnepséget pedig többszörösen megénekelte a tutsik patetikus költészete.” (Kapuscinski: Ében, Előadás Ruandáról: http://www.forrasfolyoirat.hu/0007/ryszard.html [2012.09.12.])

${ }^{350}$ Kapuscinski, Ryszard (1998): Ében,
} 
az adminisztratív pályára. Ezzel nem csak az 1920-30-as évek, hanem a következő generációs hutuk lehetőségeit is korlátozták.

A tutszik hatalmi monopóliumának „kőbe vésésével” a belgák elvetették a jövő etnikai alapú konfliktusának magjait Ruandában. A húszas-harmincas években széles körben elterjedtek az áltudományos rasszista elméletek a fehér faj felsőbbrendűségéröl és a rasszok eltérő képességeiről, és a belgák Afrikában is ennek megfelelően rendezték be Ruandát: meg voltak győződve róla, hogy a tutszik magasabb rendủek, mint a hutuk, a hutuk a twák fölött állnak, és a ranglétra tetején természetesen a fehér ember található.

Mivel a tutszik külsőleg jobban hasonlítottak a fehér emberekre, a belgák logikusnak találták, hogy képességeikben is közelebb állnak hozzájuk. Alkalmasabbnak vélték őket a vezetésre, így természetesnek tünt, hogy a hutukat és a twákat alá kell rendelni nekik (éppúgy, ahogy a fehér ember is képes vezetni a feketéket). A belgák csak annyit láttak, hogy ennek a viszonylag jól szervezett államnak a vezetője és a körülötte élők nagy része tutszi, így a tutsziknak tulajdonították az egész államszervezet felépítését, és nem vették figyelembe a hutuk rendkívül fontos szerepét Ruanda felépítésében. $^{351}$

A tutszik lelkesen fogadták el a nekik szánt szerepet, hiszen ez egybeesett a saját magukról kialakított képükkel.

Miután a belga gyarmatosítók csak tutsziknak engedélyezték a hivatalviselést, meg kellett állapítani, hogy pontosan ki tutszi és ki nem. A csoporthoz tartozás elvileg öröklött tulajdonság volt, így a családfa alapján lehetett leginkább megállapítani a hovatartozást. Ezt azonban nehézkesnek és időigényesnek találták a belgák, így úgy döntöttek, hogy egyszerübb és hatékonyabb megoldás lesz írásban feljegyezni a hovatartozást már születéskor. Ezt a rendszert a harmincas években vezették be, ekkor az egész lakosság etnikai hovatartozását felmérték, és beleírták az illető személyi igazolványába, amelyet mindenkinek magánál kellett hordania. Így a korábban lehetséges etnikai változtatásokat (ha valaki feljebb lépett a társadalmi ranglétrán, tutszi lett, aki elszegényedett, hutuvá vált) már sokkal nehézkesebben lehetett csak kieszközölni.

Az etnikai csoportok írásbeli rögzítése tovább növelte annak a jelentőségét, hogy ki melyik csoporthoz tartozik. A korábbi ,amorf és rugalmas” kategóriák olyan állandóvá és merevvé váltak, hogy egyes kortárs európai szerzők „kasztként” kezdték emlegetni

\footnotetext{
${ }^{351}$ Des Forges, Alison Liebhafsky (1999): "Leave none to tell the story": Genocide in Rwanda Human Rights Watch
} 
őket. ${ }^{352} \mathrm{Az}$ uralkodó elit egyre jobban „beleélte” magát szerepébe, hangsúlyozta különállóságát és magasabbrendűségét, míg a hutukat fokozatosan összekovácsolta az elnyomottak közti szolidaritás.

Belgium az ötvenes évekig támogatta a tutszik uralmát, de a gyarmatosítás végének közeledtével, valamint a nemzetközi közvélemény (ENSZ) nyomásának hatására elkezdte átszervezni a ruandai közigazgatást és feloldani a tutszik privilegizált helyzetét. A gyarmatosítók az ötvenes évekig szinte teljes egészében a tutszikra támaszkodva kormányozták Ruandát, és váratlanul érte őket, amikor a tutszi értelmiség elkezdte Ruanda függetlenségét követelni. Erre szakítottak a tutszikkal, és az engedékenyebbnek, szolgálatkészebbnek tünő hutukat kezdték támogatni. A taktikaváltás arra is szolgált, hogy elodázza Ruanda függetlenné válását. A korábban mellőzött hutuk álláshoz juthattak az állami szerveknél, járhattak középiskolába. Ezek a kis változások megijesztették a privilégiumaikhoz ragaszkodó tutszikat, de nem elégítették ki a forradalmi változásra vágyó hutukat. A belgák hirtelen pálfordulása csak tovább szította az etnikai feszültségeket.

1959 novemberére rendkívül feszült helyzet alakult ki. Rudahigwa király (aki 1931 óta uralkodott), hirtelen meghalt és utódja Ndahindurwa lett, aki egy konzervatív tutszi csoport befolyása alatt állt. Amikor néhány tutszi váratlanul egy hutu alvezér ellen fordult, és amint az incidens híre elterjedt, országszerte felbőszült hutu földmüvesek támadtak rá tutszi uraikra. Több száz ember meghalt, mielőtt a belgák közbeavatkoztak és helyreállították a viszonylagos rendet. A fellázadt hutu többséget azonban már nem lehetett lecsendesíteni: a monarchia megszünt létezni, a tutszik kasztja elvesztette vezető szerepét. A hatalmat a hutu parasztság vette át.

Ruanda 1962-ben nyerte el függetlenségét, és a hutuk alakították meg az első kormányt élén egy fiatal hutuval, Grégoire Kayibandaval. Az 1959-61-es események mint „hutu forradalom” vonultak be Ruanda történetébe, habár a váltás meglehetősen békésen zajlott le.

A belgák eleinte segítették a hutu hatalomátvételt, remélve, hogy kezükben maradhat az ország. A hutuk inkább elüldözték a tutszi vezetöket, semmint megölték volna őket. Sok tutszi azonban az ellenséges közhangulat miatt kénytelen volt menekülőre fogni: sokan a ritkábban lakott Bugesera régióban telepedtek le (belső menekültek- IDP), de mintegy 10.000 tutszi elhagyta Ruandát. 1961 után ezek a

${ }^{352}$ Ibid, 35.o. 
menekültek sporadikusan támadásokat hajtottak végre Ruanda ellen, amit a hutu vezetők gyakran a Ruandában élő tutszikon bosszultak meg. Ezeket a betöréseket a hutu szolidaritás és öntudat erősítésére is felhasználták.

Ekkoriban vált általánossá, hogy a kormányzat hutu hadserege nem csak a volt tutszi vezetőket, vagy a külföldről támadó tutszi menekülteket esetleg segítő tutszikat támadták meg, hanem általánosságban is intéztek támadásokat a tutszi lakosok ellen. Ezen támadások vezérelve az anyagi haszonszerzés is volt. Aki a támadást végrehajtotta, az a helyi hutu vezető hallgatólagos beleegyezésével eltulajdoníthatta a tutszi földjét, állatait, stb. A korábban elönyt jelentő tutszi megjelölés a személyi igazolványokban 1961 után folyamatos diszkrimináció forrásává vált. A forradalom utáni években jelentősen csökkent a tutszik aránya a ruandai társadalomban, mivel nagyon sokukat megölték (becslések szerint mintegy 20.000 halálos áldozata volt az állandósuló atrocitásoknak) vagy önként elmenekültek az országból (200.000 tutszi menekült el Ruandából ebben az időszakban) ${ }^{353}$, illetve aki csak tudta, igyekezett elintézni átminősítését tutsziból hutuvá. ${ }^{354}$ Az 1960-as években jelent meg és vált egyre elterjedtebbé az Inyenzi (csótány) kifejezés. Ezzel a megnevezéssel illették a külföldre menekült ruandai származású tutszikat, akik rendszeres betöréseket hajtottak végre Ruanda területére. Később már az egész ruandai tutszi népességet Inyenzinek nevezték. ${ }^{355}$ Ryszard Kapuscinski lengyel újságíró így ír a menekültek és ruandaiak viszonyáról: „Éveken át tartanak a határmenti harcok, pogromok, vérfürdők. A tutsi partizánok (a hutuk csak csótányoknak nevezik őket) fölgyújtják a falvakat, irtják a lakosokat, akik viszont, saját hadseregük támogatásával, a tutsikat mészárolják.”

A ruandai első köztársaság vezetője, Kayibanda és a Parmehutu (kormánypárt) eleinte megerősödve került ki a menekültekkel folytatott harcokból, de 1963-tól a párton belüli fokozódó feszültség (a fővárosban és vidéken kemény csatározás folyt a hatalmat jelentő pozíciókért és támogatókért), ${ }^{356}$ országszerte éreztetni kezdte hatását. Ehhez társult a rettegésből fakadó mentális bénultság, amely megakadályozta, hogy a hutuk és tutszik békében éljenek egymás mellett. A hutuk érezték, hogy nem számoltak le tutszi uraikkal végérvényesen, nem irtották ki őket teljesen. Ez a félelem megalapozott volt: a

\footnotetext{
${ }^{353}$ Kuperman, Alan J. (2004): Provoking genocide : a revised history of the Rwandan Patriotic Front, in Journal of genocide research, 6 (1), 63.o.

${ }^{354}$ Des Forges (1999), 37.o.

${ }^{355}$ Chrétien, Jean- Pierre (2003): Afrique des Grands Lacs, 2000 ans d'histoire, Editions Flammarion, Paris, 268.o. ; Lemarchand, René (1970): Rwanda and Burundi, Pall Mall Press, London, 198.o.

${ }^{356}$ Reyntjens, Filip (1985): Pouvoir et droit au Rwanda, Droit Public et Evolution politique, 1916- 1973, Musée Royal de l'Afrique Centrale, Tervuren, Belgique, 473.o.
} 
hutuk uralta Ruandát a „tegnap” elüzött tutszik menekülttáborai vették körül, valamint az országban élő népességnek mintegy 15 százaléka is tutszi volt (ötödik hadoszlop!). A hutuk tehát rettegtek a tutsziktól. De ugyanennyire féltek a tutszik is attól, hogy a határmenti tutszi menekültek betörései miatt a kormány rajtuk áll bosszút. Ez a félelem szintén megalapozott volt. A bosszútól való rettegés miatt a hutu forradalom utáni éveket a két etnikai csoport közötti atrocitások sorozata jellemezte. ${ }^{357}$

1972-ben Burundiban a tutszi vezetés a többségi hutu lakosság ellen népirtást hajtott végre. Ennek hatására Ruandában a tutszik elleni pogromok újabb hulláma kezdődött. A pogromok okozta káoszt kihasználva 1973. július 5-én Juvénal Habyarimana tábornok, védelmi miniszter sikeres puccsot hajtott végre. Ez a dátum tekinthető a második köztársasági időszak kezdetének. Habyarimana gyorsan helyreállította a rendet országszerte, majd a következő két évben megszabadult a Kayibanda-rezsim kulcspozíciókban dolgozó híveitöl (börtönbe juttatta vagy meggyilkoltatta őket). ${ }^{358}$ A második köztársaság igyekezett a nemzeti egységet hangsúlyozni az etnikai széttagoltság helyett, a gazdasági fejlődést helyezte a középpontba. A rezsim eleinte jelentős gazdasági sikereket ért el, azonban ennek jótékony hatása nem jutott el a vidéki parasztság nagy részéhez. ${ }^{359}$ A föváros sokkal dinamikusabban fejlődött, és kialakult a kormányt kiszolgáló elit (umukire), amely szinte kizárólagosan magának tartotta meg a hasznot. ${ }^{360}$

Az 1975-ben alapított MRND (Nemzeti Forradalmi Mozgalom a Fejlődésért) teljes egészében összefonódott az állam szerveivel ${ }^{361}$, egypártrendszer alakult ki. Egyre nagyobb hatalom összpontosult Habyarimana elnök kezében. Bár az etnikai hovatartozás kérdését a második köztársaság kerülte, az adminisztráció mintegy 8590\%-a a hutuk kezében volt, ${ }^{362}$ mégpedig az északról származó hutukat részesítették előnyben Habyarimana északi származása miatt. ${ }^{363}$

Ezzel párhuzamosan a ruandai határ közelében található ugandai menekülttáborokban új politikai mozgalom kezdett formálódni. (1959 óta már több mint

\footnotetext{
${ }^{357}$ Prunier (1995), 60.o.

${ }^{358}$ Munyarugerero, François- Xavier (2003): Réseaux, pouvoirs, oppositions, La compétition politique au Rwanda Editions L'harmattan, Paris, 147.o.

359 Bezy, Fernand (1990) Rwanda 1962- 1989, bilan socio- économique d'un régime, université catholique de Louvain, Institut d'Etudes du Développement, Louvain, 28.o.

${ }^{360}$ De Lame, Danielle (1996) Une colline entre mille ou le calme avant la tempête, Transformations et blocages du Rwanda rural, Musée Royal de l'Afrique centrale, Tervuren, Belgique, 182.o.

${ }^{361}$ Guichaoua, André (1995), Les crises politiques au Burundi et au Rwanda (1993-1994), Université des Sciences et Technologies de Lille/Karthala, Paris, 145.o.

362 Chrétien, 2003, 271.o.

${ }^{363}$ Chrétien, 2003, 269.o.
} 
600.000 ember menekült el Ruandából) ${ }^{364}$ A Ruandai Hazafias Front (RPF- ezt a nevet 1988-ban vették fel) erői Yoweri Museveni (későbbi ugandai elnök) 1986-os hatalomátvételét is segítették. ${ }^{365} \mathrm{Az}$ RPF célja az volt, hogy segítse a menekültek hazatérését Ruandába. 1986-ban a ruandai hatóságok azonban kijelentették, hogy Ruanda túl sürün lakottá vált, és a menekültek hazatérése lehetetlen. Ez a kijelentés tovább tüzelte a Ruandából elmenekülteket.

Mintegy tíz évvel a hatalomátvétel után a Habyarimana-rezsim destabilizálódni kezdett: szétzilálták a hatalmi pozíciókért folytatott egyre keményebb harcok. Az 1980as évek végére a Habyarimana-rezsim lassan gazdaságilag is kifulladt. Ennek oka egyrészt, hogy a gazdasági hasznot az elit nem forgatta vissza a ruandai társadalomba, másrészt a világpiacon csökkenni kezdett Ruanda egyik legfőbb exportcikkének, a kávénak az árfolyama. ${ }^{366}$

Időközben nyugati nyomásra Habyarimana bizonyos látszatreformokat hajtott végre, amelyek a többpártrendszer irányába való elmozdulást sejtették. Ruandában a „demokratikus átalakulás” eredményeképpen ellenzéki és kormányközeli pártok sora alakult. $^{367}$

A demokratikus átmenet nehézkes folyamatát tovább bonyolította, hogy az RPF 1990. október elsején offenzívát indított mintegy hétezer harcossal, akikhez Ruandában további háromezer civil csatlakozott. ${ }^{368} \mathrm{Az}$ RPF erőit egy hét múlva a ruandai kormány hadseregének katonái, a Ruandai Haderő (FAR) francia ${ }^{369}$ segítséggel feltartóztatta.

\subsection{Elökészületek}

1990 után állandósultak a harcok az RPF és a kormányerők között Ruandában: a ruandai hadsereg létszáma az 1990-es 5200 főről 1993-ra 40000 főre emelkedett. A belső menekültek száma is folyamatosan növekedett (1993 áprilisában egymillió belső menekült állomásozott Kigali környékén). ${ }^{370}$ A kormányhoz közel álló és az ellenzéki

\footnotetext{
${ }^{364}$ Reyntjens, Filip (1994): L’Afrique des grands- lacs en crise, Rwanda, Burundi : 1988- 1994, Editions Karthala, Paris, 25.o.

365 Prunier (1999), 192.o.

${ }^{366}$ Viret, Emmanuel (2010): Chronologie du Rwanda (1867- 1994), Encyclopédie en ligne des violences de masse http://www.massviolence.org/Chronologie-du-Rwanda-1867-1994 [2012. 08.11.]

367 Prunier (1995), 121-126.o.: MDR: mérsékelt köztársasági párt, PSD: szociáldemokrata párt, PL: liberális párt, PDC: kereszténydemokrata párt

${ }^{368}$ Kuperman (2004), 70.o.

${ }^{369}$ A hagyományos belga katonai segítségnyújtást 1991 után felváltotta a francia szerepvállalás, amely az anglofon afrikai térnyerést volt hivatott ellensúlyozni, valamint gazdasági hasznokat remélt az afrikai országokkal való együttmüködéstöl.

${ }^{370}$ Guichaoua (1995), 511.o.
} 
politikai pártok mindegyike igyekezett megalakítani a maga fiatal, militáns szárnyát (Impuzamugambi, Interahamwe, Inkuba, Abakombozi), akik újabb támogatókat gyüjthettek vagy szükség esetén erődemonstrációra is alkalmasak voltak. Ezek a szervezetek sokszor önálló életre keltek (többé-kevésbé az „,anyapárt” támogatásával): mindennapossá váltak a kényszerbesorozások és az erőszakos cselekmények. Az évek óta tartó gazdasági és politikai válság kiélezte a társadalmi feszültségeket.

A menekült tutszikat képviselő RPF-et az egész tutszi etnikai csoporttal azonosították a kormányerők, és a médián keresztül olyan bosszúszomjas képet festettek az RPF-ről, mint akik az egész afrikai Nagy Tavak régiót tutszi uralom alá akarják hajtani. ${ }^{371}$ A tutsziellenes propaganda médiuma volt többek között a Kangura címü újság, amely 1990-ben megjelentette a Hutu Tízparancsolatot, amely egyértelmü felhívás a tutszik kirekesztésére a társadalomból. ${ }^{372}$ Míg az írott sajtó főleg a városi elitet célozta meg, az 1993. július 8-án induló, később hírhedtté vált Radio Télévision Libre Mille Collines (RTLM) a rasszista propagandát ügyesen ötvözte a legújabb zenei irányzatokkal. A rádió sztárjai nemcsak a tutszikat ostorozták, hanem az RPF-fel tárgyalóasztalhoz ülő hutukat is. Gyakran leadták a Nanga Abahutu című számot is,

\footnotetext{
${ }^{371}$ Chrétien (1995) 142- 150.0., 162-174.o.

${ }^{372}$ Chrétien (1995), 38-40.o.
}

1. Minden hutunak tudnia kell, hogy a tutszi nő, legyen bárhol, a tutszi ügyért dolgozik. Éppen ezért minden hutu, aki tutszi nőt vesz el, tutszi ágyast tart, vagy tutszi titkárnőt vagy alkalmazottat vesz fel, áruló.

2. Minden hutunak tudnia kell, hogy a hutu lányok sokkal értékesebbek és öntudatosabbak, mint feleségek és anyák. Hát nem szeretetre méltóak? Csodálatos titkárnők és becsületesebbek!

3. Hutu nők, figyeljetek, hogy férjetek, fivéretek, fiatok világosan lásson.

4. Minden hutu legyen tisztában azzal, hogy a tutszik tisztességtelenek az üzleti életben. Egyetlen céljuk az etnikai felsőbbség. Ezt már tapasztaltuk és megtanultuk. Minden hutu áruló, aki üzleti ügyben tutszival szövetkezik, tutszi vállalkozásba fekteti a saját vagy az állami pénzt, kölcsönkér vagy kölcsönt ad egy tutszinak, kedvez egy tutszinak (importengedély, banki kölcsön, építési telek, piac...)

5. A stratégiai állásokat mint politikai pozíciók, közigazgatás, közgazdaságtan, katonaság és közbiztonság csak hutuk foglalhatják el.

6. Az oktatási rendszerben hutu többségnek kell lennie (diákok, tudósok, tanárok)

7. A ruandai hadseregben csak hutuk szolgálhatnak. Az 1990 októberi háború bizonyította ezt. Egy katona sem vehet el tutszi nőt.

8. A hutuknak nem szabad megsajnálniuk a tutszikat.

9. A hutuknak, legyenek bárhol, mindig egységesnek kell lenniük, szolidárisnak, és gondolniuk kell hutu testvéreik sorsára. A Ruandában és Ruandán kívül élő hutuknak folyamatosan barátokat és szövetségeseket kell keresniük a hutu ügyhöz, kezdve bantu testvéreikkel. A hutuknak ellent kell mondani a tutszi propagandának. A hutunak keményen és éberen ellen kell állni a közös ellenségnek: a tutsziknak.

10. Az 1959-es társadalmi forradalom, az 1961-es népszavazás és a hutu ideológia tanítása minden hutunak kötelező. Minden hutunek terjesztenie kell az igét, akár merre jár. Ha egy hutu üldözi testvérét ezen ideológia tanításáért és terjesztéséért, az a hutu áruló. 
amelynek jelentése (Utálom ezeket a hutukat) célzás a népüket „eláruló” hutukra, akik hajlandóak tárgyalni az RPF-fel. ${ }^{373}$

Egyes szélsőségesek még ennél is tovább mentek: azt állították, hogy a tutszik a hutuk létét veszélyeztetik, mivel uralmukat a többség fölött nem tudják másként biztosítani, csak ha nagy számban pusztítanak el hutukat. 1990-ben a Kangura c. újság már azzal vádolta a tutszikat, hogy olyan háború előkészítésén munkálkodnak, amely nem hagyna túlélőket. ${ }^{374}$ A Kangura arról is hírt adott, hogy az elfogott RPF-katonák azt mondták, ,azért jöttek, hogy megtisztítsák az országot a hutu piszoktól”. 375

Az RPF gerillaakcióival nem tudott egyértelmü katonai sikereket aratni, így tárgyalóasztalhoz kényszerült. Időközben a nyugati kormányok az RPF-fel való béketárgyalásokhoz, valamint a demokratizálási folyamat sikeréhez kötötték a segélyezést. Ezért a ruandai kormány is tárgyalni volt kénytelen.

A feszült légkör mellett a béketárgyalások nem haladtak megfelelöen. A kormányerők, RPF-erők és a demokratikus ellenzék közötti békét ígérő arushai ${ }^{376}$ megállapodás hosszas tárgyalások után Habyarimana csökönyös ellenállásától függött. 1993 nyarán azonban már legfontosabb támogatója, Franciaország is kezdte elveszteni türelmét és felszólította az elnököt, hogy a megállapodást alá kell írnia, különben megvonják tőle az anyagi támogatást. 1993. július végén Franciaország a Világbankkal karöltve közölte Habyarimanával, hogy ha augusztus 9-ig nem sikerül megegyezni, akkor felfüggesztik a kormány anyagi támogatását. Mivel más anyagi segítség nem állt Habyarimana rendelkezésére, 1993. augusztus 4-én megszületett az arushai egyezmény, amely számos részterületet ölelt fel: megalapozta a jogállamiságot, az átmeneti intézményeket, amelyek a következő választásokig vezetik az országot, rendezte a menekültek repatriálást, a belső menekültek újratelepítését, és a két hadsereg (RPF, FAR) leszerelését, összeolvasztását nemzeti haderővé. A végrehajtásra világos időkorlátokat szabott meg az egyezmény.

\footnotetext{
${ }^{373}$ Chrétien (1995), 341.o.

${ }^{374}$ A népirtás kezdetére ezek a rémhírek odáig jutottak, hogy a tutszik tömegsírokat ásnak, amelyekbe a hutuk holttestét akarják eltemetni, ha eljön az idő. Az RPF-erők valóban ástak árkokat a pozíciójuk védelme érdekében, talán ez adhatott valamiféle táptalajt ezeknek a valóságtól elrugaszkodott elképzeléseknek. Egyesek azt terjesztették, hogy a tutszik a kunyhójuk padlójába is lyukat ástak, mert oda akarják rejteni a hutu holttesteket.

${ }^{375}$ Solidarité Internationale pour les Réfugiés Rwandais, Le Non-Dit sur les Massacres au Rwanda, vol. 2 , January 1995, p. 11 and vol. 3, July 1995, pp.124-37; Chrétien et al., Rwanda, Les médias, 266.o, 176.o.

${ }^{376}$ Arusha Tanzánia fővárosa
} 
$\mathrm{Az}$ átmeneti kormányban helyet kaptak a kormányerök, az RPF erői és a demokratikus ellenzéki pártok is. Elvileg Habyarimana maradt az elnök, de döntéshozói hatalma nagy részét delegálnia kellett volna egy ún. Minisztertanácsnak.

A megfigyelők és a ruandaiak kezdettől fogva tisztában voltak az arushai egyezmények törékenységével. Nyilvánvalónak tünt, hogy Habyarimana nem nagyon akarja kiadni kezéből a hatalmat, és minél tovább húzódik az egyezmény implementációja, annál valószínűbb, hogy az egész általa felépített struktúra összedől, és újra kitör a háború. Maguk az aláíró felek is meglehetősen szkeptikusan álltak az egyezmény betartásához. Az RPF például folytatta a toborzást. A Habyarimanához közel álló Félicien Kabuga hatalmas mennyiségü machetét importált (1993 januárjától 1994 márciusáig összesen 581.000 kilogrammot). Ha feltételezzük, hogy minden machete körülbelül egy kilót nyom, akkor a rendelt mennyiség alkalmas volt arra, hogy minden harmadik hutu felnőtt férfit felfegyverezzenek Ruandában. (A ruandai genocídium utólag hírhedtté vált arról, hogy az emberölések nagy részét bozótvágó késsel, azaz machetével hajtották végre)

A törékeny arushai egyezményt még nyugodt regionális körülmények között is nehéz lett volna betartani, de a burundi elnök meggyilkolása után gyakorlatilag lehetetlenné vált. Miután Burundiban hosszú évtizedekig a tutszi kisebbség uralkodott a hutu többség fölött, Melchior Ndadaye mérsékelt hutu elnök hivatalba lépése hatalmas lehetőségnek tünt nem csak Burundi, hanem Ruanda hutu lakóinak szemében is. A józan Ndadaye a két etnikai csoport békés egymás mellett élésének jelképeként az ellenzéki pártból nevezett ki tutszi miniszterelnököt maga mellé. Amikor négy hónappal később tutszi szélsőségesek meggyilkolták, erőszakhullám vette kezdetét Burundiban. Eleinte hutuk álltak bosszút az útjukba kerülő tutszikon, később a tutszi hadsereg bosszúhadjárata kezdődött el.

Ndadaye meggyilkolása és a rákövetkező bosszúhadjáratok azonnal és drámai mértékben rontották a kilátásokat a ruandai békés megoldásra. A mérsékeltek, akik hittek a békés burundi átmenetben, és a hutuk és tutszik békés egymás mellett élésében, egyre nehezebben tudtak optimistán tekinteni arra, hogy az RPF-et békésen sikerülne integrálni a ruandai kormányba. A hutuk úgy érezték, hogy a tutszik valóban nem riadnak vissza az erőszak alkalmazásától, ha szükséges ahhoz, hogy elérjék céljukat, azaz az egész Nagy Tavak régió urai legyenek. Ahogy egy politikai vezető fogalmazott a genocídium ideje alatt: „Kinek nem nyitotta fel a szemét az, ami Burundiban történt? 
[...] megválasztották Ndadaye elnököt, aki tényleg azt akarta, hogy a hutuk és tutszik békében együtt éljenek, de mindenki tudja mit tettek vele [...]”377

1994 április elejére az erőszakra való felhívás általánossá vált, sokan egy közelgő katasztrófát emlegettek, és közben tovább csúszott az arushai egyezmény életbe lépése. Mindkét oldal fegyverkezett és a folyamatosan képezte ki az újonnan besorozottakat. A lakosság attól félt, hogy az UNAMIR (United Nations Assistance Mission in Rwanda, akik az arushai egyezmény betartását felügyelő ENSZ-békefenntartók) és más külföldi szereplők (civil szervezetek, megfigyelők, nagykövetségek) a bizonytalanság hatására kivonulnak Ruandából és sorsára hagyják, lemondva az arushai egyezmény implementációjáról.

1994. április 6-án Habyarimana elnök egy dar-es-salaami csúcstalálkozóról tartott hazafelé Kigaliba, amikor a ruandai fővárosban leszálláshoz készülődő gépét ismeretlen támadók lelőtték. A repülőgép-szerencsétlenségben életét vesztette a gép minden utasa, többek között Burundi akkor elnöke, Cyprien Ntaryamira is.

Máig kérdéses, hogy Habyarimana elnök halála kinek állt leginkább érdekében. A legvalószínűbb, hogy saját radikálisabb követői végeztek vele, mert az arushai egyezmény életbe lépésével hatalmuk jelentősen csökkent volna és az elnök a külföldi nyomás hatására a halála előtti időszakban elgondolkodott azon, hogy a továbbiakban is érdemes-e szabotálnia az egyezmény végrehajtását.

Az a tény, hogy az elnöki gárda a gép lelövése után néhány órával már szervezetten elkezdte a főváros „megtisztítását” a tutsziktól (úttorlaszokat állítottak fel és ezeknél az ellenőrző pontoknál már kivégezték a tutszikat) szintén arra utal, hogy Habyarimana meggyilkolását saját szélsőségesei tervezték meg.

\subsection{A népirtás}

Habyarimana halála után az ideiglenes kormány elnöke névleg Théodore Sindikubwabo lett, gyakorlatilag azonban Théoneste Bagosora ezredes ragadta magához a hatalmat az országban 1994 áprilisától júliusáig. Az 1941-es születésű Bagosora egész karrierje a hadsereghez kötődött. Fokozatosan egyre magasabb rangra emelkedését a többpártrendszer bevezetése és a hadsereg átalakítása megszakította. Bagosora a FAR föparancsnoka akart lenni, de „,be kellett érnie” azzal, hogy kabinetfőnök lett a védelmi minisztériumban. Habyarimana egyik legfontosabb emberének számított, sőt az elnök

${ }^{377}$ Chrétien et al., Rwanda, Les médias, p. 294 
tartott is tőle önálló elképzelései és vezető természete miatt. Habyarimana halála után kihasználta a keletkezett hatalmi ürt és átvette az irányítást. ${ }^{378}$

A népirtás idején Bagosora közvetlen rádiókapcsolatban állt a katonaság prominens alakjaival és a fontosabb politikai vezetőkkel Ruanda-szerte. Ö döntött többek között a Nemzeti Bank átutalásairól és fegyvervásárlásokról, valamint az ő kezében futottak össze a népirtás szervezésének szálai. ${ }^{379}$

Bagosora nem értett egyet az arushai egyezményekkel, olyannyira, hogy mikor 1993-ban felállt a tárgyalóasztaltól, kijelentette, hogy visszatér Ruandába „elökészíteni az apokalipszist”. Az 1994 áprilisát megelőző hónapokban többször is nyilvánosan kijelentette, hogy a ruandai háborúra az lenne a megoldás, ha a ruandai tutszikat kiirtanák. $^{380}$

Miután április elején Bagosora és klikkje magához ragadta a hatalmat, fokozatosan kibontakozott a népirtás. Bagosora kettős játékot játszott. Felszólította a lakosságot, hogy álljanak ellen mindenféle etnikai töltetü uszításnak és erőszaknak, és bejelentette, hogy az arushai egyezmények elöírásait minél elöbb át kell ültetni a gyakorlatba (holott előtte hónapokig a szabotálásukon dolgozott). Arra kérte a fegyveres alakulatokat, hogy tegyenek meg minden a rend helyreállítása érdekében.

A valóságban mindennek éppen az ellenkezője zajlott: április 6-án és 7-én a fóvárosban az ellenzéki politikusokkal és általában a liberálisokkal végeztek a halálosztagok. Agathe Uwilingiyimana mérsékelt politikusként ismert miniszterelnökasszonyt az életét védő belga békefenntartókkal együtt meggyilkolták. Ugyanerre a sorsra jutott az Alkotmánybíróság elnöke, Joseph Karavuganda. Faustin Twagiramungu, akinek az arushai egyezmény alapján Uwilingiyimana helyére kellett volna lépnie, szerencsésen elmenekült az országból, az UNAMIR-erők evakuálták.

A tutszi lakosok ellen irányuló genocídium április 7-én kezdődött Kigaliban, majd a hutu szélsőségesekkel szimpatizáló főbb prefektúrákban (Gisenyi, Ruhengeri). Április 9-én az erőszak átterjedt Byumba, Cyangugu, Gikongoro, Kibungo és Kibuye prefektúrákra, Gitarama és Butare csak április 14-15. után került sorra. ${ }^{381}$

Az emberölésekre összességében az volt a jellemző, hogy bizonyos célpontok prioritást élveztek. Miután a kiemelt áldozatokkal végeztek, sorra kerültek az

\footnotetext{
${ }^{378}$ Viret (2010)

379 Ibid.

${ }^{380}$ TPIR, ICTR-96-7-I, 1999: 20-22

${ }^{381}$ Strauss, Scott (2006): The Order of Genocide, Race, Power and War in Rwanda 50/256.o. Ithaca and London: Cornell University Press
} 
„átlagemberek”. A gyilkosok eleinte kis csapatokban léptek akcióba, és áldozataikat otthonukban, az utcán, a sebtében emelt úttorlaszoknál ölték meg. Később azonban igyekeztek gyorsabban, több emberrel végezni. Április 11-én a hatóságok elrendelték, hogy a tutszi állampolgárok különböző közösségi helyeken gyülekezzenek: stadionokban, iskolákban, templomokban, kórházakban, majd megölték az összeterelt embereket. A „leghalálosabb” időszak az április 11-től május 1-ig tartott. ${ }^{382}$

A népirtás elkövetőit a szemtanúk legtöbbször úgy írták le, mint egyszerü munkásembereket. Azaz az emberölésekre az elkövetők úgy tekintettek, mint a hivatalnok az aznap elvégzendő munkára, vagy a farmer a földművelésre. Minden este dolguk végeztével a gyilkosok összegyültek, és megünnepelték az aznap elvégzett feladatot. Másnap pedig visszatértek, hogy folytassák a „munkát”. 383

A „munka” természetesen nem haladhatott volna olyan elképesztő ütemben, ahogy haladt, ha nem szervezett mederben zajlott volna. A népirtás aktívan részt vettek egyrészt a hadsereg és a rendőrség, másodsorban a politikai pártok és milíciák, harmadrészt pedig az állami közigazgatás emberei. Ez a három tényező, valamint a ruandaiak hagyományos engedelmessége a föhatalom iránt döntő szerepet játszott abban, hogy mintegy száz nap leforgása alatt több százezer embert sikerült kiirtani.

Ruanda népirtó szándékú vezetői hónapok óta készültek erre a fordulatra, és alaposan előkészítették. A népirtást szolgálta a Bagosora által 1993-ban meghirdetett önvédelmi program, amelynek keretében fegyvereket osztottak szét a férfi lakosság körében, valamint a helyi rendőrség megtanította a lőfegyverek használatát, és bevonta a lakosságot a járörözésbe is. A hegyekben általában korábban vezető beosztású, a népirtás idején már nyugdíjas katonatisztek segítettek az elkövetőket „hadrendbe állítani”. A szemtanúk beszámoltak róla, hogy az elkövetők gyakran egy bizonyos előzetes lista alapján dolgoztak. ${ }^{384}$ Roméo Dallaire 1994. január 11-én küldött táviratában ${ }^{385}$ beszámol egy magas rangú informátor értesüléseiről (később kiderült, hogy az informátor Twagiramungu volt). Ebben a táviratban az informátor már említést tesz arról, hogy főnökei arra kérték, állítson össze egy listát Kigali minden tutszi lakosáról. Ezzel párhuzamosan az Interahamwe mintegy 1700 embernek tartott háromhetes hadi kiképzést ruandai katonai táborokban. Az informátor véleménye

\footnotetext{
382 Viret (2010)

${ }^{383}$ Des Forges (1999), 162.o.

${ }^{384}$ Ibid, 158-159.o.

${ }^{385}$ Report of the Independent Inquiry into the actions of the United Nations during the 1994 genocide in Rwanda, S/1999/1257, 10.o.
} 
szerint negyven ilyen kiképzett ember mintegy ezer tutszival tudna végezni húsz perc alatt. 1994. február 20-án egy magasrangú katonatiszt rokonának, Jean Birara bankárnak egy 1500 névből álló „,halállistát” mutatott. ${ }^{386}$ Ilyen listák tehát léteztek, és létezésükről kormánykörökben már április előtt tudtak.

Az elkövetők széles körével kapcsolatban meg kell jegyezni, hogy főleg vidéken a politikai pártok, és azok ifjúsági szárnyai saját őrjáratokat szerveztek és maguk kezdték meg a gyilkolási hullámot, ha a helyi közigazgatás vonakodott megtenni az első lépést. Április 6-án ezek a milíciák még csak kétezer emberrel rendelkeztek, azonban a mészárlások alatt folyamatosan toboroztak, és számuk gyorsan húsz-harmincezerre nőtt. ${ }^{387}$ Sok hutut kényszerítettek, hogy csatlakozzon, és sokan önszántukból vettek részt az öldöklésben. Nehéz megbecsülni, hogy pontosan hány elkövetővel számolhatunk. Egy RPF-szóvivő eleinte 2000 felelősről beszélt, majd a bíróságok ezt 10.000 före emelték, később a politikai vezetők 30.000-re. 1998 közepén már 135.000 ember volt börtönben országszerte, nagyrészt a genocídiummal összefüggő büncselekmények miatt.

$\mathrm{Az}$ áldozatok számának meghatározását az nehezíti, hogy a népirtással párhuzamosan háború is folyt az RPF és a kormányerők között. Így az eleinte megjelenő becslések 800.000 halálos áldozatának nem mindegyike a népirtás miatt halt meg. Gérard Prunier becslése ${ }^{388}$ szerint mintegy 130.000 tutszi volt még életben 1994 júliusában Ruandában, ez a számadat nem vette figyelembe a Zairéba vagy Tanzániába menekülő 20.000 tutszit. Ha így összesen 150.000 túlélővel számolunk, és áprilisban még mintegy 657.000 tutszi élt Ruandában, akkor azt mondhatjuk, hogy a regisztrált tutszi lakosság 77 százaléka elpusztult. A népirtás mintegy 500.000 tutszi és 10.000 és 30.000 közötti hutu áldozatot szedett. ${ }^{389}$

\subsection{A népirtás következményei}

A népirtás végeztével tömeges exodus indult meg Ruandából: 1994 júliusaugusztusában mintegy kétmillió ember hagyta el az országot. Ugyanakkor az ország határain belül is kezelhetetlen méreteket öltött a menekültáradat: 1994 őszén mintegy

\footnotetext{
${ }^{386}$ Marie-France Cros (1994): Jean Birara: 'The Belgians and French Could Have Stopped the Killing,' La Libre Belgique, Foreign Broadcast Information Service (FBIS), Central Africa, May 25, 1994.

${ }^{387}$ Viret (2010)

${ }^{388}$ Prunier (1995), 265.o.

${ }^{389}$ Des Forges (1999), 17.o.
} 
1,8 millió belső menekült (internally displaced person) volt Ruandában. Ez azt jelenti, hogy a kb. hétmilliós összlakosság több mint fele elmenekült lakhelyéről.

A hatalmas menekültáradatnak több oka is volt: egyrészt a genocídiumot megelőző években az ország lakossága évekig hallgatta azt a propagandát, mely szerint a tutszik végső célja a hutuk elpusztítása és a hatalom átvétele Ruandában. Úgy tünt, ennek megteremtődtek a feltételei, amikor az RPF átvette az ellenőrzést az ország egész területe felett. Százezrek menekültek az RPF elöl. Sokan, akik maradtak volna, nem tehették meg. A népirtás elkövetői számos esetben szervezetten, fegyverrel ürítették ki a falvakat, városokat, és terelték át az embereket az országhatáron túlra.

Az RPF bosszúhadjáratától való félelem sem volt alaptalan. Az RPF szigorú toborzási színvonala jelentősen visszaesett a genocídiumot megelőző években, hónapokban, mivel egyre több katonára volt szükségük a harcok intenzitásának fokozódása miatt. Az eredeti, ugandai „kemény mag” jelentősen felhígult, főleg ruandai tutszi elemekkel, akiknek családtagjai estek áldozatul a vérontásnak. Miután az RPF elfoglalta Ruandát, katonái -gyakran a felettesek parancsa ellenére is- bosszúhadjáratot folytattak a népirtás elkövetői, de gyakran válogatás nélkül a civil hutu lakosság ellen.

Hat hónappal a népirtás vége után az újonnan toborzott RPF-tagok még mindig nem kapták meg első zsoldjukat, így sokan pénzért felajánlották szolgálataikat a fizető civileknek. Az ügyfelek vagy tulajdonuk védelmére, vagy valakinek a meggyilkolására vették bérbe a katonákat. A közbiztonság drámaian rossz volt az országban. Számos „bandita” is tevékenykedett mind a fővárosban, mind vidéken: ha fegyverhez jutottak, nem riadtak vissza a fosztogatástól, emberöléstől sem.

Közben az 1959-61-es hutu forradalom miatt Burundiba és más környező országokba menekült tutszik egyre nagyobb számban szivárogtak vissza Ruandába. Míg júliusban még csak százezren voltak, augusztusban már kétszázezren, novemberben pedig már kb. négyszázezren. A visszatérők elfoglalták az üresen álló házakat, telkeket, de az is gyakori volt, hogy ha nem volt hova menniük, egyszerüen felbéreltek egy fegyverest, hogy tegye el láb alól azt az embert, akinek a házára szükségük volt. Ennél is egyszerübb módszer volt feljelenteni az illetőt, hogy Interahamwe-tag volt, és aktívan részt vett a népirtásban.

Miután Ruanda viszonylag kis alapterületü és a rendelkezésre álló erőforrások meglehetősen szűkösek, néhány hónap eltelte után a ruandai vezetés és a „házfoglalók” egyre kevésbé szerették volna, ha a hutu menekültek visszatérnek eredeti lakhelyükre. Ebből a szempontból az RPF vezetésének számos tagja hasznosnak is találta a 
bosszúszomjas RPF-katonák magánakcióit, hiszen egyrészt elveszik a hutuk kedvét a hazatelepüléstől, másrészt a megmaradt hutu többséggel megértetik, hogy alá kell rendelődniük az új tutszi vezetésnek.

A nagy kérdés természetesen az volt a nemzetközi közösség számára, hogy az RPF vezetése részt vesz-e a bosszúhadjáratok szervezésében, csak szemet huny fölötte, vagy nem ért egyet katonái viselkedésével, de nincs uralma felettük. Az RPF színleg elítélte az atrocitásokat, és igyekezett katonai bíróságok felállításával gyorsan felelősségre vonni az elkövetöket:1994 januárjáig mintegy hatszáz RPF katona került börtönbe. Összességében azonban vagy nem tudta, vagy nem akarta (ez a valószínübb) megakadályozni a tömeges erőszakot: a népirtás után elkövetett emberölések áldozatainak számát nagyon nehéz utólag megítélni, de 1994 júliusa és 1995 áprilisa között valószínűleg meghaladta a 100.000 föt. ${ }^{390}$

$\mathrm{Az}$ áldozatok holttestét ebben a zavaros időszakban nem volt nehéz eltüntetni Ruandában: sokszor éppen a népirtás kapcsán keletkezett holttestekkel keverték össze az új áldozatokat.

Egy másik súlyos kérdés, amellyel az új vezetésnek szembe kellett néznie, a népirtás elkövetőinek felelősségre vonása. Ahogy Paul Kagame (az RPF vezetője, ma Ruanda elnöke) fogalmazott: „Nem lehet tartós megbékélés, amíg a ruandai népirtás felelőseit nem állítják bíróság elé.” ${ }^{391} \mathrm{Ez}$ azonban a genocídium utáni Ruandában nagyon nehéz feladatnak bizonyult: a bírósági rendszer gyakorlatilag megszünt létezni, a börtönök túlterheltek voltak, nem jutott megfelelő mennyiségü élelem a foglyoknak. A tanúk élete is veszélyben forgott: korábbi Interahamwe-tagok támadásaitól kellett tartaniuk (még Zairéból is be-betörtek Ruanda területére, hogy elnémítsanak egy-egy fontos szemtanút, akiről gyanították, hogy tanúskodhat ellenük).

A túlélők is megosztottak voltak: a tutszi visszatérők a túlélőket a népirtók kollaboránsainak nevezték. A mérsékelt hutu családok nem számítottak ,igazi” áldozatnak a tutszik szemében: a tutszi özvegyek a túlélők egyesületeiben nem voltak hajlandóak hutu özvegyek mellé ülni. ${ }^{392}$

Ilyen körülmények között kellett megtalálni az együttélés módját, felépíteni a megbékélés és a bizalom légkörét. Ez nemcsak az RPF által elkövetett tömeges emberi

\footnotetext{
${ }^{390}$ Stephen W. Smith oknyomozó újságíró becslése a Libération c. újság 1996 februári számában. In: London Review of Books, Vol. 33. No. 6. 17 March 2011, Stephen W. Smith: Rwanda in Six Scenes. Smith utólag Gitarama megyében végzett számításokat az áldozatokról, és eredményeit extrapolálva Ruanda egész területére 150.000-re módosította ezt a számot

${ }^{391}$ Prunier (1995), 343.o.

${ }^{392}$ Ibid, 359.o.
} 
jogi jogsértések miatt volt nehéz, hanem azért is, mert a társadalom szinte minden eleme rettegett: nem volt világos, hogy a népirtásban milyen mértékü bünrészesség von maga után bírósági eljárást.

Az elkövetők nagy száma miatt a hagyományos bírósági úton történő felelősségre vonáshoz nem álltak rendelkezésre a szükséges feltételek Ruandában. A népirtás után hivatalba lépő kormány az „egység és megbékélés” politikáját követve 2001-ben döntött a gacaca bíróságok felállításáról. A gacaca bíróságok eredetileg kisebb falusi nézeteltérések (lopások, földviták, házassági problémák) rendezésére szolgáltak: az adott település öregjei összegyültek és az áldozatokkal együtt megvitatva a kérdéses ügyet, az egész falu előtt szolgáltattak igazságot. Az, hogy a népirtás felelőseit helyi szinten, egy kisebb közösségben az ott élők saját maguk között vonták felelősségre, éppen a megbékélést hivatott elösegíteni. ${ }^{393}$ Másrészt a népirtás után az elkövetők évekig sínylödtek börtönben, mert nem volt kapacitás az ügyük megtárgyalására. A gacaca bíróságok (országszerte több mint 12.000 bíróság) rövid idő alatt (gyakorlatilag 2005-ben kezdték meg és 2012-ben fejezték be a tárgyalásokat) mintegy 1,2 millió ügyet tárgyaltak, amelyek mintegy 65 százalékában született elmarasztaló ítélet. ${ }^{394}$ A súlyosabb eseteket átadták az ENSZ Ruandával foglalkozó Nemzetközi Büntető Törvényszékének (ICTR), amely 2012 májusáig a 93 vádlottból 83 ügyét tárgyalta meg. Összesen 52 elsőfokú ítélet született 72 vádlott ügyében. ${ }^{395}$ Az ICTR tevékenységét valószínüleg 2012 végéig befejezi.

Bár a gacaca bíróságok megítélése ellentmondásos (a megfelelő jogi ismeretek, jogi képviselet hiánya erősen befolyásolta a bíróságok működését, vesztegetéssel befolyásolt és aránytalan ítéletek is születtek), sok ruandai úgy ítéli meg, hogy müködésük hozzájárult a múlt sebeinek begyógyításához. ${ }^{396}$

A népirtás egyik legfontosabb hosszú távú következménye, hogy a hatalmat magához ragadta a tutszik vezette RPF, és 1994 óta nem engedi ki a kezéből. Paul Kagame korábbi RPF-vezető meglehetősen autoriter rezsimet épített ki, ahol az

\footnotetext{
${ }^{393}$ Vannak azonban éppen az ítélkezéshez kapcsolódó, a megbékélés ellen ható folyamatok is: számos vádlót gyilkoltak meg bosszúból a tárgyalások után, ráadásul sokakat még a perek előtt megfenyegettek a vádlottak rokonai, barátai. Emiatt sokszor a túlélők és rokonaik is bosszút forraltak, az elmúlt években több ilyen támadásról is beszámoltak a helyi jogvédők.

394 A Human Rights Watch 2011-ben publikált jelentése ("Justice Compromised: The Legacy of Rwanda's Community-Based Gacaca Courts) alapján

${ }^{395}$ Assessments of the President and the Prosecutor of the International Criminal Tribunal for Rwanda on the implementation of the completion strategy of the Tribunal http://www.unictr.org/Portals /0/English/FactSheets/Completion_St/S-2012-349.pdf 22 May, 2012

396 BBC World News, Africa: Rwanda 'gacaca' genocide courts finish work, 18 June 2012 http://www.bbc.co.uk/news/world-africa-18490348, [2012.09.04.]
} 
ellenzéki hangokat gyorsan elnémítják. Az első népirtás utáni választások 2003 augusztusában zajlottak, amelynek eredményeként Paul Kagamét hét évre kinevezték Ruanda elnökévé. A helyzet kísértetiesen emlékeztet az 1972-es Burundi népirtást megelőző évekre. Vajon meddig uralkodhat a tutszi kisebbség a hutu többség felett egy olyan országban, ahol hivatalosan már eltörölték ezek az etnikai kategóriákat (a köztudatban tovább élnek), és mégis a tutszik uralják mind a politikai, mind a gazdasági életet? A ruandai vezetés, miután leszámolt a határok túloldalán tartózkodó, súlyos fenyegetést jelentő menekültekkel (erről részletesebben szólok a következő, Kongóról szóló fejezetben), és levezényelte a népirtók felelősségre vonását is (habár kétes sikerrel), a gazdasági fellendülés korszakát hozta Ruanda számára. Azonban Ruanda dinamikus népességnövekedése ${ }^{397}$ a rendelkezésre álló szűkös erőforrások miatt, valamint az elnyomó rendszer újra felszínre hozhatja azokat a feszültségeket, amelyeket napjainkban elfed a gazdasági növekedés.

\subsection{A nemzetközi közösség reakciója}

\subsubsection{ENSZ: A békefenntartás történetének egyik legsúlyosabb kudarca}

1994. március 14-én jelent meg a Biztonsági Tanács „Hogyan javíthatjuk az ENSZ békefenntartói tevékenységét?” c. jelentése, ${ }^{398}$ amelyben felhívta a figyelmet az ENSZ békefenntartó akcióinak elmúlt öt évben történt robbanásszerü növekedésére. A jelentés azonban azt is megállapította, hogy a békefenntartás iránti nemzetközi lelkesedés eltünőben van. Amikor a ruandai békefenntartással kapcsolatos igények felmerültek és a United Nations Assistance Mission in Rwanda (UNAMIR) felállításáról döntöttek a Biztonsági Tanácsban, az ENSZ összesen mintegy hetvenezer katonája állomásozott a világ különböző válságos pontjain a tizenhét ENSZ-misszió valamelyikében. ${ }^{399}$ A Békefenntartásért Felelős Osztály $(\mathrm{DPKO})^{400}$ kevés alkalmazottal dolgozott, és folyamatosan túlterhelt volt.

Ugyanakkor 1993-ban az ENSZ addigi békefenntartói történetének egyik legsúlyosabb veszteségével szembesült, amikor a szomáliai misszió egy kudarcba

\footnotetext{
397 2050-re várhatóan mintegy 22 millió lakosa lesz, bár most is a legsűrübben lakott ország Afrikában. Forrás: Population Institute (http://www.populationinstitute.org/external/files/Rwanda.pdf), CIA World Factbook (https://www.cia.gov/library/publications/the-world-factbook/geos/rw.html), [2012.09.04.]

${ }^{398}$ Improving the capacity of the United Nations for peace-keeping of 14 March 1994. (S/26450).

${ }^{399}$ Power, Samantha (2001a)

${ }^{400}$ Vezetője a gánai diplomata, Kofi Annan, későbbi ENSZ-főtitkár
} 
fulladt akciója során pakisztáni és amerikai kéksisakosok életüket vesztették ${ }^{401}$. A félresikerült szomáliai misszió súlyos hatást gyakorolt az ENSZ-tagállamok békefenntartás irányában mutatott elkötelezettségére.

Az arushai egyezmények aláírásának hatékony ellenőrzése érdekében 1993 után Ruandában is szükségessé vált az ENSZ-békefenntartók jelenléte. Az UNAMIR későbbi főparancsnoka, Roméo Dallaire a helyzet felmérése érdekében Ruandába utazott, majd 4500 katonát kért (habár nem volt tisztában a történelmi előzményekkel, sem a rejtett társadalmi feszültségekkel) a sikeres UNAMIR misszióhoz. Azonban a Biztonsági Tanács tagjai közül senki nem támogatta teljes szívvel a missziót, kivéve Franciaországot, aki azonban a Habyarimana-rezsim támogatójaként nem tudta meggyőzni a többi BT-tagot, hogy erős és jól felszerelt békefenntartókat küldjön Ruandába. Még ez az erőteljes támogató is csak ezer főnyi békefenntartót küldött volna a kis afrikai országba. Az Amerikai Egyesült Államok egy százfős(!) jelképes alakulat Ruandába küldését vetette fel. Az UNAMIR végül 2548 fővel indult Ruandában. Költségvetését 1994. április 4-én, két nappal a népirtás kezdete előtt hagyták jóvá. A késleltetett források és egyéb adminisztratív problémák miatt azonban az UNAMIR folyamatosan alapvető felszerelési és utánpótlási hiányokkal küzdött. ${ }^{402} \mathrm{Az}$ UNAMIR megalapítását lehetővé tévő 872. határozat, amelyet 1993 októberében fogadtak el, expliciten felkérte a fötitkárt, hogy igyekezzen megtakarításokat eszközölni az UNAMIR tevékenységének tervezésekor és rendszeresen számoljon be ilyen irányú erőfeszítéseinek eredményéről. ${ }^{403}$

Ha ez nem lett volna elég, az UNAMIR mandátuma is rendkívül szükösre sikeredett. Egyrészt a kis létszám, másrészt a szomáliai kudarc megismétlődésétől való félelem hatására a mandátum messze volt attól, ami elég lett volna az arushai egyezmények életbe léptetésének garantálásához. ${ }^{404}$ A mandátum a következő elemeket tartalmazta: ${ }^{405}$

- A fegyverszünet-egyezmény betartásának ellenőrzése, amely ún. kantonok és gyülekező zónák kialakítását, valamint új demilitarizált zóna kijelölését és más demilitarizációs eljárásokat írta elő.

\footnotetext{
${ }^{401}$ Erről részletesebben szólok

${ }^{402}$ Report of the Independent Inquiry into the actions of the United Nations during the 1994 genocide in Rwanda, S/1999/1257

${ }^{403}$ Ibid, 39.o.

${ }^{404}$ Human Rights Watch/FIDH interview, Plainsboro, New Jersey, June 14, 1996; Adelman and Suhrke, Early Warning, p. 35-36

${ }^{405}$ S/1999/1257.8.o.
} 
- A biztonsági helyzet ellenőrzése az átmeneti kormány mandátumának végén, a választásokhoz vezető időszakban.

- Segítség a taposóaknák eltávolításában, főként kiképző programokkal.

- A felek kérésére vagy saját kezdeményezésként nyomozás a harcoló felek fegyveres erőinek integrálásáról szóló egyezmény be nem tartásával kapcsolatban, figyelemmel követni ezeket az eseteket a felelős féllel együtt és, ha szükséges, jelenteni a főtitkárnak.

- A ruandai menekültek repatriálásának és a belső menekültek újratelepítésének ellenőrzése, hogy rendezetten és biztonságosan zajlik-e.

- A humanitárius segélyszervezetek koordinációjának segítése a katasztrófaelhárítókkal együtt.

- A csendőrség és rendőrség tevékenységével kapcsolatos incidensek nyomozása és ezekről jelentés küldése ${ }^{406}$

Az UNAMIR elvileg 1993.november elsején kezdte meg müködését, de a kontingensek lassú és sporadikus Ruandába érkezése miatt csak öt hónappal később érte el a tervezett 2548 fős létszámot.

Az UNAMIR parancsnoka, Roméo Dallaire 1993 novembere és 1994 áprilisa között többször is figyelmeztette feletteseit, hogy Ruandában általánossá vált a lakosság felfegyverzése, kiképzése, politikusok meggyilkolása, erőszakos demonstrációk. Többször is kérte, hogy bővítsék az ENSZ-erők mandátumát, valamint bocsássanak több embert a rendelkezésére. Kéréseit különös eréllyel támasztotta alá a már említett 1994. január 11-i távirat.

Miután április 6-án lelőtték Habyarimana elnök gépét, és elkezdődött a népirtás, az egyik első célpontot a mérsékelt hutu politikusok jelentették. Az egyik első politikai gyilkosság (Agathe Uwilingiyimana) során a népirtó rezsim tíz belga békefenntartót is megölt, akik a célpontot védelmezték. Belgium úgy döntött, hogy kivonja békefenntartóit Ruandából. Nem akart dicstelenül távozni, így amerikai támogatással kampányba kezdett az UNAMIR teljes kivonásáért. Habár ezt az erőszak eszkalálódása miatt nem sikerült elérni, április 21-én a Biztonsági Tanács megszavazta az UNAMIR létszámának 270 före csökkentését. ${ }^{407}$

\footnotetext{
${ }^{406}$ Report of the Independent Inquiry into the actions of the United Nations during the 1994 genocide in Rwanda S/1999/1257, 8.o.

${ }^{407}$ Ibid., 22.o.
} 
A ruandai helyzet azonban súlyosbodott, így bizonyos afrikai vezetök (közülük a legfontosabb szerepet a Biztonsági Tanács nigériai elnöke játszotta) nyomására egy újabb, jobban felszerelt és nagyobb létszámú ruandai ENSZ-misszió alapításának szükségessége merült fel. Hosszas tárgyalások után 1994. május 17-én a Biztonsági Tanács elfogadta a 918.határozatot, amelyben az UNAMIR létszámát 5500 főben maximálta, és fegyverembargót rendelt el Ruandában. Azonban a megerősített és UNAMIR II-nek átkeresztelt misszióba néhány kisebb afrikai kontingens kivételével a tagállamok húzódoztak katonákat küldeni. 1994. július 25-re még mindig csak 550 katonát sikerült verbuválni, az engedélyezett létszám egytizedét. ${ }^{408}$ (Július 18-ra az RPF már elfoglalta Ruandát és megállította a népirtást)

Mi lehet az oka annak, hogy az ENSZ-nek nem sikerült kellőképp mozgósítania tagállamait? Hogy fordulhatott elő, hogy a genocídium „kellős közepén” az ENSZcsapatok létszámát radikálisan csökkentették? Miért nem sikerült időben összegyüjteni az UNAMIR II katonáit? És összességében, hogyan állhatott tétlenül az Egyesült Nemzetek Szervezete a huszadik század egyik legsúlyosabb népirtása előtt?

Ezeket a kérdéseket igyekezett megválaszolni az a tényfeltáró bizottság, amelyet Kofi Annan 1999 márciusában állított fel azzal a céllal, hogy részletes vizsgálatot folytassanak az ENSZ-szervezet hiányosságairól, amelyek a kudarchoz vezettek. A Bizottság jelentése 1999. december 15-én jelent meg és a következőkben határozta meg az ENSZ ruandai népirtás során elkövetett hibáit:

A jelentés megállapította, hogy az ENSZ az 1994 tavaszán lezajlott népirtás előtt és után súlyos hibákat követett el, amelyekért a felelösség a fötitkárt, a titkárságot, a Biztonsági Tanácsot, az UNAMIR-t és az Egyesült Nemzetek Szervezete tagállamainak szélesebb körét egyaránt felelősség terheli. A népirtás megelőzéséhez vagy megállításához sokkal jelentősebb anyagi és katonai forrásokra lett volna szükség, valamint a tagországoknak felelősséget kellett volna vállalniuk és elkötelezniük magukat a népirtás elleni harc mellett.

Az UNAMIR azonban már kezdetben is jelentős hátrányokkal indult: mérete kisebb volt, mint amennyit a terep kívánt volna, lassan érte el teljes létszámát és a kontingensek müködését nem sikerült összehangolni. Számos kontingens hiányos felszereléssel érkezett. A legtöbb egységet úgy jellemzi a jelentés, hogy csak 1-2 napi ivóvíz, élelem és 2-3- napra elegendő tartalék benzinnel rendelkeztek. A legégetőbb

${ }^{408}$ Ibid., 25.0. 
azonban a lőszer- és kézifegyverhiány volt. Az UNAMIR mandátumát úgy határozták meg, hogy feltételezték: a békefolyamat sikeres lesz. Néhány héttel az UNAMIR felállítása előtt az Azonnali, Bírói Ítélet Nélküli Kivégzéssel Foglalkozó Emberi Jogi Bizottság rapportőre rendkívül aggasztó jelentést írt a ruandai helyzetről: felhívta a figyelmet arra, hogy súlyos emberi jogi jogsértések zajlanak Ruandában, és hosszasan tárgyalta egy esetleges népirtás lehetőségét. Ez a jelentés azonban nem jutott el Dallaire-hez, sem más szakértőkhöz, akik az UNAMIR részleteiért felelősek voltak. Ez a részlet arra utal, hogy az ENSZ szervezetén belül az egyes szervek közötti együttműködés hiányára utal.

Az 1994. január 11-i táviratban Dallaire informátora felfedte egy fegyverraktár helyét, Dallaire pedig engedélyt kért, hogy rajtaütéssel megszerezze a fegyvereket. Felettesei azonban úgy vélték, hogy ez a rajtaütés túlmegy az UNAMIR mandátumában megfogalmazottakon, és nem adtak rá engedélyt. A másik két információra (kormányerők belga békefenntartók kivégzésével akarják távozásra bírni a belga kontingenst, valamint civileket vetnek alá fegyveres kiképzésnek és céljuk feltehetőleg tutszik tömeges kivégzése) semmiféle válaszlépés nem érkezett az ENSZ részéröl. A tényfeltáró bizottság ezt érthetetlennek nevezi, és kiemeli, hogy a fötitkárt és a

Biztonsági Tanácsot nem tájékoztatták a távirat tartalmáról. A Biztonsági Tanács a távirat tartalmának ismeretében felülvizsgálhatta volna az UNAMIR mandátumát, amely nyilvánvalóan nem volt alkalmas a kialakult helyzet kezelésére.

A Habyarimana elnök gépének lelövése utáni napokban a föhadiszállásnak küldött UNAMIR-üzenetekből az tünik ki, hogy az UNAMIR vezetői nem igazán értették, mi zajlik. Nem voltak tisztában azzal, hogy milyen jelentősebb politikai és katonai szereplők léptek akcióba és mi a céljuk pontosan. Teljes fejetlenség uralkodott az UNAMIR-on belül: az ENSZ-haderő maga sem tudta eldönteni, hogy mi lenne a feladata, illetve az egyes kontingensek közötti kommunikáció sem müködött megfelelően. Nem volt világos, hogy kinek mi a feladata. Így fordulhatott elő, hogy az UNAMIR látszólag vállalta bizonyos politikusok védelmét, de a milíciák fenyegetésének hatására elálltak szándékuktól (az Agathe Uwilingiyimanát védő belga kéksisakosok például a milíciák felszólítására önként letették a fegyvert). Ez arra utal, hogy kétségek merültek fel a katonákban az UNAMIR mandátuma kapcsán, valamint nem volt megfelelő a haderő irányítása és ellenőrzése. A helyzetet tovább súlyosbította Belgium csapatkivonása, valamint egyes országok saját állampolgáraik evakuálására tett erőfeszítései. Különösen fájó volt Dallaire számára azt látni, hogy az 
evakuálás során hirtelen elegendő (és jól felszerelt!) katona érkezett Kigaliba ahhoz, hogy érdemben meg lehessen akadályozni a vérontást. Ezek az alakulatok azonban saját állampolgáraik evakuálása után elhagyták Ruandát.

A bizottság kiemelte, hogy a Biztonsági Tanácsot súlyos felelősség terheli április 21-i döntéséért, amikor az UNAMIR létszámát radikális csökkentették. A bizottság a Biztonsági Tanács döntését „,nehezen igazolhatónak” találta.

Miután néhány nappal később felmerült, hogy újabb haderőt küldenek Ruandába UNAMIR II néven, a Biztonsági Tanács ismét késlekedett a döntéssel (a főtitkár április 29-én kérte a korábbi döntés felülvizsgálatát, amelyröl végül május 17-én született döntés), a tagok nem tudtak egységesen fellépni. A Biztonsági Tanács munkáját az is negatív irányba befolyásolta, hogy nem állandó tagjai között abban az évben éppen ott volt Ruanda, ráadásul a népirtó kormány által képviselve. Nyilvánvaló, hogy a Ruandát az ENSZ BT-ben képviselő politikusok beszámoltak Kigaliban tartózkodó kollégáiknak a Biztonsági Tanácsban tapasztalt kelletlen, beavatkozás-ellenes hangulatról, és ezzel csak olajat öntöttek a népirtás tüzére. Ennek ellenére soha egyetlen tag sem kérte, hogy Ruanda tagságát függesszék fel.

Olyan helyzetben, amikor minden nap emberek tízezreinek élete múlhat az új ENSZ-csapatok érkezésén, a Biztonsági Tanács késlekedése súlyos hiba.

Az ENSZ, bizonyos tagországaival együtt, folyamatosan a békefolyamathoz való visszatérés fontosságát hangsúlyozta ahelyett, hogy közbelépett volna a népirtás megakadályozása érdekében, vagy legalább hangot adott volna annak, hogy elítéli a ruandai kormányt a genocídium miatt. A helyzet ilyen súlyos félreértelmezése intézményi gyengeségekre, valamint az elemző képesség hiányára utal az ENSZ szervezetén belül.

A tagországok beavatkozásra irányuló politikai akaratának teljes hiánya azzal magyarázható, hogy Ruanda stratégiai szempontból viszonylag jelentéktelen ország, és a tagállamok kettős mércét alkalmaztak. Ahol saját érdekeiket is veszélyben érezték, ott könnyebben szántak eszközöket és forrást a katasztrófa elhárítására. Ruandában azonban nemcsak először (UNAMIR), hanem a népirtás hatására sem (UNAMIR II) voltak hajlandóak katonát és pénzt áldozni (az RPF hamarabb meghódította Ruandát, mint hogy az UNAMIR II elindításához szükséges létszám összegyült volna). Ennek oka az információhiány is lehetett. Az Annan által megbízott szakértők számos tagország képviselőivel készítettek interjút és többen is panaszkodtak a kapott információk gyenge minőségére. Ezért felelősség terheli egyrészt a 
Békefenntartásért Felelős Osztály vezetőjét, Kofi Annant, másrészt azokat a tagállamokat, amelyek esetleg tisztában voltak a ruandai sajátosságokkal, információikat azonban nem osztották meg a Titkársággal.

Összességében tehát az UNAMIR az arushai egyezmények betartását ellenőrző békemisszióként jött létre, a népirtás azonban a döntéshozókat rá kellett volna bírja a mandátum megváltoztatására és a megváltozott feltételek mellé megfelelő erőforrásokat kellett volna rendelni.

\subsubsection{Afrikai Egységszervezet: a szolidaritás határai ${ }^{409}$}

Az Afrikai Egységszervezet vezetői Habyarimana gépének lelövése után viszonylag gyorsan reagáltak: nyilatkozatban ítélték el Agathe Uwilingiyimana és védői, valamint számtalan ruandai civil meggyilkolását. Három nap múlva az afrikai vezetők már a Biztonsági Tanácshoz fordultak azzal a kéréssel, hogy szélesítsék ki az UNAMIR mandátumát. Arra az április közepén érkező hírre, miszerint a Biztonsági Tanács az UNAMIR erőteljes létszámcsökkentését, esetleg teljes felszámolását fontolgatja, az Afrikai Egységszervezet fötitkára levélben fejezte ki aggodalmát az ENSZ-főtitkár Boutros-Boutros Ghalinak. Az Egységszervezet munkatársai április, május és június folyamán lobbiztak a fokozott ruandai ENSZ-szerepvállalásért az Amerikai Egyesült Államok, Franciaország, Belgium és más nyugati országok delegációinál is, azonban nem jártak sikerrel.

Májusban Nelson Mandela elnöki beiktatásakor Johannesburgban az Egységszervezet főtitkára találkozott a zimbabwei, zambiai, tanzániai, gánai, nigériai, namíbiai és szenegáli államfőkkel, akik kérésére mindannyian hajlandóak lettek volna kontingenseket küldeni az UNAMIR megerősítésére Ruandába. Etiópia és Mali szintén felajánlotta katonai segítségét. Ugyanezen ceremónia alkalmával az OUA (Afrikai Egységszervezet) főtitkára beszélt az afrikai felajánlásról az ENSZ-főtitkárával és Al Gore amerikai alelnökkel: logisztikai segítséget kért az afrikai kontingensek számára. A megbeszélések azonban semmilyen eredményre nem vezettek: az első afrikai csapatok az UNAMIR II. keretében csak három hónappal a népirtás vége után, októberben léptek Ruanda területére.

A népirtást azonban az Afrikai Egységszervezet sem nevezte nevén. 14 afrikai kormányfő június elején elítélte a genocídiumot, ez azonban nem jelentett akadályt az

${ }^{409}$ OAU (2000): 142-143.o. 
Afrikai Egységszervezet csúcstalálkozóján, ahol a népirtásért felelős Sindikubwabo vezette kormányt Ruanda hivatalos képviselőjeként fogadták.

Az Afrikai Egységszervezet marginális szerepe a ruandai konfliktusban nem csak a politikai akarat hiányára vezethető vissza. A tagországok forráshiánya miatt aktívabb közremüködésre lett volna szükség az ENSZ, valamint a régión kívüli gazdagabb országoktól. Az arushai egyezmények aláírásához vezető tárgyalásokon az Egységszervezet még aktív mediátorszerepet játszott, a szerződés főbb pontjainak ellenőrzésében és betartatásában azonban az ENSZ már nem támaszkodott a régió országaira. Pedig ha az ENSZ -a sokat hangoztatott retorikának megfelelően, mely szerint igyekszik jobban támaszkodni a regionális és szubregionális szervezetekrevalóban kijelölte volna az Afrikai Egységszervezet szerepét a konfliktuskezelésben és békefenntartásban (ezen feladatokban az OAU nagy valószínüséggel szívesen vállalt volna aktívabb részt), a jobb helyi ismereteire támaszkodva talán elkerülhető lett volna a népirtással járó végeredmény. ${ }^{410}$

\subsubsection{Belgium: Hátraarc}

A belgák relatíve fontos szerepet játszottak Ruandában a genocídium elött, és jelentős belga kolónia élt és dolgozott Kigaliban. Az RPF 1990. októberi betörése után belga csapatok érkeztek Kigaliba (1700 fö), hogy megvédjék a belga állampolgárokat. A külföldieket azonban semmilyen veszély nem fenyegette az RPF hadjárata miatt. Ugyanakkor a belga miniszterelnök és külügyminiszter Uganda, Kenya és Ruanda miniszterelnökével együtt regionális mediáció keretében próbált megoldást találni a ruandai kérdésre Kelet-Afrikában. A tárgyalások sikertelensége hozzájárult a belga csapatok gyors kivonásához (november elsejével távoztak), és ráébresztette a belga politikát, hogy a békefenntartás korántsem egyértelmü feladat. ${ }^{411}$ A katonai szerepvállalás szempontjából érdemes megemlíteni, hogy 1991-ig hagyományosan Belgium látta el Ruandát katonai segélyekkel, 1991 után azonban többé nem szállított halálos fegyvereket az országba, szerepét Franciaország vette át. ${ }^{412}$

Miután Martens (az akkori belga miniszterelnök) visszatért kelet-afrikai diplomáciai útjáról 1990-ben, igyekezett meggyőzni az EU-t, hogy vállaljon

\footnotetext{
${ }^{410}$ Eriksson, John (1996): The International Response to Conflict and Genocide: Lessons from the Rwanda Experience, Chapter 5: Overall Findings and Recommendations

${ }^{411}$ Prunier (1995), 106-107.o.

${ }^{412}$ Braeckman, Colette (1994): Génocide au Rwanda. Paris: Fayart
} 
békefenntartói szerepet Ruandában, ez a kísérlet azonban kudarcba fulladt. ${ }^{413}$ Ezután Belgium nem vállalt jelentősebb katonai és diplomáciai szerepet az UNAMIR Ruandába küldéséig.

Ez azonban nem jelentette azt, hogy a belgák lemondtak Ruandáról: a következő években a belga diplomaták vezetésével az emberi jogokért küzdő diplomáciai csoport alakult Kigaliban (amelynek az amerikaiak tagjai voltak, a franciák azonban nem). Ez a csoport erőteljesen lobbizott Habyarimana elnöknél a koalíciós kormány elfogadásáért és az arushai egyezmények betartásáért.

Az UNAMIR 1993. októberi felállításánál Belgium küldte a legnagyobb nyugati kontingenst, sőt a helyzet élesedésével igyekezett nyomást gyakorolni az ENSZ-re, hogy szélesítse az UNAMIR mandátumát. A helyszínen tartózkodó diplomaták közül a belgák voltak a legjobban informáltak. Tudtak róla, hogy Dallaire informátora szerint a hutu szélsőségesek néhány belga békefenntartó meggyilkolásával akarják kikényszeríteni a belga katonák távozását. Tisztában voltak vele, hogy milyen veszélyt vállalnak békefenntartóik. ${ }^{414}$ A szélsőséges hutu szervezetek már hónapokkal korábban ellenségnek kiáltották ki a belgákat, akiket tutszibarátnak és az arushai egyezmények támogatóinak tartottak. Az RTLMC, a hutu szélsőségesek adója nyíltan a hutuk ellenségének nevezte a belga békefenntartókat, és április 6-án az RPF-fel együtt Habyarimana elnök gépének lelövésével is megvádolták Belgiumot.

Amikor kormánykatonák valóban megöltek tíz belga kéksisakost (akik Agathe Uwiligiyimana miniszterelnökasszonyt védelmezték) Habyarimana elnök gépének lelövése után, a belga kormány az előzetes információk ellenére pontosan úgy reagált, ahogy a hutu szélsőségesek várták: a katonái kivonásával.

Sok belga katona nem is akart távozni, és szégyellte magát kormánya döntése miatt. Luc Marchal ezredes, a belga kontingens vezetője később így írt: „Politikai vezetőinknek tudniuk kellett volna, hogy az UNAMIR elhagyásával emberek, asszonyok és gyerekek ezreit biztos halálra ítéljük." ${ }^{\text {„15 }}$ Belgium kivonulása Ruandából nem volt diadalmenet, és a belga katonák már az UNAMIR mandátumának szűk értelmezését is katonai hitelességük megkérdőjelezéseként élték meg, a kivonás bejelentése után pedig úgy érezték, hogy joggal minősíthették őket gyávának és

${ }^{413}$ Adelman (2009): The Role of Non-African States in the Rwandan Genocide Centre for Refugee Studies, York University, 4.o.

${ }^{414}$ Sénat de Belgique:"Rapport", 6 décembre 1997.

${ }^{415}$ Des Forges (1999), 620.o. 
felelőtlennek. Nem csoda, hogy sokan undorodva hajították el kék sapkájukat, amikor visszatértek Belgiumba. ${ }^{416}$

Ha a kivonulás nem lett volna elég, belga diplomaták a háttérben azért kezdtek lobbizni a Biztonsági Tanácsban, hogy az egész ENSZ-haderő befejezze müködését Ruandában (valószínüleg saját zavarukat leplezendő e nemtelen távozás miatt). ${ }^{417}$ Erőfeszítéseiket április 21-én részleges siker koronázta, hiszen a Biztonsági Tanács az UNAMIR létszámának radikális csökkentéséről döntött.

A dicstelen távozás után Belgium nem vállalt további szerepet a népirtás megelőzésében.

Belgium képviseletében Guy Verhofstadt miniszterelnök 2000. április 6-án, a Kigaliban a genocídium hatodik évfordulóján rendezett megemlékezésen hivatalosan is bocsánatot kért „országa és nemzete nevében” és vállalta a felelősséget a belga békefenntartók kivonásáért.

\subsubsection{Franciaország: a Fashoda-szindróma ${ }^{418}$ hatása}

Franciaország jelenlétét gazdasági haszonszerzés, valamint hagyományosan afrikai történelmi szerepének megőrzése, fejlesztése motiválta Ruandában. A francia külügyi szolgálat azonban másképp értékelte a francia motivációt: Hubert Védrine 1998-ban a francia parlamenti vizsgálóbizottságnak úgy nyilatkozott, hogy Ruandában a francia külpolitikának két célja volt: ${ }^{419}$

1. Ruandának hagyományosan jó kapcsolatai voltak Franciaországgal, erre apellálva a franciák segítettek megőrizni az országhatárokat és fenntartani a közrendet és közbiztonságot, míg a gazdasági és politikai fejlődést is elösegítették

2. Meggyőzni Habyarimanát, hogy a tutszikkal megosztva vezesse Ruandát és alakítson ki demokratikus intézményrendszert

\footnotetext{
${ }^{416}$ Adelman (2009), 5.o.

${ }^{417}$ Alison des Forges emberjogi aktivista vallomása 1998. május 5-én a e Subcommittee on International Operations and Human Rights elött, http://www.ess.uwe.ac.uk/Rwanda/Rwanda2.htm\#N_3, [2012.08.22.]

${ }^{418} \mathrm{Az}$ Afrika gyarmatosításáért folyó hajsza egyik legforróbb pontja volt a fashodai incidens, amikor 1898-ban a Fehér-Nílus partján a francia Marchand százados és az angol Kitchener tábornok csapatai néztek farkasszemet egymással. A franciák nem vállalták a háborút és visszavonulót fújtak. A francia „grandeur”-t érzékenyen érintette a veszteség, és Afrikában mindig igyekezett megőrizni, illetve növelni a frankofon befolyási övezetet az anglofon területek kárára. Mivel Ruanda éppen az anglofon és frankofon Afrika közötti határvonalon fekszik, és az RPF (a hadsereg, amely meghódította Ruandát, és ezzel véget vetett a népirtásnak) Ugandából, egy brit befolyási övezethez tartozó országból indult, a franciák érzékenyen reagáltak Ruanda esetleges „elvesztésére”

${ }^{419}$ Ibid, 26.o.
} 
Bármi volt is Franciaország célja, a népirtás után temérdek kritikát kapott a Habyarimana-rezsim túlzott támogatásáért. Olyan vádak is elhangzottak, amelyek szerint Franciaország fegyverezte fel és képezte ki a népirtás elkövetőit, valamint az utolsó pillanatig szimpatizált a Habyarimana-rezsimmel. A következőkben megvizsgáljuk a fentiek valóságalapját.

Franciaország Habyarimana rendszernek adott aktív katonai segítő szerepe már 1990 októberében, az RPF-invázió idején hangsúlyos volt. Franciaország eleinte 150 katonát küldött az országba, majd Belgium távozása után a létszámot 350 före emelte. A katonák hivatalosan közzétett megbízatása a Ruandában élő francia állampolgárok védelme volt, a valóságban azonban a kormánykatonákat segítették a reptér biztosításával, az úttorlaszok védelmével és logisztikai támogatással. ${ }^{420}$ Franciaország már korábban is bonyolódott hasonló akciókba más frankofon afrikai országokért, így voltak a régióban állomásozó katonái, akiket átcsoportosíthatott. Ruanda esetében az is Habyarimana kezére játszott, hogy a franciák az RPF katonáit azonosították az anglofon befolyási övezettel, hiszen Ugandából érkeztek. „A Mitterand-rezsim szemében az ugandai támogatás egy anglofon összeesküvés része volt, hogy átvegyék az uralmat frankofon Afrika bizonyos részei fölött ${ }^{421}$, tehát a Habyarimana-rezsim védelme (és így a hutu felsőbbrendűséget hirdető ideológiáé, amelynek lényeges elemeihez a Mitterandrezsim már szorosan kapcsolódott) egy, a frankofóniát és Franciaország afrikai szerepvállalását védelmező szélesebb védelmi stratégia részévé vált. [...]”,422

Francia katonai tanácsadók széleskörü tevékenységet vállaltak a következő években is (többek között jelen voltak az országban az RPF 1992-ben indított támadásakor is): tanácsokat adtak az elnöknek, kiképezték a ruandai hadsereg újoncait, fontos katonai és civil objektumok védelmét látták el, részt vettek az úttorlaszok felügyeletében, és a foglyok kihallgatásában. ${ }^{423}$

Franciaország a Habyarimana-rezsim felfegyverzésében is aktívan részt vett. A katonai segítségnyújtás és a rezsim felfegyverzése morálisan talán az atrocitások kezdetéig magyarázható lenne azzal, hogy Franciaország nem volt tisztában partnere terveivel. Habyarimana gépének lelövése után azonban már nehéz lenne igazolni az

\footnotetext{
${ }^{420}$ Adelman (2009), 28.o.

${ }^{421}$ Prunier (1995), 102-107.o.

422 Clapham, Christopher (1998): Rwanda: The Perils of Peacemaking. Journal of Peace Research. Vol. 35, No. 2 (Mar., 1998), 199.o.

${ }^{423}$ Adelman , Howard and Suhrke, Astri (1996): Early Warning and Response: Why the International Community Failed to Prevent the Genocide, Disasters: The Journal of Disaster Studies and Management 20.4 (December 1996): 295-304.o.
} 
együttmüködést, amely folytatódott Franciaország és a népirtást kitervelő és megszervező rezsim között. Április 8-án és 9-én Franciaország 500 francia katonát küldött Kigaliba, hogy segítsék a francia állampolgárok evakuálását. A három repülőgép, amivel érkeztek, bizonyos ruandai állampolgároknak is segített elhagyni a helyszínt. Közülük sokan a Habyarimana-rezsim kegyeltjei voltak. Többek között a francia gépek egyikével távozott Kigaliból Habyarimana elnök felesége is. A francia gépek egyetlen tutszit vagy mérsékelt hutut sem evakuáltak. ${ }^{424} \mathrm{~A}$ francia haderő április 12-re az utolsó emberig eltünt Ruandából. Ahogy a francia szakértő, Callamard fogalmaz: a „kiválasztottakkal” távozó repülőgépekkel kapcsolatban „,asszonyok, férfiak és gyermekek képe ugrik be, akik a francia nagykövetség kerítését próbálják megmászni, valamint ruandai alkalmazottaké, akiket magukra hagytak, hogy egyedül nézzenek szembe a genocídiummal. Közben pedig azokat, akik éveken keresztül ültették az etnikai gyülölet magvait, és hozzájárultak egy halálos gépezet felépítéséhez, francia gépek repítették el a biztonság felé." ${ }^{425}$

Ha ez nem lett volna elég, a három francia gép közül az egyik fegyverekkel volt tele, amelyet átadtak a ruandai kormányerőknek. Luc Marchal, a belga UNAMIR-erők parancsnoka később beszámolt róla, hogy szemtanúja volt, amikor a kigali reptérről a hadianyagot elszállították a FAR katonai táborához. ${ }^{426}$ Feltehetően azonban ezután Franciaország a híresztelésekkel és a kezdetben megjelent elemzések állításaival ellentétben a genocídium idején már nem adott el hadianyagot a népirtó rezsimnek. ${ }^{427}$

1994. április 12. után tehát a franciák távoztak Ruandából, és sorsára hagyták az országot. A következő két hónapban Franciaország nem mutatott hajlandóságot arra, hogy szerepet vállalna a ruandai helyzet megoldásában. Éppen ezért sokakat meglepetésként ért Mitterand bejelentése június közepén, hogy Franciaország humanitárius okokból csapatokat küldene Ruandába. A pálfordulás oka, hogy a francia kormányra hatalmas belső nyomás nehezedett bizonyos társadalmi csoportok részéről, hogy vessen véget a vérontásnak. Hiszen a népirtásról részletes sajtóhírek érkeztek, és számos szakértő kritizálta az aktív francia szerepvállalást a Habyarimana-rezsim

\footnotetext{
${ }^{424}$ Des Forges (1999), 613.o.

${ }^{425}$ Callamard, Agnes (2000): French Policy in Rwanda, 176.o. In: Adelman, Howard and Suhrke, Astri (2000): The Path of a Genocide: The Rwanda Crisis from Uganda to Zaire. Transaction Publishers, New Jersey

${ }^{426}$ Luc Marchal ezredes interjúja a BBC-vel, "When Good Men do Nothing”, 1994 augusztus; Jean de la Gueriviere, "Un officier belge maintient ses déclarations sur l'attitude de la France lors du génocide rwandais", Le Monde (France), 1995.július 23.

${ }^{427}$ Adelman (2009), 10.o.
} 
támogatásában. ${ }^{428}$ Franciaország azt is jelezni akarta, hogy még mindig lehet rá számítani Afrikában, föleg ha az angol befolyás gyengítéséről van szó. ${ }^{429}$

A későn érkezett francia segítséget (Opération Turquoise) sokan nem nézték jó szemmel. Néhány életben maradt tutszi pap például felhívást tett közzé, amelyben élesen kritizálta a francia hozzáállást: „Úgy véljük, hogy Franciaország ún. humanitárius akciója cinikus vállalkozás. Keserúen megjegyezzük, hogy Franciaország két hónapig egyáltalán nem reagált, amíg dühöngött a népirtás, bár jobban informált volt, mint bármely más ország. Soha nem emelte fel a hangját a politikai ellenzék meggyilkolása ellen. Soha nem gyakorolta a legkisebb nyomást sem Kigali önjelölt kormányára, bár megvoltak hozzá az eszközei." ${ }^{430}$ A kétkedők között volt az RPF is, amelynek vezetői azt gyanították, hogy Franciaország régi szövetségesének akar hadászati segítséget nyújtani. Ezt a félelmet indokolta az a tény is, hogy humanitárius misszióhoz képest az Opération Turquoise katonáit „túlságosan” felfegyverezték. ${ }^{431}$

Ami igazán dühítő volt a francia akcióban, amely ENSZ-felhatalmazással indult (a Biztonsági Tanács 1994.június 22-én fogadta el tíz támogató -köztük Ruanda népirtó kormányának képviselői- és öt ellenző szavazattal), hogy a katonák néhány órával a döntés után már rendelkezésre is álltak (2555 francia és 350 frankofon országból érkező katona). ${ }^{432}$ Ehhez képest az ENSZ Békefenntartásért Felelős Osztálya már egy hónapja dolgozott azon, hogy annyi katonát gyüjtsön a tagországoktól, hogy be lehessen indítani az UNAMIR II-t. Ez az eset is jól mutatja, hogy mennyire eltérő politikai akarat jellemezte az ENSZ-tagországokat a ruandai katonai szerepvállalás tekintetében. Az ENSZ-jelentés vizsgálóbizottsága meg is állapította: „szerencsétlen dolog, hogy a Franciaország és más országok által az Opération Turquoise részére felajánlott haderőt nem bocsátották már korábban az UNAMIR II. részére." ${ }^{433}$

Franciaország a csapatok megérkezése után azonnal ún. Biztonsági Zónát hozott létre az ország délnyugati részén. A zónába költözött néhány szerencsés tutszi, aki túlélte az előző hónapokat, és rengeteg hutu, akik az RPF elől menekültek. Így a zóna valóban életeket mentett (becslések szerint mintegy 12-15000 tutsziét) ${ }^{434}$, és megóvta Burundit a további hutu menekültáradattól. A Habyarimana-kormány propagandájának

\footnotetext{
${ }^{428}$ OAU(2000): Rapport sur le génocide au Rwanda, 136.o., 15.59. bekezdés

${ }^{429}$ Prunier (1995), 278-281.o.

${ }^{430}$ African Rights (1995): Rwanda- Death, despair and defiance, 1142.o.

${ }^{431}$ OAU(2000): Rapport sur le génocide au Rwanda, 137.o., 15.66. bekezdés

${ }^{432}$ Ibid., 137.o.15.65. bekezdés

${ }^{433}$ UN Security Council Report, S1999/1257, 49.o.

434 Millwood, David (1996): The International Response to Conflict and Genocide: Lessons from the Rwanda Experience, 55.o.
} 
eredményeképpen Ruanda hutu lakossága félt az RPF-hadseregtől, mint a tűztől. Élénken élt bennük az elképzelés, hogy a tutszik vezette katonaság végső célja a hutuk elpusztítása, de legalábbis kegyetlen bosszút akarnak majd állni tutszi testvéreik haláláért.

A Biztonsági Zónában keresett menedéket számtalan „génocidaire” is, köztük kormányzati tisztviselök, a FAR katonaságának tagjai, valamint a halálosztagok elkövetői. A francia katonák nem tartották vissza ezeket a radikális elemeket (nem is volt meg a megfelelő felhatalmazásuk rá), és nem korlátozták mozgásszabadságukat sem. Ennek eredményeképpen az elkövetők tömegével hagyták el Ruandát és menekültek át viszonylag rendezetten és biztonságos körülmények között a biztonsági zónán keresztül Zairéba. A radikális csoportok túléléséhez tehát nagyban hozzájárult a francia intervenció.

Az Opération Turquoise megítélése tehát meglehetősen vegyes. Sokan -joggalkritizálták a francia vezetést hutubarát elfogultságáért, amely lehetővé tette a gyilkosok tömeges Zairéba menekülését. Az RPF többször is kérte a népirtás elkövetőinek kiadását, vagy legalább letartóztatását, részletes bizonyítékokkal alátámasztva, Franciaország ezt azonban az intervenció semlegességére hivatkozva elutasította. Egyes beszámolók arra engednek utalni, hogy Franciaország még segített is megszervezni az elkövetők Zairéba szállítását ${ }^{435}$ és sokan a fegyvereiket is magukkal vihették. Ugyanakkor bár az Opération Turquoise későn érkezett, de így is több ezer szerencsés tutszi életét megmentette, és ez a pozitív eredmény vitathatatlan.

Franciaország viszonya napjainkig meglehetősen fagyos az RPF-ből alakult kormánnyal. Nicolas Sarkozy 2010-ben miniszterelnökként Kigaliba látogatott ${ }^{436}$, és igyekezett felmelegíteni a ruandai-francia kapcsolatokat. Beismerte, hogy Franciaország „súlyos hibákat követett el a helyzet megítélésében” a genocídiummal kapcsolatban, hivatalos bocsánatkérés azonban nem történt. ${ }^{437}$ Arra is ígéretet tett, hogy a Franciaország területén élő elkövetőket ${ }^{438}$ felelősségre vonják.

\footnotetext{
${ }^{435}$ Az UNAMIR II etióp kontingensének vezetője, Tadele Selasszié látta, hogy francia katonai járművek szállítottak FAR-katonákat a zairei határ felé, OAU (2000), 139.o., 15.75. bekezdés

${ }^{436}$ Ez volt az első alkalom, hogy az 1994-es genocídium után francia elnök Kigaliba látogatott

437 The Christian Science Monitor- Max Delany: Sarkozy admits France made 'serious errors' over Rwanda genocide, 2010.február 25. http://www.csmonitor.com/World/Africa/2010/0225/Sarkozy-admitsFrance-made-serious-errors-over-Rwanda-genocide, [2012.08.22.]

${ }^{438}$ A ruandai hatóságok becslése szerint akár 100 gyanúsított is élhet az országban
} 


\subsubsection{Amerikai Egyesült Államok: Szomália árnyéka}

1993 októberében a Szomáliában tartózkodó amerikai békefenntartók jelentős veszteségeket szenvedtek, amikor Mohammed Farah Aidid hadurat üldözve támadást indítottak Mogadishuban. Az akcióban 18 amerikai ranger meghalt és több mint hetvenen megsebesültek. ${ }^{439} \mathrm{Az}$ amerikai tévénézőkben maradandó nyomot hagyott, amint egy amerikai katonát félmeztelenül végighurcoltak Mogadishu utcáin, és a látottak hosszú időre elvették mind a politikai vezetés, mind az átlagemberek kedvét a békefenntartás támogatásától.

A szomáliai eset következménye az lett, hogy Clinton elnök bejelentette: kivonják Szomáliából az amerikai erőket. A kongresszusi nyomás hatására Clinton szigorú szabályokat állított fel, amelyek definiálták, hogy Amerika milyen ENSZ békefenntartó misssziókban vehet részt a jövőben. Bár a 25. Elnöki Direktívát (PDD25) csak egy hónappal a ruandai válság kezdete után írták alá, már 1994 áprilisában is elöírásai szerint alakították az amerikai külpolitikát. Az elnöki direktíva módosításai gyakorlatilag lehetetlenné tették a nemzetközi válaszokra adott gyors reagálást. ${ }^{440}$ Ahogy később Albright (az Egyesült Államok ENSZ-nagykövete 1994-ben) fogalmazott, Amerika csak akkor lett volna hajlandó beavatkozni, ha bizonyos kritériumok teljesülnek, amelyek lényegét a következökben foglalta össze: „ha az incidens valóban jelentős veszélyt jelent a nemzetközi békére, a missziónak világosan meghatározott céljai és végpontja van". ${ }^{441}$

Ezek a feltételek Ruanda esetében nem teljesültek egyértelmüen, így az Amerikai Egyesült Államok nem küldött csapatokat. Sőt, az amerikai állampolgárok április 9-i és 10-i sikeres evakuálása után az amerikai külügy gyakorlatilag nem foglakozott többé Ruandával. A napirendi pontok között Ruandát megelőzte Haiti és Bosznia is.

Amerikai azonban nem egyszerủen passzív volt Ruanda esetében, hanem kifejezetten negatív irányba befolyásolta például a ruandai ENSZ-békefenntartók sorsát. A szomáliai eset hatására széles körben elterjedt az a vélemény, hogy az ENSZ rosszabbul jár, ha erősítést küld és a misszió nem sikerül, mint ha tétlenül nézi végig az atrocitásokat. Mikor tehát Belgium bejelentette, hogy kivonja békefenntartóit az országból, és ehhez Amerika támogatását kérte, meg is kapta. Amerika aktívan

\footnotetext{
${ }^{439}$ Adelman (2009), 15.o.

440 Power, Samantha (2001a): Bystanders to genocide. http://www.theatlantic.com/magazine/archive /2001/09/bystanders-to-genocide/304571/, [2012.08.22.]

${ }^{441}$ Madeleine Albright tanúvallomása a Foreign Operations Subcommittee of the House Appropriations Committee elött, 5/5/94.
} 
kampányolt azért, hogy a belga békefenntartók helyett ne küldjenek másokat Ruandába, hanem az egész UNAMIR-t vonják ki. Ezt azzal magyarázhatjuk, hogy Szomáliában is a nehéz helyzetbe került pakisztáni békefenntartók segítségére siettek az amerikai katonák, akik közül sokan az életükkel fizettek. Amerika attól tartott, hogy ha bármely ország csapatokat küldene, és a misszió bajba kerülne, végül ismét Amerikának kellene mind anyagilag, mind katonailag kiköszörülni a csorbát. Mivel néhány afrikai ország és Madeleine Albright sem támogatta a teljes csapatkivonást, Amerika végül a csapatok létszámának drasztikus csökkentéséért lobbizott. A „sikeres” diplomáciai offenzívának köszönhetően április 21 -én a Biztonsági Tanács megszavazta az UNAMIR létszámának 2100-ról 270-re csökkentését.

A másik kérés, amelynek teljesítése nem kívánt volna túl nagy anyagi áldozatot amerikai részről, a népirtó üzeneteket sugárzó RTLCM rádió adásainak zavarása volt. Ezt Dallaire többször is kérte az ENSZ-től, és az Amerikai Egyesült Államok fejlett technológiájával segíthetett volna. Az adás zavarására készültek is tervek a Pentagonban, azonban a jelentős költségek miatt (óránként 8500 dollárba került volna alkalmanként az adás zavarása), valamint a kétséges eredmények okán végül semmilyen erőfeszítés nem történt amerikai részről az adás megzavarására.

Az amerikai közvélemény megnyugtatása és a morális következmények elkerülése érdekében a ruandai atrocitásokról szóló adásokban, interjúkban az amerikai külpolitika szakértői a genocídium kifejezés emlegetését gondosan kerülték. Erről heves vita kezdődött április végén kormánykörökben, de csak május 21-én adtak hivatalos engedélyt az államapparátusban dolgozóknak, hogy a „népirtási cselekmények” szókapcsolatot használják a ruandai események leírására.

Hogy magyarázható ez az obstruktív magatartás egy olyan ország részéről, amely az emberi jogok egyik élharcosának tartja magát és az egyik, ha nem a legfontosabb szereplője a nemzetközi kapcsolatoknak?

A válasz abban rejlik, hogy a szomáliai kudarc hatására az amerikai külpolitika céljai jelentősen megváltoztak. Az Amerikai Egyesült Államok vezetése nem akart szerepet vállalni egy olyan konfliktusban, amelyben a szüken definiált amerikai érdekek nem forogtak kockán. Másrészt a Kongresszusnak is meg kellett felelni, mintegy a ruandai eset kapcsán mutatott passzivitással demonstrálni, hogy az amerikai külpolitika sokkal óvatosabbá vált a békefenntartó missziók tekintetében. Ugyanakkor a politikai vezetők a genocídiummal szembeni tehetetlenséggel együtt járó erkölcsi stigmát is el 
akarták kerülni, ezért rendszeresen jelentéktelenebbeknek tüntették fel a Ruandában zajló atrocitásokat, mint amilyenek azok valójában voltak.

Pedig talán már az is gátat vethetett volna a tutszik és mérsékelt hutuk tömeges kiirtásának, ha az Amerikai Egyesült Államok nyíltan felemeli szavát a vérontás ellen. Erre utal, hogy amikor ez végül, hónapokkal a genocídium kezdete után megtörtént, hihetetlen hatása volt: azonnal eljutott az adminisztratív hierarchia legalsóbb szintjeire is. A nyugati Kibuye tartomány messzi hegyei közt tartott falusi megbeszélésen a helyi kormánytisztviselők arra intették az embereket, hogy hagyják abba az öldöklést, mert az USA ezt szabta a kormánnyal folytatott tárgyalások feltételéül. Arra is figyelmeztették a helyieket, hogy műholdak figyelik, mi történik és tájékoztatják a világot arról, mi zajlik Ruandában. Alison des Forges kiemelte, hogy ha ennek a félénk, elkésett figyelmeztetésnek is ilyen határozott és az egész országra kiterjedő hatása volt, akkor talán a nemzetközi közösség egyöntetű elítélő magatartása az atrocitások kezdetén már csírájában elfojtotta volna a népirtást. ${ }^{442}$

Alison des Forges emberi jogi szakértő az amerikai hozzáállást azzal is magyarázta, hogy az amerikai politikusok nem tudták elválasztani egymástól a genocídiumot, valamint a kormányerők és az RPF háborúját, hiszen a két esemény egymással párhuzamosan folyt. Azt is tévesen ítélték meg, hogy a népirtás befejezéséhez tüzszünetre lenne szükség. A kormányerők mindenáron végig akarták vinni tervüket, meg akarták tisztítani az országot a tutsziktól egyszer és mindenkorra, így ennek csak az RPF elöretörése vethetett gátat. Ha az RPF aláírta volna a tüzszüneti megállapodást, az elkövetők valószínüleg tovább folytatták volna a tutszi kisebbség felszámolását. ${ }^{443} \mathrm{~A}$ helyzet félreértése abból is adódhatott, hogy az amerikai diplomácia hagyományosan preferál országokkal és kormányokkal tárgyalni, ${ }^{444}$ így nem volt tisztában az RPF céljaival. Ruanda esetében is jobban bíztak a ruandai kormány tisztviselőiben, mint az RPF-erőkben, pedig a hivatalos szervek a háttérben népirtást szerveztek. A Kigaliban tartózkodó amerikai nagykövet, David Rawson, eklatáns példája volt a kormány jóindulatában bizakodó diplomatának. „Azt hiszem naiv, optimista politikusok voltunk...A reményteli jeleket kerestük, nem a baljóslatúakat. Valójában elfordultunk a

\footnotetext{
${ }^{442}$ Alison des Forges emberjogi aktivista vallomása 1998. május 5-én a e Subcommittee on International Operations and Human Rights elött, http://www.ess.uwe.ac.uk/Rwanda/Rwanda2.htm\#N_3, [2012.08.22.]

${ }^{443}$ Prunier, Gérard (1995)

444 Power, Samantha (2001a)
} 
baljós jelektől [...]" - emlékezett vissza Rawson. ${ }^{445}$ Az amerikai nagykövet nem tudta elhinni, hogy a Habyarimana-kabinetben dolgozók népirtást forgatnak a fejükben.

Az amerikai diplomácia azt a hibát is elkövette, hogy Melchior Ndadaye meggyilkolása után Burundiban elég jelentős hutu-tutszi etnikai tisztogatást tolerált, és így a térséggel foglalkozó amerikai diplomaták úgy tájékoztatták a döntéshozókat április elején, a népírtás kezdetén, hogy valószínüleg ez is csak egy újabb fellángolás lesz, amely viszonylag „elfogadható mennyiségü” etnikai eredetü emberölést produkál majd. David Rawson kiemelte, hogy a ruandai kultúrában és történelemben semmi nem utalt egy ilyen méretű erőszakhullámra. ${ }^{446}$ George Moose, az Afrikai Ügyekért Felelős Főosztály aligazgatója is alátámasztotta, hogy nehéz lett volna megjósolni, ami bekövetkezett: ,[...] túl korlátozott volt a képzelőerőnk.”447

Ez a magyarázat elfogadható lenne, ha az amerikai hírszerzésnek nem álltak volna rendelkezésére részletes jelentések arról, hogy mi folyik napról napra Ruandában. Ha a genocídium súlyosságát nem sikerült megérteni, az semmiképpen sem információhiányból fakadt. Szakértők (Samantha Power, Alan Kuperman, Howard Adelman) egybehangzó állítása szerint legkésőbb két héttel az elnöki gép lelövése után Clinton elnök világosan tisztában volt vele, hogy mi is az elkövetők szándéka és milyen nagyságrendekben zajlik a népirtás. Hogy csak két példát említsünk, április 26-án egy névtelen hírszerzési feljegyzés kijelentette, hogy Théoneste Bagosora ezredes és klikkje a teljes ellenzék és a tutszi kisebbség kiirtására készül. Május 9-én egy újabb jelentés megállapította, hogy a ruandai erőszak nem spontán, hanem a kormány által szervezett és az öldöklés előzetesen összeállított listák alapján folyik. ${ }^{448}$

Samantha Power, aki könyvet írt arról, hogy az amerikai államapparátus miért nem tud hatékony választ adni a genocídiumokra, a Külügyminisztérium hozzáállásában látja az egyik legfőbb problémát. A ruandai esetről szóló fejezetben, számos minisztériumi dolgozóval készített interjú és hosszas oknyomozás után megállapította, hogy a ruandai népirtással 1994 április-májusában nem foglalkozott egyetlen magas rangú tisztviselő sem a Külügyminisztériumban. Csak „,középvezetők” voltak kellően informáltak ahhoz, hogy a népirtás megakadályozásáért lobbizzanak, ők azonban a számtalan más, fontosabbnak tünő válság mellett nem tudták főnökeik figyelmét kellően Ruandára

445 Ibid.

${ }^{446}$ Power, Samantha (2001b): A Problem from Hell, New Republic Book, 348.o.

${ }^{447}$ Ibid, 348.o.

${ }^{448}$ Power, Samantha (2001a) 
irányítani. A közvélemény szintén nem mutatott különösebb felháborodást. Így erőteljes vezetés nélkül a rendszer a kockázatkerülö megoldásokra hajlott.

Április végén, nem sokkal Dallaire csapatainak távozása után (végül 503 békefenntartóval maradt Kigaliban) a Biztonsági Tanács nem állandó tagjai lobbizni kezdtek egy újabb, nagyobb létszámú és jobban felszerelt ENSZ-haderőért. Az Amerikai Egyesült Államoktól a tervek szerint csak logisztikai segítségre lett volna szükség, de az amerikai katonai vezetők erre sem mutattak túl nagy hajlandóságot. Hetekig nem egyeztek bele a Dallaire által javasolt tervekbe, aki kijelentette: „A két terv [t.i. az amerikaiaké és a Dallaire-é] közötti legföbb különbség a célokban mutatkozik [...]. Az én célom ruandaiak megmentése. Az övék, hogy kockázat nélkül cselekedjenek." ${ }^{\text {449 }}$ Mire a kért amerikai járművek végül június 19-én, egy hónappal az ENSZ kérése után befutottak, az RPF már elfoglalta Ruandát és megállította a vérengzést.

Az amerikai vezetés évekig nem ismerte el, hogy Ruanda kapcsán hibát követett volna el. Napjainkban azonban már világos, hogy a ruandai népirtás kapcsán mutatott passzivitás, sőt obstrukcionizmus a Clinton-adminisztráció egyik legsúlyosabb külpolitikai tévedése volt. Egyfajta bocsánatkérésnek minősülhet az, amit Clinton akkor amerikai elnök mondott Kigaliban 1998-as látogatásakor: „Részben azért vagyunk ma itt, hogy elismerjük: az Amerikai Egyesült Államok és a nemzetközi közösség nem tett annyit, amennyit lehetett és tudott volna tenni annak érdekében, hogy megakadályozza, ami történt...Talán furcsán hangozhat önöknek, föleg sokaknak, akik családtagjaikat vesztették el, de világszerte voltak olyan emberek, mint én, akik irodákban ültek nap nap után, és akik nem tudták felfogni ennek az elképzelhetetlen örvénynek a mélységét és gyorsaságát, amely elnyelte Ruandát."450

A következő részben a ruandai népirtás utóhatásaként fellépő kelet-zairei menekültválságot tárgyalom. A menekültáradat felborította Észak- és Dél-Kivu törékeny egyensúlyát és végzetes következményekkel járt az egész afrikai Nagy Tavak régióra.

\footnotetext{
449 Ibid.

${ }^{450}$ articles.cnn.com: Amanpour: Looking back at Rwanda genocide, April 06, 2004 http://articles.cnn.com/2004-04-06/world/rwanda.amanpour_1_rwanda-genocide-hutu-extremistssomalia?_s=PM:WORLD, [2012.08.25.]
} 


\section{7.fejezet: Zaire - 1996}

A zairei atrocitások megértéséhez nélkülözhetetlen Zaire (majd 1997. május 17. után Kongói Demokratikus Köztársaság) Kivu régiójának történelmi háttere. Az ország keleti részén, a Ruandával határos terület neve Kivu, amely földrajzilag és a társadalmi felépítés szempontjából is két fő részre bontható: Észak és Dél-Kivura.

\section{5. ábra A Kongói Demokratikus Köztársaság térképe}

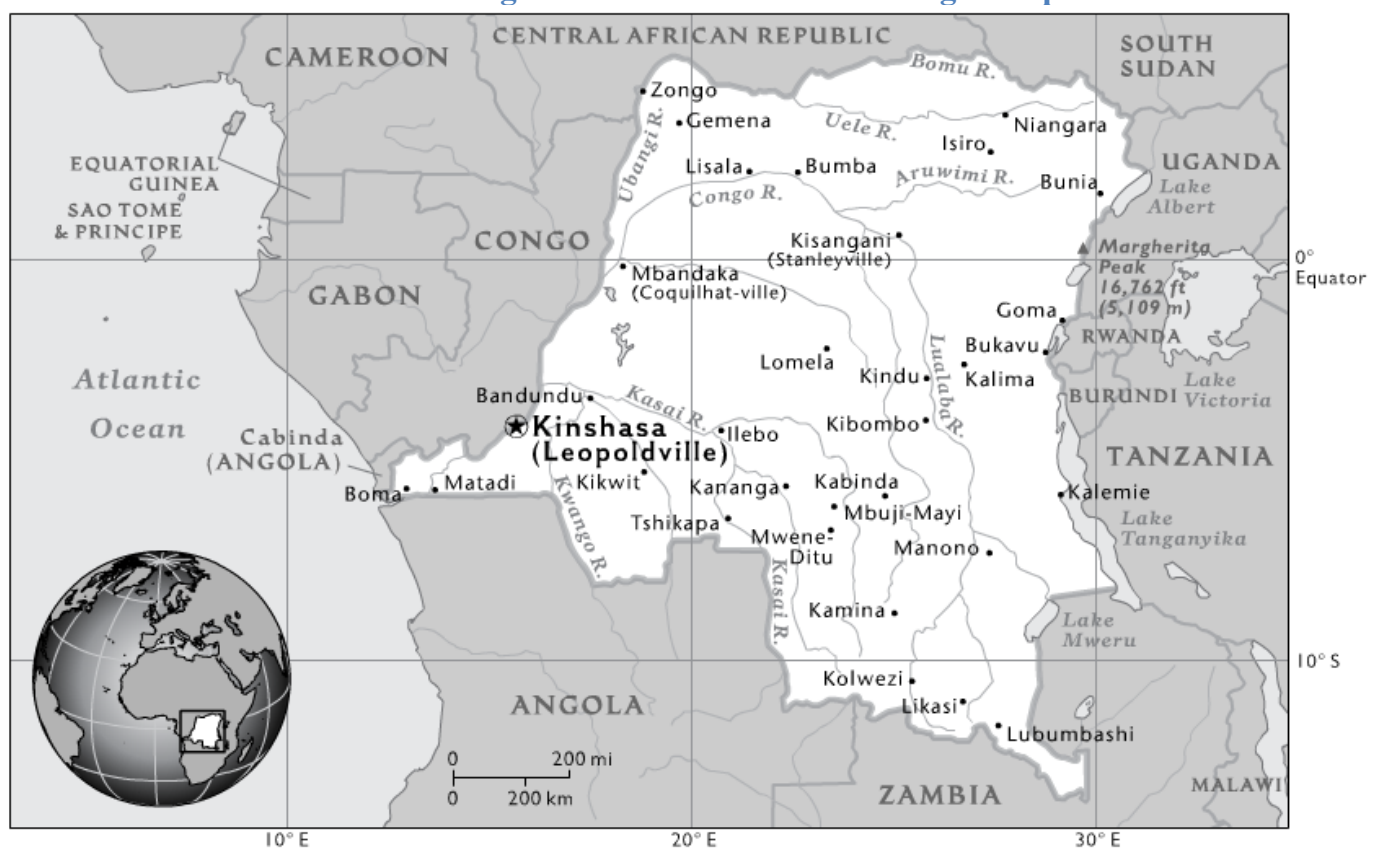

Forrás: National Georgraphic Education (2013):DRC

Az alábbi térképen jól látható, hogy Kivu területe jóval nagyobb, mint Ruandáé, másrészt megfigyelhetjük, hogy Kivu mennyire távol esik Zaire fővárosától, Kinshasától (ahol a kormány székel). ${ }^{452} \mathrm{~A}$ nagy távolság miatt a kinshasai kormány „keze nehezen ért el” a Ruandával határos országrészig.

A következő térképen Észak- és Dél-Kivu látható részletesebb felbontásban.

\footnotetext{
${ }^{452}$ A távolság Kinshasa és Goma (város Észak-Kivuban) között légvonalban több mint 1500 km
} 


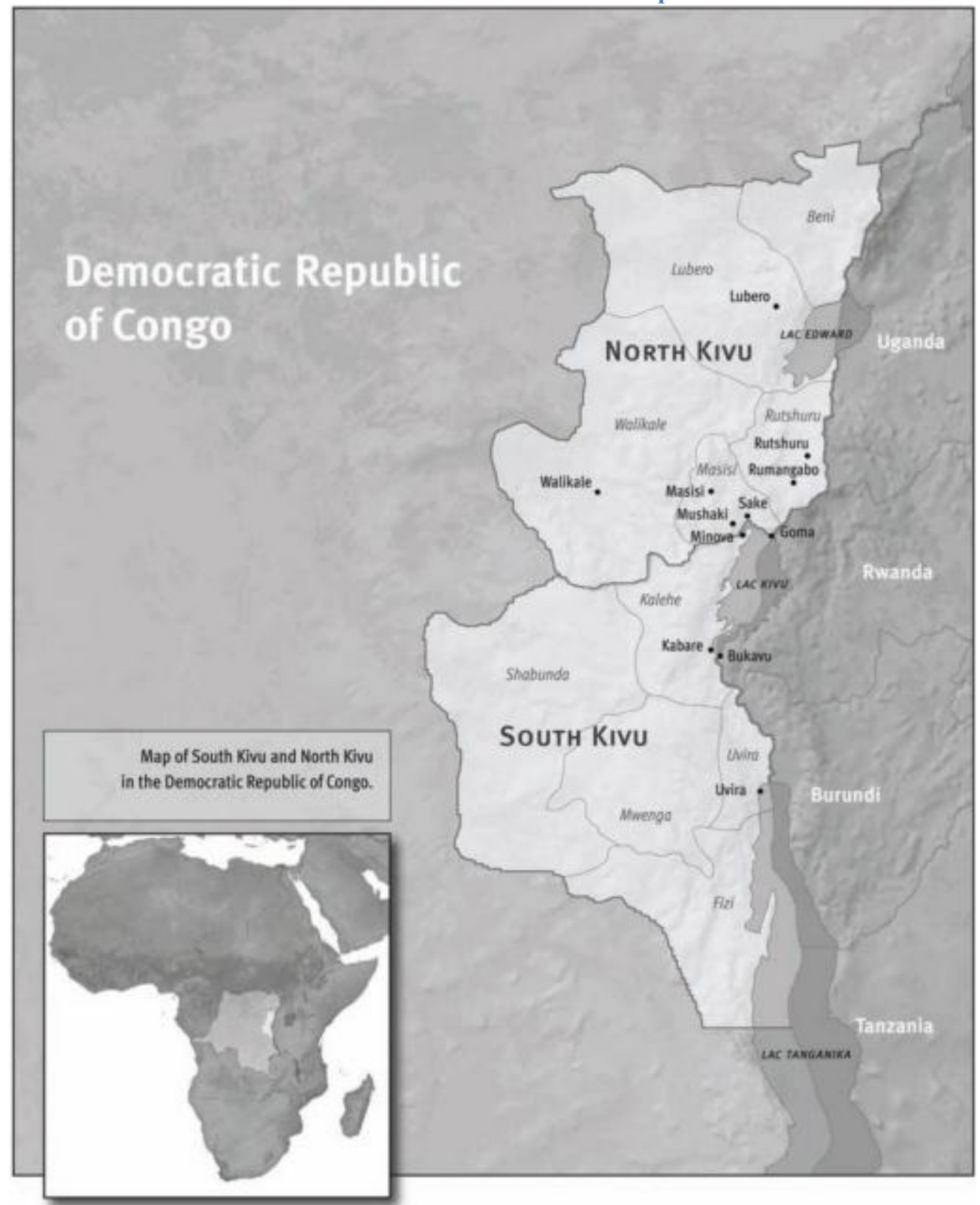

Forrás: HRW [2009]: Soldiers Who Rape, Commanders Who Condone: Sexual Violence and Military Reform in the Democratic Republic of Congo. New York: Human Rights Watch

\subsection{Történelmi háttér}

\subsection{1.Észak-Kivu}

Észak-Kivuban az 1990-es éveket megelőzően nagyon magas volt a termékenységi ráta, egyes helyeken közel négyszeresére növekedett a lakosságszám harminc éven belül (például Gomában). A területen hagyományosan éles harc folyik a (lakosok létszámához mérten) szűkösen rendelkezésre álló megmüvelhető földekért. 
Észak-Kivuban van egy ún. „őshonos” lakosság, és a kinyarwanda nyelven beszélők csoportja. A különféle kinyarwanda csoportok viszonylag békében éltek együtt az őslakosokkal 1937-ig, amikor a belga gyarmatosítók úgy döntöttek, hogy Kivuban tanulékony mezőgazdasági munkásokra van szükség, és segítették a ruandaiak bevándorlását. 1970-re összesen 335.000 ruandai bevándorló élt Zairéban, nagy részük Masisi környékén. ${ }^{453}$ A bevándoroltak között sok volt a tanult és jó anyagi helyzetü tutszi. ${ }^{454} \mathrm{Az}$ újonnan érkezők és a korábbi kinyarwanda lakosság körében egyfajta közös identitástudat alakult ki (ők voltak a banyarwandák), amelyet az őshonos lakosság nehezményezett, mivel saját helyzetüket Zaire nagyobb törzseihez képest már korábban is periférikusnak érezték.

A banyarwanda lakosság (amely Észak-Kivu lakosságának 40\%-át teszi ki) gyakran a helyi lakosság kárára igyekezett földhöz jutni, emiatt 1960-65-re erőteljes ellentétek alakultak ki a banyarwanda és őshonos lakosság közt Észak-Kivuban. Bár az ekkoriban dúló első polgárháború Észak-Kivut nem érintette közvetlenül, a háborús hangulat mégis remek lehetőséget teremtett a helyi adminisztratív vezetőknek, hogy üldözzék az általuk idegennek tartott banyarwandákat és földjeiket illegálisan eltulajdonítsák. ${ }^{455}$

Mobutu elnököt mindez hidegen hagyta, a banyarwandák egyre nehezebb helyzetbe kerültek. Változás állt be 1967-ben, amikor Mobutu úgy döntött, helyet biztosít nekik a központi kormányban. Mobutunak szüksége volt egy manipulálható helyi népcsoportra, hogy uralmát az ő segítségükkel biztosítsa a Kinshasától távol eső országrészben. ${ }^{456}$ Jobbkezévé tette Barthélémy Bisengimana-t, egy ruandai tutszi menekültet. Ilyen erős „protektorátussal” számos kivui tutszi sikeres vállalkozást indított, és földszerző akciókat indított. Ezek a lépések tovább szították az őslakosok ellenérzéseit. Bár csak néhányan gazdagodtak meg, az egész banyarwanda közösség megítélése negatívba fordult. ${ }^{457}$

A földekért vívott harc mellett a másik kérdéses pont az állampolgárság volt. ${ }^{458}$ Bisengimana 1972-ben sikeresen elfogadtatott egy olyan állampolgársági törvényt,

\footnotetext{
${ }^{453}$ Mathieu, Paul and Tsongo, Mafikiri [1999] : Enjeux fonciers, deplacement de population et escalades conflictuelles (1930-1995) In: P. Mathieu and J. C. Willame (eds.), Conflits et guerres au Kivu et dans la région des grands lacs (Paris, 1999), 20-25.old.

${ }^{454}$ International Crisis Group [2007]: Congo: Bringing Peace to North Kivu. Crisis Group Africa Report $\mathrm{N}^{\circ} 133,31$ October 2007

${ }_{455}$ Prunier, Gérard [2009]: Africa's World War: Congo, the Rwandan Genocide, and the Making of a Continental Catastrophe. Oxford: Oxford University Press

${ }^{456}$ ICG [2007]

${ }^{457}$ Prunier [2009]

${ }^{458}$ Reyntjens, F., Marysse S. [1996]:Conflits au Kivu: antécédents et enjeux,7. Anvers, Centre d'étude de la région des Grands Lacs d'Afrique, décembre 1996.
} 
amelynek értelmében minden Ruandából származó személy, aki legalább 1960-tól Belga Kongó területén tartózkodott, automatikusan megkapja a zairei állampolgárságot. ${ }^{459}$ 1977-ben, Bisengimana bukása után nagy nyomás nehezedett a kormányra, hogy ezt a banyarwandákra nézve kedvező törvényt változtassa meg. 1981 ben új állampolgársági törvényt fogalmaztak meg, amely kevésbé egyértelmü kritériumokhoz kötötte az állampolgárság megszerzését, gyakorlatilag egyéni elbírálás döntött az egyes esetekben. (Sok ezer banyarwanda de jure elvesztette állampolgárságát). ${ }^{460}$ Ennek 1987-re már meg is lett az eredménye, mert az észak-kivui választókörzetben egyszerüen nem tudták megállapítani, hogy kik a szavazásra jogosultak. A bizonytalan állampolgársági helyzet hatására az őslakosok támadásokat indítottak a banyarwanda tulajdonban álló vállalkozások és földek megszerzéséért.

A földért folytatott kiéleződött küzdelem interetnikai szintre emelkedett és a növekvő feszültségek 1992-től kezdve súlyos atrocitásokhoz vezettek. 1993-ban fordult elő például, hogy Walikale mellett az Ntoto piacon nagyszámú hutu Banyarwandát öltek meg felfegyverzett öslakosok. A mészárlás ezután még napokig folytatódott, mintegy ezer áldozatot követelve. A bosszú nem váratott sokáig magára, a Banyarwandák is öldökölni kezdték az őslakosokat. ${ }^{461} 1993$ augusztusára már mintegy húszezer halálos áldozata volt az összetüzéseknek és 250.000 ember menekült el a lakhelyéről ÉszakKivuban. Maga Mobutu elnök is a helyszínre utazott, és a hírhedt Különleges Elnöki Gárdát (Division Spéciale Présidentielle) is bevetették a helyzet rendezése érdekében. ${ }^{462}$ 1994 februárjában törékeny béke született, ez azonban tiszavirág-életünek bizonyult, mivel öt hónappal később a ruandai menekülthullám érkezése teljes egészében felborította a korábbi erőviszonyokat a térségben.

\subsubsection{Dél-Kivu}

Az Észak-Kivuhoz hasonló földrajzi adottságokkal rendelkező Dél-Kivuban kisebb a népsürüség, a fölhiány nem olyan égető probléma.

\footnotetext{
${ }^{459}$ ICG [2007]

${ }^{460}$ UNHCR Publications [2000]: The State of The World's Refugees 2000: Fifty Years of Humanitarian Action. Chapter 10: The Rwandan genocide and its aftermath

461 Garreton R.[1996]:,Rapport sur la situation des droits de l'homme au Zaïre conformément à la résolution 1996/77 de la Commission des Droits de 1Homme. Addendum. Mission dans le Kivu septentrional , Nations unies, E/CN.4/1997/6/Add.1

${ }^{462}$ Prunier [2009]
} 
Ebben a térségben az őslakosok mellett kisebb számban a banyamulenge népesség telepedett le. A banyamulenge lakosság nagyrészt ruandai tutszi betelepülőkből álltt ${ }^{463}$ (voltak, akik a XVII. században érkeztek), akik Zaire területén marhatenyésztéssel foglalkoztak (3000 méter feletti lakhelyük a Ruzizi fennsíkon nem is tette volna lehetővé a földművelést). A Banyamulenge szó jelentése: „Mulenge (helység DélKivuban) népe". ${ }^{464}$ A banyamulenge nevet tudatosan választották a betelepülő tutszik az 1970-es években, mert el akarták kerülni a negatív konnotációjú banyarwanda megnevezést (akiket minden kivui őslakos idegen népcsoportként azonosított). ${ }^{465}$ DélKivuban a banyamulengék mindössze a lakosság 3-4 százalékát tették ki (mintegy 2,4 milliós összlakosság mellett). ${ }^{466}$

Az első zairei polgárháború idején 1965-ig kimaradtak a konfliktusból, azonban 1965-ben állataik védelmében a kormány oldalán belekeveredtek a harcokba. A szomszédos törzs (babembe) a felkelők oldalán álltak, így a banyamulengék harci aktivitása hosszú időre megmérgezte e két törzs kapcsolatait. ${ }^{467}$ Amikor Ruandában kitört a háború, az RPF sikerrel toborzott a banyamulengék köréből. Sok fiatal a babembe törzzsel kialakult feszült viszony miatt szeretett volna harci tapasztalatokat szerezni, mert a banyamulengék a fenyegetettség légkörében élték mindennapjaikat.

$\mathrm{Az}$ állampolgársági törvények változása a banyamulengék helyzetét is bizonytalanná tette 1981-től. Ez is veszélyeztette magántulajdonukat és szavazati jogukat, sokukat másodrendü állampolgárnak tekintették az őslakosok.

A fentiekből kitűnik, hogy Észak és Dél-Kivuban sem volt felhőtlen az őslakosok és a betelepült ruandaiak közötti kapcsolat. Így amikor az 1994-es népirtás közben és után elkezdtek Ruandából özönleni a menekültek, a szunnyadó ellentétek az elviselhetetlenségig fokozódtak.

\subsection{Menekültáradat}

1994 júliusában és augusztusában Észak-Kivu Goma nevü területére mintegy 850.000, Dél-Kivuban Bukavuba 332.000, míg az Uvira körzetbe 62.000 ruandai menekült

\footnotetext{
${ }^{463}$ Lemarchand, René [2009]:The Dynamics of Violence in Central Africa. Philadelphia: University of Pennsylvania Press

${ }^{464}$ Mamdani, Mahmoud (2001). When Victims Become Killers: Colonialism, Nativism, and the Genocide in Rwanda. Princeton, NJ: Princeton University Press, 248-249.o

${ }^{465}$ Prunier [2009]

${ }^{466}$ Ibid.,

${ }^{467}$ Prunier [2009]
} 
érkezett (Uvirában ráadásul már volt 255.000 burundi menekült, akik Burundiból 1993 után érkeztek). ${ }^{468}$

Már maguk a számok is hatalmasak, de ezekkel a menekültekkel a szokásos (élelmezési, higiéniai, stb.) problémákon kívül más gondok is voltak.

Igaz, hogy az érkezők nagy része ú.n. bona fide (jóhiszemű) menekült volt. A menekültáradattal azonban az országba érkezett a ruandai tutszik elleni népirtás elkövetőinek nagy része is. Nekik egészen más céljaik voltak, mint a klasszikus értelemben vett menekülteknek: Zairéban akarták berendezni új katonai bázisukat, ahonnan gerillatámadásokat hajthatnak végre az új kigali kormány ellen. A ruandai menekülteket csak eszköznek tekintették, amely segítségükre lehet a Ruanda visszaszerzéséért folytatott harcban.

A menekültek önjelölt és felfegyverzett vezetői egész menekülttáborokat tartottak uralmuk alatt. Parancsaik hatására maguk a menekültek sem úgy viselkedtek, mint egy idegen ország ideiglenesen befogadott emberei, hanem mint a hódítók: engedély nélkül vágták ki a fákat, marhát loptak a helyi lakosságtól, károsították a termést, illegális úttorlaszokat állítottak fel.

A menekülttáborokban a közigazgatást szinte teljes mértékben ruandai mintára alakították ki a menekültekkel együtt beszivárgó népirtó rezsim vezetői. ${ }^{469} \mathrm{~A}$ menekülttáborok szervezettsége felért egy jól müködő államéval. A volt ruandai kormányerők és Interahamwe milíciák adót vetettek ki, amelyet a segélyszervezetek dolgozóinak is meg kellett fizetni, ha tevékenykedni akartak a tábor területén. Az ENSZ Menekültügyi Főbiztossága és számos nemzetközi szervezet nemcsak adózás tekintetében, hanem számos más téren is kénytelen volt együttmüködni velük: a segélyszállítmányok elosztása, iskoláztatási és egészségügyi kérdések sem dőlhettek el a népirtó rezsim vezetőinek jóváhagyása nélkül. ${ }^{470} \mathrm{~A}$ táborokban uralkodó rendszer és a korábbi elkövetőkkel való kényszerü együttműködés annyira felháborította a francia Orvosok Határok Nélkül (Médecins Sans Frontières) dolgozóit, hogy kivonultak a menekülttáborokból. ${ }^{471}$

A korábbi ruandai kormány és az Interahamwe katonái a nemzetközi szervezetek dolgozóinak szeme előtt tartottak hadgyakorlatokat, súlyosan megbüntették azokat, akik

\footnotetext{
${ }^{468}$ UNHCR [2000]

${ }^{469}$ Szabó Loránd [2008]: Kongói kaleidoszkóp 1998-2008: a hatalmi erőtér változásai. Külügyi Szemle, 2008. tél

${ }^{470}$ UNHCR Publications [2000]: The State of The World's Refugees 2000: Fifty Years of Humanitarian Action. Chapter 10: The Rwandan genocide and its aftermath

${ }^{471}$ Prunier [2009]
} 
ellentmondtak nekik. Gyilkosságok, fenyegetések, verekedések mindennapos jelenségekké váltak.

A menekülttáborok vezetése azt is mindenáron meg akarta akadályozni, hogy a menekültek hazatérjenek Ruandába, hiszen így saját „bázisukat” vesztették volna el. Aki mégis a hazatérésről beszélt, az életét kockáztatta. A volt FAR és Interahamweharcosok igyekeztek újra felfegyverkezni és végső céljuk Ruanda visszafoglalása volt.

A helyi hutukkal szövetségre lépve a Kivuban élö öslakosok elleni harcba is belekeveredtek. Ilyen módon sikerült valamennyire beilleszkedniük a kivui társadalomba és abban kezdtek el reménykedni, hogy kialakíthatnak egy állandó bázist, ahonnan Ruandáért harcolnak. Ha pedig Ruanda visszaszerzése nem is sikerül, Észak és Dél-Kivuban kialakíthatnak egy „új Ruandát”. ${ }^{472}$

Ráadásul ezek a felfegyverzett harcosok, a burundi menekültek jelenléte és a burundi kormány ellen harcoló gerillák dél-kivui bázisainak közelsége miatt fokozatosan a burundi konfliktusba is belekeveredtek. A konfliktusok nemzetköziesedése fokozatosan aláásta az egész afrikai Nagy Tavak régió biztonságát.

A menekültek jelenléte rendkívül súlyos szociális feszültségeket keltett és az ökológiai katasztrófa szélére sodorta Észak- és Dél-Kivut. Zaire elnöke, Mobutu kulcsfontosságú szerepet játszott abban, hogy a problémák csak súlyosbodtak. Mobutu ugyanis a ruandai menekültek révén igyekezett elérni, hogy újra szavahihetővé váljon a nemzetközi közösség szemében. Ezért későbbre csúsztatta a menekültek elüzésének céldátumát, majd beleegyezett, hogy eltekint az erőszakos megoldástól.

Mivel Mobutu a ruandai kormányt régi ellenségének, ${ }^{473}$ az ugandai Musevenirezsimnek a meghosszabbításaként érzékelte, szemet hunyt az új kigali rezsim elleni gerillatámadások fölött és a kivui helyi politika befolyásolására igyekezett felhasználni a menekültek jelenlétét. De kettős játékot játszva nemcsak a hutu szélsőségesek ruandai gerillatámadásait türte el, hanem aktívan támogatta a helyi kivui törzseket, akik a menekültek elüzését tűzték ki célul.

A regionális biztonsági helyzet kezdett aggasztóvá válni. 1995 októberében minden addiginál hevesebb összecsapások kezdődtek Észak-Kivuban. A hutuk a volt ruandai hadsereg és Interahamwe tagjainak vezetésével tömegesen a helyi tutszikra támadtak, akik kétségbeesésükben Ruandába menekültek. 1996 februárjára már mintegy 37.000

\footnotetext{
472 Ibid.

473 Adelman, Howard, Suhrke, Astrid [2000]: The Path of a Genocide: The Rwanda Crisis from Uganda to Zaire, Transaction Publishers, 338.old.
} 
tutszi menekült Zairéból Ruandába, közülük sokan egész életüket Zairéban élték le, mások még az 1959-es vérengzések elöl menekültek az akkor Belga Kongó területére. Tehát sok menekült zairei állampolgár volt, míg mások ruandai állampolgárok voltak, akik most tulajdonképp „,hazamenekültek”. Ennek ellenére az RPF egységesen kezelte a menekülteket és menekülttáborokat állítatott fel a zairei határ mentén.

A helyzet Dél-Kivuban sem alakult kedvezőbben. A dél-kivui helyi törzsek ellenségesen tekintettek a banyamulengékre. Felemlegették, hogy az 1981-es törvény értelmében zairei állampolgárságuk és így tulajdonjoguk megkérdőjelezhető. A hangulat egyre ellenségesebbé vált, szorult a hurok a banyamulengék körül. ${ }^{474}$ Ezt ők maguk is érezték, és igyekeztek fegyverekhez jutni és támogatást szerezni. Kigali juttatott is nekik fegyverszállítmányokat, és katonai segítséget is nyújtott. Míg a banyamulengék egy része a harcot választotta, másik része Ruanda felé menekült.

\subsection{A burundi politikai háttér}

Ruanda egyre növekvő aggodalommal figyelte északi szomszédjának sorsát is. Burundi már Melchior Ndadaye (hivatalban 1993. július 10-től 1993.október 21-ig) elnök 1993. októberi meggyilkolása óta forrongott. Melchior Ndadaye képviselte a mérsékelt hutukat, akik a tutszikkal együtt akartak kormányozni. Meggyilkolása a születő interetnikai konszenzus halálát is jelentette ${ }^{475}$ és ismét előtérbe kerültek a hutu és tutszi radikális eszmék és követőik. Az elnök meggyilkolása után előbb tutszi-, majd hutuellenes pogromok kezdődtek.

A kudarcba fulladt puccs (amelynek nem sikerült romba döntenie a mérsékelt hutu kormányt) amely a gyilkosságot eredményezte, kikezdte az egész államszervezetet. A hadsereget, mert nem volt világos, hogy kik álltak a puccsot kitervelők mellett és kik ellenük. A közhivatalnokok szintén gyanakodva tekintettek egymásra, hiszen sok hivatalnokot a FRODEBU (Front pour la Démocratie au Burundi) nevezett ki, és ezt a szervezetet vádolták azzal, hogy az elnök meggyilkolása utáni tutsziellenes pogromokat kitervelte. Ennek az lett az eredménye, hogy a tutszi többségű hadsereg folyamatosan aláásta a FRODEBU által dominált közigazgatást. ${ }^{476}$

\footnotetext{
${ }^{474}$ Vlassenroot, Koen [2002]: Citizenship, Identity Formation \& Conflict in South Kivu: The Case of the Banyamulenge, Review of African Political Economy, Vol.29 No.93/94 (Sep/Dec 2002), 499-515.old.

${ }^{475}$ Lemarchand, René [1996]: Burundi: Ethnic conflict and genocide. , Cambridge University Press, Preface, xiii. old

${ }^{476}$ Prunier [2009]
} 
A tutszi civil szervezetek szélsőségesei mindenáron meg akarták buktatni a hutu dominanciájú kormányt, és ennek érdekében demonstrációkat szerveztek, míg a hutu szélsőségesek is mozgolódtak: voltak köztük nyíltan tutsziellenes rasszisták, míg mérsékeltebbek is. A gerilla akciók intenzitása 1994-ben fokozatosan nőtt.

1994. április 6-án, amikor Ruanda elnöke meghalt a felrobbantott repülögépen, a gépen utazó Cyprien Ntaryamira (Melchior Ndadayét Cyprien Ntaryamira követte az elnöki székben), Burundi elnöke is életét vesztette a merényletben. ${ }^{477}$ Burundiban azonban nem volt olyan végzetes következménye a merényletnek, mint Ruandában. Még a hutu és a tutszi oldalon is sok mérsékelt politikus „tartotta a frontot”, illetve sem a hutuk, sem a tutszik nem terveltek szisztematikus népirtást, és a szükséges eszközök sem álltak rendelkezésre a megvalósításhoz. Szervezett népirtás helyett azonban folyamatosak voltak az atrocitások: fegyveres támadások az utakon, piaci lövöldözések, robbantások a szent helyeken, buszmegállókban. Az állandósult erőszak miatt a lakosság folyamatos félelemben élt. Valamilyen megoldásra és vezetőre szükség volt.

Anatole Kanyenkiko, aki már 1993 óta miniszterelnök volt, megpróbált úrrá lenni a káoszon és igyekezett minden érdekcsoportnak megadni a megfelelő képviseletet. 1994. szeptember 12-én hosszas tárgyalások után sikerült aláírni egy ígéretesnek tünő egyezményt, amely a helyzet konszolidálódásával kecsegtetett. A tutszi szélsőségesek azonban röviddel az egyezmény aláírása után újrakezdték a gerilla hadviselést: sztrájkokat szerveztek, akadályozták a hutu képviselők kinevezését, saját céljaik elérésére manipulálták a tutszi többségü igazságszolgáltatást.

Mivel az erőszak az 1994. szeptemberi egyezmény után sem ért véget, Kanyenkiko 1995 elején lemondott. ${ }^{478} \mathrm{Az}$ ország lassan, de biztosan egyre mélyebbre süllyedt az anarchiába. A hutuk és tutszik nem tudtak békés modus vivendit találni. Lassan két részre szakadt az ország: mindkét etnikai csoportnak kialakultak a „bázisai” az ország nagyobb városaiban: a hutuk bástyája lett Kamenge, Cibitoke, Kinama és Gasenyi, míg a tutszik inkább Musaga, Buyenzi és Ngarara városaiba húzódtak. A főváros, Bujumbura csatatérré vált.

1996 elején a nemzetközi közösség már újabb népirtástól tartott. A helyzet olyannyira feszültté vált, hogy Sylvestre Ntibantunganya (aki Cyprien Ntaryamira halála után vette át az elnöki posztot) elnök 1996. június 25-26-án az arushai regionális

\footnotetext{
${ }^{477}$ Szabó [2008]

${ }^{478}$ Ndarusigiye, Mevin, Mayoya, Marie [2000]: Burundi: when the pie is too small: handbook of ethnic conflicts and resource management, valamint Mwakikagile, Godfrey [2012]: Identity Politics and Ethnic Conflicts in Rwanda and Burundi: A Comparative Study, Intercontinental Books
} 
csúcson katonai beavatkozásra kérte a nemzetközi közösség jelenlévő képviselőit, hogy a rend és biztonság legalább valamennyire helyreálljon az országban. ${ }^{479}$

Ebben a rendkívül feszült helyzetben a tutszi közösség puccsot hajtott végre. A tutszi származású Pierre Buyoya, ${ }^{480}$ aki 1987-től 1993-ig egyszer már volt Burundi elnöke, átvette az ország vezetését. A tutszik így megdöntötték az 1993 júniusában hatalomra került mérsékelt hutu vezetést, valamint megállították az országot az anarchia útján. Ruanda számára kedvező változást jelentett ez a fordulat. ${ }^{481}$

Kagame tisztában volt vele, hogy ha a radikális hutuk kerültek volna hatalomra, legalább félmillió tutszi menekült érkezett volna Ruandába. ${ }^{482}$ Ráadásul Burundi kitűnő új bázist és támogatást jelentett volna a volt ruandai kormányerőknek és Interahamwe milíciáknak.

Az ENSZ 1996. augusztus 30-án ultimátumot adott Burundi új elnökének, amelynek értelmében az ország többségét alkotó hutukat is be kell vonni a hatalomba és meg kell állapodni a hatalommegosztásról a két fő etnikai csoport között. A szélsőséges gerillacsoportok továbbra is jelen voltak Burundiban: az ultimátum értelmében az új elnöknek két hónapon belül tárgyalnia kellett a felkelőkkel. ${ }^{483}$

\subsection{Ruandai katonai támadás}

A zairei beavatkozás Kagame gondolatvilágát követve több szempontból is kezdett elkerülhetetlenné válni. Egyrészt Ruanda nyugati határa mentén militarizált menekülttáborok sorakoztak, ahol fegyverkezett a Ruandából nagy nehezen elüldözött ellenség. ${ }^{484}$

Másrészt további bizonytalansági tényezőt jelentett, hogy Burundiban nem rendeződött megnyugtatóan a helyzet. A mérsékelt hutuk nem tudták megoldani az anarchiába süllyedő ország problémáit, az 1996 nyarán hatalomra került Pierre Buyoya vezette tutszi kormány pedig egyelőre nem tudta megoldani a nemzetközi és helyi közösség számára is elfogadható hatalommegosztást. ${ }^{485}$ Továbbra is fennállt a veszélye

\footnotetext{
${ }^{479}$ Prunier [2009]

${ }^{480}$ Robert Krueger (Burundi amerikai nagykövete) 2007-es From Bloodshed to Hope c. könyvében azzal vádolta meg Pierre Buyoyát, hogy ő rendelte el Melchior Ndadaye meggyilkolását. Krueger, Robert és Krueger, Kathleen Tobin [2007]: From Bloodshed to Hope in Burundi. University of Texas Press

${ }^{481}$ Watt, Nigel [2008]: Burundi: Biography of a Small African Country, Columbia University Press

482 Prunier [2009]

${ }^{483}$ Prunier [2009]

${ }^{484}$ Tanner, Fred és Stedman, S.J. [2003]: Refugee Manipulation. The Brookings Institution, 104.old.

485 Presidents of Burundi: Melchior Ndadaye, Pierre Nkurunziza, Pierre Buyoya, Domitien Ndayizeye, Cyprien Ntaryamira, Michel Micombero, General Books, 2010
} 
a radikális hutu hatalomátvételnek. Kigali pedig nem engedhette meg magának, hogy a lakosságszáma még a burundi menekültekkel is növekedjen, mert Kagame rendszerének alapjai rendülhettek volna meg. Így is nehézségeket okozott, hogy mindenkinek jusson föld és megélhetés. ${ }^{486}$

Harmadrészt Kagame beavatkozási szándékát egy általánosabb, Mobutu megbuktatását célzó transzafrikai terv is befolyásolta. (Museveni ugandai elnök már 1994 novemberében Mobutu-ellenes találkozót hívott össze Kampalában, Mobutu megbuktatásának megbeszélésére.) 1996-ban azonban a Mobutu megbuktatására irányuló tervek még nem kristályosodtak ki. ${ }^{487}$ Paul Kagame nem engedhette meg magának, hogy erre tovább várjon, és ki akarta használni a róla kialakult pozitív képet (a népirtást megállító RPF-parancsnok).

A nemzetközi közösség emlékezetében még élénken élt a ruandai népirtás emléke. A Biztonsági Tanács tagjai büntudatot éreztek az 1994-ben tanúsított tehetetlenségük miatt, és emiatt tartózkodtak attól, hogy a népirtást megállító RPF parancsnokát, vagy Ruanda új kormányát kritizálják. A ruandai kormány és Paul Kagame tisztában volt ezzel és maximálisan kihasználta a nemzetközi közösség „elnéző” hozzáállását. ${ }^{488}$

Kagame 1996 szeptemberére időzítette a katonai támadás kezdetét. Már 1996. július elejétől kezdve banyamulenge RPF-veteránok kezdtek átszivárogni a határon Ruandából Dél-Kivuba, és ott a számukra előre elrejtett fegyvereket megkeresve csatlakoztak a helyi banyamulenge milíciákhoz, és szeptember 22-én Bukavut össztüz alá vették. Így elterelték a zairei hadsereg figyelmét, és még több ruandai katona kelt át a határon.

Közben Kigali azt hangoztatta, hogy semmi köze ahhoz, ami Dél-Kivuban folyik. A ruandai sajtó azonban a támadás esélyeit és mögöttes indítékait latolgatva megemlítette, hogy Ruandának esetleg érdekében állna Észak és Dél-Kivu annektálása, vagy egy önálló Kivuval való együttműködés. Közben Bizimungu, a ruandai kormány elnöke egy 1996. október 3-i sajtótájékoztatón térkép segítségével mutatta be, hogy Észak-Kivu és Dél-Kivu bizonyos részei korábban a ruandai királyság integráns részét képezték. Majd a következőképpen fogalmazott: „Ha Zaire visszaadja Ruanda lakosságát, akkor azt a földet is adja vissza, amelyen ezek az emberek élnek."

\footnotetext{
${ }^{486}$ Uvin, Peter [1998]: Aiding Violence: The Development Enterprise in Rwanda, Kumarian Press. The Role of Ecological Scarcity, 199.old.

${ }^{487}$ Prunier [2009]

${ }^{488}$ Rombouts, Heidy [2004]: Victim Organisations and the Politics of Reparation: A Case Study on Rwanda, Intersentiua Publishers, 164. old.
} 
A banyamulenge milíciák, ruandai hadsereg és a zairei kormányerök közötti harcok közben folytatódtak. Nem sokkal a szeptemberi támadás után az eseményekkel szimpatizáló és Mobutu megbuktatásáért küzdő új zairei politikai mozgalom jelentette be megalakulását: a Demokratikus Erők Szövetsége Kongó-Zaire Felszabadításáért (Alliance des Forces Démocratiques pour la Libération du Congo-Zaire, AFDL). ${ }^{489}$ Kagaménak nagyon jól jött az, hogy egy helyi felkelő csoport (AFDL) álcája mögé bújva spontán banyamulenge felkelésnek tüntethette fel a menekülttáborok elleni támadássorozatot. $^{490}$

A harcok fő célja az új ruandai vezetés számára katonai kockázatot rejtő határ menti menekülttáborok felszámolása volt. Az akciók brutalitása csak sokkal később vált világossá és bizonyítottá. Míg a nemzetközi közösség azt hitte és remélte, hogy a ruandai erők legalább minimális mértékben igyekeznek szétválasztani a felfegyverzett és militarizált „menekülteket” a civilektől.

Október 17-én az RPA-Banyamulenge erők újabb, Uvira melletti menekülttáborokat támadott meg. Néhány nappal később már 250.000 menekült szóródott szét a szélrózsa minden irányába. ${ }^{491}$

Az alábbi térképen a menekülttáborokból szétkergetett menekültek útvonala látható pirossal megjelölve:

\footnotetext{
${ }^{489}$ Benkes Mihály István [2004]: A kongói válság történeti gyökerei - a mobutizmus politikai hagyatéka. I. évfolyam 2004/1

${ }^{490}$ Prunier [2009]

${ }^{491}$ Arnold, Guy[2009]: The A to Z of Civil Wars in Africa, 415.old. Scarecrow Press
} 
7. ábra A menekülttáborokból szétkergetett menekültek útvonala (DRC)

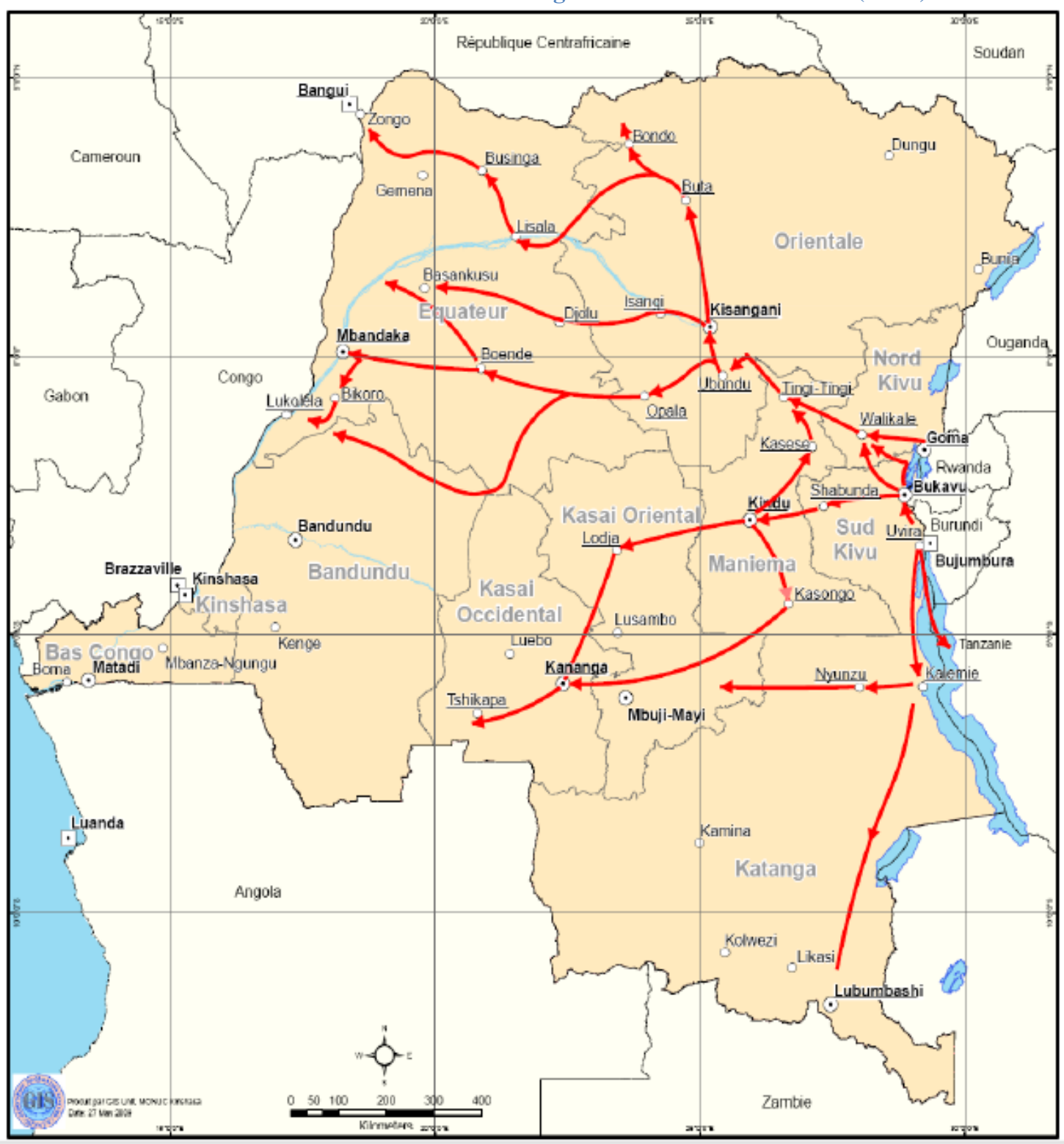

Forrás: DRC: Mapping Human Rights Violations 1993-2003, 79.old.

Közben október 22-én az észak-kivui Kibumba és Katale menekülttáborokat is tűz alá vették. $^{492}$

Ekkor már kívülállók számára is kezdett nyilvánvalóvá válni, hogy nem a banyamulenge milíciák szokásos „védekező” akciójáról van szó. A kivui válságban részes országok külügyminisztériumainak kommunikációja a médiával meglehetősen félrevezető volt a válság kezdetétől. Amikor 1996 őszén a menekülteket megtámadták a zairei felkelők, a ruandai kormányerők és a burundi FAB katonái, Kigali természetesen cáfolta, hogy bármi köze lenne a kivui harcokhoz. A ruandai rádió 1996. november 3-án

492 UNHCR [2010]: DRC: Mapping Human Rights Violations 1993-2003 http://www.ohchr.org /Documents/Countries/ZR/DRC_MAPPING_REPORT_FINAL_EN.pdf, 93.old. 
kijelentette: „A külföldi média továbbra is belekeveri Ruandát a kelet-zairei válságba. [...] Azonban hangsúlyoznunk kell, hogy a konfliktusban [...] csak zairei lakosok harcolnak zaireiek ellen." ${ }^{493}$ Kigali külügyminisztere, Anastase Gasana továbbra is azt hangoztatta, hogy a zairei krízis csak Zairéra tartozik és semmilyen értelemben nem érinti Ruandát. ${ }^{494}$

Az AFDL, RPA, és a burundi hadsereg megtámadta a ruandai és burundi hutu menekülttáborokat Uvira, Bukavu és Goma környékén. Több százezer ruandai menekült visszatért Ruandába ${ }^{495}$, de több százezren Zaire belseje felé indultak, Walikale és Shabunda felé. ${ }^{496}$ Ebben a második csoportban voltak a korábbi kormányhadsereg és az Interahamwe katonái. A Zaire szívébe menekülőket hónapokon keresztül üldözték az AFDL és RPA katonái. Szívós rendszerességgel rombolták le a sebtében felállított táborokat útközben, és üldözték azokat, akik a menekültek segítségére siettek volna.

1996 decemberétől Mobutu katonái ellentámadásba lendültek, de nem volt elegendő idejük a szétesett hadsereg és hadmozdulatok megszervezésére, így kezdeményezésük kudarcra volt ítélve az AFDL/RPA viszonylag jól felszerelt és céltudatos seregeivel szemben.

Ahogy a behatolók közeledtek a fövároshoz, Mobutu kénytelen volt külföldre menekülni. 1997. május közepén a lázadók bevették Kinshasát. Az AFDL vezetője, Laurent-Désiré Kabila köztársasági elnökké neveztette ki magát és az ország nevét Kongói Demokratikus Köztársaságra (a továbbiakban: Kongó) változtatta. 497

Időközben az AFDL és RPA csapatok folytatták a menekültek üldözését Kongó egész területén. A volt Interahamwe milícia tagjai, valamint a korábbi ruandai kormány katonái gyakran emberi pajzsokként használták az ú.n. bona fide (jóhiszemű) menekülteket. Ezek a szedett-vedett, menekülö militáns csoportok gyakran a helyi lakosság ellen is súlyos atrocitásokat követtek el útközben, raboltak, fosztogattak.

A szövetséges katonák (AFDL/RPA és néha együttmüködő burundi kormánykatonák egységei) útközben ellenőrző pontokat állítottak fel. Ezeknél a pontoknál az akcentus, ruházat vagy arc- és testfelépítés alapján ruandai vagy burundi hutunak ítélt embereket elválasztották a többiektől azzal az ürüggyel, hogy visszaviszik

\footnotetext{
493 Ibid.

${ }^{494}$ McKinley, James Jr: As Fighting in Zaire Spreads, Rwanda Rules Out Talks. The New York Times, October 29, 1996

495 A pontos számokat szinte lehetetlen megbecsülni, de valószínüleg mintegy 500.000 menekült tért vissza Ruandába

${ }^{496}$ UNHCR [2010], 70.old.

${ }^{497}$ Prunier [2009]
} 
őket a származási országukba. Ehelyett azonban általában kivégezték őket egy félreeső helyen.

Összességében mi lett a menekültek sorsa? Akik Kivuból elmenekültek Kongó belseje felé, azok északnyugatnak indultak (mintegy 350.000 ember), vagy délnek Shabunda felé (150.000 ember). Mintegy 100.000 menekült ott maradt Kivuban, és Virunga-hegység erdeiben rejtőzött el, ${ }^{498}$ vagy a kongói hutu lakosság között próbált meg elvegyülni. Legrosszabb sorsra azok jutottak, akik nem tudtak elrejtőzni, mert a támadók valósággal vadásztak rájuk, meg sem próbálva elkülöníteni a népirtásért felelősöket a menekültektől. ${ }^{499}$

A menekültek legnagyobb csoportja eredetileg kelet felé tartott, azonban később Lobutu felé indult, mert a menekültek közé vegyült Interahamwe harcosok többükkel is végeztek, amikor ragaszkodtak a keleti irányhoz.

A Shabunda és Lobutu környékén letelepedők néhány hónapnyi lélegzetvételhez jutottak, amíg a szövetséges erők kialakították kongói bázisaikat és politikailag, valamint katonailag is igyekeztek megerösödni. 1997 elején azonban tovább folytatták útjukat nyugat felé, és az útjukba eső menekülttáborokat megtámadták. A menekültek szétszóródtak a szélrózsa minden irányába, a fegyveresek azonban autókkal közlekedtek, így az esetek nagy többségében utolérték őket. A fiatal férfiakat elválasztották a többiektől, lelőtték, majd az életben maradtakat visszaterelték Bukavu (kelet) felé. ${ }^{500}$

Azok, akik elmenekültek, hosszú vándorútra keltek, és gyakran egészen Angola határáig jutottak. Útközben egész végig atrocitásoknak voltak kitéve. A szövetséges erők a kifáradt és éhes menekültekhez előre engedték a humanitárius szervezeteket. Amikor a rejtőzködők próbálták megközelítenia segélyszervezetek dolgozóit, általábana katonaság is előkerült, és megölte őket. ${ }^{501}$ Sok civil szervezet nem is vállalta ezt a munkát, mert azt érezte, hogy jelenléte csak további veszélyforrás a menekültekre nézve.

A Zaire, majd Kongó egész területén keletről nyugatra tartó hajsza során tízezrek haltak meg az élelemhiány és az egészségügyi ellátás teljes hiánya miatt, tízezreket megöltek az AFDL-banyamulenge-ruandai csapatok. Az áldozatok számára különböző

\footnotetext{
${ }^{498}$ UNHCR [2010], 95.old.

${ }^{499}$ Prunier [2009]

500 Ibid.

${ }^{501}$ UNHCR Publications [2000]: The State of The World's Refugees 2000: Fifty Years of Humanitarian Action. Chapter 10: The Rwandan genocide and its aftermath
} 
források eltérő becsléseket adnak, Garreton és Kisangani ${ }^{502}$ elemzéseit alapul véve valószínüleg mintegy 200.000 menekült veszett oda.

\subsection{A nemzetközi közösség}

A nemzetközi közösség az 1996-ban kezdődő, Zairéban zajló ruandai beavatkozás idején tétlenségével ismét cserbenhagyta az afrikai Nagy Tavak régió civil lakosságát. Sok kérdés merül fel a kelet-zairei atrocitások kapcsán, amelyek megválaszolása segíthet megérteni a nyugati világ passzivitását a menekültek helyzetének rendezésére. Vajon a nemzetközi közösség tisztában volt a Kelet-Zairéban kialakult menekültprobléma súlyosságával? Az alábbi elemzésben erre a kérdésre keressük a választ.

A témában több szakkönyv is megjelent, amelyek elérhetőek voltak az érdeklődő nyugati közönség számára. Ezekben a kötetekben általában ajánlásokat is megfogalmaztak az ENSZ, illetve a nemzetközi közösség számára. Kiemelendő PHILIPPE DE DORLODOT 1996-ban megjelentetett könyve: "Les réfugiés rwandais à Bukavu au Zaire. De nouveaux Palestiniens?”, amelynek már címe is árulkodó, hiszen azt sugallja, hogy a Kivuban rekedt menekültek a palesztin menekültekhez hasonló sorsra juthatnak. A könyv utóiratában FILIP REYNTJENS, a régió szakértője és a könyv írójával egybehangzóan arra a következtetésre jut, hogy a kikényszerített repatriálás elfogadhatatlan, az önkéntes visszatérés a Ruandában uralkodó viszonyok és a menekülteket uralmuk alatt tartó felfegyverzett, szélsőséges hutuk szándékai miatt elképzelhetetlen. Reyntjens ugyanakkor igyekszik a nemzetközi közösségnek is üzenni a könyv lapjain: figyelmeztet, hogy ha nem reagálnak a régióból hallatszó „segélykiáltásokra”, akkor „1994 eseményei csak egyszerü előjátékká válnak majd, és a legrosszabb még ezután következik”.

A konfliktus kezdete előtt mintegy két hónappal az ENSZ Biztonsági Tanácsának öt állandó tagja a fötitkártól kézhez kapott egy részletes és aggasztó jövőképet festő jelentést, amely részletesen tárgyalja a Zairéban rekedt ruandai menekültek helyzetét. A főtitkár a Biztonsági Tanács sürgősségi összehívását kérte és felhatalmazását arra, hogy kétezer katonából álló kontingenst küldjön Kivuba a segélyszállítmányok célba

\footnotetext{
${ }^{502}$ Emizet, Kisangani N.F. [2000]: The massacre of refugees in Congo: a case of UN peacekeeping failure and international law, The Journal of Modern African Studies,38,2, 163-202.oldal, Garreton, Oscar [1998]: L'impossible enquête, Le Monde diplomatique, 1998. január
} 
juttatásának zavartalansága és a harcoló felek szétválasztása érdekében. ${ }^{503}$ Ebből arra lehet következtetni, hogy a helyzet súlyosságát tehát már két hónappal a konfliktus kirobbanása előtt is érzékelte a nemzetközi közösség. ${ }^{504}$ Ugyanakkor nemzetközi civilés segélyszervezetek aktívan tevékenykedtek a menekülttáborokban, és a közvéleményt folyamatosan tájékoztatták az aktuális helyzetről.

A helyi megfigyelőktől is érkeztek figyelmeztetések: Christophe Munzihirwa, Bukavu püspöke az ENSZ menekültügyi főbiztosának 1995. október 6-án írt levelében kiemelte: „A menekültekből már nem kérnek Zairéban és úgy tünik, hogy Ruanda sem akarja, hogy visszatérjenek. Közép-Afrikában új palesztin népcsoport alakult, és ez a helyzet nagy valószínüséggel konfliktusokat fog okozni a határok mentén. A Nemzetközi Közösségnek tehát nyomást kellene gyakorolnia, hogy ennek az erőszaknak az eszkalációját megakadályozza és garantálja a menekültek biztonságos visszatérését." 505

Kigali többször is felszólította mind az ENSZ-t, mind a zairei vezetést arra, hogy válassza szét egymástól a fegyveres elemeket és a civil menekülteket a menekülttáborokon belül. ${ }^{506}$ Twagiramungu (aki névleg Ruanda elnöke volt 1995. augusztus 31-ig, habár a háttérből, alelnökként Paul Kagame irányította az eseményeket) kijelentette: „Megkértem az Egyesült Nemzetek Szervezetét, hogy válassza el a katonákat az igazi menekültektől. Ezt azonban nem brutálisan kellene végrehajtani, mert arra rosszul reagálnának a táborok lakói." ${ }^{, 507}$ A ruandai védelmi miniszter is egyetértett: „Nem látom be, hogy miért kell segélyezni a még mindig felfegyverzett milicistákat, akik embereket ölnek. [...] Ezeknek a bünöző csoportoknak az erejét túlbecsülik. Határozottan leszerelhetők és áthelyezhetők." ${ }^{\text {,508 }}$

Kagame maga is többször figyelmeztette az ENSZ eröit, a zairei kormányt, valamint az Amerikai Egyesült Államokat is, hogy cselekedjenek, mert ha nem, akkor ő teszi meg. 509

A menekültek közé keveredett, illetve őket vezető hutu szélsőségesek katonai aktivitása nem csökkent 1994 után. Kagame többszöri kérése ellenére sem az ENSZ,

\footnotetext{
${ }^{503}$ Organisation Interafricaine des Juristes: La crise humanitaire dans l'Est du Zaire, 1997, március

${ }^{504}$ Nouvel Observateur, 1996. november 14-20. Jean Daniel: Zaïre la faim fera le travail...

${ }^{505}$ Munzihirwa, Christophe [2007]: Lettere e appelli dal Congo, EMI (collana Vita di missione)

${ }^{506}$ Boutroue, Joel [1998] : Missed opportunities- The role of the international community in the return of the Rwandan refugees from Eastern Zaire, July 1994- December 1996, UNHCR Report

${ }^{507}$ Reuters, December 6, 1994.

${ }^{508}$ Security Council, statement, December 15, 1994

509 AP Enterprise: Questions raised on Congo slaughter, October 10, 2010 http://www.foxnews.com/world/2010/10/10/ap-enterprise-questions-raised-congo-slaughter/
} 
sem a nemzetközi közösség más tagjai, sem a zairei kormány nem tett érdemi lépéseket annak érdekében, hogy a felfegyverzett szélsőséges hutukat a fegyvertelen civilektől elválassza és a népirtás esetleges felelöseit a táborokban felkutassa.

A helyzet 1996-ra ismét robbanás közelivé vált. Ekkor Ruanda akcióba lépett.

\subsection{A beavatkozás mellett és ellen: Belgium, Franciaország és az USA álláspontja}

Amikor 1996 őszén végül megindultak a menekülttáborok felszámolását célzó akciók, a nemzetközi közösség tagjai már a támadások kezdetétől egyetértettek abban, hogy Zaire keleti részén be kell avatkozni. Nagyon eltértek azonban az álláspontok a beavatkozás jellegét és célját tekintve. Patrick Dupont ${ }^{510}$ az egyes álláspontok részletes elemzése után arra a következtetésre jutott, hogy két tábor állt egymással szemben.

Egyesek két speciális, különálló, megoldandó feladatot láttak: különválasztották a kivui háború által okozott humanitárius válságot és a menekültkérdést. Ezt az álláspontot követték általában a nemzetközi szervezetek, valamint többek között Franciaország, Spanyolország és Belgium.

Belgium hozzáállása külön kitérőt is érdemel, hiszen a terület Belgium gyarmata volt korábban, habár Mobutu-éra „külpolitikai ingamozgása”,511 révén Belgium szerepe jelentősen csökkent. A kilencvenes évekre azonban Belgium más formában ugyan, de továbbra is erőteljesen jelen volt Zairéban: részt vett az exporthitelezésben és beruházásokban, segélyezte a közszférát, katonai segítséget nyújtott. Patrick Dupont Belgium kelet-zairei krízis alatt tanúsított hozzáállását az „aktív semlegesség” kifejezéssel illeti, hiszen egyrészt támogatta egy közös nemzetközi humanitárius beavatkozás gondolatát, de ő maga egyetlen katonát sem ajánlott fel a célra. Diplomáciailag azonban végig aktív volt, európai szövetségesei figyelmét a válságra irányítva.

A „globalisták” szerint a háború miatti humanitárius válságot nem lehet különválasztani a menekültkérdéstől. Szerintük a menekültek jelenléte közvetlen okokozati összefüggésben áll a kivui harcokkal. Éppen ezért úgy gondolták, hogy egy humanitárius intervenciónak csak akkor lenne értelme, ha a menekültek hazatérésével végződne. Az Amerikai Egyesült Államok és Ruanda ilyen jellegű beavatkozást tudtak

\footnotetext{
${ }^{510}$ Dupont, Patrick [1996] : La communauté internationale face à la question de l'intervention humanitaire lors de la rébellion au Kivu (octobre-decembre 1996), In: http://www.ua.ac.be/objs/00110972.pdf

${ }^{511}$ Benkes Mihály István (2004): A kongói válság történeti gyökerei- a mobutizmus politikai hagyatéka Kül-Világ, 2004/1. http://epa.oszk.hu/00000/00039/00001/pdf/benkes.pdf
} 
csak elképzelni (illetve, ahogy a későbbiek során látni fogjuk, valójában ilyet sem). Számukra a kivui helyzet nem volt más, mint Zaire belső problémája, amelyet súlyosbít a ruandai menekültek jelenléte. Az 1996 őszén indult „összetűzések” kiváltó oka véleményük szerint azonban a zairei politikai vezetés rugalmatlansága a banyarwandák állampolgárságának kérdésében.

Az Amerikai Egyesült Államok nem volt hajlandó elismerni, hogy a kivui konfliktusban Ruandának is szerepe van. Azt az álláspontot védelmezték, amely szerint a zairei kormány a volt Interahamwe és az elöző ruandai kormány katonáival karöltve kulcsszerepet játszottak a konfliktus kiélezésében. Egy regionális vagy bilaterális konferencia vagy béketárgyalás megszervezésében sem hittek. Nem tulajdonítottak jelentőséget annak, hogy az általuk jogszerünek tartott „,banyamulenge felkelés” (ők így nevezték a kivui válságot) résztvevőinek Ruanda és Burundi katonai segítséget nyújtottak.

A legfontosabb szempont Amerika szemében az volt, hogy az afrikai Nagy Tavak régió stabilabbá váljon. Ebből a szempontból nézve a kivui konfliktust, a Kagamevezette beavatkozás hatására körvonalazódni látszott a megoldhatatlannak tartott középafrikai menekültkérdés gyors lezárása. Az alkalmazott módszerek másodlagosak voltak, és Washington csak utólag tiltakozott miattuk.

$\mathrm{Az}$ amerikai kormányt több tényező is visszatartotta attól, hogy aktívabban támogassa a nemzetközi beavatkozást. Az 1993-ban Szomáliában történtek hatására visszafogottan nyilatkozott a zairei nemzetközi misszió alapítása kapcsán. ${ }^{512}$ Bizonyos kormányzati szereplők támogatták Kagamét, még ha ezt nem is ismerték volna el nyilvánosan. A washingtoni döntéshozatal egyszerre több szinten is folyt, és ezek a különböző szintü döntéshozók gyakran nem értettek egyet egymással. Ennek eredménye egy általános elnéző hozzáállás lett Kagame akcióival szemben. George Joulwan, a NATO feje, amerikai ezredes, egyenesen „látnoknak” ${ }^{, 513}$ nevezte Kagamét.

A helyi AFDL-lel szövetségre lépett ruandai katonák és az FAB harcosai a franciák által támogatott Mobutu megdöntését is célul tüzték ki, ez pedig szintén Amerika érdekeit szolgálta. ${ }^{514}$

\footnotetext{
${ }^{512}$ Bassir-Pour, Afsane [1996]: Washington freine toujours l'envoi d'une force multinationale au Zaire, 1996. november 11. , Le Monde

${ }^{513}$ Pomfret, John [1997]: Rwandans Led Revolt in Congo, Washington Post, July 9, 1997

${ }^{514}$ A dolgozat terjedelmi korlátai miatt nem tárgyalom a Kivuban található ásványkincsek szerepét a konfliktusban, azonban megjegyzem, hogy Laurent-Désiré Kabila számos bányászati szerződést újratárgyalt bizonyos amerikai vállalatokkal, például az American Mineral Fields International-lel, és 1997. április 16-án mintegy egymilliárd dollár értékben szerződést írt alá az AMFI-val, amelyben
} 
Franciaország és Spanyolország már október 28-án, a Luxemburgban tartott minisztertanácsi EU-ülésen jelezte, hogy támogatja a humanitárius intervenciót KeletZairéban. Chirac és Aznar 5000 fös katonai alakulatot tartott szükségesnek, amelybe maguk is delegáltak volna katonákat, azzal a feltétellel, hogy az Egyesült Államok, afrikai és európai országok, valamint az ENSZ is küld csapatokat.

Franciaország többször is hangsúlyozta ez utóbbi feltétel fontosságát. Párizs tartott attól, hogy katonai intervenció esetén részvételét egyoldalúnak titulálják a nemzetközi közösség kritikusai. Ugyanakkor geopolitikai státuszának megőrzése érdekében érezte, hogy nem engedheti meg magának egy újabb befolyási övezet elvesztését az afrikai Nagy Tavak régióban, ahol már le kellett mondania Ruandáról. Mobutu elnökben Párizs saját szövetségesét látta, éppen ezért a Kabila-vezette AFDL-felkelők szúrták Franciaország szemét. Hatalomátvételük megakadályozása legalább olyan erőteljes motivációt jelentett az intervenció megvalósítása mellett, mint a menekültek sorsa miatt érzett aggodalom. Franciaország azonban csak nemzetközi felhatalmazással és nemzetközi részvétellel, a látszatot őrizve gondolt a beavatkozásra. ${ }^{515}$

Párizs igyekezett meggyőzni ${ }^{516}$ a nemzetközi közösség többi tagját arról, hogy a beavatkozásra a menekültek megmentése miatt feltétlenül szükség van, de a nyugati hatalmak többsége hezitált. ${ }^{517}$

Boutros Boutros-Ghali korábbi ENSZ-főtitkár regionális békekonferencia ötletét vetette fel októberben. Az ötletet támogatta az Európai Unió is, Franciaország és Belgium pedig sürgette Zairét és Ruandát, hogy üljenek tárgyalóasztalhoz.

\subsection{A nemzetközi misszió ötletének körvonalazódása, és megvalósulásának kudarca}

A nemzetközi civil- és segélyszervezetek is folyamatos nyomást gyakoroltak a nemzetközi közvéleményre a cselekvés érdekében. 1996. október 29-én Genfben rendkívüli ülést tartottak a francia és belga államtitkárok (Moreels és Emmanuelli) szervezésében, és a megbeszélés során körvonalazódott először, a konkrétumokat tekintve is, egy humanitárius erő Kelet-Zairéba küldése. A konferencián azt is

biztosította számára a kitermelési jogokat például Kivuban is. Mobutu az 1960-as években amerikai segítséggel került hatalomra Patrice Lumumba meggyilkolása révén, korrupt és elnyomó uralma azonban az 1990-es évekre diszkreditálta az amerikai politikai elit körében. 1993-ban az USA már megtagadta tőle a beutazáshoz szükséges vízumot.

${ }^{515}$ Le Nouvel Observateur, 1996. október 7-13. Le souvenir amer de Turquoise

${ }^{516}$ Libération, Zaire: le forcing français, 1996. november 7.

${ }_{517}$ Roberts, Andrews [1996]: Zaire: A Problem for France Alone, The Sunday Times, 1996. november 10 . 
egyeztették, hogy mely nemzetközi szervezet és ország hány katonával kívánja támogatni a kontingenst. Az Egyesült Államok szintén hajlandónak mutatkozott az aktív részvételre, és tájékozódásképpen Kelet-Zairéba küldte Richard Bogosiant. ${ }^{518} \mathrm{Az}$ Egyesült Királyság azonban kijelentette, hogy további részleteket szeretne megismerni, mielőtt dönt az ügyben. ${ }^{519}$

Közben 1996. november 5-én Nairobiban az afrikai Nagy Tavak régió országai (kivéve Zairét és Burundit), valamint az Afrikai Egységszervezet tagjai bejelentették a Biztonsági Tanácsnak, hogy sürgős intézkedésekre van szükség, és megfontolandó akár a katonai beavatkozás is, amelyben afrikai országok is részt vennének. ${ }^{520}$

Az utolsó lépések, amelyek a beavatkozás irányába mutattak nemzetközi szinten, november elején és közepén az ENSZ 1996. november 9-i 1078. számú határozata, valamint 1996. november 15-i 1080. számú határozata. Ezekben a dokumentumokban az Egyesült Nemzetek Szervezete megerősítette, hogy a menekülteknek vissza kell térniük Ruandába, a konfliktusról regionális szinten egyeztető konferenciát kell tartani, és egy nemzetközi humanitárius haderöt kell a helyszínre küldeni a helyzet rendezése érdekében. ${ }^{521}$

A határozatok a fentebb említett két álláspont (a menekültkérdést és a humanitárius válságot külön és egyben kezelők) közötti konszenzust tükrözik. Alapvetően humanitárius misszióról szól a határozatok szövege, nyitva hagyják azonban az ajtót a katonai misszió felé. Humanitárius folyosók kialakítását is megemlítik, amelyeken keresztül a menekültek hazatérhetnének Ruandába. Ez az elképzelés megfelelt a francia és amerikai álláspontnak is (a franciák humanitárius beavatkozást akartak, az amerikaiak a menekültek hazatérését szorgalmazták). ${ }^{522}$

A november 9-i határozat tíz napot adott a fötitkárnak arra, hogy jelentést állítson össze a Zairéba küldendő nemzetközi haderő felállításának részleteiről. Időközben Kanada jelezte, hogy hajlandó megszervezni egy 6-10.000 fös alakulatot ${ }^{523}$, az

\footnotetext{
${ }^{518}$ US weighs troop use in Zaire crisis, International Herald Tribune, 1996. november 6.

${ }^{519}$ Dupont, Patrick: La communauté internationale face à la question de l'intervention humanitaire lors de la rébellion au Kivu (octobre-decembre 1996), http://www.ua.ac.be/objs/00110972.pdf, [2013.02.06.]

${ }^{520}$ UN Department of Humanitarian Affairs, Integrated Regional Information Network: Weekly Roundup of Main Events in the Great Lakes Region , No. 34., 1996. november 3-10.

521 S/RES/1078 (1996), 1996. november 9. S/RES/1080 (1996), 1996.november 15.

${ }^{522}$ Dupont, Patrick [1996]

${ }^{523}$ Canada Agrees to Lead Military Force in Zaire, International Herald Tribune, 1996. november 12.
} 
Amerikai Egyesült Államok pedig kijelentette, hogy 3-5000 katonával hozzájárulna a zairei misszióhoz. $^{524}$

A november 15-i határozat megköszönte az addigi felajánlásokat, valamint felkérte az ENSZ valamennyi tagállamát, hogy ha teheti, járuljon hozzá a zairei kontingens felállításához. A határozat azt is leszögezte, hogy a misszió 1997. március 31-ig tartózkodik majd az országban, hacsak nem sikerült hamarabb befejezni a menekültek hazajuttatását, a humanitárius segítségnyújtást. A határozat jelzi, hogy az ENSZ a hosszabb távú jelenlétet is kérheti, ennek felülvizsgálatára 1997. január elsejéig kerül sor.

A zairei misszió mellé felsorakozó országok azonban gyorsan kihátráltak a terv mögül, amikor 1996. november 15-én a gomai Mugunga menekülttábor megtámadása után a menekültek hatalmas tömegben elkezdtek visszatérni Ruandába. ${ }^{525}$ November 15-től 17-ig mintegy 400.000 menekült lépte át a határt, a Zairéban tartózkodó ruandai menekültek mintegy harmada. ${ }^{526}$

A hatalmas visszatérési hullám hatására a beavatkozást fontolgató nemzetközi közvélemény nagy része (kivéve Franciaországot) megoldottnak tekintette a problémát. $^{527}$

Nem számoltak azonban a konfliktus elhúzódó jellegével, hiszen az egyesült AFDL, ruandai és burundi seregek tovább üldözték azokat a menekülteket, akik nem tértek vissza származási országukba. A Zaire területén keletről nyugat felé tartó embertelen hajsza eredményeképpen mintegy 200.000 menekült „eltűnt”. Habár a Zairéban maradtak és a Ruandába visszatértek számát többször is módosították a hatóságok, mintegy 200.000 före tehető azok száma, akiket -a fentiek alapján nyugodtan állíthatjuk- egy megszervezett, átgondolt katonai akció keretében, a nemzetközi közösség tudomásával eltávolítottak az élők sorából.

Az atrocitások súlyosságáról szóló ENSZ-jelentésre 14(!) évet kellett várni. 2010ben jelent meg a Kongói Demokratikus Köztársaság területén 1993 és 2003 között elkövetett tömeges emberi jogi jogsértésekről szóló összefoglaló, amely kiemelten

\footnotetext{
${ }^{524}$ Zaire: Clinton Agrees to Contribute Troops to Mission, International Herald Tribune, 1996. november 14.

525 United Nations, Integrated Regional Information Network (IRIN), Bulletin, No.s 25 - 27,1996. november 15-18.

${ }^{526}$ Les Hutu réfugiés dans les camps du Zaïre regagnent massivement le Rwanda, Le Monde, 1996. november 18.

${ }^{527}$ Karacs,Imre [1996]: Zaire Military Option Ruled Out, The Independent, 1996. november 25.
} 
tárgyalja az 1996-ban a ruandai kormányerők által a menekültek sérelmére elkövetett cselekményeket.

\subsection{Nemzetközi reakció a 2010-es ENSZ-jelentésre}

2010. október elsején hozták nyilvánosságra az ENSZ Emberi Jogi Főbiztossága által kiadott 566 oldalas jelentést Kongóról ’DRC: Mapping Human Rights Violations 19932003" (Kongói Demokratikus Köztársaság: Emberi Jogi Jogsértések Feltérképezése 1993-2003-ig) címmel. A jelentést vázlatos formában már megjelenése előtt kiszivárogtatta a Le Monde c. francia napilap, óriási felháborodást okozva.

A dokumentumban szereplő vádak és a terminológia ellen számos kormány tiltakozott már az előzetes vázlatot áttekintve. A jelentés 617 atrocitást részletez, főleg Kelet-Kongóban 1993 márciusa és 2003 júniusa között. Ami a szóhasználatot illeti, a ruandai kormány föleg azt kifogásolta, hogy a független bizottság szerint a „nyilvánvalóan szisztematikus és széleskörü támadások, amelyek a jelentésben szerepelnek olyan terhelő elemeket mutatnak, amelyek ha bizonyítást nyernek a

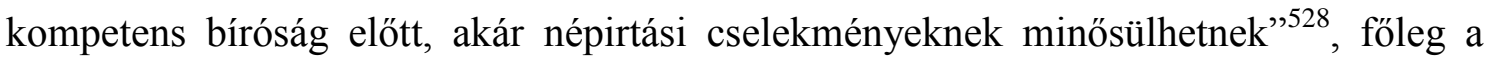
ruandai csapatok által 1996-97-ben elkövetett atrocitásokra utalva. ${ }^{529}$ Navi Pillay, az ENSZ emberi jogi főbiztosa a jelentés előszavában kiemelte, hogy nem a harc hevében véletlenszerüen megölt emberekről, hanem az AFDL (Alliance of Democratic Forces for the Liberation of Congo), az RPA (a ruandai hadsereg), valamint az FAB (a burundi hadsereg) által célzottan kivégzett áldozatok százairól van szó.

Ruanda kormánya „határozottan elutasította"530 a jelentést, és azzal fenyegette meg a nemzetközi közösséget, hogy visszavonja 3300 békefenntartóját a szudáni Dárfúrból, ${ }^{531}$ ahol pedig a ruandai katonák kulcsszerepet játszanak az Afrikai Unió és az ENSZ közös békefenntartó missziójában.

A jelentés megalapozott, hiszen 1280 áldozattal készült interjúra alapozza állításait, valamint 1500 írásos dokumentum elemzésére hivatkozva közli, hogy bizonyos paraméterek alapján célzottan kongói, valamint hutu fegyvertelen menekülteket (föleg

\footnotetext{
528 31. oldal

529 UN releases Congo genocide report. http://www.hrw.org/news/2010/10/01/dr-congo-un-reportexposes-grave-crimes [2013.01.31.]

${ }^{530}$ Ibid.

${ }^{531}$ A 21800 fös nemzetközi kontingens vezetője is egy ruandai ezredes.
} 
nőket, gyerekeket és idősebbeket) ${ }^{532}$ öltek meg a felfegyverzett katonai egységek. A szövegezésben a ruandai kormány egységeit népirtási cselekményekkel vádolja meg.

Ruanda hivatalos kommentárt füzött a jelentéshez, amelyben hangsúlyozta, hogy a jelentést összeállító szakértők nem vették figyelembe a történelmi kontextust és Ruanda fenyegetettségét. A kommentárban kiemelik, hogy a civileket a felfegyverzettektől nagyon nehéz volt megkülönböztetni, ennek az eredménye a járulékos áldozatok nagy száma. („Csakúgy, mint más hasonló helyzetekben, amikor terrorista csoportok és lázadók civilek és menekültek közé vegyülnek és nem hordanak egyenruhát, vagy más módon nem követik a fegyveres konfliktusok jogát, az illegális kombattánsok és civilek elkülönítése nem mindig lehetséges. Ez az elkülönítési nehézség az 1994-ben végrehajtott népirtás következménye, amikor az átlagemberek tömegesen részt vettek az atrocitásokban. Az elkülönítési nehézség másik oka a zairei táborokban élő menekültek - néha erőszakos- katonai mobilizációja"). ${ }^{533}$

\footnotetext{
${ }_{532} \mathrm{http} / / / \mathrm{www}$. responsibilitytoprotect.org/index.php/crises/crisis-in-drc, [2013.01.31.]

${ }^{533}$ Republic of Rwanda: Ministry of Foreign Affairs and Cooperation[2010]: Official Governemnt of Rwanda Comments ont he Draft UN Mapping Report on the DRC, 11.old.
} 


\section{8. fejezet: Következtetések, összegzés}

\subsection{Első tézis}

Az előző fejezetben ismertetett esettanulmányok több szempontból is alátámasztják a disszertáció első részében felvázolt hipotéziseket.

A genocídium fogalma napjainkban továbbra sem egyértelmü, mivel az elsődleges jogforrás, A Népirtás Megelőzéséről és Megbüntetéséről Szóló Egyezmény szövege is számos kérdést vet fel. A fogalom világos, objektív körülhatárolása mind a tudományos, mind a hétköznapi életben feltétlenül szükséges a hatékony megelőzéshez. A hatékony megelőzéshez álláspontom szerint a védett csoportok körét bővíteni kellene.

Elöször tekintsük át, hogy miért is lenne fontos az esettanulmányok fényében módosítani az ENSZ Genocídium-egyezményét. Amint azt a disszertáció vonatkozó fejezetében kifejtettem, a genocídium jogi fogalma a védett csoportok tekintetében túlságosan szük körü.

Ha végiggondoljuk a burundi, ruandai és zairei/kongói esettanulmányokat, arra az elhamarkodott következtetésre juthatunk, hogy a három ismertetett konfliktus etnikai alapú volt. Azonban a népirtás mindhárom esetben szorosan kapcsolódott a politikai konfliktusokhoz.

\subsubsection{Burundi}

Burundiban a függetlenség elnyerése után kezdtek teret nyerni az etnikai alapú feszültségek a politikai életben. A hatvanas éveket megelőzően a konfliktusok vegyes etnikai összetételű érdekcsoportokat állítottak szembe egymással, míg a ruandai forradalom után (amikor 1961-ben a szomszédos, hasonló etnikai összetételü országban a többségben lévő hutuk jutottak hatalomra és kikiáltották a ruandai hutu köztársaságot) a hutu származású burundi lakosság reménykedni kezdett egy ruandai rendszerhez hasonló jövőben. A Burundiban élö tutszik viszont úgy érezték, veszélyben forog kisebbségi dominanciájuk (a hadsereg, rendőrség és politikai elit hagyományosan nagyrészt tutszi származású volt), főleg az 1965-ös választásokon aratott földindulásszerü hutu győzelem után. A tutszik a hatalmat a választások után erőszakkal 
megtartották, és 1972 elött többször is erőszakkal elnyomták a hutu hatalomátvételi (a hutukat kizárták többek között a kormányból és a civil szférából) kísérleteket.

A különféle tutszi törzsek közötti viszony elmérgesedése miatt 1972-ben hutu értelmiségi csoportok úgy vélték, hogy ideális az időpont a hutuk elnyomott helyzetének megváltoztatására, és felkelést robbantottak ki. Ennek a felkelésnek az aránytalanul durva leverése torkollott népirtásba. A zavargásokat nem egyszerüen vérbe fojtották, hanem a kormány (ráadásul zairei segítséggel) hónapokon keresztül folytatta tovább a hutu értelmiségiek megsemmisítését. A nyilvánvaló cél a tutszi hatalom megszilárdítása volt, hosszú távon pedig az, hogy leszámoljanak a jövő potenciális felkelőivel is. Mivel az 1972-es népirtás előtti években a tutszi elit folyamatosan kisebbnagyobb hutu zavargásokkal küzdött, úgy döntött, egyszer és mindenkorra „lefejezi” a többségi hutukat. Ahogy Michael Hoyt amerikai nagykövet fogalmazott egyik sürgönyében: „Ez egy kísérlet, hogy megtagadják tőlük [a hutuktól- a Szerző] a munka, tulajdonlás, oktatás és úgy általában a fejlődés lehetőségét."

A kormány célja az erőviszonyok megváltoztatása, a kisebbség uralmának, a többség elnyomásának bebetonozása, a tutszi hegemónia biztosítása volt. Ennek megfelelően nem válogatás nélkül végeztek a hutu lakosokkal, hanem célzottan az elitet, a hutu értelmiséget üldözték. Azok az értelmiségiek, akik nem estek áldozatul a hónapokig tartó erőszakhullámnak, külföldre menekültek, így önkéntelenül is segítették a tutszi vezetés jövőképének megvalósulását.

Ebben az esetben tehát az elkövetö által meghatározott kritérium volt egyrészt az etnikai hovatartozás, másrészt a hutu csoporton belül betöltött jelenlegi vagy jövőben megvalósuló vélt vagy valós értelmiségi vagy vezető szerep. Az idő előrehaladtával szigorúbb szabályokat alkalmaztak mind az etnikum (például már a nagyszülők közötti egyetlen hutu felmenő is elegendő volt a hutunak minősítéshez), mind az „értelmiség” meghatározására. Míg a felkelés leverése közben és után nem sokkal a felbujtókkal, egyetemistákkal és politikai aktivistákkal végeztek, valamint a közhivatalokban és hadseregben dolgozókkal, nemsokára sorra kerültek a középiskolások, végül már az általános iskolások is (akikben az elkövetők a jövő értelmiségét látták megtestesülni).

\footnotetext{
${ }^{534}$ Hoyt, Michael. [1972]: US Embassy Cables from Bujumbura to State Department. Unpublished materials available from the University of Florida Libraries, Gainesville
} 


\subsubsection{Ruanda}

Ami a ruandai esetet illeti, ott a mérsékelt hutuk megölése „nem illik” a Genocídiumegyezmény szük jogi keretei közé.

Ruandában a belga gyarmatosítók pozitívan diszkriminálták a tutszi kisebbséget, akit rátermettebbnek és a fehér emberhez hasonlóbbnak (tehát vezetésre alkalmasabbnak) találtak. A gyarmatosítás végének közeledtekor a tutszik privilegizált helyzete kezdett megváltozni, ${ }^{535}$ a hutuk elkezdhettek dolgozni az állami közigazgatásban és gyermekeik az általános iskola után (a korábbiaktól eltérően) továbbtanulhattak.

1959-61-ben viszonylag békés hatalomátvétel (hutu forradalom) zajlott le, amelynek során a hutuk fokozatosan átvették a hatalmat, majd 1962-ben, Ruanda függetlenné válásakor a hutuk alakítottak kormányt. Az általános tutsziellenes közhangulat következtében sok tutszi elmenekült Ruandából, és az országot körülvevő menekülttáborokból folyamatosan ellenséges betöréseket hajtottak végre. ${ }^{536} \mathrm{~A}$ kormányerők ezt a kollektív bünösség elve alapján gyakran a Ruandában maradt tutszik elleni pogromok során bosszulták meg. Tovább rontotta a helyzetet az 1972-es Burundiban zajló hutuk elleni népirtás, amelynek elkövetői tutszik voltak. Ruandában országszerte tutsziellenes zavargások törtek ki. Juvénal Habyarimana tábornok 1973ban az anarchiaközeli állapotokat kihasználva sikeres puccsot hajtott végre, és elkezdődött a második köztársaság eleinte gazdasági sikereket hozó korszaka. Habyarimana kerülte az etnikai hovatartozás kérdését, a nemzeti egységre igyekezett helyezni a hangsúlyt.

A Habyarimana-rezsim eleinte mind politikailag, mind gazdaságilag stabilnak tünt. A nyolcvanas évek végére azonban több tényező is hozzájárult a rendszer aláásásához: egyrészt az ugandai menekülttáborokban megalakult az RPF, amelynek célja a ruandai menekültek hazatérésének elősegítése. Amikor a kormány 1986-ban bejelentette, hogy több menekült nem térhet haza a magas ruandai népsürüség és földhiány miatt, az RPF a fegyveres megoldás felé mozdult el. A Habyarimana-rezsim koporsójába újabb szöget ütött a kávé (Ruanda fö exportcikke) árának világpiaci zuhanása.

1990-ben az RPF offenzívát indított a kormány ellen, amely nem hozott gyors sikereket: a kormányerők és az RPF közötti harcok állandósultak. A tutszi menekültek

\footnotetext{
${ }^{535}$ Többek között mivel a belga gyarmatosítók elfordultak a függetlenséget követelő tutszi elittől és az „engedelmesebb” hutukat kezdték támogatni.

${ }_{536}$ UNHCR [2010], 95.old.
} 
ügyéért harcoló RPF-et a tutsziellenes propaganda azonosította az egész tutszi etnikummal. A rasszista propaganda arról győzködte a ruandai hutu lakosságot, hogy a tutszik célja az egész afrikai Nagy Tavak régió feletti uralom megszerzése és a hutuk kiirtása. Hiába igyekeztek a politikailag mérsékelt hutuk tárgyalni a kormányellenes felkelőkkel, a radikálisok árulónak bélyegezték őket. Amikor 1994. április 6-án Habyarimana elnököt megölték, elszabadultak az indulatok és tutsziellenes népirtás kezdődött.

A népirtás áldozatául estek azonban a tutszikon kívül a mérsékelt hutuk is. A népirtás mintegy 500.000 tutszi és 10.000 és 30.000 közötti hutu áldozatot szedett. Az ellenzéki politikusok és a liberálisok kiemelt célpontjai voltak a genocídiumnak. Bárki, aki tárgyalt volna az RPF-erőkkel vagy védelmébe vette a tutszikat, aggódhatott az életéért.

Tehát az elkövető által meghatározott kritériumok Ruanda esetében: vagy tutszi (etnikai hovatartozás), vagy mérsékelt álláspontot képviselő hutu ruandaiak estek áldozatul a genocídiumnak. Ez utóbbi esetben a politikai véleménykülönbség képezte a megsemmisítés alapját. A faji, nemzeti, etnikai vagy vallási csoportok ellen elkövetett népirtások általában szorosan kapcsolódnak a politikai konfliktusokhoz. A második fejezetben tárgyalt alternatív népirtás-definíciók kapcsán felmerült BARBARA HARFF, aki megalkotta a ,politicídium” kifejezést. HARFF hangsúlyozta, hogy a népirtó rendszerek szemében gyakran a politikai hovatartozás az „ártatlanság” vagy „,bünösség” mércéje. $^{537}$

Így történt ez Ruandában is, ahol a genocídium jogi fogalma alapján nem minősülne népirtásnak a mintegy tíz- és harmincezer közötti mérsékelt hutu megsemmisítése, azonban az általam javasolt, kibővített definíció alapján igen.

\subsubsection{Zaire}

A zairei esetben a Genocídium-egyezmény jelenlegi szövege is tökéletesen megfelelt volna arra, hogy nevén nevezzék, ami történt. Erre azonban első alkalommal csak 2010ben történt utalás az ENSZ Emberi Jogi Főbiztosságának ’DRC: Mapping Human Rights Violations 1993-2003” (Kongói Demokratikus Köztársaság: Emberi Jogi Jogsértések Feltérképezése 1993-2003-ig) címmel kiadott jelentésében. Korábban csak

\footnotetext{
${ }^{537}$ Harff, Barbara [2009]: Recognizing Genocides and Politicides, In: Genocide Studies Reader, Bartrop, Paul R.; Totten (ed.):, Samuel, Routledge
} 
„elszigetelt” tudományos körökben ${ }^{538}$ fordult elő, hogy az 1996-ban kezdődött kivui válságot népirtásnak nevezték.

Pedig a népirtás minden „összetevője”, eleme adott volt. Mikor kezdett nyilvánvalóvá válni, hogy az 1994-es ruandai népirtás az RPF győzelmével fog zárulni, Franciaország vezetésével nemzetközi haderő érkezett Ruandába és biztonsági zónát (Opération Turquoise) hozott létre Ruanda délnyugati részén. Ezen a biztonsági zónán keresztül számos elkövető (génocidaire) menekült át Zairéba. Ugyanakkor fegyvertelen civil hutuk százezrei is elhagyták az országot. Túlzás lenne tehát azt állítani, hogy a Zairéban tartózkodó ruandai menekültek nagyrészt elkövetők voltak. Az ENSZ Menekültügyi Főbiztosságának becslései szerint az összes zairei menekültnek kb. hét százaléka volt elkövető. ${ }^{539}$ Ezek a fegyveresek nem tettek le eredeti szándékukról, vissza akarták hódítani Ruandát, esetleg uralmuk alá hajtani Kelet-Zairét. Elkezdték a régóta Zairéban élő ruandai, tutszi eredetü banyamulenge etnikum és a kivui lakosság zaklatását, mészárlását. ${ }^{540}$

Zaire keleti része (Észak- és Dél-Kivu), amely határos volt Ruandával, és ahova a menekültek átléptek, már évtizedek óta viszályoktól terhes régiónak számított. Az államhatalom a Mobutu-éra vége felé, a kilencvenes évek elejére igencsak meggyengült, Kelet-Zaire (mind földrajzilag, mind fizikailag) elszigetelődött a fővárostól, és ,,egyedül maradt" konfliktusaival. ${ }^{541}$

1937 után a belga gyarmatosítók Észak-Kivuba telepítettek mintegy 85.000 főnyi banyarwandát (hutuk-tutszik vegyesen). A banyarwandák igyekeztek (akár a helyiek kárára is) földhöz jutni. A földért vívott harc rányomta a bélyegét a helyiek és a banyarwandák viszonyára, amelyet tovább súlyosbított az állampolgárság kérdése. 1972-ben olyan törvény született, amely minden, Ruandából érkező, de legalább 1960 óta Zairéban élő banyarwandának megadta a zairei állampolgárságot, 1981-ben azonban ezt érvénytelenítették és de jure megfosztották a banyarwandákat állampolgárságuktól.

\footnotetext{
${ }^{538}$ Lemarchand, René [1998]: Genocide in the Great Lakes: Which Genocide? Whose Genocide? African Studies Review, Vol. 41, No. 1, 3-16.oldal, Adelman, Howard, Govind, Rao [2004]: War and Peace in Zaire-Congo: Analyzing and Evaluating Intervention, 1996-1997, 116.oldal: Masisi-Genocide continued ${ }_{539}$ Prunier, Gerard [2009]: From genocide to continental war: the Congolese conflict and the crisis of contemporary Africa, 125.old. idézi „Massacres au Zaire:Le témoignage qui réveille les Occidentaux, Libération, 1997.03.10.

${ }^{540}$ Millwood, David [1996]: The International Response to Conflict and Genocide: Lessons from the Rwanda Experience, Studies 1-4 (Joint Evaluation of Emergency Assistance to Rwanda, March 1996), Study 2, 94 (note 129)

541 Prunier, Gérard [1998. július]: Power struggle in Kivu- Congolese flashpoint. http://mondediplo.com/1998/07/08kivu [2013.01.14.] és Emizet, Kisangani N.F. [2000]: The massacre of refugees in Congo: a case of UN peacekeeping failure and international law, The Journal of Modern African Studies,38,2
} 
Az öslakosoknak a banyarwandák földjére és tulajdonára fájt a foga, így az északkivui lakosság mintegy 40 százalékát kitevő banyarwandák és az őslakosok között a kilencvenes évekre mindennapossá váltak az összecsapások.

Dél-Kivuban ugyanakkor csak a lakosság 3-4\%-a volt banyamulenge (nagyrészt tutszi ruandai betelepülő). Az első zairei polgárháború során belekeveredtek a törzsek közötti harcokba és emiatt a dél-kivui babembe törzzsel hosszú távra feszültté vált a viszonyuk. Amikor Ruandában kitört a háború, az RPF sikerrel toborzott a banyamulengék köréböl, akik harci tapasztalatot akartak szerezni a népcsoport ingatag dél-kivui helyzetére való tekintettel.

Ebbe az eleve feszült észak- és dél-kivui helyzetbe „robbant be” a mintegy 1.200.000 ruandai menekült és a velük együtt beszivárgó elkövetők, és mindkét régióban megbontották az öslakosok és Ruandából bevándoroltak közötti törékeny egyensúlyt.

A menekültek közé vegyült fegyveresek betöréseket hajtottak végre Ruanda területére zairei bázisaikról. A helyi lakosság bizonyos elemei (általában a hutuk és az őslakosok) is támogatták őket, míg más helyi csoportok ellenük fordultak (általában a tutszi származásúak). A gyenge államhatalmat kihasználva a felfegyverzett génocidaireek saját „felségterületüknek”, katonai bázisuknak tekintették Kelet-Zairét.

Paul Kagame, akinek vezetésével az RPF megbuktatta a népirtó rezsimet, 1996 őszén úgy döntött, megtámadja a táborokat. Zairéba a hutu milíciák üldözésének ürügyével október elején mélyen és tartósan behatoló RPF-erők ${ }^{542}$ összefogtak a banyamulengékkel, valamint az RPF segítségével formálódó Mobutu-ellenes gerillacsoporttal, az AFDL-lel. A zairei beavatkozást Ruanda 1996-ban mindvégig tagadta, 1997-ben azonban Kagame elismerte, hogy a ruandai kormányerök ott voltak Zairéban 1996-ban. ${ }^{543}$ Saját bevallása szerint elsődleges céljuk a „táborok leépítése” volt, másodsorban a táborokban és körülöttük élő hutu elkövetői ,hálózat (a génocidaire-k) lerombolása”, harmadrészt pedig a zairei diktátor, Mobutu megbuktatása.

Kagame úgy fogalmazott, hogy „szerencsésebb lett volna, ha a kongói lázadók nagyrészt maguk harcolnak Mobutu csapataival, de kockázatosabb is lett volna. [...]

\footnotetext{
542 Szabó Loránd: Kongó - válsággóc Kelet és Nyugat között •Vázlat a Zaire/Kongói Demokratikus Köztársaság 1995-2005 címü előadás írott változatához. http://www.afrikatanulmanyok.hu /application/essay/790_1.pdf [2013.01.14.]

${ }^{543}$ Pomfret, John: Rwandans Led Revolt In Congo

http://www.washingtonpost.com/wp-srv/inatl/longterm/congo/stories/070997.htm, [2013.02.10.]
} 
Véleményem szerint nem voltak rá teljesen felkészülve. A továbbiakban is vállaltunk szerepet, mert úgy gondoltuk, hogy a felemás eredmény nagyon veszélyes lenne. Úgy véltük, a legjobb az lesz, ha végigvisszük [Mobutu megbuktatását- a Szerző]."

Ez sem magyarázat azonban arra, hogy a táborok megtámadása után a ruandai hadsereg vezette erők miért üldözték és ölték meg a Zaire nyugati része felé menekülőket. Módszeresen követték a a menekülteket, lerombolták sebtében kialakított táboraikat. Ellenőrző pontoknál „szürték ki” akcentus, ruházat vagy arc- és testfelépítés alapján ruandai vagy burundi hutunak ítélt embereket és kivégezték őket. Más esetekben a menekültek közül kiválogatták a fiatal férfiakat, és lelőtték őket.

Egy segélyszervezet munkatársa így emlékszik vissza az eseményekre: „Amikor a lázadók átvették az adott területet [...] megakadályozták, hogy az UNHCR munkatársai felvegyék a kapcsolatot a menekültekkel, megtámadták a táborokat, és megöltek minden férfit, akiről azt gyanították, hogy a fegyveres ellenséghez tartozik. Ennek során, szándékosan vagy sem, nagyon sok más menekültet is megöltek. A segélyszervezetek nem közelíthették meg a tömegsírokat." 545

Az Egyezmény szerint népirtást követ el, aki valamely nemzeti, etnikai, faji vagy vallási csoport teljes vagy részleges kiirtása céljából a csoport tagjait megöli, vagy a csoport tagjainak súlyos testi vagy lelki sérelmet okoz, vagy a csoportot olyan életfeltételek közé kényszeríti, amelyek azt vagy annak egyes tagjait pusztulással fenyegetik, vagy olyan intézkedést tesz, amelynek célja a csoporton belül a születések meggátolása, vagy a csoporthoz tartozó gyermekeket más csoportba elhurcolja.

Amikor a helyi Banyamulenge, a ruandai és AFDL-erők frontális támadást hajtottak végre a hutu menekülttáborok ellen, a célcsoport számos tagját megölték. Azzal, hogy az elmenekülök közül a Zaire belseje felé tartókat tovább üldözték, olyan életfeltételek közé kényszeritették a csoportot (erőltetett menetelés, gyakran élelem és víz nélkül), amelyek a csoport tagjait pusztulással fenyegették. Ráadásul számtalan alkalommal előfordult, hogy az út mentén bujkáló menekültek a segélyszervezetek munkatársai láttán előjöttek, és a katonák akkor csaptak le rájuk.

A ruandai hadsereg részéröl sok esetben semmilyen eröfeszités nem történt, hogy elválasszák a népirtás felelöseit, a felfegyverzett menekülteket a fegyvertelen

544 Pomfret, John [1997]: Rwandans Led Revolt in Congo, Washington Post Foreign Service Wednesday, July 9 1997; Page A01 http://www.washingtonpost.com/wpsrv/inatl/longterm/congo/stories/070997.htm

${ }^{545}$ UNHCR Publications [2000]: The State of The World's Refugees 2000: Fifty Years of Humanitarian Action. Chapter 10: The Rwandan genocide and its aftermath. http://www.unhcr.org/3ebf9bb60.html, 271.old. 
tömegektől. Az Afrikai Egységszervezet szakértői a ruandai népirtás és következményeiről írt jelentésében a Zairéban zajló atrocitásokat „hutu civilek válogatás nélküli meggyilkolásának" nevezi. ${ }^{546}$

A „felkelők” [...] azt állítják, hogy minden menekült, aki nem tért vissza Ruandába, elkövető [...]. Azonban a menekülteket elkövetőknek nevezni [...] hasonló ahhoz, amikor az Interahamwe-tagok [1994-ban Ruandában - a Szerző] csótánynak (inyenzi) titulálták áldozataikat, hogy könnyebb szívvel tudjanak ölni. [...] Akiket megölnek, nem gyilkosok, hanem családok, akik nem tudnak gyorsabban futni, mint a velük menekülő gyerekek. Ök menekülnek és halnak meg csoportosan [...]. Az Interahamwe és volt-FAR [ruandai kormányerök az 1994-es népirtás idején - a Szerző], akik a legtöbb gyilkosságot elkövették, fiatalok és erősek. Gyorsan futnak és van fegyverük [...]" - írta Balas atya, egy Kelet-Zairéban tevékenykedő misszionárius. ${ }^{547}$

A menekültek vesszőfutása és az ellenük irányuló rajtaütések mintegy 200.000 áldozatot szedtek. ${ }^{548}$

Összesítve tehát a három esettanulmány közül kettő nem felel meg teljes egészében a Genocídium-egyezmény jogi definíciójának. Bár a harmadik, zairei incidens álláspontom szerint meghatározható genocídiumként (ha a Genocídium-egyezmény definícióját vesszük alapul), a tizennégy évvel később készült ENSZ-jelentés még mindig csak „népirtási cselekményekként” (genocidal acts) aposztrofálja a ruandai hadsereg által elkövetett túlkapásokat.

A genocídium a legsúlyosabb büntett, éppen ezért a szó használatától ódzkodnak mind a politikusok, mind a jogászok. A disszertációban tárgyalt esettanulmányok mindegyikére jellemző, hogy az atrocitásokat, amíg folyamatban voltak, a döntéshozók nem nevezték genocídiumnak. Ez a „g betüs szó"549 (ahogy politikai körökben meghonosodott az elnevezése) félelemmel tölti el használóját, mert egyben felszólítás is a cselekvésre.

\footnotetext{
546 OAU: Rwanda - The preventable genocide. http://www.africa-union.org/official ${ }_{547}$ documents/reports/report_rowanda_genocide.pdf 20.79

${ }_{547}$ Prunier, Gerard [2009]: From genocide to continental war: the Congolese conflict and the crisis of contemporary Africa, 126.old. idézi Massacres au Zaire: Le témoignage qui réveille les Occidentaux, Libération, 1997.03.10.

548 Prunier, Gérard [1998. július]: Power struggle in Kivu- Congolese flashpoint. http://mondediplo.com/1998/07/08kivu [2013.01.14.]

${ }_{549}$ The uses and abuses of the G-word, The Economist, 2012. június 2.

http://www.economist.com/node/18772664
} 
Ha azonban a fogalom világosabban körülhatárolt lenne, a védett csoportok körét bővítenék, és a népirtás-megelőzésre kialakulna egy széles körben bevett protokoll, talán a döntéshozók sem ódzkodnának a genocídium néven nevezésétől.

A következő részben a népirtások biztonsági kockázatát veszem górcső alá, majd ajánlásokat teszek egy hatékonyabb megelőzési rendszer kialakítására.

\subsection{Második tézis}

A nemzetközi közösségnek elemi érdeke lenne a genocídiumok megakadályozása, mert a népirtások nyomán kialakult menekültáradat súlyos instabilitást okozhat nemcsak belföldön és a szomszédos országokban, hanem a környező régióban is, a tovagyürűző (spillover) ${ }^{550}$ hatások miatt pedig negatívan befolyásolhatja a nemzetközi biztonságot.

“A menekültkérdés, valamint a béke és biztonság összefüggése talán sehol sem annyira nyilvánvaló, mint az afrikai Nagy Tavak régióban.” (Sadako Ogata, United Nations High Commissioner for Refugees 2000: 262)

A következő ábra a genocídium és a menekültkérdés kapcsolatán keresztül ábrázolja a konfliktusok alakulását.

8. ábra A genocídium és a menekültkérdés összefüggésében kialakuló konfliktusok

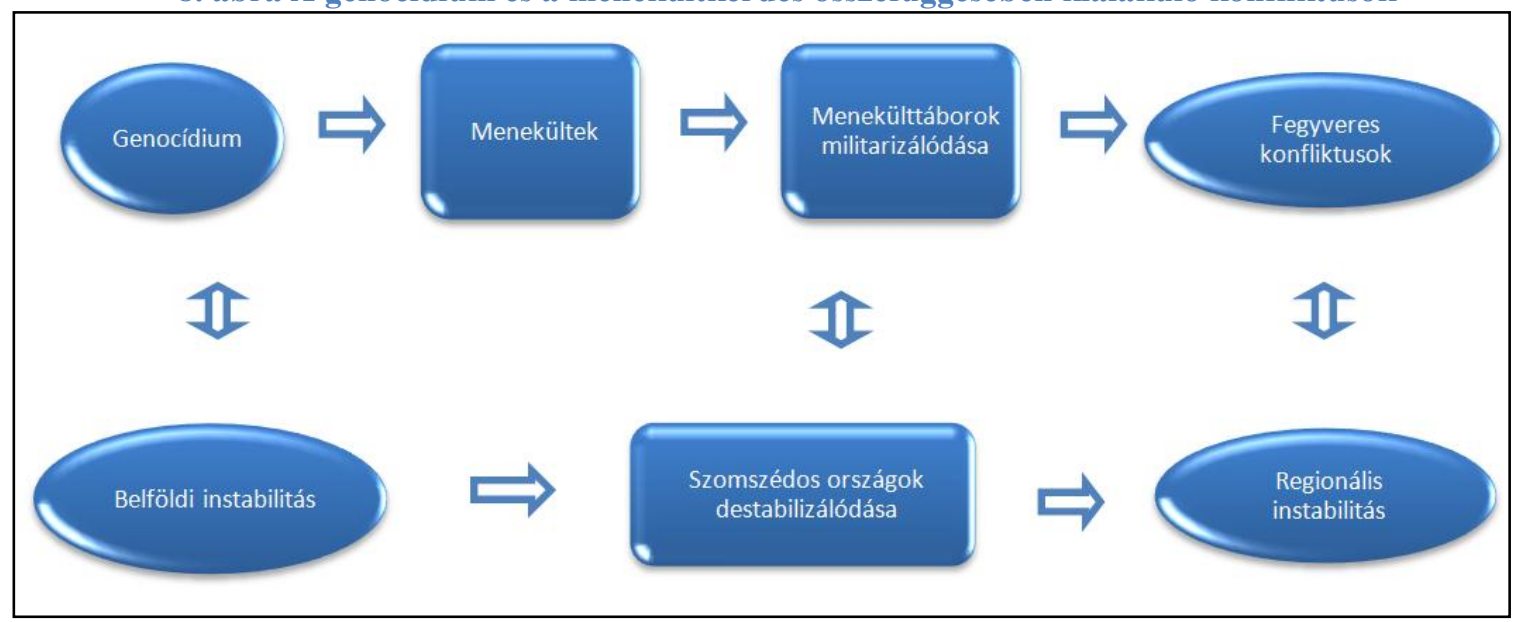

Forrás: saját szerkesztés

\footnotetext{
${ }^{550}$ Spill overről - tovaterjedésről, tovagyürüzésről - akkor beszélhetünk, amikor egy meghatározott célra irányuló cselekvés olyan helyzetet hoz létre, hogy az eredeti célt csak további lépésekkel lehet biztosítani, amelyek azután ismét további lépéseket szükségessé tevő újabb helyzethez, jelen esetben újabb konfliktushoz vezetnek, és így tovább.
} 
A Nagy Tavak Régió különböző országainak konfliktusai szorosan kapcsolódnak egymáshoz a menekültek áramlása révén.

\section{9. ábra Ruandai menekülltek Zaire felé tartanak}

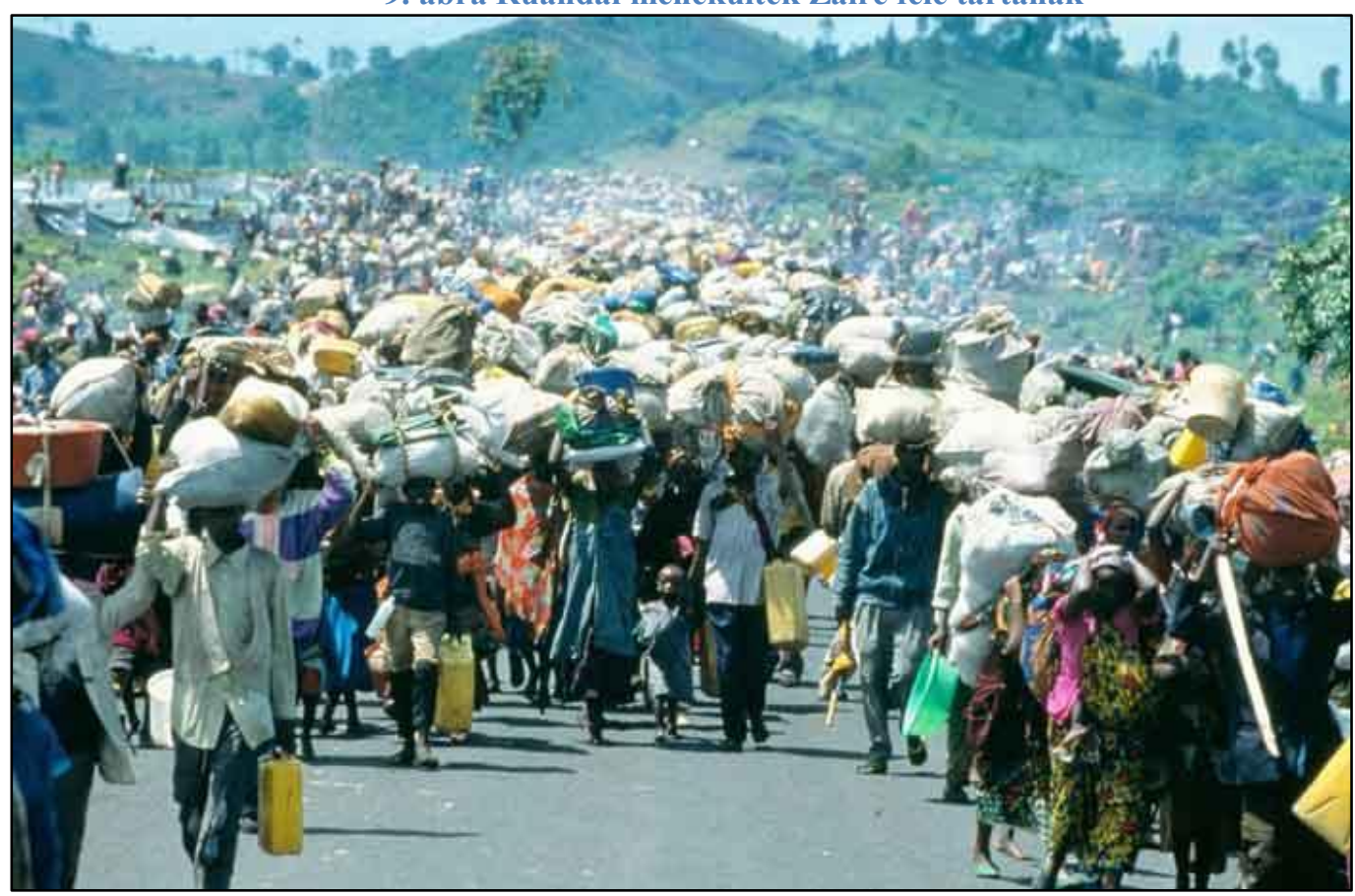

Forrás: Policy Penguin (2011): Evaluating the need for strategy: USAID in Rwanda post-genocide

A menekültáradat a fogadó országok számára gyakran negatív következményekkel jár. Maga a konfliktus, amely a menekülést előidézte, szintén átterjedhet a fogadó országra. A menekültek jelenléte növelheti a fegyveres konfliktusok kockázatát a befogadó és kibocsátó ország között. A fogadó országok célja általában a további negatív externáliák elkerülése, ${ }^{551}$ míg a kibocsátó országok a felfegyverzett menekültek üldözését folytatják- gyakran tekintet nélkül az országhatárokra.

A szakirodalomban megjelent már néhány tanulmány, ${ }^{552}$ amely arra utal, hogy a menekültek országok közötti konfliktusok okozói lehetnek. A disszertációmban bemutatott esettanulmányok alátámasztják ezt a hipotézist.

A következőkben a menekültek mozgását tekintjük át az elmúlt harminc évben, és mozgásirányuk hatását a regionális stabilitásra.

\footnotetext{
551 Salehyan, Idean [2007]: The Externalities of Civil Strife: Refugees as a Source of International Conflict. http://www.cas.unt.edu/ idean/RefugeesWar.pdf

552 Dowty, Alan and Gil Loescher [1996]: Refugee Flows as Grounds for International Action. International Security. 21(1):43-71. Posen, Barry [1996]: Military Responses to Refugee Disasters. International Security. 21(1):72-111. Weiner, Myron [1996]: Bad neighbors, bad neighborhoods: an inquiry into the conditions for refugee flows. Department of Political Science, MIT
} 


\subsubsection{A radikális hutu mozgalmak születése}

A Burundiban 1972-ben bekövetkezett hutuk elleni népirtás miatt Tanzániába, Ruandába, Zairéba elmenekülő mintegy 300.000 hutu csoportjaiból alakultak ki fokozatosan az első radikális fegyveres hutu mozgalmak. A Tanzániában található burundi menekülttáborok néhány éven belül hírhedtté váltak militarizáltságukról. Itt születtek meg a burundi tutszi uralom elleni első hutu felkelő mozgalmak, többek között a CNDD (Centre National pour la Défense de la Démocratie és szakadár csoportjuk, a CNDD-FDD), a PALIPEHUTU (Parti pour la Libération du Peuple Hutu), FROLINA (Front pour la Libération Nationale). Ezek a fegyveres csoportok a nyolcvanas évektől kezdve gerilla-akciókat hajtottak végre Burundi területére. Amikor 1993-ban a választásokon győzött a mérsékelt hutu Melchior Ndadaye és pártja, sok 1972-ben elmenekült hutu (mintegy negyvenezren) visszatért Burundiba. Annál nehezebb szívvel menekültek újra, amikor Melchior Ndadaye meggyilkolása után nem sokkal sorozatos, előbb a tutszi, majd a hutu népcsoportot sújtó atrocitások kezdődtek. Miután a tutszi Pierre Buyoya került hatalomra Burundiban, mintegy 700.000 hutu hagyta el az országot. Ezek egy része Ruandában telepedett le és tevékeny részt vállalt az 1994-es népirtásban. Másik része visszatért Tanzániába. Közülük sokan a PALIPEHUTU és FROLINA támogatóivá váltak. ${ }^{553}$

9. ábra A radikális hutuk eredete

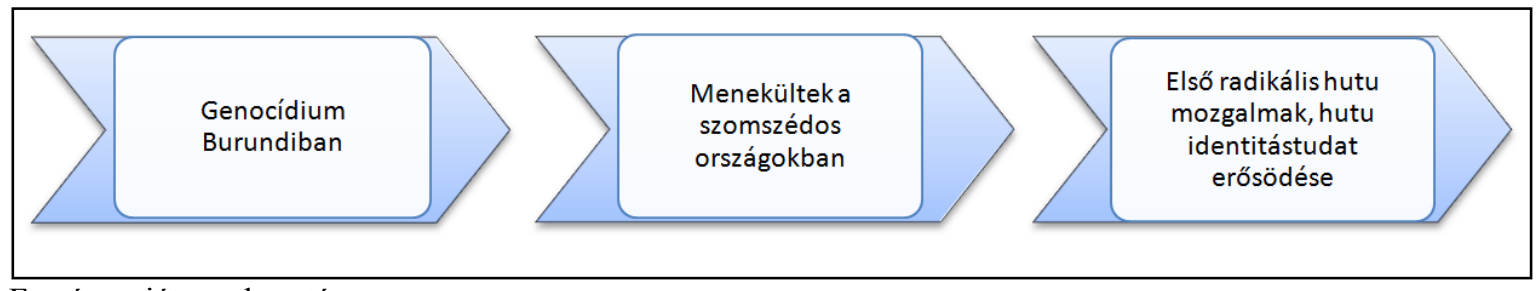

Forrás: saját szerkesztés

\subsubsection{A tutszi menekültek militarizálódása Ugandában}

A ruandai hutu forradalom közben (1959-61) és utáni években (hetvenes, nyolcvanas évek) tutszik százezrei hagyták el Ruandát a folyamatos tutsziellenes atrocitások miatt, és a környező országokban, nagyrészt Ugandában letelepedve próbáltak megélhetéshez jutni. Közben a visszatérést tervezgették, és amikor a Habyarimana-rezsim bejelentette, hogy a repatriálást a földhiányra való tekintettel felfüggeszti, feltörtek a legkeserübb hutuellenes érzések. A hutuk elüldözték őket a szülőföldjükről, és most még a

\footnotetext{
${ }^{553}$ Burundian Refugees in Tanzania: A Key Factor in the Burundi Peace Process. ICG Central Africa Report N 12, 25 November 1999, 2.old.
} 
visszatérésüket is megtiltották. Ezrek döntöttek úgy, hogy fegyveres úton kell kivívni a hazatérés lehetőségét. Ugandában megalakult az RPF, amelynek erői 1990-től kezdve gerillahadviselést folytattak a ruandai kormány ellen.

\subsubsection{A ruandai és burundi radikális hutu menekültek szövetségre lépnek Kivuban}

A ruandai mérsékelt hutu- és tutsziellenes népirtás után több százezer hutu menekült el Ruandából, nagy részük Zaire keleti részén, Észak- és Dél-Kivuban telepedett le. A népirtó rezsim vezetői a menekültekkel együtt átszivárogtak a határon, sok esetben az államkincstár és fegyvereik jó részét is vitték magukkal.

A korábbi ruandai kormány katonái (FAR), valamint az Interahamwe militánsai uralmuk alatt tartották a menekülttáborokat, felborították Kivu tartomány etnikai egyensúlyát, és fegyveres támadásokat intéztek a helyi tutszik ellen. 1995-re az erőszak általánossá vált, különösen Észak-Kivuban, amely inkább hasonlított egy alacsony intenzitású háborús övezetre, mint civil és humanitárius célokat szolgáló menekülttáborok gyüjtőhelyére.

Amint fentebb már említettem, számos burundi hutu Pierre Buyoya hatalomra kerülése után Ruandába menekült, és részt vett a népirtásban. Ök a népirtást elkövetőkkel és a menekültekkel együtt távoztak Ruandából. Voltak, akik hazatértek Burundiba, nagyobb részük a kelet-zairei menekülttáborokban találtak menedéket. Ezekben a táborokban katonai szövetségek köttettek. A Pierre Buyoya kormánya ellen harcoló, Kelet-Zairéban székelő burundi felkelők hírhedtté váltak a génocidaire-ekkel való együttműködésükről. A kezdeti időszakban a burundiak nagyban függtek ruandai szövetségeseiktől: tőlük kapták a fegyvereket, kiképzést, jármüveket. Később azonban kiépítették saját támogatói bázisukat. ${ }^{554}$

\subsubsection{A génocidaire-k további szövetségesei}

A korábbi FAR vezetői és az Interahamwe harcosok más szövetségeseket is gyüjtöttek: a zairei kormányerők katonáiból (akiket más jövedelem híján könnyű volt „megvásárolni”), valamint a helyi Mayi Mayi ellenzéki (Mobutu-ellenes) felkelőkből. Ezek az ad hoc szövetségek a helyi tutszi lakosokra támadtak. Ennek hatására 1995 novembere és 1996 februárja között kb. 37.000 tutszi menekült vissza Ruandába, közöttük számos olyan tutszi is, akik még az 1959-es forradalom kapcsán menekültek el

\footnotetext{
554 Burundian Refugees in Tanzania: A Key Factor in the Burundi Peace Process. ICG Central Africa Report $N^{\circ} 12,25$ November 1999, 3.old.
} 
Ruandából. Ezek a tutszi menekülttáborok csak néhány kilométerre voltak a ruandaizairei határtól, tahát a határ másik oldalán lévő szélsőséges hutu táboroktól is.

\subsubsection{Mobutu megbuktatása}

A militarizálódott menekülttáborok Zairéban, Ruanda határa mentén kiváltották a ruandai katonai beavatkozást 1996-ban.

Zaire keleti részén azonban már a ruandai menekülthullám érkezése és a ruandai beavatkozás előtt menedéket találtak a különböző szomszédos országok kormányai ellen küzdő fegyveres csoportok, többek között az ugandai Museveni elnök ellen harcoló ADF (Allied Democratic Forces) és LRA (Lord's Resistance Army), a José Eduardo dos Santos angolai elnök ellen lázadó UNITA (Uniao Nacional para a Independencia Total de Angola), vagy a burundi tutszi kormány ellen küzdő CNDD. ${ }^{555}$

Mobutu megdöntésében számos más afrikai ország hadserege is részt vett. Ugandai katonák a konfliktus ideje alatt Zairéban tartózkodtak, egyrészt azért, hogy a lázadó ugandai erők ellen küzdjenek, másrészt a ruandai vezetéssel ápolt szövetségesi kapcsolat okán is. Museveni elnök valószínüleg segített Kagaménak az AFDL irányításában is. A konfliktusban részt vett Angola is, amelynek kormánya a Mobuturezsim UNITA-nak nyújtott támogatásának akart véget vetni Mobutu megbuktatásával. Más külföldi aktorok kisebb mértékben vettek részt a Mobutu-rezsim elleni felkelés kapcsán kialakult harcokban. Burundi támogatta ugyan a ruandai és ugandai szerepvállalást, de nagyon kevés katonai segítséget küldött. Zambia és Zimbabwe is mérsékelt támogatást nyújtott a felkelőknek. Etiópia és Eritrea és a dél-szudáni SPLA felkelő hadsereg szintén anyagi és erkölcsi támogatói voltak a felkelők ügyének. Mobutut viszont támogatta a szudáni vezetés, akiket korábban Mobutu támogatott az SPLA(Sudan People's Liberation Army) elleni harcukban. ${ }^{556}$

\subsubsection{Kabila korábbi szövetségesei ellen fordul}

1997. május 17-én az AFDL bevonult a zairei fővárosba, Kinshasába, és Laurent-Désiré Kabila, az AFDL vezetője lett az államfö. Az ország nevét Kongói Demokratikus Köztársaságra változtatta. Kabila uralma azonban nem váltotta be a hozzá fúzött

\footnotetext{
${ }^{555}$ Szabó Loránd [2008]: Kongói Kaleidoszkóp 1998-2008: a hatalmi erőtér változásai. Külügyi szemle, 2008. (7. évf.) 4. sz. 119-139. old

556 Reyntjens, Filip. The Great African War [2009]: Congo and Regional Geopolitics, 1996-2006. Cambridge: Cambridge UP, 2009
} 
reményeket: 1997 szeptemberében betiltotta a politikai pártokat, a sajtó képviselőit folyamatosan zaklatták, és a romokban heverő gazdaságot sem sikerült talpra állítania.

Belföldön bábnak tekintették, akit a tutszik segítettek hatalomra külföldröl (hozzájárult ehhez a Kinshasában tartózkodó ruandai katonák jelenléte is), akinek döntéseit Ruandából és Ugandából diktálják. Ez ellen a látszat ellen próbált tenni Kabila, és 1998 közepére korábbi szövetségesei ellen fordult: elbocsátotta ruandai vezérkari fönökét, majd július 27-én kiutasította az országból a ruandai hadsereget. ${ }^{557}$

\subsubsection{Ruanda és Uganda egymás ellen fordul}

1998 augusztusában Uganda és Ruanda újabb kongói lázadók (nagyrészt Banyamulengékből álló Rassemblement Congolais pour la démocratie) támogatását kezdte el, ezúttal Laurent-Désiré Kabila elnök leváltását célozva.(Kelet-kongói felkelés) 1999 elejére már a lázadók és ugandai, valamint ruandai segítőik kezében volt a Kongói Demokratikus Köztársaság keleti része.

A két szövetséges, Ruanda és Uganda azonban már 1998-ban kezdett egymás ellen fordulni. A Kongói Demokratikus Köztársaság északnyugati részén 1998 végén alakult meg az Uganda-barát Movement for the Liberation of Congo nevü mozgalom (MLC).A Ruanda-barát Congolese Democratic Rally (RCD) nevü csoportosulás nem nézte jó szemmel az MLC megalakulását, és ellenségesen lépett fel az MLC-vel szemben, emiatt Ruanda és Uganda kapcsolata is feszültebbé vált. Uganda a ruandai és kongói szövetségeseitől függetlenül igyekezett befolyásolni az események alakulását a Kongói Demokratikus Köztársaságban. Kigali az MLC létrehozását nyílt kihívásnak, és az RCD befolyását féltette. ${ }^{558}$

1999 augusztusában a kelet-kongói Kisangani környékén ugandai és ruandai csapatok csaptak össze. 2000-ben ezt két újabb ugandai-ruandai csata követte. Az ugandai vezetés azzal vádolta Kigalit, hogy támogatja az ugandai disszidálókat, míg Ruanda az Interahamwe támogatásával gyanúsította Kampalát.

\footnotetext{
${ }^{557}$ Szabó Loránd [2008]

${ }_{558} \mathrm{Az}$ alapvető problémát az jelentette, hogy Paul Kagame ruandai elnök és a ruandai katonai vezetés nagy része évtizedekig Ugandában élt, 1994-es ruandai visszatérésükig. Sokan Museveni oldalán harcoltak az ugandai polgárháborúban, amíg 1986-ban Museveni átvette a hatalmat. Számos ruandai államférfi és magas rangú katona korábban az ugandai közigazgatásban és hadseregben töltött be magas rangú tisztséget. Museveni ezért mentornak és irányítónak tartotta magát, a ruandai vezetés azonban (bár hálás volt Museveninek a támogatásáért), egyenrangú partnerként való elismerést akart.
} 


\subsubsection{Afrika „világháborúja”}

Az 1998-ban kezdődött kelet-kongói felkelés fokozatosan kiszélesedett. Uganda és Ruanda segítségével az RCD-felkelök erőfölényükből adódóan valószínüleg gyorsan megbuktatták volna Kabilát, azonban Kabila segítségkérésére reagálva a regionális szolidaritás jegyében Namíbia, Zimbabwe és Angola támogatni kezdte Kinshasát. ${ }^{559}$ Később Csád és Szudán is bekapcsolódott a konfliktusba Kabila oldalán. Pierre Buyoya (Burundi elnöke) tutszi kormánya Ruandát és Ugandát támogatta Kabila ellenében.

Habár a rengeteg civil és katonai áldozatot követelő háború úgy tünt, a vége felé közeledik az 1999-ben aláírt lusakai egyezménnyel, Laurent-Désiré Kabila folyamatosan hátráltatta az egyezmény életbe léptetésének gyakorlati lépéseit. 2001. január 16-án azonban Kabilát meggyilkolta egyik testőre ${ }^{560}$, és a hatalmat fia, Joseph Kabila vette át. Közben az ENSZ több mint ötezer fös békefenntartó eröt (MONUC, United Nations Organization Mission in the Democratic Republic of the Congo) küldött Kongóba. (A létszámot azóta több mint húszezer före bővítették, ez a világon a legnagyobb létszámú ENSZ-erő). ${ }^{561} 2002$ nyarán, hosszas tárgyalások eredményeképpen sikerült elérni, hogy a kelet-kongói hutu milíciák lefegyverzésének ígéretéért ${ }^{562}$ cserébe Ruanda elkezdte a csapatkivonást a Kongói Demokratikus Köztársaság területéről (Pretoriai egyezmény). Ezzel párhuzamosan Uganda és Burundi is megkezdte a csapatkivonást Kongóból. ${ }^{563} 2002$ decemberében a kongóközi párbeszéd résztvevői (a konfliktusban részt vevő minden kongói fél) átfogó egyezményt írtak alá, 564 így a második világháború óta a legtöbb áldozatot követelő háború 2003-ra hivatalosan véget ért.

559 Ezek az országok a Dél-Afrikai Fejlesztési Közösség tagjai voltak, a Kongói Demokratikus Köztársasággal együtt, Forrás: Szabó Loránd: Kongó - Válsággóc Kelet és Nyugat között. Afrika tanulmányok, 2007. (1. évf.) 1. sz. 32-43. old.

560 The Economist, Obituary of Laurent Kabila, 18 January 2001. http://www.economist.com/node/481974, [2013.01.22]

${ }^{561}$ Forrás: MONUC Facts and Figures. http://www.un.org/en/peacekeeping/missions/monuc/facts.shtml [2013.01.22.]

562 2000-ben alakult meg az életben maradt radikális hutukból az FDLR (Forces démocratiques de libération du Rwanda), amely a tutszi befolyás elleni küzdelmet tűzte zászlajára, és föleg Kelet-Kongóban fejtette ki tevékenységét

${ }^{563}$ Braeckman, Colette [2003]: Les nouveaux prédateurs. Politique des puissances en Afrique centrale Éditions Fayard

${ }^{564}$ Szabó [2008] 
11. ábra A ruandai népirtás regionális hatása

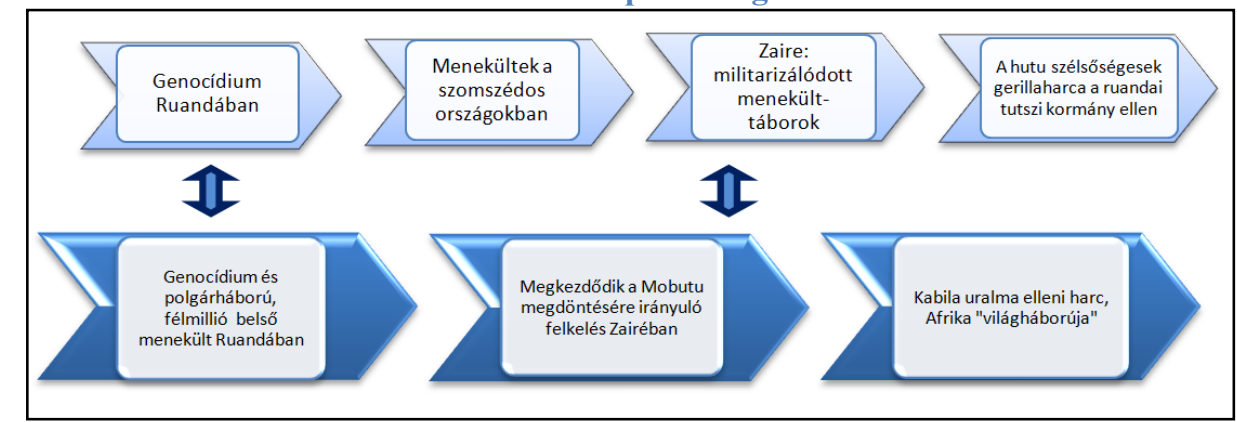

Forrás: saját szerkesztés

\subsection{9. Összefüggések a három népirtás között}

Általánosítva tehát megállapíthatjuk, hogy a disszertációban tárgyalt három esettanulmány szorosan összefügg. Az afrikai Nagy Tavak régió destabilizálódásához nagymértékben hozzájárult a burundi, ruandai és kongói genocídium. Hatásait a mai napig érzi a világ (elég, ha a közelmúltban a kelet-kongói Goma városát elfoglaló M23felkelőkről szóló hírekre gondolunk).

Mindhárom eset regionális következményekkel járt. Az 1972-ben Burundiban bekövetkezett népirtás hatására a határokon kívülre szorult hutu menekültek körében kikristályosodott a hutu identitástudat, nagy részben a közösnek tekintett ellenség, a tutszik identitásának ellenpólusaként. Liisa Malkki a tanzániai menekülttáborokban élő hutukkal készített interjúsorozatot a nyolcvanas években. Később megjelenő könyvében bemutatta a hutu menekültek gondolatvilágát, tutsziellenességét. ${ }^{565}$ Ugyanezek az eszmék jelentek meg Ruandában az 1994-es népirtás előtt a közvéleményt a tutszik ellen hangoló radikális Kangura c. újság cikkeiben és a Radio Mille Collines rádióadó müsoraiban. Kialakult az afrikai Nagy Tavak régió országaiban a közös hutu identitástudat, amelynek fontos részét képezték a tutszikkal szembeni negatív elöítéletek. Ezen közös mítoszok lényege az volt, hogy a tutszik minden országban, ahol jelen vannak, a hutuk leigázására, a saját hatalmuk kiterjesztésére törnek. ${ }^{566}$

A nemzetközi közösségben Burundi 1972-es népirtása kapcsán gyakorlatilag fel sem merült a beavatkozás, vagy legalább nyomásgyakorlás ötlete. Amerika nem ítélte elég fontosnak a Burundiban zajló eseményeket ahhoz, hogy érdemben állást foglaljon. Belgium éppen visszavonulóban volt a térségből, Franciaország pedig az opportunizmus

\footnotetext{
${ }^{565}$ Malkki, Liisa [1995]: Purity and Exile: Violence, Memory, and National Cosmology among Hutu Refugees in Tanzania, University of Chicago Press

${ }^{566}$ de Swaan, Abram [1997]: Widening circles of disidentification. On the Psycho- and Sociogenesis of the Hatred of Distant Strangers; Reflections on Rwanda. Theory, Culture \& Society 1997 (SAGE, London). Vol. 14 (2) 105-122.old.
} 
(frankofónia terjesztése) jegyében még segített is a tutszi elitnek a „felkelés leverésében”. Az afrikai országok államföi nagyobbrészt Burundi „magánügyének” tartották a hutuk lecsendesítése érdekében bevetett eszközöket, sőt, Zaire még aktív katonai segítséget is nyújtott a Micombero-rezsimnek.

A nemzetközi közösség tehát elmulasztotta a lehetőséget, hogy az afrikai Nagy Tavak régió első huszadik századi népirtását megakadályozza. Igaz, hogy ebben az esetben viszonylag kevés felkészülési idő volt, mert a kívülállókat valószínüleg váratlanul érte, hogy az etnikai alapú diszkrimináció és az egyik etnikai csoport hatalomhoz való ragaszkodása népirtáshoz vezetett.

Teljesen más motivációjú és sokkal alaposabban előkészített volt a ruandai genocídium. Ruandában az 1961 után kormányzó hutu elit, valahányszor fenyegetve érezte magát, vagy belső ellentétekkel küzdött, kihasználta a társadalomban mélyen gyökerező tutsziellenes érzéseket hatalma megszilárdítására. ${ }^{567}$ Így jutott el a ruandai társadalom 1990-es évekre arra a szintre, hogy a tutszikat széles körben csótánynak, Inyenzinek nevezték és másodrendü állampolgároknak tekintették őket. Az Ugandában megalakuló, ruandai tutszi menekülteket tömörítő RPF gerillatevékenysége nyomán kialakuló polgárháborús állapotok csak fokozták a feszültségeket a ruandai társadalmon belül. Egyre erőteljesebben körvonalazódott a „,végső megoldás”, az „,apokalipszis” a hutu radikálisok körében.

A nemzetközi közösség 1994-ben másodszor is hagyta a régióban megtörténni a genocídiumot, egy stratégiailag lényegtelennek ítélt afrikai országban, Ruandában. Ez a népirtás azonban szakértők szerint előre megjósolható volt. A megelözésére lett volna idő és alkalom.

Ehelyett a nemzetközi közösség a Ruandában állomásozó ENSZ-kontingens létszámát a népirtás közben csökkentette. Ruandát a Paul Kagame-vezette RPF-nek kellett „felszabadítania”. A népirtás hosszú távú hatása szempontjából ennél is súlyosabb hiba volt, hogy Franciaország szemet hunyt a megkésett Opération Turquoise biztonsági zónáin keresztül korábbi szövetségese, a Habyarimana-rezsim elkövetőinek Zairéba menekülése fölött.

A népirtás után megindult menekültáradat miatt avatkozott be Ruanda, és hajtotta végre az 1996-os zairei népirtást a menekülttáborokban. Közben megbuktatta Mobutut,

\footnotetext{
${ }^{567}$ Uvin, Peter [1999]: Ethnicity and Power in Burundi and Rwanda- Different paths to mass violence Comparative Politics, Vol. 31, No. 3
} 
és Ugandával és Burundival együtt hatalomra segítette Laurent-Désiré Kabilát. Amikor Kabila korábbi szövetségesei ellen fordult, megkezdődött „Afrika világháborúja”.

A nemzetközi közösség valószínüleg a zairei népirtást is megelőzhette volna, ha a militarizálódott menekülttáborokban az elkövetőket a bona fide menekültektől elválasztja.

A disszertációban tárgyalt három esettanulmány jól példázza, hogy az afrikai Nagy Tavak régió országait nem lehet egymástól függetlenül kezelni, mert egy regionális biztonsági komplexumot ${ }^{568}$ alkotnak. Barry Buzan "Az emberek, az államok és a félelem" címü 1983-ban megjelent tanulmányában ${ }^{569}$ vezette be a regionális biztonsági komplexum (RSC) fogalmát, amely olyan államok csoportja, amelyeknek a biztonsággal összefüggő problémáik annyira szorosan kötődnek egymáshoz, hogy azokat nem lehet egymástól függetlenül értelmezni. A biztonsági komplexum elmélete szerint a nemzetközi rendszer szereplői befolyással vannak egymásra, valamint függnek egymástól. Az államok közötti kapcsolatokban a befolyás és függőség intenzitását meghatározza a földrajzi távolság, mert a biztonságot vagy a hiányát előmozdító tényezők kisebb távolságra erősebben hatnak, mint nagyobb távolságra. ${ }^{570}$

Jelen esetben a genocídiumok jelentenek biztonsági kockázatot a vizsgált régióra: a genocídiumok egymáshoz kapcsolódó jellege és tovagyürüző hatása, a regionális interdependencia, a kölcsönös sebezhetőség érzékelése vezette az egy komplexumba tartozó országokat arra a felismerésre, hogy az egy országon belül zajló konfliktusok, köztük a népirtás, megfékezése és megoldása regionális választ kíván. A belföldi konfliktusok sok esetben, a fentiekben tárgyalt három esettanulmány során is, regionalizálódtak. A genocídiumok, valamint egyéb belföldi konfliktusok pusztító regionális hatása tehát regionális béke- és biztonsági rendszerek kiépítését teszik szükségessé.

A világon több olyan régió van, ahol vissza-visszatérnek bizonyos konfliktusok, ezzel destabilizálva az adott régiót. A Nagy Tavak Régió destabilizálódása egyszer már beszippantotta nemcsak közvetlen környezetét, hanem Afrika nagy részét is, globális problémákat és bizonytalanságot kiváltva.

\footnotetext{
${ }^{568}$ Francis, David J. [2006].: Uniting Africa: Building Regional Peace and Security systems, 103.old. Ashgate Publishers

${ }^{569}$ Barry Buzan [1983]: People, States \& Fear: The National Security Problem in International Relations, Wheatsheaf Books

${ }^{570}$ Buzan, Barry, Weaver, Ole, de Wilde, Jaap [1998]: Security: A New Framework for Analysis. Lynne Rienner Publisher
} 
A biztonsági kihívások egymással szorosan összefüggenek, és mindegyik kezelése, vagy éppen elhanyagolása hatással van más biztonsági kockázatokra. ${ }^{571}$ Tehát ahogy a disszertációban vizsgált esettanulmányokból leszürhetjük, még egy stratégiailag lényegtelennek tünő, kis afrikai ország esetében is fontos lehet egy népirtás megelőzése, akár a globális biztonság szempontjából is.

\subsection{Ajánlások a hatékony megelözésért}

Az ENSZ Genocídium-egyezménye kötelezi a részes államokat, hogy tegyenek lépéseket a megelőzés és a felelősségre vonás érdekében. E két kötelezettség közül jelentős előrelépés tapasztalható a genocídium miatti felelősségre vonás ügyében, de a megelőzés összefüggő, hatékony nemzetközi intézményrendszerét még nem sikerült kialakítani.

A probléma orvoslása érdekében a következő ajánlások születtek:

1. A népirtások hatékony megelőzéséhez regionális „fókuszpontokra" van szükség a világ különböző pontjain, amelyek feladata az információgyűjtés és értékelés mellett ajánlások készítése lenne a döntéshozók számára.

2. A Genocídium-egyezményből fakadó kötelezettségek betartása érdekében kikényszerítő intézményrendszer kialakítására van szükség. A tagországok független szakértőiből álló testület feladata a részes államok szerződésből eredő kötelezettségeinek bizonyos, meghatározott időközönkénti felülvizsgálata lenne.

Az elmúlt években számtalan szervezet foglalkozott világszerte a népirtásmegelőzéssel. Ezek az entitások azonban általában nem koordinálják egymással munkájukat, és nem dolgoznak szervezetten együtt egy szerteágazó és hatékonyan müködő rendszer kiépítése érdekében. Ezért lenne szükség új struktúra kiépítésére, amelynek lényege, hogy az egymással együttmüködő regionális fókuszpontoknak operacionális (rövid távú) és strukturális (hosszú távú) eszközök is rendelkezésükre állnak a megelőzésre. Minden fókuszpont fő feladatai közé tartozna, hogy a saját régiójából adatokat gyüjt és analizál, folyamatosan ellenőriz bizonyos

\footnotetext{
${ }^{571}$ Kondorosi Ferenc [2008]: A világ végveszélyben? A nemzetközi jog új kérdései, Budapest, Magyar Közlöny Lap- és Könyvkiadó
} 
„robbanásveszélyes” helyzeteket, ajánlásokat készít a döntéshozók számára, amelyek lehetővé teszik, hogy az események eszkalálódását elkerüljék. ${ }^{572}$

\subsubsection{Regionális megelőzés az afrikai Nagy Tavak régióban}

Az előző hipotézist igazoló részben megállapítottam, hogy a genocídium hatására regionalizálódó konfliktusok regionális béke- és biztonsági rendszerek kiépítését teszik szükségessé. A nemzetközi biztonság koncepciójában és gyakorlatában is tükröződik az a felismerés, hogy a biztonság területén az államok kölcsönösen függenek egymástól, csak együttmüködve képesek fenntartani a közös biztonságot. ${ }^{573}$ Ezt a felismerést magáévá tette a disszertációban tárgyalt régió több országa is. Az alábbiakban a Nagy Tavak régió kezdeti stádiumban lévő népirtás-megelőzési rendszerét megszervezni igyekvő regionális „fókuszpont” tevékenységébe és elképzeléseibe kaphatunk betekintést.

Az afrikai Nagy Tavak régió kilencvenes években tapasztalt, regionálissá szélesedő konfliktusainak megoldására született meg az International Conference on the Great Lakes Region (Nagy Tavak régiójával foglalkozó nemzetközi konferencia (ICGLR) nevü nemzetközi szervezet. Az 1997. február 18-án elfogadott 1097.ENSZ-BT határozat arra kérte a Nagy Tavak régió konfliktusaiban érintett feleket, hogy próbálják meg fegyveres harcaikat politikai párbeszéd és egy, az afrikai Nagy Tavak régió békéjéröl és biztonságáról rendezett nemzetközi konferencia keretében rendezni. ${ }^{574}$ Az EU Nagy Tavak Régiójába kinevezett különleges képviselője szintén a regionális megoldás mellett érvelt ${ }^{575}$ : „Modellünk az Európai Biztonsági és Együttműködési Értekezlet (EBEÉ), amely nagyban hozzájárult a béke és biztonság megszilárdulásához az Öreg Kontinensen. A cél az, hogy a régió országai között, valamint a régió és a nemzetközi közösség többi része között egy új együttmüködés alapjait rakjuk le."

A Nagy Tavak régió országainak körében is megerösödött az a nézet, hogy a külső segítség helyett (amely gyakran nem vagy csak későn érkezett) maguk igyekezzenek orvosolni saját konfliktusaikat. A regionális megoldás azért is kerülhetett előtérbe, mert

\footnotetext{
${ }^{572}$ Le Fevre, Cervini, Enzo Maria, Lakatos, István [2009]: The construction of a global architecture for the prevention of genocide and mass atrocities, 149-153.old. In: Politorbis No.47.- Genocide Prevention http://www.eda.admin.ch/etc/medialib/downloads/edazen/doc/publi/publi2.Par.0095.File.tmp/Politorbis\% 2047\%20-\%20Genocide\%20Prevention.pdf_[2013.01.31.]

${ }^{573}$ Matus János [2005]: A biztonság és a védelem problémái a változó nemzetközi rendszerben Hadtudomány, 2005/4.

${ }^{574} \mathrm{http}: / /$ www.un.org/ga/search/view_doc.asp?symbol=S/RES/1097(1997)_[2013.01.30.]

575 Ajello, Aldo [2000], Cavalier de la paix: quelle politique européenne commune pour I'Afrique? Brussels: GRIP, 2000, 105
} 
számos népcsoport a régió több országában is jelen van, ezek a csoportok kapcsolatban állnak egymással és ez növelheti az instabilitás terjedésének kockázatát egyik országról a másikra. (Például a Banyamulengék Kelet-Zairéban tutszi eredetűek, fenyegetettségükben pedig a szomszédos Ruandában kerestek tutszi szövetségest) ${ }^{576}$

2003-ban kezdődött meg az első Nemzeti Egyeztetés (National Coordination) hat, ún. magország között (Burundi, Kongói Demokratikus Köztársaság, Kenya, Ruanda, Tanzánia és Uganda), majd hozzájuk csatlakozott 2004-ben öt további ország: a KözépAfrikai Köztársaság, a Kongói Köztársaság, valamint Szudán ${ }^{577}$ és Zambia. ${ }^{578}$

A tizenegy tagállam 2005-ben kezdte meg egyeztetéseit, amelyek eredménye a 2006 decemberében, Nairobiban, Kenyában állam- és kormányfők által aláírt Béke, Stabilitás és Fejlődés Paktuma. A Paktum szerződéses formában is rögzítette a régió országainak hosszú távú együttműködési szándékát. ${ }^{579}$

A jegyzőkönyvek közül e disszertáció szempontjából különösen releváns a Népirtás, Háborús és Emberiesség Elleni Büncselekmények, valamint a Diszkrimináció Minden Formájának Megelőzéséről és Megbüntetéséről Szóló Jegyzőkönyv. ${ }^{580}$

A Jegyzőkönyv betartását egy 2010-ben, Kampalában alapított Regionális Bizottság hivatott ellenőrizni. A Bizottságba minden ICGLR-tagállam egy szakértőt delegál, akinek feladata a jegyzőkönyv életbe léptetésének koordinálása a saját tagállamában. Az egyes tagállamok maguk is alapítanak egy szervezetet, melynek feladata a nemzeti szintü koordináció, neve Nemzeti Bizottság. ${ }^{581}$

Az ICGLR háromszintü megelözési rendszere

\footnotetext{
${ }^{576}$ Kempf, Isabell [2012]: Bridging the Great Lakes, Implementing the human rights dimension of the International Conference on the Great Lakes Region, In: Regional dimensions of Conflict in the Great Lakes, ISS Workshop Report, 2012

577 2012. november 24-én csatlakozott a Konferenciához Dél-Szudán, ezzel a tagállamok száma tizenkettőre növekedett. Forrás: http://www.genprev.net, [2013.01.28.]: With South Sudan, ICGLR Now Has 12 Member States

${ }^{578}$ https://icglr.org/spip.php?article1[2013.01.30.]

${ }^{579}$ https://icglr.org/IMG/pdf/Pact_on_Security_Stability_Development-S.pdf [2013.01.30.]

580 A jegyzőkönyv szövege az 1948.évi Genocídium-egyezmény szerinti népirtás-definíciót fogadja el irányadónak. „Az ICGLR-tagállamok [...] elismerik, hogy a népirtás, háborús és emberiesség elleni büncselekmények nemzetközi jogi büncselekménynek minősülnek és felvállalják, hogy

a) Tartózkodnak tőle, megelözik és megbüntetik

b) Elítélik és küzdenek a diszkrimináció és diszkriminatív gyakorlatok minden formája ellen

c) Biztosítják a fentiek szigorú megfigyelését minden nemzeti, regionális és helyi hatóság és intézmény által

d) Betiltanak minden olyan propagandát és szerveződést, amely valamely rassz vagy etnikai csoport felsőbbrendűségét hirdeti, vagy amely igazolni próbálja vagy bátorítja az etnikai, vallási, rassz- vagy nemi alapú gyülöletet vagy diszkriminációt” (Idézet a Paktum 8. cikkelyéből)

${ }^{581}$ https://icglr.org/spip.php?article2, [2013.01.28.]
} 
Az ICGLR saját bevallása szerint az afrikai Nagy Tavak régió országainak tanulniuk kell azoktól az országoktól, amelyek sikerrel emelkedtek felül hasonló múltjukon, és pozitív gyakorlatukat fel kell használniuk a megelőzésben a jövőben. Az ICGLR szakértői 2012 májusában kiadott tájékoztató füzetükben azonban azt is hangsúlyozzák, hogy „,semmilyen egyéb népirtás-megelőzési rendszer nem müködik jelenleg”, ${ }^{582}$ tehát a szervezet kezdeményezése egyedülálló.

Az ICGLR szakértői megállapítják, hogy a népirtás-megelőzés nem történhet kizárólag a nemzetközi közösség segítségével: a regionális szervezetekbe tömörült országok kollektív erőfeszítése, valamint a vidéki(falusi) közösségek elkötelezettsége is szükséges. A helyi közösségek a Nagy Tavak régióban sok esetben tömeges erőszak elszenvedői voltak, így készek az együttmüködésre a hasonló helyzetek elkerülése érdekében. Az ICGLR tehát olyan jellegű népirtás-megelőzési rendszer kiépítését tüzte ki célul, amely összekapcsolja a helyi, nemzeti és regionális szinteket.

Az ICGLR szakértői úgy vélik, hogy évekig tarthat, mire ezt a rendszert sikerül kiépíteni. A siker érdekében az ICGLR szorosan együttmüködik az ENSZ népirtásmegelőzési és védelem felelősségére koncentráló különleges megbízottjával is. 2010. augusztus 9-én interaktív párbeszéd formájában tárgyalták meg a régió országai a védelem felelősségének szerepét a regionális és szubregionális szinteken. Az ICGLR akkori főtitkára, valamint Francis Deng népirtás-megelőzési különleges megbízott együttesen kijelentették, hogy a régió elkötelezett a megelőzés rendszerének kiépítése mellett.

De hogyan valósítaná meg az ICGLR a gyakorlatban ezt a háromszintü megelőzési rendszert? Először is nyilvánvaló, hogy a megelőzés sikeressége attól függ, hogy nemzeti, illetve helyi szinten sikerül-e átültetni az elveket a gyakorlatba. A Regionális Bizottság eleinte nem új struktúrák alapításával, hanem meglévő kormányzati és önkormányzati intézményekkel ${ }^{583}$ való együttműködéssel biztosítaná a célok elérését.

A következő táblázat azt illusztrálja, hogy a megelőzési rendszerben melyik szereplőnek milyen konkrét feladatot kell ellátnia:

\footnotetext{
${ }^{582}$ http://www.genprev.net/wp-content/uploads/2012/05/First-Booklet-English-and-French.pdf 583 Ilyenek lehetnek többek között a nemzetbiztonsági szervezetek, a jog betartását ellenőrző intézmények, emberi jogi szervezetek, közoktatási intézmények, civil szervezetek, kulturális intézetek
} 
1. táblázat A megelőzési rendszerben ellátandó feladatok az egyes szereplők esetében

\begin{tabular}{|c|c|}
\hline $\begin{array}{l}\text { A tagállamok } \\
\text { kormányai }\end{array}$ & $\begin{array}{l}\text { a) beépítik a hazai jogrendbe a megelözésről szóló } \\
\text { jegyzőkönyvet } \\
\text { b) anyagi és egyéb szükséges támogatást biztosítanak a } \\
\text { Regionális Bizottságnak és Nemzeti Bizottságnak a } \\
\text { jegyzökönyvhöz kapcsolódó programok és tevékenységek } \\
\text { megvalósításához }\end{array}$ \\
\hline Regionális Bizottság ${ }^{54}$ & 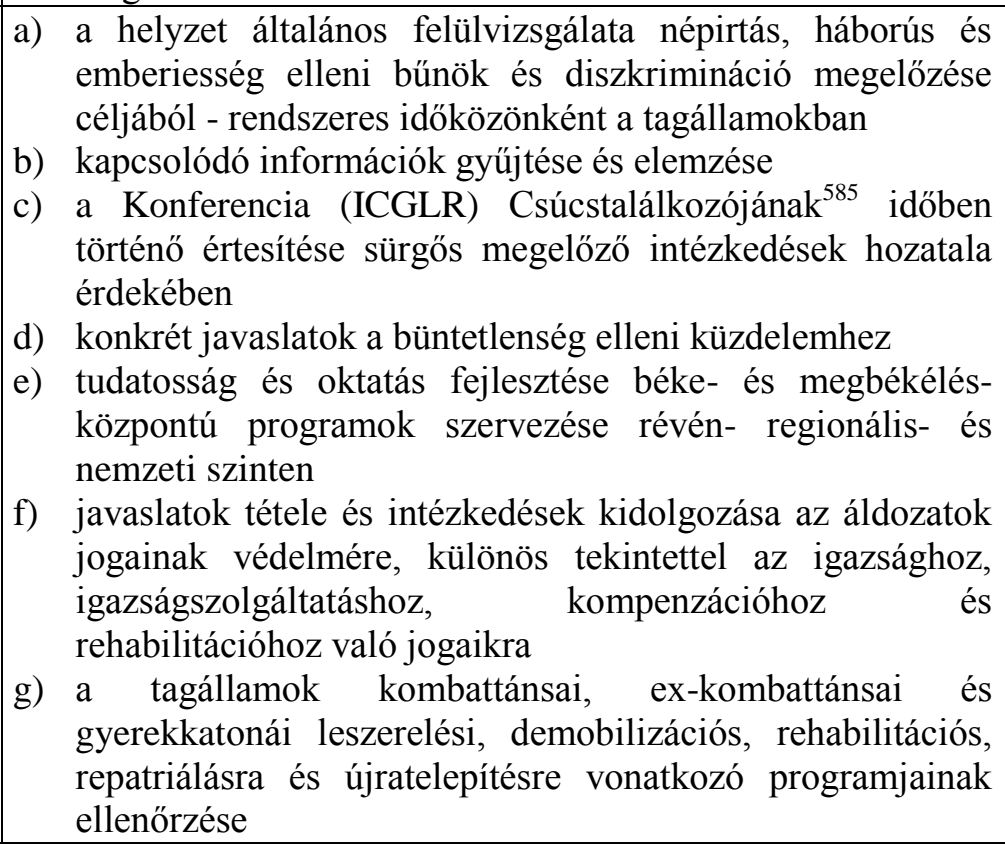 \\
\hline Nemzeti Bizottságok & $\begin{array}{l}\text { A Regionális Bizottság feladatainak teljesítése nemzeti } \\
\text { szinten. }\end{array}$ \\
\hline ICGLR Titkárság & $\begin{array}{l}\text { A Jegyzőkönyv betartását lehetővé tévő tevékenységek és } \\
\text { programok végrehajtásának biztosítása, ellenőrzése, } \\
\text { koordinációja, elösegítése }\end{array}$ \\
\hline $\begin{array}{l}\text { Partnerek, különféle helyi } \\
\text { és civil szervezetek }\end{array}$ & $\begin{array}{l}\text { a) kutatás, tréningek, publikációk } \\
\text { b) a Regionális, Nemzeti és helyi bizottságok munkájának } \\
\text { segítése }\end{array}$ \\
\hline
\end{tabular}

Forrás: Conference Secretariat of the International Conference on the Great Lakes Region (2012) alapján

A fentiekben felvázolt struktúra természetesen csak kiindulópont a népirtások jövőbeni megelőzéséhez. Az ICGLR legfontosabb hiányossága egyelőre, hogy nem áll rendelkezésére elegendő képzett munkaerő és anyagi forrás. A régióban jellemző magas szegénységi, valamint analfabetizmus-ráta szintén nehézkessé teszi, hogy az emberekben tudatosítsák a visszatérő erőszak okait és felvértezzék őket az esetleges manipuláció ellen, hogy a tehetetlenségböl aktív, önmagukat, a környezetüket, a társadalmat alakító helyzetbe kerüljenek a helyi közösségek.

\section{Korai figyelmeztetés (early warning)}

\footnotetext{
${ }^{584}$ A Jegyzőkönyv 38. cikkelye alapján

${ }^{585}$ Csúcstalálkozó (a Paktum meghatározása szerint): a tagállamok államfőiből és kormányaiból delegált testület
} 
Ahogy a disszertáció első részében már említettem, a népirtás-megelőzésben a problémát általában nem a korai figyelmeztetés hiánya jelenti, hanem az, hogy a figyelmeztetés után nem sikerül eltéríteni az eseményeket eredeti irányuktól.

Az ICGLR erre a hiányosságra az EWR (Early Warning and Proper ResponseKorai Figyelmeztetés és Megfelelő Válasz) rendszerét dolgozta ki: ez a rendszer lehetőséget ad arra, hogy a konfliktusokat időben észleljék a döntéshozók, és határozott megelőző lépéseket kezdeményezzenek. Az EWR a Regionális Bizottságon belül müködik a következő módon:

1. Felméri az egyes régiók különböző igényeit, a figyelmeztetendő „célközönséget” (a veszélyeztetett célcsoport vagy a Nemzeti Bizottság, esetleg a döntéshozók is beletartozzanak-e)

2. Összehangolja a várakozásokat, reális célokat tűz ki (a Regionális Bizottság feladata, hogy a cselekvés főbb pontjait kidolgozza: a következő lépés mindig legyen világos, és a válasz összességében gyors)

3. A helyi értelmiség (ök legyenek az ICGLR „,szeme és füle”) tudását igyekszik beépíteni a döntéshozatalba

4. Alapelvei az átláthatóság és elszámoltathatóság: minden egyes, a második pontban meghatározott lépésnek van felelőse, aki maga is ún. „fókuszpont” (például egy konkrét kormánytisztviselő), aki elszámoltatható az adott megelőző lépés bekövetkeztéért

Ez az alulról építkező béketeremtés, amelynek lényege, hogy a társadalom és a kormányzat minden szegmensét bevonják a megelőzésbe, teljesen új szemléletet jelent a korábbi békepaktumokhoz képest. Az ICGLR tagjai által aláírt paktum a regionális koordináció programja, amely új alapokra helyezheti a népirtás megelőzését is: egyrészt a helyi-nemzeti-regionális háromszintü rendszer kiépítésén keresztül, másrészt a korai figyelmeztetés rendszerének bevezetésével. 


\subsubsection{Magyarország szerepe a népirtás-megelőzésben}

\section{Budapesti Központ a Népirtás és Tömeges Atrocitások Nemzetközi Megelőzéséért}

Egy másik újszerü nemzetközi kezdeményezés a Budapesti Központ a Népirtás és Tömeges Atrocitások Nemzetközi Megelőzéséért.

2006-ban az Európai Unió szakértői bizottságot alapított, hogy a testület népirtásés tömeges emberi jogi jogsértések megelőzését célzó kapacitások bővítésére tegyen javaslatokat. ${ }^{586}$ A David Hamburg népirtás-megelőzési szakértő által elnökölt bizottság azt javasolta Javier Solanának (az Európai Unió akkori közös kül- és biztonságpolitikai főképviselője), hogy Európában hozzanak létre egy Nemzetközi Központot a Népirtás és Emberiesség Elleni Bűncselekmények Megelőzéséért.

2007 júliusában, Javier Solana felkérte a biztonságpolitikai kérdésekkel foglalkozó Madariaga Európai Alapítványt, ${ }^{587}$ hogy dolgozza ki egy európai népirtás-, és emberiesség elleni büncselekmények megelőzésével foglalkozó központ akciótervét, a védelem felelősségének követelményeivel összhangban. A Madariaga Alapítvány 2007 szeptemberében elindította a Népirtás- és Tömeges Emberi Jogi Jogsértések Megelőzéséért Európai Program előkészítő fázisát. ${ }^{588}$

Az Európai Unió körvonalazódó kezdeményezésére a magyar kormány aktívan reagált, és 2008-2009-ben megvalósíthatósági tanulmányt készíttetett egy budapesti Központ létrehozásáró1. ${ }^{589}$

A megvalósíthatósági tanulmány eredményei alapján a Központ 2012 második felében kezdte meg működését. „A Központ fő célja a népirtások és tömeges emberi jogi jogsértések megelőzésének folyamatában a korai figyelmeztetés és a gyors reagálás közötti ürt betölteni." ${ }^{590}$ Ennek érdekében konkrét gyakorlati ajánlásokat tesz a

\footnotetext{
${ }^{586}$ Melynek tagjai voltak: Carter Központ, Folke Bernadotte Akadémia, Madariaga Európai Alapítvány és az Európai Unió akkori közös kül- és biztonságpolitikai föképviselőjének delegáltjai.

${ }^{587}$ Az Alapítvány fő célja az Európai Unió változó szerepének definiálása változó világunkban. Ennek érdekben kutatási és gyakorlati projekteket is finanszíroz, amelyek Európa szerepének felértékelését, valamint a konfliktusmegelőzést célozzák.

${ }^{588}$ Le Fevre, Cervini, Enzo Maria, Lakatos, István [2009]

${ }^{589}$ Megvalósíthatósági Tanulmány a Budapesti Népirtás Megelözési Nemzetközi Központ létrehozásáról http://www.kulugyminiszterium.hu/kum/hu/bal/Kulpolitikank/emberi_jogok_vedelme/bp_nepirtas_megel ozesi_kozpont/ [2013.01.31.]

590 „Az új intézmény erőfeszítéseinek központjában a korai elörejelzés és a gyors fellépés közötti szakadék áthidalása fog állni a nemzetközi politikai szereplőknek nyújtott politikai és gyakorlati jellegü ajánlásai révén.” Forrás: Megvalósíthatósági Tanulmány a Budapesti Népirtás Megelőzési Nemzetközi Központ létrehozásáról.
} 
döntéshozók számára, amelyek lehetővé teszik a szükséges információkon alapuló, időben kezdődő és hatékony megelőzést. ${ }^{591}$

A Központ tehát integrált korai előrejelző és reagáló rendszert fog felállítani és müködtetni, amely elősegíti a gyors fellépéshez szükséges politikai konszenzus kialakítását nemzetközi és regionális szinten. ${ }^{592}$

Ezt a következő gyakorlattal igyekszik elérni: a Központ kutatói kidolgoznak egy általános kockázatértékelési metodológiát, valamint a megelőzésre szolgáló eszközök széles skáláját. Az egyes veszélyeztetett országokat periodikus országértékelésnek vetik alá. Az értékelést a terepen végzett kutatás és a regionális és civil szervezetektől, valamint különféle helyi partnerektől szerzett információk alapján készítik el. Ha az országértékelés alapján fennáll a népirtás esélye, akkor a további eszkaláció elkerülésére rövid-, közép- és hosszú távú ajánlásokat dolgoznak ki, amelyeket eljuttatnak a releváns döntéshozó szerveknek és személyeknek.

A Központ célja, hogy a nemzetközi közösséget mozgósítsa időben történő, hatékony és összeszedett fellépés érdekében.

Ezt a következő módon érné el: kapcsolati hálót építene ki egyrészt az ENSZ, Európai Unió, regionális és szubregionális szervezetek vonatkozó szerveivel, másrészt a döntéshozókkal.

A Budapesten található ENSZ Menekültügyi Főbiztosság Közép-európai Regionális Képviselete és Globális Szolgáltató Központja, Nemzetközi Migrációs Szervezet Regionális Irodája, Nemzetközi Vöröskereszt és Vörös Félhold Európa Zóna Irodája már komoly kapcsolati hálót jelent. Ezen kívül a Központ a következő regionális szervezetekkel épít ki kapcsolatot ${ }^{593}$ (a teljesség igénye nélkül): Afrikai Unió, ECOWAS (Nyugat-afrikai Államok Gazdasági Közössége), IGAD (Kormányközi Fejlesztési Hatóság- Kelet-Afrikában müködik hét állam részvételével), SADC (DélAfrikai Fejlesztési Közösség 15 taggal), ICGLR, ASEAN (Délkelet-ázsiai Nemzetek Szövetsége), Arab Liga, OAS (Amerikai Államok Szervezete), EBESZ, Európa Tanács.

A veszélyeztetett, valamint a megelőzésben részt vevő országok kormányával, illetékes tisztviselőivel, kutatóhálózatával szintén aktív kapcsolatok kialakítását tervezi a Központ.

\footnotetext{
${ }^{591}$ http://www.genocideprevention.eu/About.html [2013.02.01.]

592 Ibid.

${ }^{593}$ Le Fevre, Cervini, Enzo Maria, Lakatos, István [2009]
} 
A Központ prioritásai: ${ }^{594}$

1. akadémiai kutatás előkészítése és koordinálása (a népirtás- és tömeges emberi jogi jogsértések, védelem felelőssége és humán biztonság témaköreiben a nemzetközi jogi és nemzetközi kapcsolatok elméleti háttér kutatása)

2. mélyelemzések készítése a korai figyelmeztetés érdekében, szakmai beszélgetések szervezése

3. ismeretterjesztő és tudatosító kampányok szervezése a témakörben a releváns szervekkel együttmüködve

4. a megelőzéshez kapcsolódó oktatás, tanítás, kutatás és szociális munka támogatása

5. a Központ és a nemzetközi közösség közötti együttmüködés előmozdítása közös programok és események, valamint együttmüködési nyilatkozatok aláírása révén

6. adatbank létrehozása, amely magában foglalja azokat a nemzetközi, regionális, nemzeti és helyi intézményeket és szervezeteket, valamint egyéneket, akik a népirtás- és tömeges emberi jogi jogsértések megelőzése, korai figyelmeztetés és konfliktus-megelözés területén tevékenykednek (és elősegíti közöttük az együttmüködést)

A Központ egyik legfontosabb 2012-ben elkezdett projektje a Tömeges Atrocitások EU-szintű Megelőzésével Foglalkozó Munkacsoport létrehozása, amely vezető európai akadémikusokból, szakértőkből, és gyakorlati szakemberekből áll. A Munkacsoport célja, hogy hozzájáruljon ahhoz, hogy az EU a védelem felelősségét a gyakorlatba átültesse. A Munkacsoport jelenleg egy hosszabb lélegzetü anyagon dolgozik, amelynek eredményeit 2013 márciusában teszik közzé. A dokumentumban az Európai Unió már meglévő genocídium- és tömeges emberi jogi jogsértések megelőzését célzó eszközeit veszik számba, és javaslatokat tesznek, hogy az EU képes legyen a gyors és megfelelő válaszlépésekre, a megfelelő időben. A jelentés külön figyelmet fordít a preventív diplomáciára és a válságot megelőző elkötelezettségre a veszélyeztetett országokban. ${ }^{595}$

A Központ másik jelenleg is folyamatban lévő projektje a „Népirtás-megelőzés a gyakorlatban” címmel fut. Ez lényegében egy néhány havonta megrendezésre kerülő konferenciasorozat. Minden konferencián a téma szakértői a laikus közönség interaktív bevonásával vitatják meg a megelőzés gyakorlati aspektusait. Az első konferenciára

\footnotetext{
${ }^{594}$ http://www.genocideprevention.eu/Research_and_Cooperation.html

595 http://www.massatrocitiestaskforce.eu
} 
2011 októberében került sor, ekkor az afrikai Nagy Tavak régió együttmüködési stratégiáját vitatták meg és a kooperáció szerepét a jövő népirtásainak megelőzésében, a legutóbbi rendezvény 2012 novemberében a gyülöletbeszéd népirtásban betöltött szerepét vizsgálta (az internet és mobiltelefon korában). ${ }^{596}$

A fentiekben tehát vázoltam két népirtás-megelözési „fókuszpont” müködését. Véleményem szerint a népirtás-megelőzés globális rendszere akkor lehetne igazán hatékony, ha hasonló „fókuszpontok” alakulnának Dél-Amerikában, Ázsiában, valamint Afrika többi régiójában is. Ezek a fókuszpontok saját régiójuk történéseit ellenőriznék folyamatosan, és jó kapcsolatot ápolnának a régió döntéshozóival, valamint a nemzetközi szervezetek és nemzetközi közösség döntéshozóival is. A fókuszpontok rendszere veszély esetén, mint „riadólánc” funkcionálna, minden egység nyomást gyakorolna a saját döntéshozóira és kapcsolati hálójára a hatékony megelőzés érdekében, míg a helyszíni „fókuszpont” a veszélyeztetett országban a konfliktus gyors eszkalálódását igyekezne megakadályozni.

\subsubsection{A Genocídium-egyezmény elöírásai a megelőzés és felelősségre vonás tekintetében, javaslat ellenőrző szerv létrehozására}

Ahogy a Népirtás Büntettének Megelőzéséről és Megbüntetéséről Szóló Egyezmény neve is mutatja, kötelezi a részes államokat, hogy tegyenek lépéseket a népirtás megelőzés és a felelősségre vonás érdekében.

A két tengely közül a felelősségre vonás terén jelentős elörelépés történt az elmúlt két évtizedben. Ahogy az első fejezetben már említettem, az Egyezmény első „,jogi felhasználására" majdnem ötven évet kellett várni: 1993 márciusában került rá sor. ${ }^{597}$ Egy hónappal később azonban a Biztonsági Tanács már létre is hozta a volt Jugoszlávia területén elkövetett bünöket kivizsgáló ad hoc bíróságot, mint a genocídium büntettének tárgya szerinti hatáskörrel rendelkező és illetékes törvényszéket. ${ }^{598} 1994-$ ben, a ruandai népirtás után pedig a Biztonsági Tanács egy második ad hoc bíróságot is alapított az egyezményre apellálva. ${ }^{599}$

\footnotetext{
${ }^{596} \mathrm{http}: / / \mathrm{www}$. genocideprevention.eu/Initiatives.html

${ }^{597}$ Amikor is a Nemzetközi Bíróság (International Court of Justice) kiadott két, a Genocídiumegyezményen alapuló ideiglenes intézkedést, ld. 137. lábjegyzet

${ }_{598}$ UN Doc. S/RES/827(1993)

${ }^{599}$ UN Doc. S/RES/955(1994)
} 
Az azóta eltelt években rendszeresen hivatkoztak jogi ügyekben az egyezmény definíciójára, és a releváns joganyag folyamatosan növekedett. Az első népirtás tárgyában született elmarasztaló ítélet 1998-ban született. ${ }^{600}$

1998-ban újabb jogi előrelépés történt: a Nemzetközi Büntetőbíróság Római Statútuma minden szegmensében átvette az Egyezmény genocídium-fogalmát. ${ }^{601} \mathrm{~A}$ Római Statútum hatályba lépésétől kezdve, 2002. július elsejétől a Nemzetközi Büntetőbíróság minden tagállam területén, ${ }^{602}$ vagy állampolgára által elkövetett hatálya alá tartozó cselekmény, tehát népirtás esetén is felléphet, ha azt az illetékes állam nem tette. A Bíróság jelenleg hat ország kapcsán, ${ }^{603}$ tizenkét különböző ügyben vizsgálódik, eddig 18 letartóztatási parancsot adott ki. ${ }^{604}$ Több mint hatvan évvel a Genocídiumegyezmény aláírása után tehát megállapítható, hogy a népirtás büncselekményének ma már nemcsak elméleti megfogalmazása, hanem egyre jelentősebb bírói gyakorlata is van.

Tehát a genocídium miatti felelősségre vonás kapcsán egyre hatékonyabb nemzetközi intézményrendszer körvonalazódik, amely mellett az országok túlnyomó többsége elkötelezte magát. A felelősségre vonás azonban nem helyettesítheti a megelőzést.

Ha az Egyezmény szövegét tekintjük át megelőzés szempontjából, akkor azonnal szembetünik az első cikk, amelyben szerepel, hogy a genocídium megelőzését és megbüntetését az Egyezmény részes államai vállalják. ${ }^{605}$ Bár a cikk összekapcsolja a megelőzés és felelősségre vonás fogalmát, ez nem jelenti azt, hogy a felelősségre vonás elrettentő ereje miatt nincs szükség megelőzésre.

Ezt igazolja egy 2007-es Nemzetközi Bíróságon hozott ítélet szövege is, amelyet Bosznia-Hercegovina 1993-ban nyújtott be az ICJ-hez az akkori Jugoszláv Szövetségi Köztársaság ellen. ${ }^{606}$ A 2007-ben ebben az ügyben hozott ítélet ${ }^{607}$ megállapította, hogy

\footnotetext{
${ }^{600}$ Grünfeld, Fred; Huijboom, Anke [2007]: The failure to prevent genocide in Rwanda: the role of bystanders. Martinus Nijhoff Publishers, 20.oldal

601 Rome Statute of the International Criminal Court, Article 6: The crime of genocide. http://untreaty.un.org/cod/icc/statute/romefra.htm

${ }_{602}$ Jelenleg 121 részes állama van, The States Parties to the Rome Statute. http://www2.icccpi.int/Menus/ASP/states+parties/ [2013.02.07.]

${ }^{603}$ Kongói Demokratikus Köztársaság, Közép-afrikai Köztársaság, Uganda, Kenya, Szudán, Líbia

${ }^{604}$ ICC: The Court Today, Updated: 13 September, 2011 www.icc-cpi.int/ The Court Today

${ }^{605}$ „A Szerződő Felek megerősítik, hogy a népirtás függetlenül attól, hogy békében vagy háborúban követik el, a nemzetközi jogba ütköző büncselekmény és kötelezik magukat arra, hogy ellene megelözö rendszabályokat foganatosítsanak, elkövetését pedig megbüntetik." Forrás: 1955.évi 16. törvényerejü rendelet.

${ }^{606}$ Lamm Vanda [2003]: A délszláv háború újabb felvonása a Nemzetközi Bíróság előtt. A NATO bombázások ügye a Bíróság elött, http://www.balkancenter.hu/pdf/elemzes/lammv.pdf, [2012.01.25.]
} 
a genocídium megelőzésének „normatív és kényszerítő erejü” kötelezettsége különálló feladatkört jelent.

Az Egyezmény harmadik cikke az alapcselekményeken kívül négy kategóriát említ, amelyek szintén büntetendőek a népirtások kapcsán. Ezek a következők: népirtás elkövetésére irányuló szövetkezés; közvetlen és nyilvános felbujtás népirtás elkövetésére; népirtás elkövetésének kísérlete; népirtásban való bünrészesség. ${ }^{608} \mathrm{~A}$ bünrészesség kivételével ezek a kategóriák szintén az Egyezmény megelőző jellegét erősítik.

Az Egyezmény szövege tehát megfelelő kiindulópontot jelent, amennyiben a megelőzés kötelezettségének a részes államok eleget tesznek. Ennek érdekében a Genocídium-egyezményben foglaltak betartását folyamatosan ellenőrizni kellene. Jelenleg azonban nincs az Egyezményhez kapcsolódó kikényszerítő intézményrendszer. A legfontosabb emberi jogi tárgyú univerzális nemzetközi szerződések létrehozták a bennük foglalt emberi jogok tiszteletben tartásának ellenőrzésére szolgáló különböző ellenőrzési mechanizmusokat. ${ }^{609}$

Az ENSZ emberi jogi egyezményeinek hatékony végrehajtása érdekében a tagországok általában független szakértőkből álló testületeket állítanak fel a részes államoknak a dokumentumokból eredő nemzetközi jogi kötelezettségei figyelemmel kísérése céljából. ${ }^{610}$ Például az ENSZ A kínzás és más kegyetlen, embertelen vagy megalázó büntetések vagy bánásmódok elleni egyezménye által elöírt kötelezettségek betartására az egyezmény létrehozta az ENSZ Kínzás Elleni Bizottságát. ${ }^{611}$ Ezen bizottság jelentéstételi kötelezettségén kívül 2006-tól a kiegészítő jegyzőkönyv újabb ellenőrző mechanizmusokat hozott létre: az ENSZ mellett működő, független szakértőkből álló Megelőzési Albizottságot és a tagállamok által müködtetett „,nemzeti megelőző mechanizmusokat", 612

\footnotetext{
${ }^{607}$ International Court of Justice: Case concerning application of the convention on the prevention and punishment of the crime of genocide, Judgment of 26 February, 2007, http://www.icjcij.org/docket/files/91/13685.pdf

${ }^{608}$ 1955.évi 16. törvényerejü rendelet

${ }^{609}$ Haász Veronika, Szappanyos Melinda [2012]: Az ENSZ tagállamok emberi jogi helyzetét értékelő egyetemes időszakos felülvizsgálat (UPR). Föld-rész 2011. (4. évf.) 1. szám

${ }^{610}$ Haraszti Margit Katalin [2008]: A kínzás és az embertelen vagy megalázó bánásmód és büntetések tilalma az ENSZ és az Európa Tanács legfontosabb dokumentumaiban, valamint az állampolgári jogok országgyülési biztosának tevékenységében. ACTA HUMANA 19. évfolyam, 2008. 3. szám, 51.oldal

${ }^{611}$ Convention against Torture and Other Cruel, Inhuman or Degrading Treatment or Punishment Part II, Articles 17-24. http://www2.ohchr.org/english/law/cat.htm, [2011.09.20.]

${ }^{612}$ Optional Protocol to the Convention against Torture and other Cruel, Inhuman or Degrading Treatment or Punishment, Part II-III-IV., Articles 5-23, http://www2.ohchr.org/english/law/cat-one.htm, [2011.09.20.]
} 
A Genocídium-egyezmény azonban semmiféle konkrét előírást nem tartalmaz a végrehajtás ellenőrzésére vonatkozóan. Az Egyezmény szövegének első vázlata még vizsgálta egy ellenőrző mechanizmus beépítését, de az annak idején innovatívnak ható ötlet nem került be az Egyezmény végleges szövegébe. ${ }^{613}$ Azóta azonban számos emberi jogi egyezmény elöírásainak hatékony betartását segíti elő ún. megelőző szervek tevékenysége. A Genocídium-egyezménnyel kapcsolatban is időről időre felmerült egy hasonló szerv létrehozásának lehetősége, amelyet az évek során számos áldozat, aktivista, jogi szakértő és 2004-ben Stockholmban ötven ország képviselöi támogattak. KoFI ANNAN 2004-ben A Népirtás Megelőzéséért Nemzetközi Fórumon Stockholmban így nyilatkozott: „Javaslom, hogy akcióba lendülési képességeink javítása érdekében gondolkodjunk el néhány új ötleten. Például a Genocídium-egyezmény részes tagállamainak meg kellene fontolniuk egy Népirtás-Megelőzési Bizottság felállítását, amely meghatározott időközönként jelentéseket készítene és ajánlásokat tenne...Ilyen szervek léteznek más nemzetközi szerződések gyakorlati megvalósításának elősegítésére. Miért nincs a Genocídium-egyezményhez kapcsolódóan?"614

Sok ország azonban ellenzi az ellenőrző szerv létrehozását, és azzal érvelnek, hogy a szükséges feladatokat már ellátja a Népirtás-megelőzési különleges megbízott, illetve a Nemzetközi Büntetőbíróság.

Én nem értek egyet a kétkedőkkel: szerintem hatalmas előrelépést jelentene egy olyan szerv, melynek feladata az Egyezményben foglaltak betartásának ellenőrzése lenne. Tevékenysége mérföldkő lehetne: a különleges megbízott figyelmeztetésével együtt aktív részt vállalhatna a megelözésben, míg széles körben ismertetett ajánlásai révén nyomást gyakorolhatna a jövő népirtóira, akik nagyobb valószínüséggel térnének el tervüktől.

Az ellenőrző szerv létrehozására három lehetőség kínálkozik:

1. A kikényszerítő-ellenőrző szerv felállítása a legegyszerübben közgyülési határozattal oldható meg.

2. Ennél időigényesebb és bonyolultabb megoldás lenne fakultatív jegyzőkönyvet csatolni az eredeti egyezményhez. Ebben az esetben az eredeti Egyezmény aláíróitól függne, hogy magukra nézve kötelezőnek ismerik-e el a

\footnotetext{
${ }^{613}$ Implementing the Genocide Convention by Louise Arbour United Nations High Commissioner for Human Rights [2008], http://www.ohchr.org/EN/NewsEvents/Pages/DisplayNews.aspx? NewsID=8476\&LangID=E, [2012.02.29.]

${ }^{614}$ Press Release, SG/SM/9126, Genocide is threat to peace requiring strong, united action, SecretaryGeneral tells Stockholm International Forum, [2004.01.26.] www.preventgenocide.org /prevent/UNdocs/KofiAnnanStockholmGenocideProposals26Jan2004.htm, [2012.02.29.]
} 
jegyzőkönyvben foglaltakat, csatlakoznak-e a hozzá. Az ENSZ közgyülése például 1989-ben elfogadta a Polgári és Politikai Jogok Nemzetközi Egyezségokmányához füzött Második Fakultatív Jegyzőkönyvet, amely a halálbüntetés megszüntetését írja elő.

3. A legnehezebben járható út magának az Egyezménynek a módosítása lenne.

Bármelyik megoldást választja is a nemzetközi közösség, a lényeg, hogy megbízható, hiteles fórumot hozzon létre, amely objektíven értékeli, hogy a részes államok eleget tesznek-e az Egyezményben foglalt kötelezettségeiknek.

\section{A Népirtás-Megelözési Bizottság müködése $e^{615}$}

A Népirtás-Megelőzési Bizottság fő célja, hogy rendszeres időközönként minden részes államban ellenőrizze a Genocídium-egyezményben foglalt megelőzési kötelezettség betartását, és azt a részes államok közremüködésével fejlessze. A Bizottság csak azokban az államokban ellenőrizhetné a megelőzési kötelezettség betartását, amelyek a Genocídium-egyezmény részes államai, vagy ha fakultatív jegyzőkönyv formájában hozzák létre, akkor a jegyzőkönyvhöz csatlakozó országokban. (Tehát korántsem lenne olyan univerzális, mint az ENSZ tagállamok emberi jogi helyzetét értékelő egyetemes időszakos felülvizsgálat (UPR)

Ha feltételezzük, hogy a Népirtás-Megelőzési Bizottság a Genocídium-egyezményt aláíró minden tagállamban folytathatna ellenőrzést, akkor a következőképpen müködne:

Mivel az Egyezménynek jelenleg 142 részes állama van, első évben 47 (,a csoport”), második évben 47(,b csoport”), harmadik évben 48 részes államot(„,c csoport”)vonnának vizsgálat alá (az egyenlő esélyek biztosítása érdekében sorsolás határozná meg, hogy melyik évben melyik részes állam kerül sorra), így három év alatt minden részes állam végigmegy a procedúrán. Kivételt képeznének azok az országok, ahol az elmúlt harminc évben történt népirtás. Ezen országok minden évben vizsgálat tárgyát képeznék.

A folyamat során az ,a csoport” első vizsgálandó országában a helyzetet a csoportba tartozó másik 46 ország szakértőinek (egy ország három szakértőt küldhet) munkacsoportja tekintené át. ${ }^{616}$ A munkacsoportból sorsolással kiválasztanak három jelentéstevőt ('rapporteur'), akik különböző regionális csoportokból kerülnek ki. A

${ }^{615}$ Az ENSZ tagállamok emberi jogi helyzetét értékelő egyetemes időszakos felülvizsgálat (UPR) müködésének mintájára

${ }^{616}$ Human Rights Council resolution 5/1 of 18 June 2007, Annex, I. Fejezet, D., 2., 18. (a) pont 
három jelentéstevő feladata a vizsgálat megkönnyítése, koordinálása, és legfőképp a munkacsoport jelentésének elkészítése. ${ }^{617}$

A vizsgálat alá vont államnak maximum húsz oldal terjedelemben kell jelentést tennie a szakértőkből álló munkacsoportnak. A jelentésnek hat héttel a vizsgálati folyamat kezdete előtt el kell jutnia a munkacsoporthoz. A jelentésben a vizsgált állam részletesen megfogalmazza, hogy milyen kihívásokkal kell szembenéznie a népirtások megelőzése terén és milyen intézkedéseket hozott, hogy a problémákat orvosolja. Ha korábban már állt vizsgálat alatt az ország, akkor a jelentésnek tartalmaznia kell, hogy a három évvel korábban a munkacsoport által megfogalmazott ajánlásokból mit sikerült valóra váltani, és indokolni kell, hogy a mellőzött ajánlások meghiúsulásának mi az oka.

A három jelentéstevőnek szintén össze kell állítania egy jelentést a vizsgált országról. E jelentés a munkacsoport és a vizsgált ország közötti interakció folyamán körvonalazódik és a jelentés végső formába öntött változata előtt a munkacsoport kérdéseket és megjegyzéseket tehet a vizsgált államnak. A vizsgált állam a hozzá intézett kérdésekre a maximum kétórás interaktív párbeszéd folyamán válaszolhat. A jelentéstevők feladata a kommunikáció pártatlanságának és átláthatóságának biztosítása.

Az interaktív párbeszéd után maximum két héttel (a vizsgálat maximum négy hetet vehet igénybe) a munkacsoport közzéteszi jelentését, végső következtetéseit. A munkacsoport jelentése a vizsgált állam számára következtetéseket, ajánlásokat tartalmaz, valamint a vizsgálat alatt álló állam önkéntes kötelezettségvállalásait. A jelentés összegzi a népirtás-megelőzés aktuális helyzetét, fejlesztésének lehetőségeit, más államok népirtás-megelőzéssel kapcsolatos gyakorlatának olyan elemeit, amelyek az adott államban alkalmazhatók, és az esetleges további konzultáció, technikai segítségnyújtás részleteit. ${ }^{618}$

Legalább ugyanilyen fontos, hogy a vizsgálat lefolytatása után sikerüljön az ajánlások implementációja. A Bizottság részes államai erről akár időszakos jelentést is benyújthatnak (nem kell feltétlenül három évet várniuk a következő felülvizsgálati folyamatra). ${ }^{619}$

A Bizottság az implementációt szakértők és gyakorlati segítségnyújtás útján is megkönnyítheti.

\footnotetext{
${ }^{617}$ Ibid., (d) pont

${ }^{618}$ Haász, Szappanyos [2012]

${ }^{619}$ Természetesen a „,b csoport” és „,c csoport” vizsgálati folyamata is a fenti minta alapján zajlana.
} 
A vizsgálat lefolytatásának költségét (szakértők, delegáltak helyszínre utazása), valamint az ajánlások megvalósításának technikai és anyagi hátterét a Bizottság egy önkéntes alapból finanszírozná, amelyet a fejlettebb tagországok felajánlásaiból tart fenn. Mivel a népirtások megelőzése az egész világnak érdekében áll, a felajánlások remélhetőleg folyamatosan érkeznek majd és elegendő fedezetet jelentenek.

\section{Zárszó}

A dolgozatban tett javaslatok talán utópisztikusnak tünhetnek az Olvasó számára. Párhuzamot vonva a rabszolgaság intézményével, ami ma már csak sporadikusan fordul elő, van remény arra, hogy a népirtások megelőzésében is jelentős elörelépés történjen.

Akárcsak a népirtások, a rabszolgaság is végigkísérte az emberiség történetét. Napjainkban azonban a világ nagy részén már sikerült jelentős mértékben visszaszorítani, ${ }^{620}$ globálisan a rabszolgaság aránya a teljes lakossághoz mérten mintegy 3-5 ezrelék körül mozog (Spártában az i.e. 5. században 8 ezer szabad emberre 200 ezer helóta jutott: ez kb. 96\%-ot jelent, az Egyesült Államokban a polgárháború idején 11\% volt ez az arány). ${ }^{621} \mathrm{Nem}$ is olyan régen még az élet természetes rendjéhez tartozott, hogy vannak szabadok és vannak rabszolgák.

A Yale Egyetem történészprofesszora, David Brion Davis munkásságát a rabszolgaság kutatásának szentelte. Egyik legjelentősebb müvében kiemelte, hogy a rabszolgaság eltörlése terén elért példátlan „erkölcsi eredménynek” a más alapvető társadalmi változásokért küzdő mozgalmak céljaiba vetett hitet is táplálnia kell. Nem szabad elfogadnunk a világot olyannak, amilyen. ${ }^{622}$

A nemzetközi összefogás hatására van remény a népirtások megelőzésére és remélem az én javasalataim is hozzájárulhatnak ahhoz, hogy a népirtások problémája előbb-utóbb megoldódjon.

\footnotetext{
${ }^{620}$ Hamburg, David [2010], 287.old.

${ }^{621}$ www.antislavery.org, [2013.01.20.]

${ }^{622}$ David Brion Davis [2006]: Inhuman Bondage: The Rise and Fall of Slavery int he New World, New York: Oxford University Press, 2006, 331.old.
} 


\section{Irodalomjegyzék}

\section{Esszék, monográfiák, tanulmányok}

Achieng, Judith [2000]: Sudan's protracted war, ICG News Desk

Adelman [2009]: The Role of Non-African States in the Rwandan Genocide Centre for Refugee Studies, York University

Adelman, Howard and Suhrke, Astri [1996]: Early Warning and Response: Why the International Community Failed to Prevent the Genocide, Disasters: The Journal of Disaster Studies and Management 20.4 (December 1996): 295-304.o.

Adelman, Howard and Suhrke, Astri [2000]: The Path of a Genocide: The Rwanda Crisis from Uganda to Zaire. Transaction Publishers, New Jersey

Adelman, Howard, Govind, Rao [2004]: War and Peace in Zaire-Congo: Analyzing and Evaluating Intervention, 1996-1997

African Rights (1995): Rwanda- Death, despair and defiance

Ajello, Aldo [2000], Cavalier de la paix: quelle politique européenne commune pour I'Afrique? Brussels: GRIP, 2000, 105

Amnesty International [2004]: Darfur: Rape as a Weapon of War: Sexual Violence and its Consequences

Apiku, Simon [2007]: African Darfur Troops Must Meet UN Standards- Adada, Reuters

Arnold, Guy [2009]: The A to Z of Civil Wars in Africa, 415.old. Scarecrow Press

Bakri, Nada [2011]: As Syria Urges Local Voting, U.N. Puts Toll From Clashes Past 5,000, 12 December, 2011, http://www.nytimes.com/2011/12/13/world /middleeast/clashes-reported-even-as-syria-urges-local-voting.html?_r=1

Baldauf, Scott [2007]: Sudan: Climate Change Escalates Darfur Crisis, The Christian Science Monitor

Barnett, Michael N. [1996]: The Politics of Indifference at the United Nations and Genocide in Rwanda and Burundi in: Cushman, Thomas and Mestrovic, G. Stejepan: This Time We Knew: Western Responses to Genocide in Bosnia, pp. 128-162, New York University Press

Bartrop, Paul R. and Jacobs, Steven L. [2011]: Fifty key thinkers on the Holocaust and Genocide, Routledge, New York

Bassir-Pour, Afsane [1996]: Washington freine toujours l'envoi d'une force multinationale au Zaire, 1996. november 11. , Le Monde

Bauer, Yehuda [1984]: Jewish foreign policy during the Holocaust. New York

Bauer, Yehuda [1991]: Holocaust and Genocide: Some Comparisons In: Lessons and Legacies: The Meaning of the Holocaust in a Changing World, ed. Hayes, Peter [1991] Northwestern University Press

Bauman, Zygmunt [1989]: Modernity and The Holocaust. Ithaca, N.Y.: Cornell University Press 
Bellamy, Alex J.[2010]: The Responsibility to Protect- Five Years On Ethics and International Affairs,24, No. 2., 143-169.o. Carnegie Council for Ethics in International Affairs

Benkes Mihály István [2004]: A kongói válság történeti gyökerei - a mobutizmus politikai hagyatéka. Kül-Világ, I. évfolyam 2004/1

Bezy, Fernand [1990]: Rwanda 1962- 1989, bilan socio- économique d'un régime, université catholique de Louvain, Institut d'Etudes du Développement, Louvain

Bloxham, Donald [2009]: The final solution: a genocide, Oxford University Press

Bolotion, Philippe [2011]: After Libya, the question: To protect or depose? August 25, 2011, http://articles.latimes.com/2011/aug/25/opinion/la-oe-bolopion-libyaresponsibility-t20110825

Braeckman, Colette [1994]: Génocide au Rwanda. Paris: Fayart

Braeckman, Colette [2003]: Les nouveaux prédateurs. Politique des puissances en Afrique centrale, Éditions Fayard

Brown, Michael, Freeman, Gary and Miller, Kay [1973]: Passing-By: The United States and Genocide in Burundi, 1972, New York, The Carnegie Endowment for International Peace

Boutroue, Joel [1998]: Missed opportunities- The role of the international community in the return of the Rwandan refugees from Eastern Zaire, July 1994 December 1996, UNHCR Report

Barry Buzan [1983]: People, States \& Fear: The National Security Problem in International Relations, Wheatsheaf Books

Buzan, Barry, Weaver, Ole, de Wilde, Jaap [1998]: Security: A New Framework for Analysis. Lynne Rienner Publisher

Callamard, Agnes [2000]: French Policy in Rwanda, In: Adelman, Howard and Suhrke, Astri [2000]: The Path of a Genocide: The Rwanda Crisis from Uganda to Zaire. Transaction Publishers, New Jersey

Chalk, Frank and Jonassohn, Kurt [1990]: The history and sociology of genocide: analyses and case studies, Yale University Press

Charbonneau, Louis [2012]: Russia U.N. veto on Syria aimed at crushing West's crusade, 8 February, 2012, http://www.reuters.com/article/2012/02/08/us-unrussia-idUSTRE8170BK20120208

Charny, Israel W. [1994]: Toward a generic definition of genocide, University of Pennsylvania Press

Charny, Israel W. [1999]: The Encyclopedia of Genocide, Institute on the Holocaust and Genocide, Jerusalem

Chirot, Daniel and McCauley, Clark [2006]: Why Not Kill Them All? The Logic and Prevention of Mass Murder, Princeton University Press

Chrétien, Jean-Pierre [1995]: Rwanda: Les médias du génocide, Paris, Karthala

Chrétien, Jean-Pierre, Guichaoua, André and Le Jeune, Gabriel [1989]: La Crise d'Aout 1988 au Burundi, Paris, Karthala 
Chrétien, Jean- Pierre [2003]: Afrique des Grands Lacs, 2000 ans d'histoire, Editions Flammarion, Paris

Chrétien, Jean Pierre [2003]: The Great Lakes of Africa: Two Thousand Years of History, translated by Scott Straus. New York: Zone Books

Clapham, Christopher [1998]: Rwanda: The Perils of Peacemaking. Journal of Peace Research, Vol. 35, No. 2, 1998

Clarke, Walter; Herbst, Jeffrey [1996]: Somalia and the future of humanitarian intervention, Foreign Affairs, New York, Mar/Apr 1996

Cobham, Alex [2005]: Causes of Conflict in Sudan: Testing the Black Book, Queen Elizabeth House, University of Oxford, Working Paper Series

Cohen, Roger [2011]: Score One for Interventionism. The New York Times, August 29, 2011

Cros, Marie-France [1994]: "Jean Birara: 'The Belgians and French Could Have Stopped the Killing,", La Libre Belgique, Foreign Broadcast Information Service (FBIS), Central Africa, May 25, 1994.

Csapó Zsuzsanna: Nemzetközi bíróságok fellépése a gyermekeket fegyveres konfliktusok idején védő nemzetközi normák megszegése esetén, http://www.mjsz.uni-miskolc.hu/200901/6_csapozsuzsanna.pdf

Cushman, T. [2003]:Is Genocide Preventable? Some Theoretical Considerations, Journal of Genocide Research, vol. 5, no. 4, pp. 523-542

Davis, R., Majekodunmi, B., \& Smith-Hohn, J. [2008]: Prevention of Genocide and Mass Atrocities and the Responsibility to Protect: Challenges for the UN and the International Community in the 21 st Century, The Responsibility to Protect Occasional Paper Series, International Peace Institute

Day, G., \& Freeman, C. [2005]: Operationalizing the Responsibility to Protect - The Policekeeping Approach, Global Governance, no.11, pp. 139-147

De Lame, Danielle [1996]: Une colline entre mille ou le calme avant la tempête, Transformations et blocages du Rwanda rural, Musée Royal de l'Afrique centrale, Tervuren, Belgique

Des Forges, Alison [1999]: Leave None To Tell The Story: Genocide in Rwanda, New York and Paris: Human Rights Watch and International Federation of Human Rights

de Swaan, Abram [1997]: Widening circles of disidentification. On the Psycho- and Sociogenesis of the Hatred of Distant Strangers; Reflections on Rwanda. Theory, Culture \& Society 1997 (SAGE, London). Vol. 14 (2)

De Waal, Alex [2004]: Famine that kills: Darfur, Sudan, New York, Oxford University Press

De Waal, Alex and Flint, Julie [2005]: Darfur: A short history of a long war, New York: Zed Books

De Waal, Alex and Conley, Bridget [2006]: Reflections on How Genocidal Killings Are Brought to an End, New York, Social Science Research Council

Drost, Pieter Nicolaas[1959]: Genocide; United Nations legislation on international criminal law, A.W. Sythoff 
Dadrian, Vahakn N.[1975]: The Typology of Genocide, International Review of Sociology 5,2

Daniel, Jean: Zaïre la faim fera le travail, Nouvel Observateur, 1996. november 1420

Davis, David Brion [2006]: Inhuman Bondage: The Rise and Fall of Slavery int he New World, New York: Oxford University Press

Dowty, Alan and Gil Loescher [1996]: Refugee Flows as Grounds for International Action. International Security. 21(1):43-71

Dupont, Patrick [1996]: La communauté internationale face à la question de l'intervention humanitaire lors de la rébellion au Kivu (octobre-decembre 1996), In: http://www.ua.ac.be/objs/00110972.pdf

Emizet, Kisangani N.F. [2000]: The massacre of refugees in Congo: a case of UN peacekeeping failure and international law, The Journal of Modern African Studies

Eriksson, John [1996]: The International Response to Conflict and Genocide: Lessons from the Rwanda Experience, Chapter 5: Overall Findings and Recommendations

Fein, Helen: The high cost of not stopping genocide. ISG Newsletter 33

Fein, Helen.[1979]: Accounting for Genocide: National Responses and Jewish Victimization during the Holocaust. New York: Free Press.

Fein, Helen [1984]: Scenarios of Genocide: Models of Genocide and Critical Responses., In Toward the Understanding and Prevention of Genocide: Proceedings of the International Conference on the Holocaust and Genocide, ed. Israel W. Charny. Boulder, CO: Westview Press, 3-31.

Fein, Helen [1993a]: Accounting for Genocide After 1945: Theories and Some Findings., In: International Journal on Group Rights 1, 79-106.old.

Fein, Helen [1993b]: Genocide: A Sociological Perspective. London and Newbury Park, CA: Sage.

Feinstein, L. [2007]: Darfur and Beyond: What Is Needed to Prevent Mass Atrocities, Council on Foreign Relations Special Report, no. 22

Fournet, Caroline [2007]: : The Crime of Destruction and the Law of Genocide Their Impact on Collective Memory, Ashgate Publishing Ltd., USA

Francis, David J. [2006].: Uniting Africa: Building Regional Peace and Security systems, 103.old. Ashgate Publishers

Freeman, M. [1999]: The Role of Institution Building in the Prevention of Genocide", in Smith, R.W.: Genocide: Essays toward Understanding, EarlyWarning and Prevention, New York: Association of Genocide Scholars

Garreton, Oscar [1998]: L'impossible enquête, Le Monde diplomatique, 1998. január

Garreton R.[1996]:,Rapport sur la situation des droits de l'homme au Zaïre conformément à la résolution 1996/77 de la Commission des Droits de 1Homme. Addendum. Mission dans le Kivu septentrional , Nations unies, E/CN.4/1997/6/Add.1 
Gazdik Gyula [2012]: Szíria az ,arab tavasz” sodrában, NKE STRATÉGIAI VÉDELMI KUTATÓKÖZPONT, ELEMZÉSEK - 2012/7

Gellately, Robert; Kiernan, Ben (ed., 2003): The Specter of Genocide: Mass Murder in Historical Perspective. New York, Cambridge University Press

Goldhagen, Daniel Jonah [2009]: Worse Than War: Genocide, Eliminationism, and the Ongoing Assault on Humanity, Public Affairs

Greenland, Jeremy [1976]: Ethnic Discrimination in Rwanda and Burundi, 95-134 in Willem A. Veenhoven (Ed.): Case Studies on Human Rights and Fundamental Freedoms: A World Survey, Vol. 4. The Hague: Martinus Nijhoff

Greenland, Jeremy [1975]: Burundi: the tragic years (an eyewitness account) African Affairs, London, 1975

Grünfeld, Fred; Huijboom, Anke [2007]: The failure to prevent genocide in Rwanda: the role of bystanders. Martinus Nijhoff Publishers, 20. oldal

Guichaoua, André (1995), Les crises politiques au Burundi et au Rwanda (19931994), Université des Sciences et Technologies de Lille/Karthala, Paris

Haász Veronika, Szappanyos Melinda [2012]: Az ENSZ tagállamok emberi jogi helyzetét értékelő egyetemes időszakos felülvizsgálat (UPR). Föld-rész 2011. (4. évf.) 1. szám

Hagengimana, A. [2001]: After Genocide in Rwanda: Social and Psychological Consequences. /25/athanse.html

Haines, Steven; Kassimeris, George, ed. [2010], Chapter 18, Humanitarian Intervention: Genocide, Crimes against Humanity and the Use of Force, The Ashgate research companion to modern warfare, Burlington, VT: Ashgate Publishing Ltd

Hamburg, David [2010]: Preventing genocide, Practical steps toward early detection and effective action, Paradigm Publishers, London

Hamilton, R.J. [2006]: The Responsibility to Protect: From Document to Doctrine But What of Implementation? Harvard Human Rights Journal, no.19, pp. 289-297

Haraszti Margit Katalin [2008]: A kínzás és az embertelen vagy megalázó bánásmód és büntetések tilalma az ENSZ és az Európa Tanács legfontosabb dokumentumaiban, valamint az állampolgári jogok országgyülési biztosának tevékenységében. ACTA HUMANA 19. évfolyam, 2008. 3. szám

Harff, Barbara [1987]: “The Etiology of Genocide.” In The Age of Genocide, ed. Michael N. Dobkowski and Isador Wallimann. Westport, CT: Greenwood Press, 41-59.old.

Harff, Barbara [1992]: Recognizing Genocides and Politicides., In Genocide Watch, ed. Helen Fein. New Haven, CT: Yale University Press, 27-41.old.

Harff, Barbara and Gurr, Ted [1994]: Ethnic conflict in World Politics, Westview Press

Harff, Barbara [2003]: No Lessons Learned from the Holocaust? Assessing Risks of Genocide and Political Mass Murder since 1955, American Political Science Review, February 2003 
Harff, Barbara [2009]: Recognizing Genocides and Politicides, In: Genocide Studies Reader, Bartrop, Paul R.; Totten (ed.):, Samuel, Routledge

Heffernan, John, MPA; Leaning, Jennifer, MD, SMH [2006]: Darfur - Assault on Survival, January 2006. http://www.physiciansforhumanrights.org /library/reports/darfur-assault-on-survival-report-sudan-2006.html

Hilberg, Raul [1985]: The Destruction of the European Jews, Holmes and Meier

Hirad Abtahi, Paula Webb [2008]: The Genocide Convention: The Travaux Préparatoires, Martinus Nijhoff Publishers

Hoffmann Tamás [2006]: Egy előre meghozott ítélet krónikája? A Népirtás büntettének megelőzéséről és megbüntetéséről szóló egyezmény alkalmazása (Bosznia és Hercegovina kontra Szerbia és Montenegró) ügy a hágai Nemzetközi Bíróság előtt, Kül-Világ, III. évfolyam. 2006/2

Homans, Charles [2011]: Responsibility to Protect: A Short History. Foreign Policy, November 2011, http://www.foreignpolicy.com/articles/2011/10/11/responsibility _to_protect_a_short_history?page=0,

Howe, Marvine [1972]: Slaughter in Burundi, The New York Times

Horowitz, Irving Louis [1976]: Genocide: State power and mass murder. New Brunswick, NJ: Transaction Books.

Hoyt, Michael [1972]: US Embassy Cables from Bujumbura to State Department. Unpublished materials available from the University of Florida Libraries, Gainesville

Hubert, Don; Weiss, Thomas G. [2001] : The Responsibility to protect: Research, bibliography, background Supplementary Volume to the Report of the International Commission on Intervention and State Sovereignty

Huttenbach, Henry R.[1988]: Locating the Holocaust on the Genocide Spectrum: Towards a Methodology of Definition and Categorization, Holocaust and Genocide Studies 3:3

Inazumi, Mitsue [2005]: Universal jursidiction under international law: Expansion of national jurisdiction for Prosecuting Serious Crimes under International Law, Intersentia

International Commission on Intervention and State Sovereignty [2001]: The Responsibility to Protect. Ottawa, Canada, the International Development Research Centre

Jonassohn, Kurt; Björnson, Karin Solveig[1998]: Genocide and gross human rights violations in comparative perspective, Transaction Publishers

Jones, Adam [2010]: Genocide: A Comprehensive Introduction. Second Edition, Routledge/Taylor and Francis Publishers

Kalayjian, A. S., Shahinian, S. P., Gergerian, E. L., \& Saraydarian, L. [1996]: Coping with Ottoman Turkish genocide: An exploration of the experience of Armenian survivors. Journal of Traumatic Stress, 9(1), 87-97

Kapuscinski, Ryszard [2000]: Ében. Széphalom Könyvműhely, Budapest

Karacs, Imre [1996]: Zaire Military Option Ruled Out, The Independent, 1996. november 25 . 
Katz, Steven T.[1994]: The Holocaust in Historical Context: The holocaust and mass death before the modern age, Oxford University Press

Kempf, Isabell [2012]: Bridging the Great Lakes, Implementing the human rights dimension of the International Conference on the Great Lakes Region, In: Regional dimensions of Conflict in the Great Lakes, ISS Workshop Report, 2012

Kiraranganiya, B., F. [1985]: La vérité sur le Burundi, Sherbrook, Canada, Editions Naaman

Kirs Eszter [2003]: A népirtás büntettének nemzetközi jogi szabályozása, Miskolci Egyetem, ÁJK, Deák Ferenc Doktori Iskola, Doktoranduszok Fóruma, 2003. november 6. Novotni Alapítvány, Miskolc

Kirs Eszter [2003]: A népirtás büntettének nemzetközi jogi szabályozása. Miskolci Egyetem, ÁJK, Deák Ferenc Doktori Iskola, Doktoranduszok Fóruma, 2003. november 6. Novotni Alapítvány, Miskolc, 2003

Kondorosi Ferenc [2008]: A világ végveszélyben? A nemzetközi jog új kérdései, Budapest, Magyar Közlöny Lap- és Könyvkiadó

Kuper, Leo [1981]: Genocide: Its Political Use in the Twentieth Century. New Haven, CT: Yale University Press

Kuper, Leo [1985]: The Prevention of Genocide ,New Haven and London: Yale University Press

Kuperman, Alan J. [2004]: Provoking genocide : a revised history of the Rwandan Patriotic Front, in Journal of genocide research, 6 (1)

Krueger, Robert és Krueger, Kathleen Tobin [2007]: From Bloodshed to Hope in Burundi. University of Texas Press

Lakatos István [2007]: Az ENSZ Emberi Jogi Tanácsa: Vágyak és realitások. Fundamentum, 2007/1. szám, http://157.181.181.13/dokuk/07-01-06.pdf

Lamb, Scott [2005]: Genocide Since 1945, Never Again? Spiegel Online International, http://www.spiegel.de/international/0,1518,338612,00.html

Lamm Vanda [2003]: A délszláv háború újabb felvonása a Nemzetközi Bíróság előtt. A NATO bombázások ügye a Bíróság előtt, http://www.balkancenter.hu/pdf/elemzes/lammv.pdf

Le Fevre, Cervini, Enzo Maria, Lakatos, István [2009]: The construction of a global architecture for the prevention of genocide and mass atrocities, 149-153.old. In: Politorbis No.47.-

Genocide

Prevention, http://www.eda.admin.ch/etc/medialib/downloads/edazen/doc/publi/publi2.Par.00 95.File.tmp/Politorbis\%2047\%20-\%20Genocide\%20Prevention.pdf

Lehrer, Jonah [2007]: The Psychology of Genocide In: The Frontal Cortex, April 13, 2007, http://scienceblogs.com/cortex/2007/04/the_psychology_of_genocide.php

Lemarchand, René [1970]: Rwanda and Burundi. London and New York: Pall Mall Press and Frederick Praeger.

Lemarchand, René [1974]: Selective Genocide in Burundi, London, Minority Rights Group

Lemarchand, René [1985]: Rwanda and Burundi, London, Pall Mall Press 
Lemarchand, René [1996]: Burundi: Ethnic conflict and genocide, Cambridge University Press

Lemarchand, René [1998]: Genocide in the Great Lakes: Which Genocide? Whose Genocide? African Studies Review, Vol. 41, No. 1

Lemarchand, René [2002]:Le génocide de 1972 au Burundi: Les silences de l'histoire, pp. 551-567., Cahiers d'Études Africaines, No. 167., XLII.-3.

Lemarchand, René [2009]: The Dynamics of Violence in Central Africa. Philadelphia: University of Pennsylvania Press

Lemkin, Raphael [1994]: Axis Rule in Occupied Europe: Laws of Occupation Analysis of Government - Proposals for Redress, Washington, D.C.: Carnegie Endowment for International Peace

Levene, Mark [2005]: Genocide in the Age of the Nation State: The rise of the West and the coming of genocide, I.B. Tauris and Co. Publishers, London

Letgers, Lyman [1984]: The Soviet Gulag: Is It Genocide?, In: Charny, Israel (ed.): Toward the Understanding and Prevention of Genocide: Proceedings of the International Conference on the Holocaust and Genocide, Boulder, Westview Press

Lyons, Leonard [1947]: Washington Post, 1947 January 30, Loose-Leaf Notebook, Page 9, Washington, D.C. (ProQuest Historical Newspapers)

Lyons, Leonard [1947]: Salt Lake Tribune, Lyons Den, Page 8, Column 3, Salt Lake City. (NewspaperArchive)

Malkki, Liisa [1995]: Purity and Exile: Transformations in Historical-National Consciousness Among Hutu Refugees in Tanzania, Chicago, University of Chicago Press

Mamdani, Mahmoud (2001). When Victims Become Killers: Colonialism, Nativism, and the Genocide in Rwanda. Princeton, NJ: Princeton University Press

Mamdani, Mahmood [2004]: How can we name the Darfur Crisis? Some Preliminary Thoughts, Black Commentary

Mamdani, Mahmood [2007]: The Politics of Naming Genocide, Civil War, Insurgency, London Review of Books

Mathieu, Paul and Tsongo, Mafikiri [1999] : Enjeux fonciers, deplacement de population et escalades conflictuelles (1930-1995) In: P. Mathieu and J. C. Willame (eds.), Conflits et guerres au Kivu et dans la région des grands lacs (Paris, 1999), 20-25.old.

Matus János [2005]: A biztonság és a védelem problémái a változó nemzetközi rendszerben, Hadtudomány, 2005/4.

Matus János [2005]: A jövő árnyéka. Nemzetközi hatások biztonságunkra és jólétünkre, A Pesti Csoport Kiadó, Budapest

McKinley, James Jr: As Fighting in Zaire Spreads, Rwanda Rules Out Talks. The New York Times, October 29, 1996

Menon, Rajan [2012]: The Russia-China Veto: What Next for Syria?, 6 February, 2012.

http://www.huffingtonpost.com/rajan-menon/syria-veto-unitednations_b_1256322.html 
Midlarsky, Manus I.[2005]: The killing trap: genocide in the twentieth century, Cambridge University Press

Millwood, David [1996]: The International Response to Conflict and Genocide: Lessons from the Rwanda Experience, Steering Committee on the Joint Evaluation of Emergency Assistance to Rwanda

Mohyeldin, Alman [2012]: Russia, China veto UN rebuke of Syrian president, Worldnews on msnbc.com, February 4, 2012, http://worldnews.msnbc.msn.com/_news/2012/02/04/10317567-russia-china-vetoun-rebuke-of-syrian-president

Munyarugerero, François- Xavier [2003]: Réseaux, pouvoirs, oppositions, La compétition politique au Rwanda Editions L'harmattan, Paris

Munzihirwa, Christophe [2007]: Lettere e appelli dal Congo, EMI (collana Vita di missione)

Murithi, T., \& Mpyisi, K. [2007]: Conflict Prevention and the 'Responsibility to Protect' in Africa?, African Security Review vol 16, no. 3.

Mwakikagile, Godfrey [2012]: Identity Politics and Ethnic Conflicts in Rwanda and Burundi: A Comparative Study, Intercontinental Books

Ndarusigiye, Mevin, Mayoya, Marie [2000]: Burundi: when the pie is too small: handbook of ethnic conflicts and resource management, Intercontinental Books

Nsanze, Augustin [2003]: Le Burundi contemporain: L'état-nation en question, Paris: L'Harmattan

Nsanze, Augustín [2003]: Le Burundi contemporain: L'état-nation en question. Paris, L'Harmattan

Pomfret, John [1997]: Rwandans Led Revolt in Congo, Washington Post, July 9, 1997

Porter, Jack Nusan [1982]: Genocide and Human Rights: A Global Anthology, University Press Of America

Posen, Barry [1996]: Military Responses to Refugee Disasters. International Security. 21(1):72-111.

Power, Samantha [2001a]: Bystanders to genocide. http://www.theatlantic.com /nagazine/archive/2001/09/bystanders-to-genocide/304571/

Power, Samantha [2001b]: A Problem from Hell. New Republic Book

Power, Samantha [2003]: A Problem from Hell:America and the Age of Genocide, HarperCollins

Presidents of Burundi: Melchior Ndadaye, Pierre Nkurunziza, Pierre Buyoya, Domitien Ndayizeye, Cyprien Ntaryamira, Michel Micombero, General Books, 2010

Prunier, Gérard [1989]: Les Ethnies ont une histoire (ed. with Jean-Pierre Chrétien), Paris: Karthala

Prunier, Gérard [1995]: The Rwanda Crisis: History of a Genocide, Columbia University Press 
Prunier, Gérard [1998. július]: Power struggle in Kivu- Congolese flashpoint. http://mondediplo.com/1998/07/08kivu

Prunier, Gérard [2002]: Sudan: irreconcilable differences, Le Monde diplomatique, December 2002

Prunier, Gérard [2006]: Did Somebody Say Genocide?: Gérard Prunier on Darfur, Harper's Magazine, August 2006

Prunier, Gérard [2009]: Africa's World War: Congo, the Rwandan Genocide, and the Making of Continental Catastrophe, Oxford University Press

Prunier, Gérard [2009]: From Genocide to Continental War: The "Congolese" Conflict and the Crisis of Contemporary Africa, C. Hurst \& Co

Reeves, Eric [2007]:Darfur Betrayed Again: The UN/AU Hybrid Force Steadily Weakens, augusztus 24, www.sudareeves.org/article182.html

Reeves, Eric [2004]: Ethnic Cleansing in Darfur: Systematic, Ethnically Based Denial of Humanitarian Aid Is No Context for a Sustainable Agreement in Sudan, SPLMToday.com, december 30.

Republic of Rwanda: Ministry of Foreign Affairs and Cooperation [2010]: Official Governemnt of Rwanda Comments on the Draft UN Mapping Report on the DRC, 11.old.

Reyntjens, Filip [1985]: Pouvoir et droit au Rwanda, Droit Public et Evolution politique, 1916- 1973, Musée Royal de l'Afrique Centrale, Tervuren, Belgique

Reyntjens, Filip [1994]: L'Afrique des grands- lacs en crise, Rwanda, Burundi: 1988- 1994, Editions Karthala, Paris

Reyntjens, F., Marysse S. [1996]:Conflits au Kivu: antécédents et enjeux,7. Anvers, Centre d'étude de la région des Grands Lacs d'Afrique, décembre 1996.

Reyntjens, Filip [2009]: The Great African War: Congo and Regional Geopolitics, 1996-2006. Cambridge: Cambridge UP, 2009

Roberts, Andrews [1996]: Zaire: A Problem for France Alone, The Sunday Times, 1996. november 10.

Rombouts, Heidy [2004]: Victim Organisations and the Politics of Reparation: A Case Study on Rwanda, Intersentiua Publishers

Ruhashyankiko, Nicodème[1978]:Study on the Question of the Prevention and Punishment of the Crime of Genocide, United Nations, Economic and Social Council, Commission on Human Rights, Sub-Commission on Prevention of Discrimination and Protection of Minorities, E/CN. 4/Sub. 2/ 416, 4 July 1978

Rummel, R.J. [1997a]: Power kills: Democracy as a Method of Nonviolence. New Brunswick, N.J.Transaction Publishers

Rummel, R.J.[1997b]: Death by Government, Transaction Publishers

Sántha Ferenc [2007]: A népirtás büncselekményének néhány problematikus kérdéséről. Bünügyi Tudományi Közlemények 8: Tanulmányok Dr. Dr. H.C. Horváth Tibor Professor Emeritus 80. születésnapja tiszteletére, Miskolc

Sántha Ferenc [2008]: Az emberiesség elleni bűncselekmények. Miskolci Jogi Szemle, 3. évfolyam (2008) 1. szám 
Saleh, Yasmine; Samir, Ayman [2011]: Arab League suspends Syria as global pressure rises. 12 November, 2011, http://www.reuters.com/article/2011/11/12/usarabs-syria-idUSTRE7AB0CP20111112

Salehyan, Idean [2007]: The Externalities of Civil Strife: Refugees as a Source of International Conflict. http://www.cas.unt.edu/ idean/RefugeesWar.pdf

Schabas, William [2000]: Genocide in international law- The crime of crimes, The Press Syndicate of the University of Cambridge, United Kingdom

Schabas, William [2003]: Ethnic Cleansing and Genocide: Similarities and Distinctions. European Yearbook of Minority Issues, Vol.3., 2003/4, Martinus Nijhoff Publishers

Schabas, William [2006]: The UN International Criminal Tribunals: The Former Yugoslavia, Rwanda and Sierra Leone, Cambridge, Cambridge University Press

Schabas, William [2007]: Preventing the Odious Scourge: The United Nations and the Prevention of Genocide. International Journal on Minority and Group Rights 14

Schimmer, Russell: GSP Working Paper No. 36, Tracking the Genocide in Darfur: Population Displacement as Recorded by Remote Sensing,

Schiraldi, G. [2001]:The post-traumatic stress disorder sourcebook. Los Angeles: Lowell House

Sémelin, Jacques [2007]: Purify and Destroy: The Political Uses of Massacre and Genocide, Columbia University Press, New York

Shany, Yuval[2009]: The Road to the Genocide Convention and beyond, In: The UN Genocide Convention- A commentary, Edited by: Paola Gaeta, Oxford University Press, 2009

Shaw, Martin [2007]: What is Genocide? Polity Press

Slovic, Paul [2007a]: Numbed by numbers, Never again? Its not lack of compassion that holds us back from stopping genocide, http://www.foreignpolicy.com/articles/2007/03/12/numbed_by_numbers

Slovic, Paul [2007b]: If I look at the mass I will never act: Psychic numbing and genocide, In: Judgment and Decision Making, vol. 2, no. 2, April 2007, pp. 79-95.

Slovic, Paul [2010]: The More Who Die, the Less We Care, In: Michel-Kerjan, Erwann; Slovic, Paul [2010]: The Irrational Economist, PublicAffairs, 30-41.old.

Stanton, Gregory [1998]: The eight stages of genocide, Working Paper (GS 01) of the Yale Program in Genocide Studies in 1998, http://www.genocidewatch.org/images/8StagesBriefingpaper.pdf

Stanton, Gregory H.: Proving Genocide in Darfur: The Atrocities Documentation Project and Resistance to its Findings, http://www.genocidewatch.org/provinggenocidedarfur.html

Staub, Ervin [1989]: The Roots of Evil: The Origins of Genocide and Other Group Violence. Cambridge, UK: Cambridge University Press

Staub, Ervin [1999]: The Origins and Prevention of Genocide, Mass Killing, and Other Collective Violence, Peace and Conflict: Journal of Peace Psychology, vol. 5, no.4., pp. 303-336. 
Sterling, Joe; Maktabi, Rima és Fahmy, Mohamed Fadel: Syrian opposition cites regime 'acts of genocide' December 21, 2011, http://articles.cnn.com/2011-1221/middleeast/world_meast_syria-unrest_1_idlib-syrian-revolution-syriannational-council?_s=PM:MIDDLEEAST

Strauss, Scott [2006]: The Order of Genocide, Race, Power and War in Rwanda. Ithaca and London: Cornell University Press

Straus, Scott [2007]: Second Generation Comparative Research on Genocide, World Politics 59

Thakur, Ramesh: The model of a mediocre secretary general [2009.10.25.], Ottawa Citizen. http://www.cigionline.org/articles/2009/09/model-mediocre-secretarygeneral

Szabó Loránd [2008]: Kongói kaleidoszkóp 1998-2008: a hatalmi erőtér változásai. Külügyi Szemle, 2008. tél

Szabó Loránd: Kongó - válsággóc Kelet és Nyugat között • Vázlat a Zaire/Kongói Demokratikus Köztársaság 1995-2005 címü előadás írott változatához. http://www.afrikatanulmanyok.hu /application/essay/790_1.pdf

Tanner, Fred és Stedman, S.J. [2003]: Refugee Manipulation. The Brookings Institution

Tarrósy István [2011]: Kelet-Afrika a fejlődés útján: A Kelet-afrikai Közösség és tagállamai közelebbröl. Pécs: Publikon Kiadó, 2011.

Teltsch, Kathleen [1972]: Killings Go on in Burundi, július 20., The New York Times

Thompson, John L. and Gail A. Quets [1987]: Genocide and Social Conflict: A Partial Theory and Comparison,' in Louis Kriesberg (ed.), Research in Social Movements, Conflicts and Change. Vol. 12. Greenwood, CN, JAI Press

T. Horváth Attila [2004]: Ruanda 94: Egy krízis történelmi háttere. Kül-Világ, 2004/2. szám, I. évfolyam

T. Horváth Attila (2008): Agathe Uwilingiyimana - Ruanda mártír miniszterelnöke. Afrika Tanulmányok folyóirat. II. évfolyam, 1. szám

Totten, Samuel; Jacobs, Steven Leonard [eds, 2002]: Pioneers of Genocide Studies, New Brunswick (NJ): Transaction Publishers

Totten, Samuel [2006]: The U.S. Investigation into the Darfur Crisis and Its Determination of Genocide: An Analysis in Totten, Samuel and Markusen, Erik: Genocide in Darfur: Documenting Atrocities in the Sudan, New York, Routledge

Totten, Samuel; Parsons, William S.[2009]: Century of genocide: critical essays and eyewitness accounts, Routledge

Tottenham, Samuel; Bartrop, Paul R. [2009].: The Genocide Studies Reader, Routledge, 2009

Uvin, Peter [1998]: Aiding Violence: The Development Enterprise in Rwanda, Kumarian Press. The Role of Ecological Scarcity

Uvin, Peter [1999]: Ethnicity and Power in Burundi and Rwanda: Different Paths to Mass Violence, Comparative Politics 
Vida László [2003]: Az ítélet: Éhhalál, http://www.mult-kor.hu/cikk.php?id=5461

Vincent, M., \& Le Fevre Cervini, E. [2008]: Preventing Genocide and Mass Atrocities: Our Responsibility to Prevent, Madariaga Report

Viret, Emmanuel [2010]: Chronologie du Rwanda (1867- 1994), Encyclopédie en ligne des violences de masse. http://www.massviolence.org/Chronologie-duRwanda-1867-1994

Vlassenroot, Koen [2002]: Citizenship, Identity Formation \& Conflict in South Kivu: The Case of the Banyamulenge, Review of African Political Economy, Vol. 29 No.93/94 (Sep/Dec 2002)

Waller, James [2007]: Becoming evil: how ordinary people commit genocide and mass killing, Oxford University Press

Wallimann, Isidor and Dobkowski, Michael N.[1987]: Genocide and the Modern Age: Etiology and Case Studies of Mass Death, Greenwood Press, Westport

Watt, Nigel [2008]: Burundi: Biography of a Small African Country. Columbia University Press

Weiner, Myron [1996]: Bad neighbors, bad neighborhoods: an inquiry into the conditions for refugee flows. Department of Political Science, MIT

Weitz, Eric D.[2003]: A century of genocide: utopias of race and nation, Princeton University Press

Whitaker, Benjamin [1985]: Revised and Updated Report on the Question of the Prevention and Punishment of the Crime of Genocide, United Nations, Economic and Social Council, Commission on Human Rights, Sub-Commission on Prevention of Discrimination and Protection of Minorities, E/CN.4/Sub. 2/1985/6, 2 July 1985.

Woocher [2008]: Preventing Violent Conflict: Assessing Progress, Meeting Challenges. United States Institute of Peace, Special Report

\section{Felhasznált dokumentumok}

1955.évi 16. törvényerejü rendelet, http://net.jogtar.hu/jr/gen/hjegy_doc.cgi?docid=95500016.TVR

Akayesu (ICTR-96-4-T), http://www1.umn.edu/humanrts/instree/ICTR/AKAYESU_ICTR-964/Sentence_ICTR-96-4-T.html

Krstic ( IT-98-33-A), http://sim.law.uu.nl/sim/caselaw/tribunalen.nsf/a7a6d0b53b46ca55c12571b5003d 409a/3a0b3c91b14fe8e3c12571fe004c8b10?OpenDocument

ICC-02/05-01/09, http://www.icccpi.int/en_menus/icc/situations\%20and\%20cases/situations/situation\%20icc\%200 205/related\%20cases/icc02050109/Pages/icc02050109.aspx

ICC Prosecutor: Gaddafi used his absolute authority to commit crimes in Libya, ICC-CPI-20110516-PR667, http://www.icccpi.int/en_menus/icc/situations\%20and\%20cases/situations/icc0111/press\%20rele ases/Pages/pr667.aspx 
Human Rights Council resolution 5/1 of 18 June 2007, Annex, I. Fejezet, D., 2., 18. (a), (d) pont

Report on the Fourth Special Session of the Human Rights Council, UN Doc. A/HRC/4/5, http://daccess-ddsny.un.org/doc/UNDOC/GEN/G07/110/36/PDF/G0711036.pdf?OpenElement

Human Rights Watch [2009]: Soldiers Who Rape, Commanders Who Condone: Sexual Violence and Military Reform in the Democratic Republic of Congo. New York: Human Rights Watch

Human Rights Watch [2010]: UN releases Congo genocide report. http://www.hrw.org/news /2010/10/01/dr-congo-un-report-exposes-grave-crimes

Human Rights Watch [2011]: Justice Compromised: The Legacy of Rwanda's Community-Based Gacaca Courts. http://www.hrw.org/sites/default/files/reports /rwanda0511webwcover.pdf

International Crisis Group [1999]: Burundian Refugees in Tanzania: A Key Factor in the Burundi Peace Process. ICG Central Africa Report N 12, 25 November 1999

International Crisis Group [2007]: Congo: Bringing Peace to North Kivu. Crisis Group Africa Report N¹33, 31 October 2007

MONUC Facts and Figures. http://www.un.org/en/peacekeeping/missions/monuc/facts.shtml

Organization of African Union [2000]: Rapport sur le génocide au Rwanda. http://www.africa-union.org/official_documents/reports/OUA-Rapport\%20sur $\% 201$ e\%20genocide\%20au\%20Rwanda.pdf

Organisation Interafricaine des Juristes: La crise humanitaire dans l'Est du Zaire, 1997

Rome Statute of the International Criminal Court, Article 6: The crime of genocide. http://untreaty.un.org/cod/icc/statute/romefra.htm

S/RES/1078 (1996), 1996. november 9., http://www1.umn.edu/humanrts/resolutions/SC96/1078SC96.html

S/RES/1080 (1996), 1996.november 15., http://www1.umn.edu/humanrts/resolutions/SC96/1080SC96.html

S/1999/1257, http://www.securitycouncilreport.org/atf/cf/\%7B65BFCF9B-6D274E9C-8CD3-CF6E4FF96FF9\%7D/POC\%20S19991257.pdf

Security Council, statement, December 15, 1994, Forrás: http://web.mit.edu/cis/www/migration/pubs/rrwp/1_missedop.pdf

TPIR, ICTR-96-7-I, 1999, http://www.unictr.org/tabid/128/Default.aspx?id=10\&mnid=4

UN Doc. S/RES/827(1993), http://www1.umn.edu/humanrts/peace/docs/scres827.html

UN Doc. S/RES/955(1994), http://www1.umn.edu/humanrts/peace/docs/scres955.html

UN News Centre [2003]: As Refugees Into Chad from Sudan, UN Announces Plans for Safer Camps, december 23., New York, United Nations 
United Nations [2004]: Sudan: World's Worst Humanitarian Crisis- Press Release, március 22. , New York

UN Department of Humanitarian Affairs [1996]: Integrated Regional Information Network: Weekly Roundup of Main Events in the Great Lakes Region, No.s 25 27, 1996. november 15-18., No. 34., 1996. november 3-10.

UN Millennium Report 2000, Chapter 3: Freedom from fear, http://www.un.org/millennium/sg/report/ch3.pdf

UNHCR, Syria Regional Refugee Response, http://data.unhcr.org/syrianrefugees/regional.php

UNHCR Publications [2000]: The State of The World's Refugees 2000: Fifty Years of Humanitarian Action. Chapter 10: The Rwandan genocide and its aftermath. http://www.unhcr.org/3ebf9bb60.html

UNHCR [2007]: Group Resettlement of "1972 Burundians" from Tanzania. Burundi Fact Sheet. http://www.unrefugees.org/atf/cf/\%7BD2F991C5-A4FB-4767-921FA9452B12D742\%7D/Burundifactsheet.pdf

UNHCR [2010]: DRC: Mapping Human Rights Violations 1993-2003 http://www.ohchr.org /Documents/Countries/ZR/DRC_MAPPING _REPORT_FINAL_EN.pdf

\section{Weboldalak, újságcikkek}

A magyar ENSZ Társaság honlapja

A magyar Külügyminisztérium honlapja

http://www.antislavery.org

http://www.aegistrust.org

http://au.int/en

http://www.aljazeera.com

http://www.bbc.co.uk/news/

http://www.brookings.edu

http://www.china.org.cn

http://www.clarku.edu/departments/holocaust/, Strassler Family Center for Holocaust and Genocide Studies, Clark University

http://www.consilium.europa.eu

http://www.euronews.net

http://www.france24.com/en/

www.genocideprevention.eu

http://www.genocideprevention.eu/About.html

http://www.genocideprevention.eu/Initiatives.html

http://www.genocideprevention.eu/Research_and_Cooperation.html

http://www.genprev.net

http://www.genprev.net/wp-content/uploads/2012/05/First-Booklet-English-and-

French.pdf

http://globalr2p.org

http://www.icc-cpi.int

www.icc-cpi.int/ The Court Today

http://www.icj-cij.org

www.icj-cij.org/docket/files/91/13685.pdf 
https://icglr.org

https://icglr.org/spip.php?article1

https://icglr.org/spip.php?article2

https://icglr.org/IMG/pdf/Pact_on_Security_Stability_Development-S.pdf

http://www.kulugyminiszterium.hu/kum/hu/bal/Kulpolitikank/emberi_jogok_vedelm

e/bp_nepirtas_megelozesi_kozpont/

http://www.nepad.org

http://www.hrw.org/news/2008/04/25/q-crisis-darfur

http://www.icty.org

http://www.massatrocitiestaskforce.eu

http://www.ohchr.org/EN/NewsEvents/Pages/DisplayNews.aspx?

NewsID=8476\&LangID=E

http://www2.ohchr.org

http://www2.ohchr.org/english/law/cat.htm

http://www2.ohchr.org/english/law/cat-one.htm

http://www.ohchr.org

http://www.origo.hu/nagyvilag /

http://physiciansforhumanrights.org

http://www.podfeed.net

www.preventgenocide.org/

www.preventgenocide.org/prevent/UNdocs/KofiAnnanStockholmGenocideProposal s26Jan2004.htm

http://www.reuters.com/

http://www.responsibilitytoprotect.org

http://www.responsibilitytoprotect.org/index.php/crises/crisis-in-drc, [2013.01.31.]

http://treaties.un.org

http://www.un.org/ga/search/view_doc.asp?symbol=S/RES/1097(1997)

http://www.un.org/en/preventgenocide/adviser/

http://www.un.org/preventgenocide/rwanda/

http://www.un.org/documents/ga/res/1/ares1.htm

http://www.unhcr.org

http://www.unis.unvienna.org/pdf/UN-Darfur_fact_sheet.pdf

http://untreaty.un.org/cod/icc/statute/romefra.htm

http://www.un.org/secureworld

http://www.un.org/largerfreedom/

http://www.un.org/News/

http://www.thedailybeast.com/newsweek/2007/11/07/dueling-over-darfur.html

http://www.un.org/News/Press/docs/2011/sc10200.doc.htm

http://www.un.org/News/Press/docs/2011/sc10215.doc.htm

http://www.un.org/News/Press/docs/2011/sc10200.doc.htm

http://www.un.org/News/Press/docs/2011/sgsm13454.doc.htm

http://www.un.org/ictr/statute.html

http://www.ushmm.org/, United States Holocaust Memorial Museum,

http://www.yale.edu/cgp/ Cambodian Genocide Program, Yale University

Alison des Forges emberjogi aktivista vallomása 1998. május 5-én a e Subcommittee on International Operations and Human Rights előtt,

http://www.ess.uwe.ac.uk/Rwanda/Rwanda2.htm\#N_3 
AP Enterprise: Questions raised on Congo slaughter, October 10, 2010 http://www.foxnews.com/world/2010/10/10/ap-enterprise-questions-raised-congoslaughter/

Assessments of the President and the Prosecutor of the International Criminal Tribunal for Rwanda on the implementation of the completion strategy of the Tribunal. http://www.unictr.org/Portals/0/English/FactSheets/Completion_St/S2012-349.pdf

Amanpour: Looking back at Rwanda genocide, April 06, 2004.

http://articles.cnn.com/2004-04-06/world/rwanda.amanpour_1_rwanda-genocidehutu-extremists-somalia?_s=PM:WORL

BBC World News, Africa: Rwanda 'gacaca' genocide courts finish work, 18 June 2012, http://www.bbc.co.uk/news/world-africa-18490348

Belgium's reaction to the Burundi Situation, Memorandum az elnöknek Henry Kissingertöl. September 29, 1972. http://20012009.state.gov/documents/organization/53886.pdf

The Christian Science Monitor- Max Delany: Sarkozy admits France made 'serious errors' over Rwanda genocide, 2010.február 25. http://www.csmonitor.com/World/Africa/2010/0225/Sarkozy-admits-Francemade-serious-errors-over-Rwanda-genocide

The Economist, Obituary of Laurent Kabila, 2001. január 18., http://www.economist.com/node/481974

The Economist, The uses and abuses of the G-word, 2012. június 2., http://www.economist.com/node/18772664

Eliot memoranduma Kissingernek, Washington, September 24, 1972, Forrás: National Archives, Nixon Presidential Materials, NSC Files, Box 735, Country Files, Africa, Burundi, Vol. I. Confidential

Improving the capacity of the United Nations for peace-keeping of 14 March 1994. (S/26450).

International Herald Tribune, US weighs troop use in Zaire crisis, 1996. november 6.

International Herald Tribune, Canada Agrees to Lead Military Force in Zaire, 1996. november 12 .

International Herald Tribune, Zaire: Clinton Agrees to Contribute Troops to Mission, 1996. november 14.

Libération, Zaire: le forcing français, 1996. november 7

Libération, Massacres au Zaire:Le témoignage qui réveille les Occidentaux, 1997. március 10.

Le Monde, Les Hutu réfugiés dans les camps du Zaïre regagnent massivement le Rwanda, 1996. november 18.

Madeleine Albright tanúvallomása a Foreign Operations Subcommittee of the House Appropriations Committee elött, 1994.05.05.

Le Nouvel Observateur, 1996. október 7-13. Le souvenir amer de Turquoise 
Report of the Independent Inquiry into the actions of the United Nations during the 1994 genocide in Rwanda

Reuters, 1994.december 6.

Solidarité Internationale pour les Réfugiés Rwandais: Le Non-Dit sur les Massacres au Rwanda, vol. 2, January 1995, és vol. 3, July 1995

Sénat de Belgique:"Rapport", 6 décembre 1997.

Le Soir, 1967. szeptember 18.

Stephen W. Smith oknyomozó újságíró becslése a Libération c. újság 1996 februári számában. In: London Review of Books, bVol. 33 No. 6

Ábrák forrása:

http://education.nationalgeographic.com/education/mapping/outlinemap/?map=Africa\&ar_a=1

http://education.nationalgeographic.com/education/mapping/outlinemap/?map=Burundi\&ar_a=1

http://education.nationalgeographic.com/education/mapping/outlinemap/?map=Rwanda\&ar_a $=1$

http://education.nationalgeographic.com/education/mapping/outlinemap/?map=Dem_Rep_Congo\&ar_a=1

HRW [2009]: Soldiers Who Rape, Commanders Who Condone: Sexual Violence and Military Reform in the Democratic Republic of Congo. New York: Human Rights Watch

http://www.hrw.org/sites/default/files/reports/drc0709web.pdf

United Nations (2004): Map No. 4004.1, UN Department of Peacekeeping Operations, Cartographic Section

http://gijigya.files.wordpress.com/2012/04/great-lakes-africa-map-mediumthumbpdf2.png

DRC: Mapping Human Rights Violations 1993-2003. http://www.ohchr.org/Documents/Countries/ZR/DRC_MAPPING_REPORT_FIN AL_EN.pdf

Policy Penguin (2011): Evaluating the need for strategy: USAID in Rwanda postgenocide, http://policypenguin.blogspot.hu/2011/11/evaluating-need-for-strategyusaid-in.html

Conference Secretariat of the International Conference on the Great Lakes Region (2012) alapján. http://www.genprev.net/wp-content/uploads/2012/05/FirstBooklet-English-and-French.pdf 